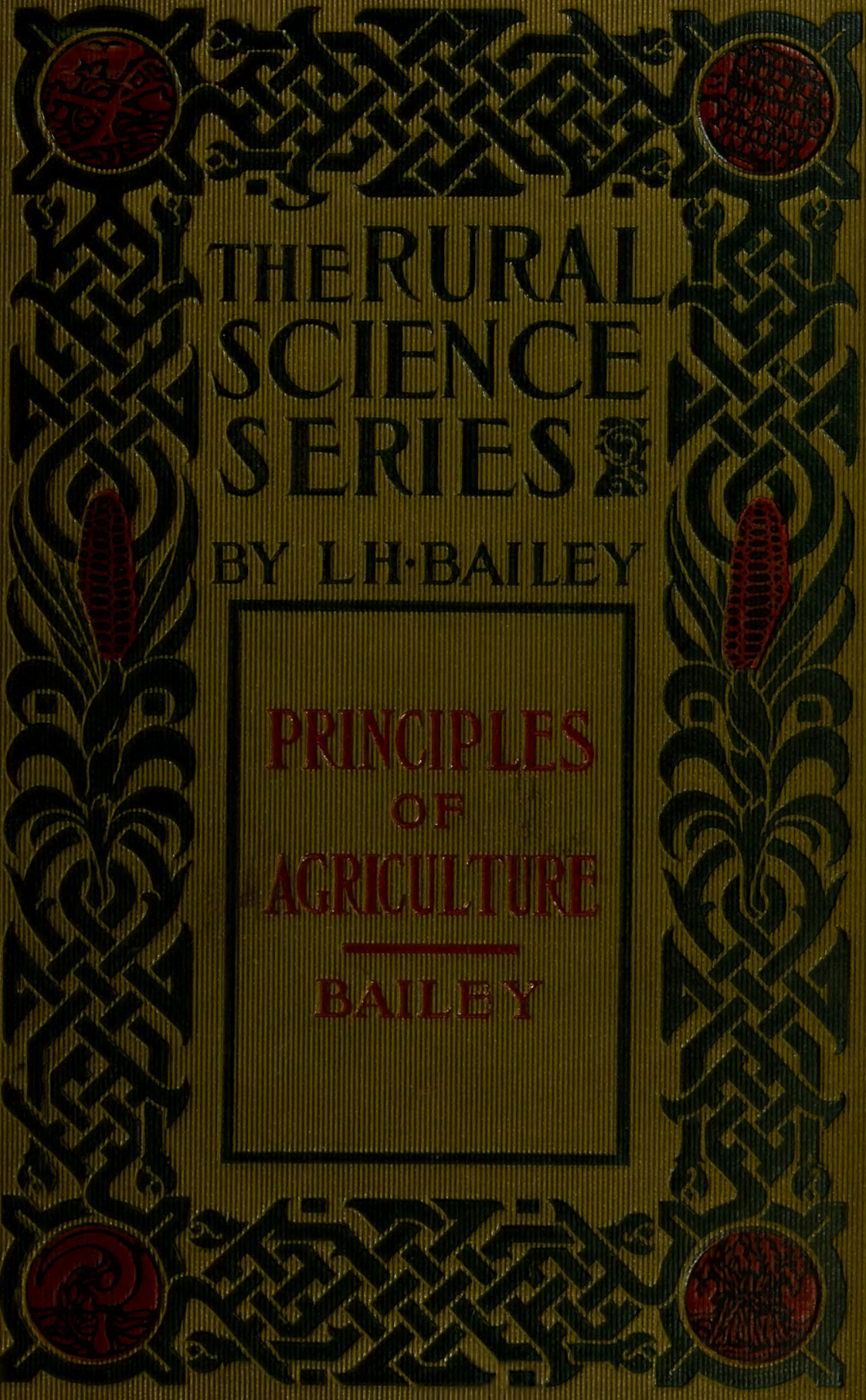



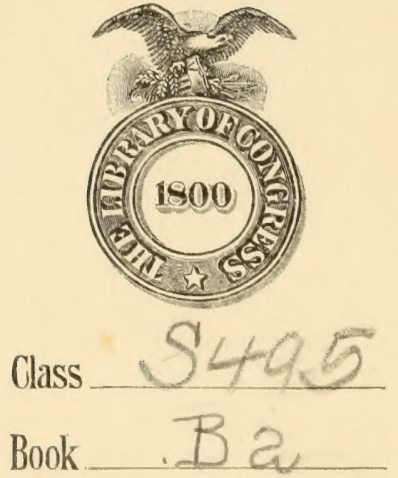

Copyright N. 1909 COPYRIGHT DEPOSIT: 


The lautal Stience Serieg

EDITED BY L. H. BAILEY

\section{THE PRINCIPLES OF AGRICULTURE}




\section{The thural Science Series}

THE SOIL.

The Spraying of Plants.

Milk AND Its Products.

'The Fertitity of the Land.

The Principles of Fritit Growing.

Bush-Fruits.

Fertilizers.

The Principles of Agriculture.

RURAl Wealth aNd Welfare.

The Farmstead.

The Principles of Vegetable-Gardening.

Farm Poultry.

The Feeding of Animals.

The Farmer's Business Handbook.

IRrigation and DRAINAge.

The Care of Animals.

The Horse.

How to Choose a FARM.

Forage Crops.

Bacteria in Reiation to Country Life.

The Nursery-BoOK.

Plant-Breeding.

The Forcisg-Book.

GARDEN-MAKING.

The Pruning-Book.

The Practical Garden-Book. 


\title{
THE PRINCIPLES OF AGRICULTURE
}

\author{
A Text-Book For \\ Schools and Rural Societies
}

\author{
EDITED BY \\ L. H. BAILEY
}

Fifteenth Edilion, Revised

With a review and catechism for readingclubs and teachers

\author{
Aivin 热ark \\ THE MACMILLAN COMPANY \\ LONDON : MACMILLAN \& CO., LTD. \\ 1909 \\ All rights reserved
}




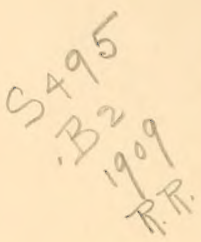

Copyright, 1898, 1909

By L. H. BAILEY

Set up and electrotyped December, 1898

Reprinted with corrections January, 1900; January, May, 1901

February, June, 1902; February, July; 1903; March, 1904 July, 1905; April, 1906; August, 1907; June, 1908

January, 1909; Revised, June, 1909

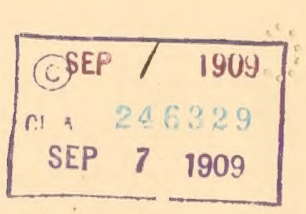

90unt Doleasant 10reg口

J. Horace McFarland Company

HARRISBURg - PENNSYLVANIA 


\section{PREFACE}

The greatest difficulty in the teaching of agricul.* ture is to tell what agriculture is. To the scientist. agrieulture has been largely an application of the teachings of agricultural chemistry; to the stockman, it is chiefly the raising of animals ; to the horticulturist, it may be fruit-growing, flower-growing, or nursery business; and everyone, since the establishment of the agricultural colleges and experiment stations, is certain that it is a science. The fact is, however, that agriculture is pursued primarily for the gaining of a livelihood, not for the extension of knowledge: it is, therefore, a business, not a science. But at every point, a knowledge of science aids the business. It is on the science side that the experimenter is able to help the farmer. On the business side the farmer must rely upon himself; for the person who is not a good business man cannot be a good farmer, however much he may know of science. These statements are no disparagement of science, for, in these days, facts of science and scientific habits of thought are essential to the best farming: hut they are intended to emphasize the 
fact that business method is the master, and that teachings of science are the helpmates.

But even if these facts are fully apprehended, the teacher and the farmer are apt to make no distinction between the fundamental and the ineidental applications of science, or between principles and facts. Therefore, the mistake is often made of teaching how to overcome mere obstacles before explaining why the obstacles are obstacles. How to kill weeds is a mere incident; the great fact is that good farmers are not troubled with weeds. Rather than to know kinds of weeds, the farmer should know how to manage his land. How to know the weeds and how to kill them is what he calls practical knowledge, but, standing alone, it is really the most unpractical kind of knowledge, for it does not tell him how to prevent their recurrence year after year. The learner is apt to begin at the wrong end of his problem. This is well illustrated in the customary discussions of under-drainage. The pupil or the reader is first instructed in methods of laying drains. But drainage is not the unit. The real unit is texture and moisture of soils: plowing, draining, green-cropping are means of producing a given or desired result. The real subject-matter for first consideration, therefore, is amelioration of soil rather than laying of drains. When the farmer has 
learned how to prepare the land, and how to grow plants, and how to raise animals, then he may enquire about such incidental details as the kinds of weeds and insects, the brands of fertilizers, the varieties of apples, when he shall till, whether he shall raise wheat or sweet errn. The tailor first learus how to lay out his garment; but the farmer too often wants to sew on the louttons before he cuts his eloth.

Again, the purpose of education is often misunderstood by both teachers and farmers. Its purpose is to improve the farmer, not the farm. If the person is aroused, the farm is likely to be awakened. The happy farmer is a more successful farmer than the rich one. If the educated farmer raises no more wheat or cotton than the nneducated neighbor, his education is nevertheless worth the cost, for his mind is open to a thousand influeuces of which the other knows nothing. One's happiness depends less on bushels of coru than on entertaining thoughts.

Not only do we need to know what agrieulture is, but we should know the relative importance of its parts. It is commonly assumed that fertilizing the land is the one most fundamental thing in agriculture, but this is not so; for if but one thing about farming practicess were to he explained, that thing should be the tilling of the land. 
viii

Agrieulture, then, stamds upon business, but seience is the staff. Businesis eatumot be taught in a book like this; but some of the litws of seience as applied to farm-mamagement ram be taught, and it is convenient to speak of these laws as the principles of arrobulture. These primeiples are arramged in a more or less loginal oreler, so that the teateher may have the skeleton of the subjeret hefores him. The subjeret shombl not be tameht mutil it is andyzed, for analysis smpplies the threal upon which the farets and pratetiens mily be strung. The best part of the book, therefores, is the table of contents.

A book like this shomld la used omly ly persons who know how to olserve. The stanting-point in the feaching of acrionlture is nature-study, - the traninge of the powere atetuilly to sere thingse and then to draw inopere romelusions from them. Into this mimary field the anthor hopes to anter ; but the present nered serems to be for a book of princoiples designed to aid those who know how to nse their eyes.

L. H. BAILEY.

HORTICUTURA, DIPARTMINT,

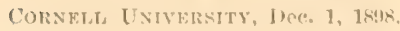




\section{ANALYSIS}

\section{INTRODUCTION (pages $1-15$ )}

1. That

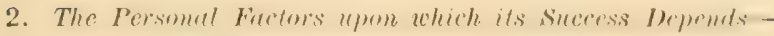

2a. Upon business or executive ability . . . . . 10-12

2b. Upon a knowledge of natural science . . . . . 13-21

3. Its Field of Production. . . . . . . . . . . . 22

\section{PART I \\ TH H SOIL}

CHAPTER I

The Contents of the Soll (pages 16-36)

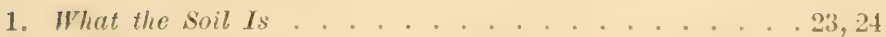

2. How soil is Mate-

"2u. The inorganic element.s. . . . . . . . . . 25-28

2y. The organic elements and agents . . . . . . 29-35

2e. 'Transportation of soils . . . . . . . . 36-40

3. The Resources of the suil . . . . . . . . 41-48

\section{CHAPTER II}

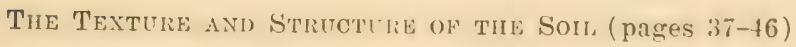

1. What is Meant by Texture . . . . . . . . 49-51

2. Why Good Texture and strueture are Important. . . . 52,53

3. How Good Structure Is Obtained . . . . . . . . 54-59

4. Structure and ILanures............ 60 


\section{CHAPTER III}

The Moisture in The Soll (pages 47-63)

(By L. A. Curnton, Director, Storrs Experiment Station, Conn.)

Paragraphs

1. Why Moisture Is Important . . . . . . . . . . . 61-63

2. How Hater is Held in the Soil . . . . . . . . . . . . 64-69

3. How the Moisture-holeling Capacity of the Soil May be

Increased -

$3 a$. The capacity of the soil . . . . . . . 70-72

3h. Capacity is increased by the addition of humus. 73, 74

3c. Capacity may be increased by under-drainage . 75-78

$3 d$. The eapacity is increased by proper tillage . . 79-81

4. The Conservation of Moisture . . . . . . . . . . . 82,83

CHAPTER IV

The Tillage of The SoIL (pages 64-76)

1. What Tillage Is. . . . . . . . . . . . . . 84-86

?. That Tillage Does . . . . . . . . . . . . . . . . . 87-89

3. How Tillage Is Performed-

3a. By deetp-working tools . . . . . . . . . . . . 90-97

36. By surface-wolking tools . . . . . . . . . 98-101

3c. By compacting tools . . . . . . . . . 102-104

\section{CHAPTER V}

Evriching THE SoIL-FArM Resources (pages 77-86)

1. What Farm Resources Are. . . . . . . . . . . . . 105-107

2. Cropping Resources -

$2 a$. The kinds of green-manures . . . . . . 108-111

2b. The management of green-manures . . . . 112-117

3. Direct Applications-

3a. Stable manures . . . . . . . . . . 118-122

3b. Other dressings. . . . . . . . . . . 123-1:6 


\section{CHAPTER VI \\ ENRICHiNg the SoIL - Commercial Resources \\ (pages 87-105)}

(By G. W. Cavanaugh, Professor of Agricultural Chemisty, Cornell University)

Paragraphs

1. The Elements in the Soil. . . . . . . . . . . 127-133

2. Nitrogen . . . . . . . . . . 134-139

3. Phosphoric Acid. . . . . . . . . . . 140-145

4. Potash . . . . . . . . . . . . . . . . . . . . . . .

5. Amendments. . . . . . . . . . . 149-153

6. Commercial Fertilizers-

$6 a$. What they are. . . . . . . 154-15i

6b. Adrice as to their use ........... 158-166

PART II

\section{THE PLAN'T, AND CROPS}

\section{CHAPTER VII}

The Offices of the Plant (pages 106-111)

1. The Plant and the Crop . . . . . . . . . 167, 168

2. The Plant in its Relation to Suril . . . . . . . . . 169171

3. The Plant in its Relation to Climate . . . . . . 172,173

4. The Plant in its Relation to Animal Life...... 174,175

5. The Plant has Intrinsic Falue to Man-

$5 a$. As articles of food or beverage . . . . . 176,177

5b. As articles used in the arts. ....... 178

5c. As articles or objects to gratify æesthetic tastes . 179-181

\section{CHAPTER VIII}

How the Plant Lives (pages 112-131)

(By B. MI. DugGar, Professor a f Plant Physiology, Cornell University)

1. The Plunt Actirities. . . . . . . . . 18: 18:3 
2. The Factors of Growth-

Paragraphs

2a. Water in the plant

$184-189$

2b. Soluble salts from the soil . . . . . . . 190-192

2c. Oxygen . . . . . . . . . . . . 193-196

2d. Carbon dioxid and sunlight. . . . . . . . 197-199

2e. Heat, or a definite temperature . . . . . 200-202

3. The Processes of Growth. . . . . . . . . . . . . 203-207

4. Irritability

$\because 08-21 \div$

\section{CHAP'TER IX}

The Propagation of Plants (pages 132-144)

1. The Finds of Propagation . . . . . . . . . . . . . 213-215

$\because$ Seedarye, or Propagation by Seeds-

2 $a$. Requisites of germination . . . . . . . 216-221

2b. The raising of seedlings . . . . . . . . 222-226

3. Propagation by Buds-

$3 a$. Why and how bud propagation is used . . . 227, 228

36. Lindetalcheel buds. . . . . . . . . . . . 229, 230

3c. Detached buds.............. . . 231-241

\section{CHAPTER I}

Preparation of LAND FOR THE SEed (pages 145-158)

(By I. P. RoBerts, Emeritus Professor of Agriculture,

$$
\text { Cornell University) }
$$

1. Hactors IIhich Determine the Preparation of the Sect-bed. 242, 243

2. The Jemunds of the Plant . . . . . . . . . . 244-249

3. The Preparing of the Seed-bed . . . . . . . . . . 250-255

4. Application of the Frorgoing Principles-

4a. Wheat.

46. Maize, or Indian eorn . . . . . . . . 260,261

4c. Potatores . . . . . . . . . . . . . . . . 26tit

\section{CHAPTER XI}

Subsequent Care of the Pluant (pages 159-178)

1. By Means of Tillage-

1a. In genergl . . . . . . . . . 265-270

1b. In fruit plantations 
2. By Means of Pruning and Training-

Paragraphs

2a. Pruning vs. training . . . . . . 278, 279

$2 b$. The healing of wounds . . . . . . . 280-284

2c. The prineiples of pruning . . . . . . . 285-289

3. By Keeping Enemies in Check-

3a. The kinds of enemies . . . . . . . . . 290-293

3b. The preventives and remedies . . . . 294-303

CHAP'TER XII

Pastures, Meadows, and Forage (pages 179-200)

(By I. P. ROBERTS)

1. Grass. 304-306

2. Permanent Pastures -

2a. Preparation of the land . . . . . . . . 307-310

2b. Maintaining the pasture . . . . . . 311-317

3. Meadows-

$3 \alpha$. Temporary meadows . . . . . . . 318-321

3b. Permanent meadows . . . . . . . . . 322-325

3\%. Kinds of grasses for meadows . . . . . . . .326-329

4. Other Forage Plants. . . . . . . . . . 330-335

\section{PAR'T III}

\section{THE ANIMAL, AND STOCK}

\section{CHAPTER XIII}

The Offices of the Animal (pages 201-207)

1. The Animal and the Stock . . . . . . . . . . . 336,337

2. The Animal in 1ts Relation to the soil . . . . . . . 338, 339

8. The Animal in Its Relation to the Crop . . . . . . . 340,341

4. The Animal has Intrinsic Value to Man-

4a. As articles of food . . . . . . . . . . 342-344

4b. As articles used in the arts . . . . . . 345, 346

4c. As companions . . . . . . . . . 347

5. The Animal as a Beast of Burden . . . . . . 348-350

6. The Animal as a Pest-destroyer ....... . . . 351,352

7. The Animal Diversifies Labor. . . . . . . . . 353,354 


\section{CHAPTER XIV}

\section{How the ANimal Lives (pages 208-238)}

(By James LAw, Ex-Director of the New York State Veterinary College, Coruell University)

1. The Cell, and its Part in the Vital Processes-

Paragraphs

1 $\alpha$. The cell .............. 355

1b. Single-celled animals . . . . . . . . 356-359

1c. Many-celled animals . . . . . . . 360-366

2. The Food of Animals-

$2 a$. Kind of food . . . . . . . . . . 367,368

2b. Food constituents . . . . . . . 369-376

3. Digestion of Food-

$3 a$. What digestion is . . . . . . . 377,378

36. The saliva . . . . . . . . . . . . . 379-385

3c. The gastrice juice . . . . . . . . . . 386-393

3d. Intestinal digestion . . . . . . . . 394-401

4. Absorption of the Digested Matters-

4a. How absorption takes place . . . . . . 402-404

$4 b$. Destination of the rich blool from the intestines. 405-409

5. Respiration, or Breathing-

5 (九. What breathing is . . . . . . . . . . 410-413

5 b. Blood-changes in respiration . . . . . . 414-418

$5 c$. Amount of air required . . . . . . . 419-421

6. Work; ITaste; Rest-

6a. Waste of tissue . . . . . . . . . 422,423

6b. Applications to practice . . . . . . 424-426

\section{CHAPTER XV}

The Feeding of the Animal (pages 239-257)

(By H. H. WING, Professor of Animal Husbandry in

Cornell University)

1. Someress of Fond of Animals . . . . . . . . 427, 428

2How the Animal Uses Food ........... 429-435 
3. Composition of Fodders -

3九. Classification ............ 436

3b. Water . . . . . . . . . . . 437-439

3с. Ash . . . . . . . . . . . . 440,441

3d. Albuminoids . . . . . . . . . 442444

3e. Carbohyhrates . . . . . . . . . . 445-447

$3 f$. Fats . . . . . . . . . . . . 448,449

4. Feeding-

4a. Nutritive ratio . . . . . . . . . 450-457

4b. Quantity of food required ....... 458-463

4c. Feeding standards ........ . . . 464, 465

4d. Bulk in the ration. . . . . . . . 466-468

4e. Palatableness .......... . . . . 469, 470

4f. Cooking and preparing the food . . . . . 471-473

\section{CHAP'TER XVI}

The Management of Stock (page 258-278)

(By I. P. ROBERTS)

1. The Breeding of Stock-

1a. What is meant by breeding . . . . . . 474-477

1b. The mental ideal. . . . . . . . . 478-481

1c. How to attain the ideal ...... . . . . 482487

2. Where Stock-raising Is Advisable. . . . . . . . .488-491

3. How Much Stock May be Kept. . . . . . . . . . . 492-500

4. The Care of Stock-

$4 a$. Housing . . . . . . . . . . . . . 501-505

4b. Water . . . . . . . . . . 506,507

4c. Food . . . . . . . . . 508 510

GLOSSARY (pages 281-288)

SUGGESTIONS TO READING CLUBS AND TO TEACHERS (pages 289-323)

INDEX (pages 325-336) 



\section{THE PRINCIPLES OF AGRICULTURE}

\section{IN'TRODUCTION}

\section{What Agriculture Is}

1. Agriculture, or farming, is the business of raising products from the land. These products are of two classes: crops, or plants and their products; stock, or animals and their products. The former are direct products of the land; the latter are indirect products of the land.

2. Agrienlture also comprises, to a certain extent, the marketing or selling of its products. As marketable commodities, the products are of two classes: primary, or those which are put on the market in their native or natural condition, as wheat, potatoes, bananas, eggs, milk, wool; secondary, or those which are put on the market in a manufactured condition, as butter, cheese, cider, evaporated fruits.

3. The chief contribution of agriculture to the wealth and welfare of the world is the production of food. Its second contribution is the production of materials for clothing. Its thiml

A 
is the production of wood or timber, used in building and in the various wood-working trades. Other contributions are the production of materials used in medicine and in various secondary and incidental arts and manufactures. 4. The ideal agrieulture maintains itself. That is, it is able to thrive forever on the same land and from its own resources. The land becomes more productive with time, and this even without the aid of fertilizing materials from the outside. 'This state is possible only with a mixed husbandry, in which rotations of erops and the raising of animals are necessary features. The more specialized any agrieultural industry becomes, the more must it depend upon ontside and artificial aids for the emrichment of the land and for its continued support.

5. Agrienlture may be roughly divided into four general branches of departments: agrieulture in its restricted sense, animal industry, forestry, horticulture.

(j. Agrieulture in its restrieted sense-sometimes, but erroneously, called agrieulture properis a term applied to the general management of lands and farms, and to the growing of the staple grain and filner "rops. In North America, the use of the term agrienlture has been restricted to the above application largely through the influence of agricultural colleges and experiment 
stations, in which the general field of agriculture has been divided into various special subjects.

7. Animal industry is the raising of animals, either for direct sale or use or for their produets. It is enstomary to speak of it as comprising three repartments: stock-raising, or the general growing of mammals, as cattle, horses, sheep; dairy husbandry, or the production of milk and milk products; poultry-raising, or the growing of fowls, as chickens, turkeys, geese, ducks. In its largest sense, it comprises other departments, as apiculture or bee-raising, fisl-culture, ostreaculture or oyster-raising, and the like.

8. Forestry is the growing of timber and woods. Its oljects are two: to oltain a salahe product; to produce some secondiny effect upon the region, as the modification of climate or the preservation of the water-supply to rivers and lakes.

9. Horticulture is the growing of fruits, kitehen-garden regetables, and ornamental plants. It has been divided into four departments: pomology, or fruit-growing; olericulture, or vegetable-gardening; floriculture, or the growing of flowers and plants for their own (1) individual uses as means of ormament; landseape horticulture, or the growing and planting of ornamental plants for their uses in mass effects in the landscape (on the lawn). 


\section{The Personal F'actors Upon Which Its Success Depends}

\section{2a. Upon business or executive ability}

10. Since the farmer makes a living by means of trade, it follows that ability to manage business and affairs is requisite to his surcexs. Fxecutive ability is as needful to him as to the merchant or the manufareturel; and the lack of such ability is probably the commonest and most serious fiult with our agrieulture. As the conditions of trade are ever changing, so the methods of the farmer must be amenable to modification. He must quickly and completely adapt himself to the commeree of the time. Manifestly, howerer, this business calpability amnot be tamght by books. It is a matter of temperament, home training, and opportunity. Like all permanent suress, business prosperity depends npon correct thinking, and then upon the correct application of the thinking. Sueressful agriculture, therefore, is a matter of personality more than of cireumstances.

11. The compound result of executive ability and experience may he expressed in the term farm-practice. It is the judgment of the farmer upon the question in hand. However much he may learn from science, his own 
experience on his own farm must tell him what crops to grow, how to fertilize his land, what breeds and varieties to raise, when and how to sow and to reap. The experience of one farmer. is invaluable to another, but each farm is nevertheless a separate and local problem, which the farmer must think out and work ont for himself.

12. The farmer must be able not only to raise his products, but also to sell them. He. must produce either what the trarle demands, or be able to sell products which are not known in the general market. In other work, there are two types of commercial effort in farming: growing the staple products for the world's markets (as wheat, heans, maize, meat), in which case the market dictates the priec; growing special products for particular or personal sale (as the products of superior excellence, and inxuries), in which ease the protueer looks for his enstomers and dictates the price.

\section{2b. Upon a knowledge of natural science}

13. The farmer, however, has more problems to deal with than those romnected with trade. He must raise products: and snch production depends upon the exereise of much special knowlerlge and skill. The most suecessful pro- 
ruction of agrienltural products rests npon the application of many principles and facts of natural science; and the importance of such application is rapidly increasing, with the contpetitions and complexities of rivilization. The sturly of these natural seionees also establishes habits of endrect thinking, and opens the mind to a larger enjoyment of life,-for happiness, like sucersse, depends mon habits of thonght. The farmer should live for himself, as well as for his copos. The seiences mon the knowlerdge? of which the hest agrientural practice chiefly depends may now be mentioned, being stated approximately in the oreler of their importanes. to the actual praretion of the modern farmer.

14. Physies. The physionl poperties amel arotions of bodies are fumblamentally ronerenesl in erery angireultural result, whether the farmer knows it or not. 'The influenees of light and heat, the movements of fluids in soil, plant amr animal, the forees roncerned in every machine and appliance, are some of the most obvious of these physical problems. So important to the farmer is a knowledge of physies that "agrieultural physies" is now a subject of instruction in colleges. The most important direset application of a knowledge of physies to agricultural practice has rome as a lesult of recent studies of the soil. The equestions of soil moisture, soil 
texture, the tilling of land, and the acceleration of chemical activities in the soil, are essentially questions of physies; and these are the kinds of scientific problems which the farmer needs first to apprehend.

15. Mechamies. In practice, mechanies is an application of the laws of physies. The elementary principles of mechanics are apprehended ly the farmer uneonseiously, as a result of rxperience; but since modern agriculture is impossible without numerous and often elaborate mechanical derices, it follows that it is not enough that the finmer be self-tanght. At every turn the farmer uses or applies physical forces, in tools, rehicles, and machines. His work often takes him into the field of civil engrineering. To show how much the farmer is dependent on practioal mechanics, we need mention only implements of tillage, problems assoriated with the draughts of horse took, the elaborate harvesting machinery, threshers and feed-mills and milk-working machinery and the power to rum then, fruit evaporating machinery, pmmss, windmills, hylraulic rams, constrution of water supplies, problems of animal locomotion.

16. Plant-knowledge, or botany. Since the plant is the primary product of the farm, a knowiedge of its characteristies and kinds is of 
fundamental importance to the farmer. From the farmer's stamlpoint, there are four great departments of plant-knowledge: physiology, or a knowledge of the way in which the plant lives, grows, and multiplies; pathology, or a kuowledge of mal-nutrition and diseases; systematie botany, or a knowledge of the kinds of plants; ecology, or a knowledge of the inter-relations between plants and their enviromments (or surromdings), and how they are modified by rhanges in environments, by crossing, and by breeding.

17. Animal-knowledge, or zoölogy. There are also four general directions in which animalknowlerlge appeals to the farmer: physiology, with its practical applications of feeding, housing, and ceneral cares of animals; pathology, or knowledge of mal-nutrition and diseases (with special applieations in the practices of surgery and medienese); kinds of animals, and the lifehistories of those which are particularly beneficial or injurious to agrirulture (with special applieations in eronomic entomology and eronomie ornithology); ecology and breeding.

18. ('hemistry. There are two general direetions in which rhemistry appeals to the agrlcolturist: in enlarging his knowledge of the life-processes of plants and animals; and in affording direct information of the composition 
of many materials used $o l^{\circ}$ produced on the farm. In practice, chemistry aids the farmer rhiefly in suggesting how he may feerl plants (fertilize the land) and animals. So many and important are the aids which chemistry extends to agriculture, that the various subjects involved have been associated under the name of "agri"ultural chemistry." This differs from other chemistry not in kind, but only in the subjects which it considers.

19. Climatology. Climate determines to a large extent the particular treatment or care which the farmer gives his rops and stock. It also profoundly influences plants and animals. 'They change when climate changes, or' when they are taken to nther climates. Climate is therefore a powerful agency in producing new breeds and new varieties. The science of weather, or meteorology, is also intimately associated with the work of the farmer.

20. Geology. The agricultural possibilities of any region are intimately associated with its surface geology, or the way in which the soil was formed. A knowledge of the geology of his region may not greatly aid the farmer in the prosecution of his business, but it should add much interest and zest to his life.

21. We now apprehend that agriculture is a complicated and difficult business. Founded 
upon trade, and profoundly influenced by every commercial and economic condition, its successful prosecution nevertheless depends upon an intimate and even "xpert knowledge of many natural sciences. Aside from all this, the farmer has to deal with great numbers of objects or facts: thousands of species of plants are cultivated, and many of these species have hmondreds and thousands of varieties; many species of animals are domesticated, and each speries has distinct lneeds. Each of these separate facts demands specific treatment. Moreover, the conditions under which the farmer works are ever changing: his immmerable prollems are endlessly varied and complicated by rlimate, seasons, vagaries of weather, attacks of pests and diseases, fluctuations in lahor supply, and many other umpredictahle factors.

\section{Its Field of Production}

22. In the production of its wealth, agriculture operates in three great fields, -with the soil, the plant, and the animal. Although aided at every point by knowledge of other subjects, its final success rests upon these bases; and these are the fields, therefore, to which a textbook nlay give most profitable attention. 
1a. The word agriculture is a compound of the Latin agri, "field," and cultura, "tilling." Farming and husbandry are synonymous with it, when userl in their broadest sense; but there is a tendeney to restrict these two words to the immediate practice, or practical side, of agriculture.

$2 \imath$. It is often difficult to draw a line of demarkation between agriculture and manufacture. The husbandmen is often both farmer and manufacturer. Nanufacturing which is done on the firm, and is of secondary importance to the raising of crops or stock, is commonly spoken of as agriculture. The manipulation or manufacturing of some agricultural products requires such special skill and appliances that it beeomes a business by itself, and is then manufacture proper. Thus, the making of flour is no longer thought of as agriculture; and the making of wine, jellies, cheese, hutter, canned fruits, and the like, is coming more and more into the category of special manufacturing industries. Strictly speaking, agriculture stops at the factory door.

3u. Agriculture is often said to be the most fundamental and nseful of orempations, since it feeds the world. Theoretically, this may be true: hut a high state of civilization is possible only with diversification of interests. As civilization advances, therefore, other oceupations rise in relative importance, the one rlepending upon the other. In our modern life, agriculture is impossihle without the highly developed manufacturing and transportational trades. Broadly speaking, eivilization may he said to rest upon agrieulture, transportation, and manufacture.

4a. Nixed husbandry is a term used to denote the growing of a gentral viriety of farm erops and stock, especially the growing of gratss, grain, with grazing (pasturing) and general stock-raising. It is used in distinction to specialty-farming or the raising of particular or special things, as fruit, bees, regetables, beef, eggs.

4h. Self-perpetuating industries conduce to stability of politieal and social institutions. "The epochs which precede the agrieultural occupation of a country are commonly about as 
follows: Discovery, exploration, hunting, speculation, lumbering or mining. The real and permanent prosperity of a country begins when the agriculture has evolved so far as to he self-sustaining and to leave the soil in constantly better condition for the growing of plants. Lumbering and mining are simply means of utilizing a reserve which nature has laid hy, and these industries are, therefore, self limited, and are constantly moving on into unrobbed territory. Agriculture, when at its best, remains forever in the same place, and gains in riches with the years; but in this country it has so far been mostly a species of mining for plant-food, and then a rushing on for virgin lands."-Principles of Fruit-Growing, 26.

$8 a$. Forestry is popularly misunderstood in this country. The forest is to he considered as a crop. The salable product begins to be obtainable in a few years, in the shape of trimmings and thinnings, which are useful in manufacture and for fuel; whereas, the common notion is that the forest gives no return until the trees are old enough to cut for timber. One reason for this erroneous impression is the fact that wood has been so abumdant and cheap in North Ameriea that the smaller products have not heen considered to be worth the saving; but even now, in the manufacture of various articles of commerce, the trimmings and thinnings of forests should pay an income on the investment in some parts of the country. If a manipulated forest is a crop, then forestry is a kind of agriculture, and it should not be confounded with the mere hotany of forest trees, as is commonly done.

$9 a$. The word horticulture is made up of the Latin horks, "garden," and cultura, "tilling." In its broadest sense, the word garden is its equivalent, but it is commonly used to designate horticulture as applied to small areas, more particularly when the subjects are flowers and kitchen-garden vegetables. Etymologically, garden refers to the engirded or confined (walled-in or fenced-in) area immediately surrounding the residence, in distinction to the ager (1a) or field which lay beyond. Hortus has a similar significance. Paradise is, in etymology, a name for an enclosed area; and the term was 
given to some of the early books on gardening, e.g., Parkinson's "Paradisus Terrestris" (1629), which is an account of the ornamental plants of that period.

14a. King's book on "The Soil" explains the intimate relation of physical forces to the productivity of the land; and the author is Professor of Agricultural Physics in the University of Wisconsin. There is a Bureau of Soils in the National Department of Agriculture, the work of which is largely in the field of suil physics. The physical or mechanical analysis of soils is now considered to be as important as the chemical analysis. Some of the physical aspects of farm soils are diseussed in our chapters ii., iii., iv., v.

16 $\iota$. Ecology (written acology in the dictionaries) is the science which treats of the relationship of organisms (that is, plants and animals) to each other and to their environments. It is animal and vegetable economy, or the general external phenomena of the living world. It has to do with modes and habits of life, as of struggle for existence, migrations and nesting of birds, distribution of animals and plants, influence of clmmate on orgunisms, the way in which any plant or animal behaves, and the like. Darwin's works are rich in ecological observations.

16b. Environnent is the sum of conditions or surroundings or circumstances in which any orgunism lives. An environment of any plant is the compound condition produced by soil, climate, altitude, struggle for existence, and so on.

18a. It is customary to consider agricultural chemistry as the fundamentul science of agriculture. Works on agricultural chemistry are often called works on agrieulture. But agriculture has no single fumlamental science. Its success, as we have seen, depends upon a union of business methods and the applieations of seience: and this science, in its turn, is a coördination of many sciences. Chemistry is only one of the seivenees which contribute to a better agriculture. Under the iuspiration of Dary, Liebig, and their follower's, agricultural chemistry madu the first great application of science to agriculture; and upon this foundation has grown the experiment-station illea. It is 
not stranger, therefore, that this seienee should be more intimately assoselated than of hers with agrionltural ieleas ; but we

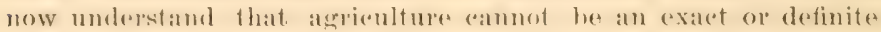
science, and that the retort and the crucible can solve only a fow of its many problems. In particular, wo must outgrow the idea that by analyzing soil and plant wo can determine what the one will produce and what the other needs. Agrieultural chemistry is the product of Iaboratory methods. 'The resits of these methods may not apply in the field, becuuse tho conditions there are so diflerent and so variable. The soil is the laboratory in which the chemical activitios take place, but conditions of weather aro over modifying these activities; and it is not always that the soil and the plant are in condition to work together.

20a. As an illustration of the agricultural interest which attaches to the surface geology of a region, seo 'Tarr's "Geological History of the Chautauqua Grape Belt," Bull. 109 Cornell Exp. Sta.

21a. Probably no less than 50,000 species of plants (or forms which have been considered to bo species) have been cultivated. 'T'he greater number of these are ornamental subjects. Of orchids alone, as many as 1,500 species have been

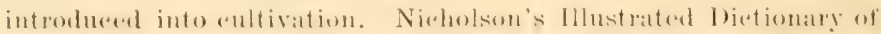
Aarlening deseribes about 40,000 spereics of domestieated plants.

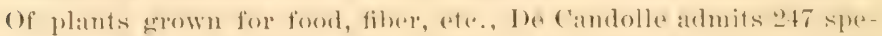
ries (in Orinin of ('ultivated Jlants), lut theses are only the most

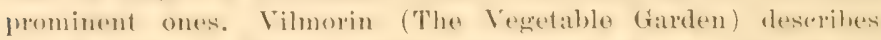

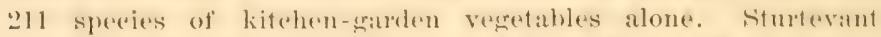

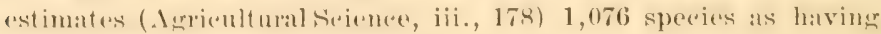
been "recorded as eultivated for food use." Of some species, tho eultivated varieties are numbered by the thousands, as in apple, ehrysanthemum, earnation, potato. Of animals, more than 50 species aro domestiented, and the breeds or varieties of many of them (as in eattlo) run into the hundreds.

216. It is commonly said that agriculture is itself a seieuce, but we now see that this is not true. It has no field of seience exclusively its own. Its purpose is the making of a living for its practitioner, not the extension of knowledge. The subject of 
mathematies is numbers, quantity and mannitude; of loofany. plants; of ornitholougy, hirls; of "ntomology, insecots; of chomistry, the composition of matter; of astronomy, tho heavens: but agriculture is a mosaic of many seiences, arts and activities. Or, it may be said to be a composite of sciences and arts, much as modicine and surgery are. But if there is no seience of arriculture as distinct from other scionces, the prosecution of agrienlture must be seientifie; and the fact that it is a mosale makes it all the more difficult to follow, and enforees the $\mathrm{im}$. portance of executive judgment and farm-practice over merte scientific knowledge.

22, 'The province of a text-book of agriculture, in other'

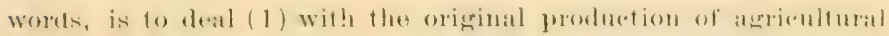
wealth rather than with its manufacture, transportition or sale,

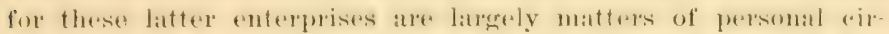
comstance and individuality, and (2) with those principules and facts which aro common to all agriculture, or which ma be considered to be fundamental.

22b. In other words, we must search for principles, not for mere facts or information: wo shall seok to ask why before we

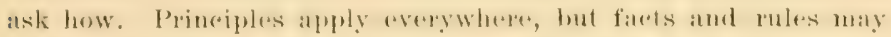
apply only where they originate. Agrioulture is fommled upon laws; but there are teachors who would have us believe that it is ehiefly the overcoming of more obstacles, as insects, unpropitions weather, and the like. Theres are great fumdamentals which the learner must compreheme therefore we shall say nothing, in this book, about the incidentals, as the kinds of wereds, the brands of tertilizers, the breeds of animals, the varieties of flowers. 


\section{PART I THE SOIL}

Chapter I

\section{THE CONTENTS OF THE SOIL}

\section{What the Soil Is}

23. The earth, the atmosphere, and the sumlight are the sources of all life and wealth. Atmosphere and smlight are practically beyond the control of man, but the surface of the land is amenable to treatment and amelioration.

24. The soil is that part of the solid surface of the earth in which plants grow. It varies in depth from less than an inch to several feet. The uppermost part of it is usually darkest colored and most fertile, and is the part which is generally understood as "the soil" in common speech, whereas the muder part is called the sub-soil. When speaking of areas, we use the worl land; but when speaking of the particular agricultural attributes of this land, we may use the word soil. 


\section{How Soil Is Made}

\section{2a. The inorganic elements}

25. The basis of soil is fragments of rock. To this base is added the remains of plants and animals (or organic matter). When in comlition to grow plants, it also contains water. The character of any soil, therefore, is primarily determined by the kind of rock from which it has come, and the amount of organic matter and water which it contains.

26. As the surface of the earth cooled, it berame rock-homul. Wrinkles and ridges alppeared, forming mountains and valleys. 'The tendency is for the alevations to be lessened and the depressions to be fillerl. That is, the surface of the earth is heing leveled. The chief ageney in this leveling process is weathering. The hills and mountains are worn down by alternations of temperature, by frost, jee, snow, rain and wind. They are worn away hy the loss of small particles: theses particles, when anthered on the hillsides or depesited on lower levels, form soil.

27. The weathering ageneres which reduce the mountains operate also on level areas; but since the soil then remains where it is formed, and thereby affords a protection to the underlying rock, the reduction of the rock 
msually procesers more slowly than on inclined surfaces.

28. 'There are, then, two sets of foleres concomerl in the original formation of soils, - the disintegration of wearing away of the rock, and the transfer or moving of the particles to other places.

\section{2b. The organic elements and agents}

2). Plants alle important agents in the formation of soil. Their action is of two kincls: the roots colponle and break up the surficess of rock and particeles of soil, and the plant fimally decays and adeles some of its tissue to the soil.

30. In the disintergation of rock and the fining of soil, the root ants in two ways: it a ${ }^{2}-$

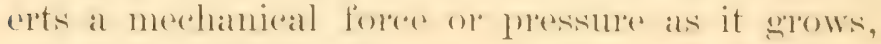

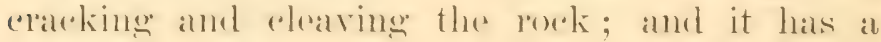
ehemical action in dissolving out certain materials, and therehy romsmming and weakening the lock.

31. Animals ontribute to the formation of soil hy their excrement and the decay of their calcatsses. Burrowing and digering animals also expose rookis and soils to weathering, and contribute te the transportation of the particles. Some animals alre oven more directly concerned in soil-making. Of these, the chief are the 
various kinds of atrthworms, one of which is the common amgleworm. These animals eat rateth, which, when excoeted, is mores or less mixed with oreanice mattere and the mineral particles are enenumb and modifiest. It is now comsirlerer that in the temacious soils in which these animals work, the earthworms have been vely important agents in fitting the aath for the soming of plants, and conserpuently for agriculture.

32 . While the basis of most soils is disintrgrated rock, there are some soils whireh are esserntially olganic in origin. 'Theses are formed hy the arommulation of verestable matter, often aided hy the incoryoration of animal remains. In the tropies, suroh soils alre often formed on shores and in lagooms by the axteresion of the trumk-like poots of manderoves and other trees. In the network of loots, leares amb sea-wrale alre canght, and mold is formert. Water plants (as marsh glasses and eel-glass) are sometimes so abmulant on sea malegins as to prontually form solid land. On tho exlges of lakes and ponds, the acemmulation of watrelelily rhizones and other growths oftron affords a foothold for sedgres anr other semi-aquatic plants ; and tho combined somth invarles the lake and often fills it. Portions of this Recaying and tangled mass are sometimes torn away by wind 
or rave, and become floating islands. Such islands are often several acres in extent. In high latitudes, where the summer's growth does not decaly quickly, one season's growth is sometimes added above another until a deep organic soil is formed. This is especially noticeable in the gradual increase in height of sphagnum swamps. Peat bogs are organic lands, and they fill the beds of former lakes or swamps. Of course, all these organic soils contain mineral matter, lunt it is mostly surh as comes from the decay of the plants themselves. It was originally obtained from the earth, but is used orer and over again; and areh year a little new material may be arlind by such plants as reach into the hard land below, and by that which blows into the area in dust.

33. Decaying organic matter forms mold or humms. The mineral elements may be said to give "horly" to the soil, but the humus is what gives it "life" or "heart." Humus makes soils dark-rolored and mellow. Humus not only adds plant-food to the soil, lut improves the physical rondition of the soil and makes it rongenial for plants. It augments the water-holding capacity of the soil, modities the extremes of temperature, facilitates the entrance of air, and accelerates many chemical activities. It is the chief agent in the formation of loam:- a sandy loam is a 
friable soil rich in vegetable matter, the original basis of which is sand ; a clay loam is one similarly ameliorated, the hasis of which is clay. "Worn-out" lands msually suffer more from lack of humus than from lack of actual plantfood, and this explains why the application of stable-manure is so efficacious.

34. There are three general ways in which humus is obtained in farm-practice: (1) By means of the regetable matter which is left on or in the groumd after the erol is remover (as roots, stubble, sod, garlen refuse); (2) by means of crops grown and plowed under for that particular purpose (green-manuring); (3) by means of direct applications to the land (as compost and stable-manure). The deeper and more extensive the root-system of any plant, the greater, in general, is its value as an ameliorator of soil, both because it itself exerts a more widespread influence $(30)$, and because when it derays it extends the ameliorating effects of humms to greater depths.

3.). Asirle from these varied component elements, fertile soil is inhabited by countless numbers of microscopic organisms, which are peculiar to it, and without which its varions chemical activities can not proceed. These germs contribute to the breaking down of the soil particles and to the decay of the organic materials, and 
in doing so, aid in the formation of plant-foods. The soil, therefore, is not merely an inert mass, operated upon only by physical and chemical forces, but it is a realm of intense life ; and the discovery of this fact has radically modified our conception of the soil and the means of treating it. Enriching the land is no longer the arding of mere plant-foorl: it is also making the soil congenial to the multiplication and well-being of micro-organisms.

\section{2c. Transportation of soils}

36. The soil is never at rest. The particles move upon each other, through the action of water, heat and cold, and other agencies. The particles, whether of inorganic or organic origin, are also ever changing in shape and composition. Ther wear away and crumble under the action of weather, water, organic acicls of the humus, and the roots of plants. No particle of soil is now in its original place. These changes are most rapid in tilled lands, because the soil is more exposed to weather through the tillage and the aerating effect of deep-rooted plants (as clover); and the stirring or tilling itself wears the soil particles. Even stones and pebbles wear away ( $26 a)$; and the materials which they lose usually become productive elements of the 
soil. Some lands have very porous or "rotten" stones, and these pass quickly into soil. Stones are $n o$ doubt a useful reserve force in farm lands, giving up their fertility very gradually, and thereby saving some of the wastefulness of careless husbandry. The general tendency, in nature, is for soils to become finer, more homogreneous, and hetter for the growth of plants.

37. But there are greater movements than these. Soil is often transported long distances, chiefly by means of three agents: moving water, ice and snow, wind. Transported soils are apt to be very unlike the underlying rock (or original surface), and they are often very heterogeneous or conglomerate in character. Soils which remain where they are formed (27) naturally partake of the nature of the bedrock, and are generally more homogeneous than transported soils, as, for example, the limestone soils which overlie great deposits of lime-rock.

38. Moring water always moves land. The beating of waves wears away rocks and stones and breaks up debris, and deposits the mass on or near the shore. Streams carry soils long distances. The particles may be in a state of suspension in the water, and be precipitated in the quieter parts of the stream or in bayous or lagoons, or they may be ilriven along the bed of the stream by the force of the current, and 
be deposited whererer obstructions orcur, or he discharged on the delta at the mouth. The deposition of sediment in timess of overflow adds new vigor to the submerged lands. The historic example of this is the Nile valley, but all bottom lands which are subjertorl to propodieal overfows exhihit the same result. Aluvial lands are formed from the deposition of the sediment of water.

39. In mombtainous regions, snow and iren rarry away grealt pumatities of rook and soil. The most powerful transporters of soil are glariers, or moving masses of ire. clareiers loosen the rock and then grind and transport it. In the slacial eporh, in which much of the northcro part of the northern hemisphere was covresed with gigantic ier-sherets slowly moving to the southward, mormous quantities of rock and rarth were transported, and deposited wherever the ire melterl. In eastern North America, the ire-front advaneed to the latitude of the Ohin river, and the boulder-strewn fields and varied soils to the nortluward of this latiture are the legaey which the epoch left to the farmer.

40. In all areas which are subjected to periods of drought, the wind transports soils in the form of dust, often in crreat amounts and for long distances. In some parts of the world, so much earth is carried by violent winds that 
these winds are known as "sand-storms." Most shores, partieularly if sandy, are much modified by the action of wind. But the wind has an influence upon soils eren in the most proteceted and equable regions. The atmosphere rontans dust, much of which is valuable plant-food. This dust is transported hy winds, and it finally settles or is rarried down ly show and rain. Although the amount of dust which is depositerd in any given time may be slight, it is nevertheless continuous, and has an important effect upon the soil.

\section{The Resources of the Soil}

41. The soil affords a root-hold for plants,a place in which they can grow. It also supplies the environmental conditions which roots need,protection, moisture, air, agreable temperature, and other congenial surroundings.

42. The soil is also a stope-homse of plantfood. Rolerts ealculates, from many analyses, that in average agrionltural lands the surface eight inches of soil on each arce contains over 3,000 pounds of nitrogen, nearly 4,000 pounds of phosphoric acid, and over 17,000 pounds of potash. These three elements are the ones which the farmer must chicfly cousider in maintaining or augmenting the productive power of the land; 
yet the figures "reveal the fact that even the poorer soils have an abundance of plant-food for several crops, while the richer soils in some cases have sufficient for two hundred to three hundred crops of wheat or maize." Tet these calculations are made from only the upper eight inches of soil.

43. Happily, this food is not all rirectly available or useful to plants (being locked up in insoluble rombinations), else it would have been exhausted by the first grenerations of farmers. It is gradually unlocked hy reather, miero-organisms, and the roots of plants; and the better the tillage, the more rapid is its utilization. Plants differ in the power to unlock or make use of the fertility of the soil.

44. Nature maintains this store of fertility by returning her erops to the soil. Every tree of the forest finally crumbles into earth. She uses the materials, then gives them back in a refined and improved condition for other plants to use. She repays, and with interest.

4.). Man remores the crops. He sents them to market in one form or another, and the materials are finally lost in sewage and the sea. He sells the productive power of his land ; yet it does not follow that he imporerishes his soil in proportion to the plant-food which he sells. Given the composition of any soil and 
of the crops which it is to produce, it is easy to calculate the time when the soil will have lost its power; but it must be remembered that the materials which the plant removes are consumed, and that the volume of the soil is reduced by that amount. The result is, therefore, that the deeper parts of the soil are bronght into requisition as fast as the upper parts are consumerl; and these depths will last as long as the earth lasts.

46. Of some materials, howerer, the plant uses more freely than of others, in proportion to their abundance in the soil. Therefore the soil may finally lose its productivity, although it is doubtful if it can ever be completely exhauster of plant-food.

47. Again, the profit in agriculture often lies in making the soil proluce more abundantly than it is of itself able to do. That is, even after tillage and every other care have forced the soil to respond to its full ability, it may pay the farmer to buy plant-food in hags in the same way that it may pay him to buy ground feed when fattening sheep. Whether it is advisable to buy this plant-food is a matter of business jurlgment which every farmer must determine for himself, after having considered the three fundamental factors in the problem: the cost of the plant-food (or fertilizer), the 
probable effect of this extra food upon the crop, and the commereial value of the extra crop. In general, it should be comsidered that in mixed hushamely the fertility of the land must be maintained loy means of farm-practice (that is, loy wool fammingre, and that plant-food should he homent only for the purpose of produring the extra product.

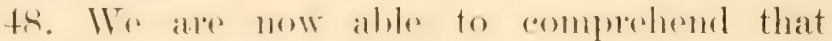
the soil is a commonud of numberless inorganie and organic materials, a realm of romplex physical and chemiral forces, and the seene of an intricato romud of life. WVe must no longer think of it as mere dirt. Moreover, we are only hoginning to molerstand it; and if the very soil is momown to us, how romplicated must be the erreat structure of arriculture which is reared upon it!

\section{SUGGESTIONS ON CHAPTER I}

Zin. Thr word organic refers to animals and plants or their products and remalus; that is, to things which live and have organs. Organic compounds, in chemistry, are those which have been built up or produced by the action of a plant or animal. Modern usage, however, defines organic compounds as those which contain carbon. Stareh, sugar, woody fiber, are examples.

25b. Inorganic compounds are such as are not produced by living organisms, as all the mineral compounds. They are found in the earth and air. Salt, potash, iron and gold, lime, are examples. 
25c. The organic matter in soils-the plant and animal remaius - is removed by burning. Let the pupil secure a cupful of wet soil and carefully weigh it on delicate scales. Then let it dry in the sun, and weigh again ; the difference in weight is

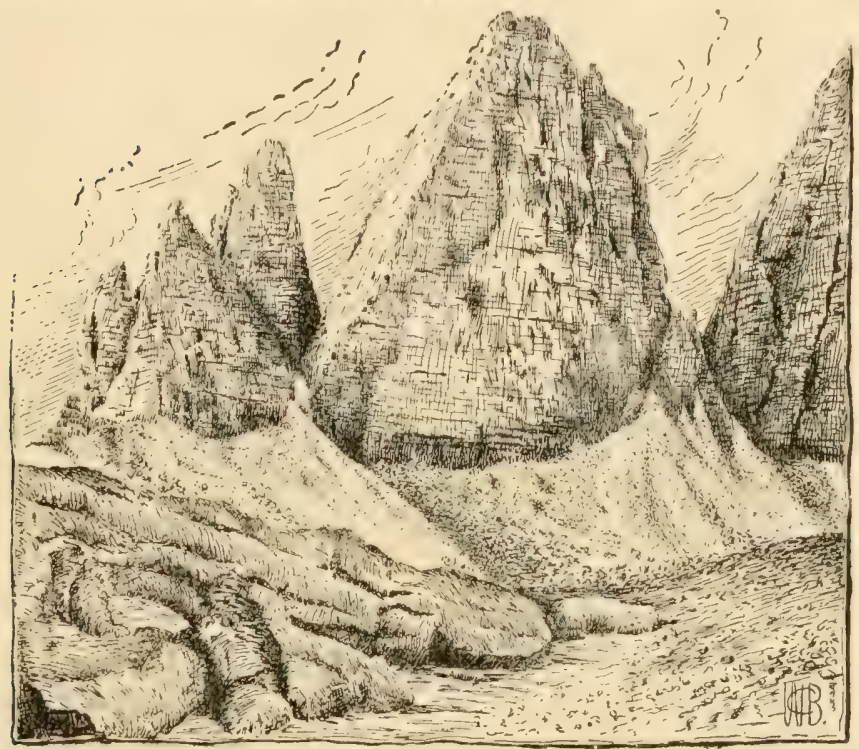

Fig. 1. Showing the wearing away of mountain peaks and the formation of soil at the base.

due to the loss or evaporation of water. Now place it in a moderately warm oven or on a stove, and after a few minutes weigh again; more of the water will now have passed off. Now thoroughly burn or bake it, and weigh ; the loss is now mostly due to the burning of the organie matter, and part of this watter has passed off as gas. If there is no perceptible loss from the burning, it is evidence that the sample contained little organic matter. Note the difference in results between clay and muck. The pupil may also be interested to try to grow plants in the baked soil. 
26a. The wearing away of rock by the weather may be observed wherever stones are exposed. Fven granite and marhlo monuments lose their polish and luster in a few years. The sharp and angular projections disalperal from the lodires and broken stones of railway euts and quarries. The pupil should look for the wear on any rocks with which he may be familiar. All stones tend to grow smaller. On a large seale, the wasting of rocks may be seen in the debris at the base of precipices and mountain peaks (Fig. 1), or wherever steep walls of rock are exposed. The palisades of the Hudson, and other precipitous river and lake bluffs, show this action well. Mountains tend to beerome roumled in tho long processes of time, although somes rocks atre of such structure that they hold their pointed shape until worn almost completely away. In Geikie's "Geological Sketches," Essay No. 8, the reader will find an interesting areount of weathering as illustrated hy the decaly of tombstones.

26b. The extent of this weathering and denuding process in the formation of soils may be graphically illustrated by the present conformation of the Alps and adjacent parts of Europe. Lubbock writes that "much of tho deposits which oceupy the valleys of the Rhine, P’o, Rhone, Reuss, Inn, and Danube-the alluvium which forms the plains of Lombardy, of Germany, of

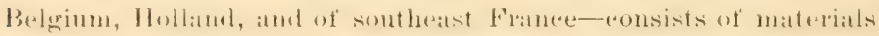
washed down from the Swiss mountains." The amount of material which has been removed from the Alps is probably "almost as great as that which still remains." So great has been the denudation that in certain eases "what is now the top of the" mountain was onee the bottom of a.valley." The Matterhorn, the boldest and one of the highest of the Alps, "is obviously a remnant of an ancient ridge," and the "present configuration of the surface [of switzerland] is indered mainly the result of denudation. * * It is certain that not a fraginent of the original surface is still in existence, though it must not be inferred that the mountains were at any time so much higher, as elevation and denudation went on together." 'There is even evidence to show that an earlier range of mountains oecupied the site of the present Alps, and that these old monntains were removed or 
worn away by denulation.- See sir .John Lubbock, "Scenery of Switzerland," Chaps. iii. and iv.

29a. Even hard surfaces of rock often support lichens, mosses, and other humble plants. "The plant is co-partner with the weather in the building of the primal soils. The lichen spreads its thin substance over the rock, sonding its fibers into the crevices and filling the chinks, as they enlarge, with the decay of its own structure; and finally the rock is fit for the moss or fern or creeping vine, each newcomer leaving its impress by which some later newcomer may profit. Finally the rock is disintegrated and comminuted, and is ready to be still further elaborated by corn and ragweed. Nature intends to leave no vacant or bare places. She providently covers the railway embankment with quack-grass or willows, and she scatters daisies in the old netalows whe re the lind has grown sick and tired of grats." -Principles of Fruit-Growing, 176.

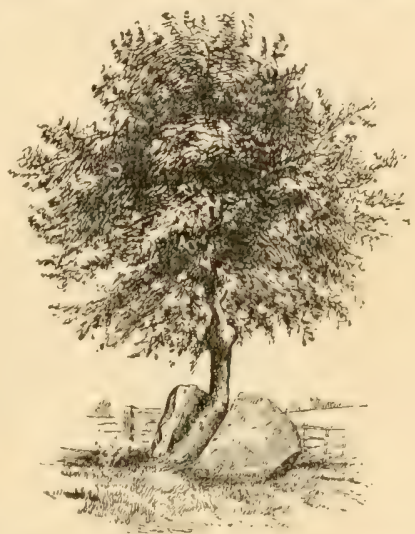

Fig. "2. The halvos of a rork fored

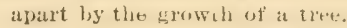

$30 a$. It is interesting to consider the general reasons for the evolution of the root. Plants were at first aquatic, and probably absorbed food from the water on all their surfaces. They may not have been attached to the earth. As they were driven into a more or loss terrestrial life by the receding of the waters and as a result of the strugrgle for existence, they developed partis which pencetrated the earth. These parts were probably only hold-fasts at first, as the roots of matuy saldwerds ale at the present time. But as it became less and less possible for the general surface of the plint to absorb food, the hold-fast sradually be came a food-gathering or fording member. - See surviral of the Unlike, pp. 41-43.

306. If the pupil has access to ledges of rock on which trees 
are growing, he will readily be able to satisfy himself that roots force open cracks and therehy split and serer the stone. Fig. 2 is an example, showing how a black cherry tree, gaining a foothold in a crevice, has erradually forced the parts of the rock

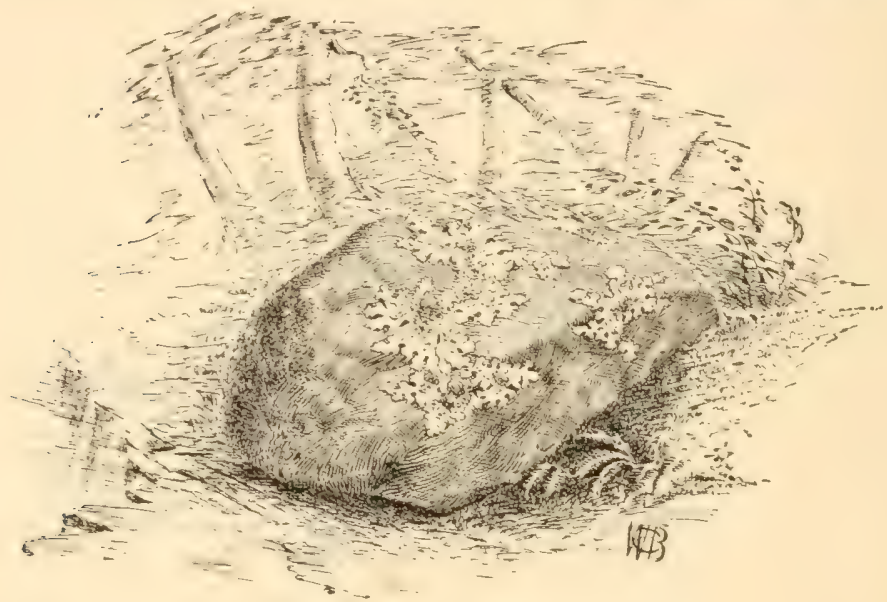

Fig. 3. Lichens have obtained a foothold.

asmuder. This particular example is the "half-way stone" between the Michigan Agricultural c'ollege and the city of Latnsing. Fig. 3 shows a stone monn which lichens have ohtained a fonthold. Any person who has worked much in a garden will have seen how roots often suround a bone, taking their food from its surface and insinuating themselves into the cracks. Roots will corrole or eat out the surface of marble. The grinding up of stones is well illustrated on any lalie shore, where the pebbles represent what is left at the present time of the stones and fragments. The rolling stones in brooks represent a similar action.

$30 c$. Bychemieal action is weant the change from which results a new chemical combination. It proluces a rearrangement of molecules. For example, the change mhich takes place when, by 
uniting lime and sulfuric acid, sulfate of lime or gypsum is produced, is chemical action.

$31 \alpha$. Knowledge of the work of the earthworm in building soils dates practically from the issue of Datrin's remarkable book, "The Formation of Vegetable Mould, through the Action of Worms," which the realer should consult for pirticulars. The subject is also ennsidered brietly in King's "Soil," Chap. i., which also diseusses the general means of soil-building.

32 . As an example of the formation of organic soils in the tropics, read accounts of the mingrove. Its mode of propagation

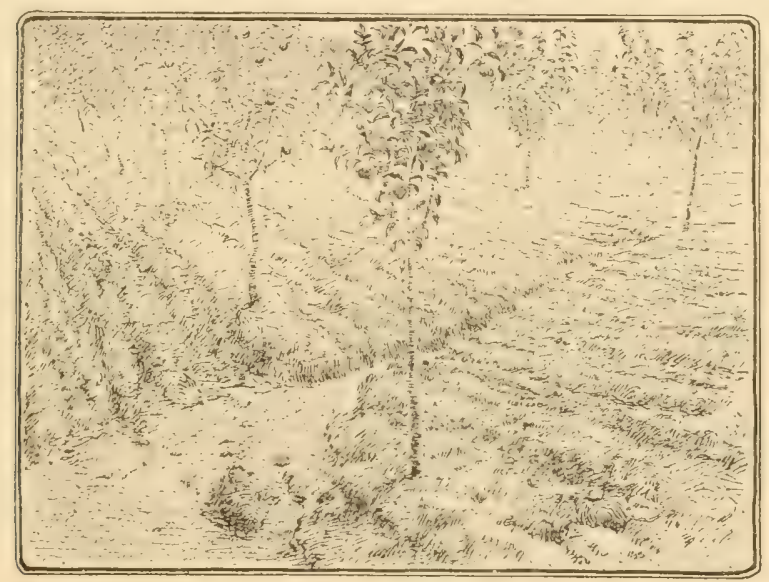

Fig, 4. A delta in an orchard.

is explatined, with illustrations, in Bailey's "Lessons with Plants," pp. 371-374; the tree is also described in Chap. $v$. of Gaye's "Great Torld's Farm." As an exumple of a formation of a peat log hy the growth of sphagnum, reald Ganong "On Raised Peathogs in New Brunswick," Botanienl Gazette, pp. 123-126, May. 1891. Sphotgnum is moss which grows in cold hogs. Nurserymen and florists use it in the packing of plants. 
33a. When spelled humus, the word is a noun; when spelled humous, it is an adjective, as "humous soils."

$34 a$. Compost is decayed or decaying organie matter which it is intended shall be applied to the land. It is usually obtained by placing leaves, sod, manure or litte: in a low flat-topped (so that it will eatch the rain) pile, and "turning it," or forking it

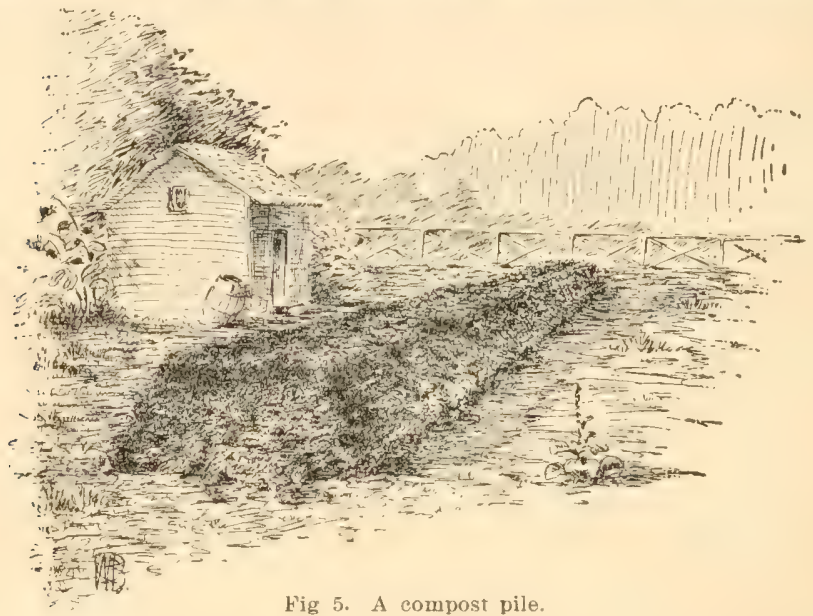

over, every few weeks, to prevent heating and to hasten uniform decomposition (Fig. 5). When the mass has passed into the condition of humus or mold (or become fine and soil-like), it is applied to the land. Composting is a most useful means of utilizing leaves, garden refuse, and other materials which ar't too coarse or "raw" to be applied directly to the land.

35a. "The term micro-organism is a general one, which includes any very inmute, microscopic form of life. More strictly speaking, the word has come to apply especially to certain forms of plant life which are too minute to be seen individually by the naked eye, and which hence require for their study the higher powers of the microscope."-Fred'k D. Chester, Bull. xl, Del. 
Exp. Sta. The terms germ, microbe, bacterium (plural bacteria), are popularly used in the same sense as miero-organism. These beings are usually unicellular (each one consisting of only a single cell). They are generally classified with plants. The róle of micro-organisms in rendering soil elements available to plants is very complex and not yet well understood. A general discussion of these organisms will be found in Lipman's "Bacteria in Relation to Country Life." The relation to germs in nitrification is briefly discussed in King's "Soil," pp. 125-134, and Roberts" "Fertility," 244-248. Fig. 6 illustrates one of the common bacteria, very much magnified. This species (Bacillus ubiquitus) is abundant in walter, air, and decaying substances.

$38 a$. Observe the deposits of sand in the quiet side (usually the concave side) of streams, and also the delts where a rapid rill flows into a slow one. When the rill flows into a rapid stream,

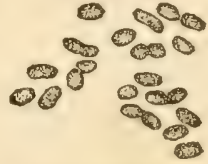

Fig. 6. Mirro-organisms, greatly magnified. the larger current earries away the deposit so that it may not be seen. Recall how sand-hars form again and again in lakes, and how streams must be frequently dredged to keep the channel open. The slower the stream the more quickly does it drop its sediment; and the more winding, also, is its course, lying in the bed of its own deposits. (See Fig. 4.)

$38 b$. Dip a glass of water from a roily stream, and observe the earth which settles to the bottom.

39a. Glaciers are still alundant in alpine and arctice regions. It was from the study of glaciers in the Alps that Agassiz conceived the hypothesis that large parts of the earth hat once been subjected to glacial action. A good popular discussion of glaciers and their action may be found in Chap. xvii. of Tarr's "Elementary Physical Geography." Delightful readings may alio be made from Agassiz's "Geological Sketches."

$40 a$. Let the pupil eatch a few rain drops on a perfectly clean and clear pane of glass, and olserve if any sediment is left when the drops have evaporated. Is there any differences in the amount. of dust brought down after a "dry spell" and after a period of rainy weather, or at the beginning and end of a shower? I'he 
pupil may now be alble to explain why the windows get dirty after a rain; and he will be interested in the streaks on the cornices of buiddings and on exposed statuary. He may havo heard that even sailing ships get dusty when at sea.

$42 a$. See Roberts' "Fertility of the Land," p. 16. Read all of Chapter i. The food which is not available, or not in condition to be used by the plant, but which may become available through good tillage or otherwise, is called potential plant-food.

$43 \alpha$. The soil is not a simple reservoir of plant-food in the condition of salt or sugar, ready to be dissolved in water and immediately taken up by roots. The soil is plant-food; but most of it must be changed in eomposition before it is available to plants; and the elements are not present in the proportions which plants require, so that much of the soil is in exess of the needs of plants and can never be used as food.

$4 \mathrm{~s} a$. For supplementary reading on the formation of soils, Chapter i. of King's "Soil" should be consulted. Most text-books of geology also treat the subject to some extent. Shaler's article on soil, in 12th Annual Report of the U. S. Geological Survey (pr. 319-34.5), is excellent. A discussion of weathering may bu found in chapter vi. of Tarr's "Elementary Geology;" and other" references are entaimed in Chapters xiii. and xxi. of his "Elementary Physical Geography." Stockbridge's "Rocks and Soils" $(1895)$ has special reference to agriculture. A readable account. of the formation of soil may be found in Chapters iii., iv. and $v$. Gaye's "Freat Word's Farm." Merrill's "Rocks, Rock-Weathering and soils" (1897) is a full seientifie discussion of the subject. Consult Hilgard's "Soils," and the text by Lyon aud Fippin; also the part on soils in Vol. I, Cyelopedia of Ameriean Agriculture. 


\section{Chapter II}

\section{THE TEX'TURE AND STRLC'TURE OF THE SOIL}

\section{What Is Meant by Texiure}

49. We have seen that the offices of the soil are of two general kinds, -it affords a physical medium in which the plant can grow (41), and it supplies materials that the plant uses in the building of its tissues (42). It cannot be said that one of these offices is more important than the other, since both are essential; but attention has been so long fixed upon the mere content of soils that it is important to emphasize the physical attributes. Crops camnot grow on a rock, no matter how much plant-food it may contain. The passing of rock into soil is a matter of change in texture and structure more than in plant-food. Texture refers to the size of the particles; structure to the arrangement of the particles.

50. The phrsical state of the soil may be spoken of as its structure, much as we speak of the structure of a house of brick or stone. The common adjectives that are applied to the ondition of agricultural soils are descriptions of its 
structure: as, mellow, hard, loose, compact, open, porous, shallow, deen, leachy, retentive, lumpy, cloddy, fine in good tilth.

.)1. Texture and structure must not be confomded with the plysical forces or operations in the soil, as the fluctuations of temperature, movements of water, circulation of air. They refer to condition or state, and are passive, not to forces or movements, which are artive; but it is upon this passive condition that the operation of both physical and chemical forces chiefly depends.

\section{IThy Good Texture and Structure are Important}

52. A finely clivided, mellow, friable soil is more productive than a hard and lumpy one of the same chemical composition, hecause: It holds and retains more moisture; holds more air; promotes nitrification; hastens the deeomposition of the mineral elements; has less variable extremes of temperature: allows a hetter root-hold to the plant; presents greater surface to the roots. In all these ways, and others, the mellowness of the soil renders the plant-fond more available, am affords a congenial and comfortahle place in which the plant may grow.

5.). Good structure (as mulerstood by the farmer) not only facilitates and hastens the physiail and chemical activities, but it also presents 
a greater feeding-surface to roots, becanse the particles of earth are very small (52). Roots feerl on the surfaces of hard particles of earth, and the feeding-area is therefore increased in proportion to the increase in the surface area of the particles. Divirling a culve into two equal parts increases its surface area ly onethird. (Dividing a cube adds two sides or surfaces.) Fining the soil may therefore be equivalent to fertilizing it, so far as plantgrowth is concerned.

\section{How Good Structure is Secured}

54. The size of the soil particles, determining the texture of the soil, camnot be morlified to any appreciable extent by ordinary farm practices. Tillage has little effect in changing the size of the ultimate particles.

55. The arrangement of the particles, which determines the structure, can be grestly changed ly farm practice. If the structure is lumpy ancl open, the soil needs pulverization; if it is rompact and hard, it neerls loosening up. Tery loose and leachy soils are usually improved if the particles, particulary in the under soil, are brought together and compacted.

56. The size of the granules (or agrregations of particles) of soils is modified by three general 
means: ( $($ ) by apply mechanical force, as in all the operations of tilling; (b) by setting at work various physical forees, as weathering (fall-plowing is a typical example), and the results following under-elraining; (c) by applying some material that acts chemically on the particles. (The first eaption, a, is illustrater in paraglaphs 26, $26,266,27,28$; and it is further explained in Chapter iv.)

57. (b) Under-drainage has two general uses, -it removes superfluous water, and improves the physical condition of the soil. The latter nse is often the more improtant. The improvement of the texture is the result, chiefly, of preventing water-soaking and of admitting air. Tmler-drainder soils become "dreper." The watertable is lowered, sinces the depth at which water stands tends to approach nearer and nearer to the depth of the dratus and thereby the plant roots are enabled to penetrate more deeply.

58. (c) Some substanees have the power to break down or to pulverize hart soils, or to bind together loose ones, or otherwise to modify the structure. Surh materials-whirh are applied for their remote or serombary chemieal effectsare caller amemoments. Lime is a typical example. Quick-lime is known to make clay lands mellow, and it is smplosed to eoment or hind together the bartielese of simele or eravels. Most 
chemical fertilizers are both amendments and direct fertilizers, since they modify the structure of the soil as well as adil plant-food to it.

59. The extraneous or supplementary materials (54) which directly morlify the structure of soils are those that make humms (.3:i), as green-manures, farm-manmres, and the like. Stable-manure is usually more important in improving soil structure than in directly supplying plant-food.

\section{Structure and Manures}

60. We have now seen that the farmer should give attention to the structure of his soil before he worries about its richness The conritions must first be marle fit or comfortable for the growing of plants: then the stimulus of special or high feeding may be applied. But manures and fertilizers may aid in securing this good structure at the same time that they ard plant-food. Tet fertilizer, howerer rich, may be applied to soils wholly withont avail; and the best results from condensed ol chemical fertilizers are usually secured on soils that are in the best tilth. That is, it is almost useless to apply commercial fortilizers to lauds that are not in proper physical condition for the best growth of crops. 


\section{SUGGESTIONS ON CHAPTER II}

49a. The following extraets from Bulletin 119 of the Cornell Experiment Station illustrate the subject under diseussion: "The other day, I secured one sample of soil from a very hard clay knoll upon which beans had been planted, but in which they were almost mable to germinate; another sample from a

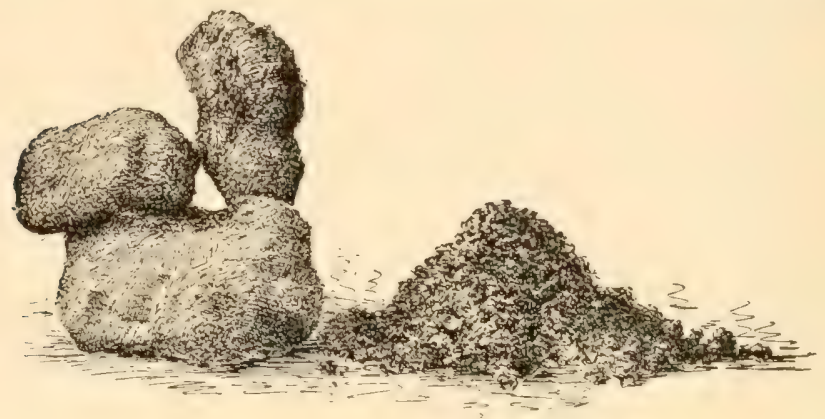

Fig. 7. Examples of poor and good texture.

contiguous soil, in which beans were growing luxuriantly; and, as a third sample, I chipped a piece of rock off my house, which is built of stone of the neirhborhood. All of these samples were taken to the chemist for analysis. The samples of soil which were actually taken to the chemist are shown in Fig. 7 . The rock (sample III), was hard native stone."

The figures give the percentages of some of the leading constituents in the three materials.

\begin{tabular}{|c|c|c|c|c|c|c|}
\hline & Moisture & Nitroyen & $\begin{array}{c}\text { Phosphoric } \\
\text { acid }\end{array}$ & Potash & Lime & $\begin{array}{c}\text { Organic } \\
\text { matter }\end{array}$ \\
\hline I. $\mathrm{U}$ & 13.25 & .08 & .20 & 1.1 & .41 & 3.19 \\
\hline II. Good bean land..... & 15.95 & .11 & .17 & .75 & .61 & 5.45 \\
\hline II. Rock ............... & . ....... & ....... & .08 & 2.12 & 2.55 & \\
\hline
\end{tabular}

"In other words, the chemist says that the poorer soil-the one upon which I cannot grow heans-is the richer in mineral 
plant-food, and that the rock contains a most abundant supply of potash and about half as much phosphoric acid as the good bean soil.

"All this, after all, is not surprising, when we come to think of it. Every good farmer knows that a hard and lumpy soil will not grow good crops, no matter how much plant-food it. may contain. A clay soil which has been producing good crops for any number of years may be so seriously injured by one injudicious plowing in a wet time as to ruin it for the growing of erops for two or three years. The injury lies in the modification of its physical structure, not in the lessening of its plint-food. A saudy soil may also be seriously impaired for the growing of any erop if the humus, or decaying organic matter, is allowed to burn out of it. It then becomes leachy, it quickly loses its moisture, and it becomes excessively liot in bricht sunny weather. Similar remarks may he applied to all soils. That is, the terture and structure or physical condition of the soll is nearly always more important than its mere richness in plant-food.

"The first step in the enrichment of unproductive land is to improve its physical condition by means of careful and thorough tillage, hy the adrlition of humus, and, perhaps, hy under-drainage. It must first ho put in such condition that plants "an grow in it. After that, the addition of chemical fertilizers may pay by giving additional or redundant growth."

$53 a$. Read Chapter ii. in King's "Soil." The following is quoted from that work, p. 72: "Suppose we take a marble exactly one inch in diameter. It will just slip inside a cube one inch on a side, and will hold a film of water 3.1416 square inches in area. But reduce the diameters of the marbles to onetenth of an inch, and at least 1,000 of them will be required to fill the cubie inch, and their aggregate surface area will be 31.416 square inches. If, however, the diameters of these spheres be reduced to one-hundredth of an inch, 1,000,000 of them will be required to make a cubic inch, and their total surface area will then be 314.16 square inches. Suppose, again, the soil particles to have a diameter of one-thousandth of an inch. It 
will then reppiare 1,000,000,000 of them to eompletely fill the cubie inch, whilo thoir aggrogate surface aroa must moasure 3141.59 square inches."

536. Another illustration may bo taken ("'lexturo of Soil and Conservation of Moisturo," being a first lesson in tho Cornoll farmor's rouding courso): "Lot us suppose the soil in ono of your plowed fields is in littlo lumps of the uniform sizo of inch eubes-that is, ono square inch on each side of the cubo. Hlow many square inches of surfice has that cube exposed to root contact and moisture film? Now imarino that ono of these inch cubes is broken up into smaller enbes measuring one-pighth of an inch,- how many squaro inches of surface will you now have exposed to root contact and film moisture? Now reflect what you have dono in breaking up tho inch eubo of earth. Tho amount of oarth has not beon inereased ono atom; yet, by fining it, you havo incroased just eight times tho root pasturago and surface for water film. 'Tho practical point of this lesson is that hy superiot tillago you can expand ono acro into eight, or hy neglectful mangement oight reres ean bo redueed to one. It. also domonstrates why a skillful farmer ean produce as much lrom difty acres as a careless one can from four humdred, and also confirms tho assortion that suceoss in modern agrieulture depends more on the size of the farner than upon the size of the farm."

536. 'This funing or dividing of' the soil, therefore, increases the fecding area for roots; or, as Jethro 'lull said, it extends the "pot pasturage." "Tho value of simple tillage or fining of the land as a mouns of ineroasing its productivity was first elearly set forth in 1733 by Jethro 'l'ull, in his "Now Ilorse Hooing IIusbimdry.' 'l'ho promises upon which 'l'ull founded his system aro orroneous. IIo supposed that plant roots actually take in or absorb the fino particles of the earh, and, therefore, the finer and more numerous these particles the moro luxuriantly the plant will grow. Jlis system of tillago, however, was correct, and his oxperiments and writings have had a most profound influenco. If only one book of all the thousands which have been written on

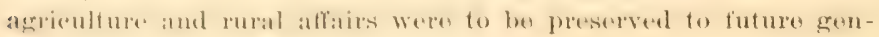




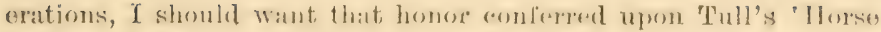

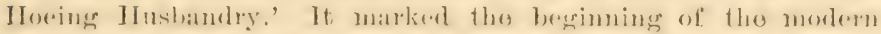

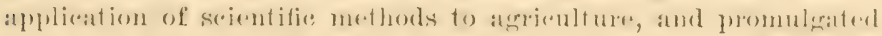
a system of treatment of the lamel which, in its essential prinei-

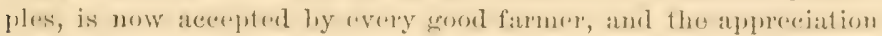
of which must increase to the end of time."-Bailcy, Bull. 119, Comell Lxp. Sta. 'lull died in 1740 .

57a. "The actual contom of the water-table in an under-

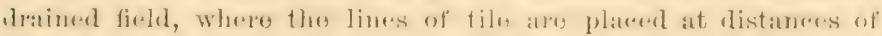

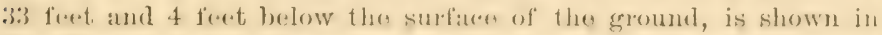

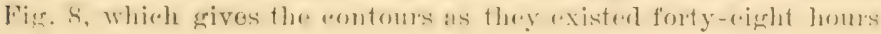

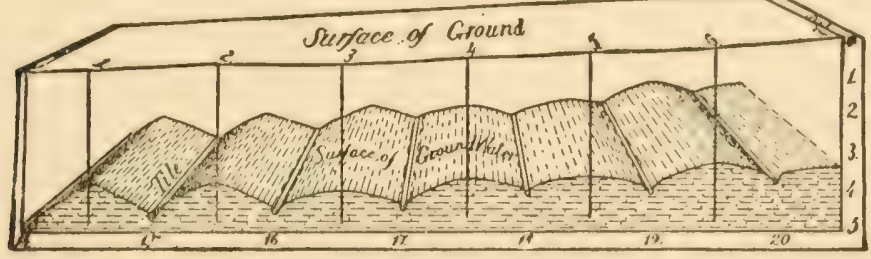

Fig. 8. Showing the actual contour of tho water-tiblo in a tilo-drained field.

after a rainfall of .87 inches. In this caso the height of the water midway between the lines of tile variod from 4 inches to 12 inches above the tops of the tile."-King, The Soil, 7.259.

58a. Read Roberts" "Fertility of the Land," pp. 303-312, on 1ho physical efferts of liming lame ; also "The soil," [). 30, and Whereler's "Isiming of Soils," Farmers" Bulletin No. 77, U. S. 1)ent. Agrice. The eflects of lime in flocenlating or mellowing clay may bo observed by working up a ball of stift elay with common water and a similar ball with limo water; the former will heromo hatrd on drying, but the lattre will readily fall to pienes. Jime water maty lw mate by shaking up a lump of lime, in a bottle of water.

$60 a$. One of the most foreible illustrations of the value of fine texture of soil is afforded by the result which the florist 
obtains in pots. He mixes and sifts his soils so that it is all ameuable to root action, and he is able to raise a larger plant from a handful of soil than the general farmer grows from a half bushel. See Fig. 9.

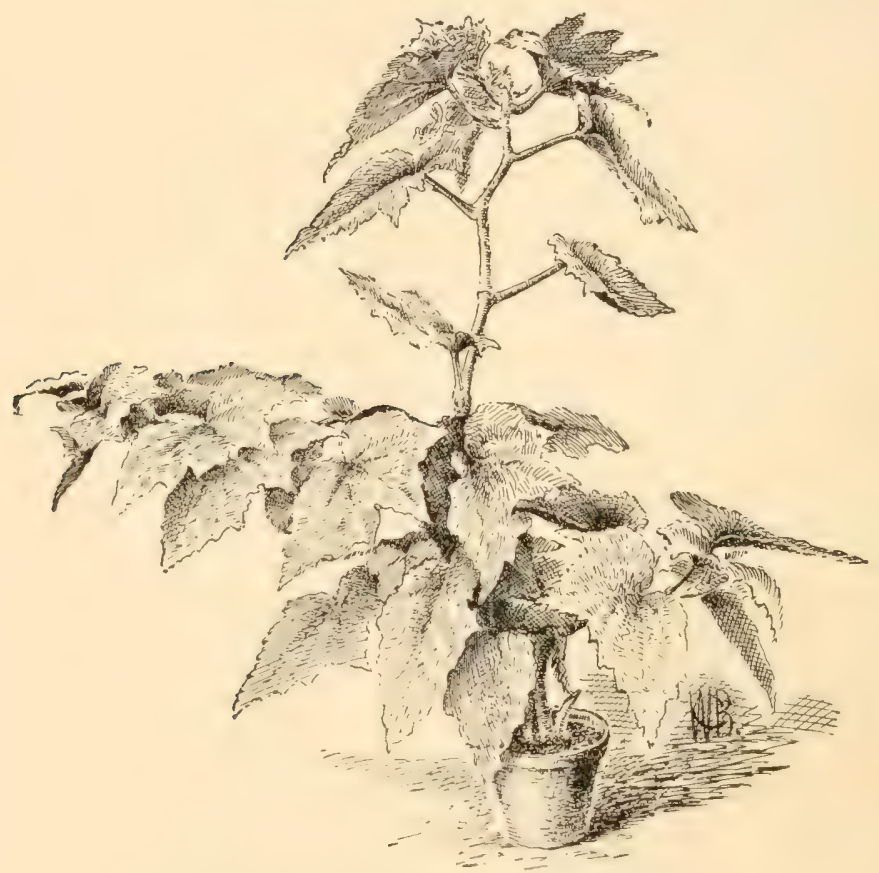

F'ig. 9. Showiug the possibilities of at potful of soil. 


\title{
Chapter III
}

\section{THE MOISTURE IN THE SOIL}

\author{
L. A. CLINTON
}

\section{Why Moisture Is Important}

61. However much plant-food there may be in the soil, plants camnot grow without the presence of water. Water is needed for three purposes: to dissolve the plant-food and thereby enable it to enter the plant; to contribute to the building of plant tissue and to the maintenance of the life of the plant; and to regulate temperature.

6.2. A consideration of the amount of water required by plants in their growth shows why supplying plant-food alone does not insure the success of the erop. The amount of water used by some of the common erops in their development to maturity is approximately as follows:

Corn ... . 50 bus. per acre requires 1,500,000 lbs. of water. Potatoes.. 200 bus. Oats ... 29 bus.

$1,268,000 \mathrm{lbs}$. $1,192,000$ lbs.

63. The failure of crops is more frequently due to improper control of moisture than to any 
other one atuse. In eestatin seretions of the commtry irrigation is suceessifully amployed; but mest fammers must depend on the rainfall as the whicf somere for the supply of moisture.

\section{How Water Is Held in the Soil}

tit. 'The watere in the soil may be in one of

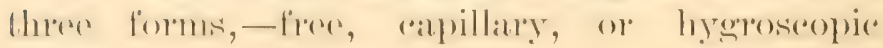
water.

(35.) 'The frese water of the soil is that whech flows molere the inflenene of enrarity. It is this water which is remosed in part hy drains, and which is the somere of supply for wells and springs. It is not utilized directly by entivated plants, but it is valualble when removed a

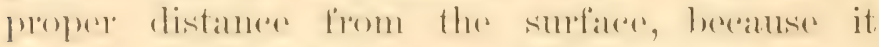
servers als a reservoil from which mojisture may be krawn by capillary action.

6iti. Cappllatry water is that which is hede by anllesion to the soil partieles, or in the interstiens of openinges between the partieles. It is not antrolled of influmered hy gravity, but palsoses from one part of the soil to another, temeling to kerpe the soil in equilibrium (or in milorm romelition) so lall as its moisture is romeremed. Ther eapillatry water is the direct supply lor plants, and it is this which should le most carefully provided for and saved. 
67. Hyeroscopic water is that which is held firmly as a film surrounding ateh particle of soil. It does not move uncler the influence of gravity or capillarity, and it is held so fimmly that it is driven off only when the soil is exposed to a temperature of $22^{\circ}$ Fahr. The dryest roard-rlust firmly holds its hygroseopic water, and it maly constitute from '2 to 3 per cent or more of the weight of the soil. If of service to plants in any way, it is only during the most excessive droughts, in which ease it may sustain the plants for a time, until capillary water is supplied.

68. Both capillary amel hygroseopic water are frempently reforred to as "film moisture," from the fact that they are hold as a film of greater or less thickness aromel the soil particles. That part which has the inost intinate and permanent contaret with the particle is the hygroscopice water, and the onter part of the film, which may move away from the soil particle, is the capillary water. Vory wet limel is that which contains too nuch free water ; whereas, soils which are dryish and erumbly usually contain sufficient water for the growing of plants. That is, lamels in gool condition for the growing of ropss are moist, not wet; and we may, therefore, speak of the moisture of the soil rather than the water of the soil. 
69. The free water of the soil is found at varying depths. Frequently it comes to the surface and oozes out as springs. Again it is many feet below the surface. The supply is maintained by rainfall, that part which is not held by eapillary attraction or removed by surface drainage passing down to the level of the free water. In soils which are very porous and open, as gravelly soils, a large part of the rainfall passes down quickly, and such soils are said to be "leachy." With soils that are fine and compact and impervions, as in many clays, the water runs off by surface drainage, and not only is the supply of capillary water not increased to any perceptible degree, but the surface flowing removes valuable plant-food, riluses resion, and increases dangers from flools. Under these cirrumstances rainfall may be a detriment.

3. How the Moisture-holding Capacity of the Soil May be Increased.

3a. The capacity of the soil

70. The first step toward utilizing the water of the soil is to so fit the land that the rainfall may be stored. In the winter months a large percentage of the rainfall is removed by surface 
drainage, and in the summer months by evaporation. The soil should be put into such condition in the fall that it can rearlily absorly the winter rainfall. If the surface is hard, smooth and compacted, as is often the case with clay soils, it should be loosened with the plow and he left rough and meven. If there is danger of surface erosion or washing, some quick-germinating seed (as rye or pea) may be sown in early fall. The plants prevent the rain from flowing away rapidly, and the roots bind the particles of soil in place.

71. The capacity of the soil to hold water' depends upon its original constitution (whether clay, loam, sand, ete.) and upon the treatment which it has received. If the humus or decaying organic matter has beeli depleted, its moisture-holding rapacity is diminisherl.

72. The rapacity of the different soils to hold rapillary and hygroseopic water (when clried at a temperature of $144^{\circ}$ ) is shown by the following-table:

\begin{tabular}{|c|c|c|c|}
\hline Kind of soil & $\begin{array}{c}\text { Per cent (by weight) } \\
\text { of moisture held } \\
\text { in soil }\end{array}$ & $\begin{array}{l}\text { Per cent (by vol- } \\
\text { ume) held in } \\
\text { soil }\end{array}$ & $\begin{array}{l}\text { Pounds of water } \\
\text { in } 1 \mathrm{cu} . \mathrm{ft} . \\
\text { of soil }\end{array}$ \\
\hline Silicious sand & . . 25 & 37.9 & 27.3 \\
\hline Sandy elay . & . . 40 & 51.4 & 38.8 \\
\hline Loamy clay . . & . . 50 & 57.3 & 41.4 \\
\hline Stiff brick-clay & . . 61 & 62.9 & 45.4 \\
\hline Humus . . &. .181 & 69.8 & 50.1 \\
\hline Garden mold & . . . 89 & 67.3 & 48.4 \\
\hline
\end{tabular}


3b. Capacity is increased by the addition of humus

73. A study of the above table reveals the fact that the humous soil (:33) far exceeds any of the others in its ability to hold moisture. By long-eontinued cropping and tilling, without making proper returns in the way of greenmanures or barn-manures, the humus may be so reduced that the soil consists very largely of mineral matter. One reason why newly cleared lands frequently give more satisfactory returns than lands which have been long cropped, is that the fresh land is rich in humus. The soil is eonsequently open and porous, and the rain which falls is quickly absorbed, and is largely retained as capillary or hygroscopic water.

7t. The humus of the soil may be gradually increased by plowing under green-crops, by the nse of harn-manures, by using cover-crops during the late summer and fall and plowing them under in the spring before they have used up the moisture which should be saved for the succeeding crop. These practices can be overdone, however, and the soil made so loose and open that the winds cause it to dry out quickly, and the power of clrawing moisture from the stores of free water will be greatly lessened. 
3c. Capacity may be increased by under-drainage

75. Drainage has an intimate relation to soil moisture. By drainage is meant the means employed for the removal of the surplus free water. Surface or open ditehes may serve as conduits to carry off surface water, but as soil drains they are failures. The correct method for removing the surplus water of rainfall is to cause it to sink into the soil and be removerl by under-drains. That which is remored by surface flow fails to impart any beneficial effect to the soil (69).

76. Lands which are well under-drained are porous. The rain which falls upon them passes down quickly, and is not removed by surfaces flow. It is removed only when the level of the free water rises to the level of the drain. By observing the action of drains which are of different depths, it has heen found that after a protracted drought the drains which begin to flow first are those which are at the greatest repth, showing that as the level of the free water rises to the rrain the flow begins, and that it is not remored to any considerable extent in its downward passage.

77. The sinking of the water through the soil does more good than merely to supply moisture. In the spring the rain is warmer than the soil, 
and in passing down it gives up some of its heat, and the soil temperature is thereby raised. In the summer the rain is the cooler, and the soil parts with some of its heat. On lands which have been thoroughly under-slrained, crops are far better able to withstand drought than those on land which needs drainage.

78. Few cultivated plants can thrive with their roots in free water. When the free water is near the surface, it is injurious in several ways: it limits the feeding space; it makes the soil cold in spring; it orempies the space which should be filled with air ; it causes plant-food to be locked up; it dilutes the plant-food in solufion; it prevents the action of micro-organisms; it causes the rainfall to be carried off largely by surface drainage. Thorough under-drainage tends to remove all these unfavorable conditions. If there is 110 effective under-drainage, either by natural or artificial channels, the water must escape by surface evaporation.

\section{3d. The caparity is increased by proper tillage}

79. Tillage enables soils to hold moisture hy two means: by increasing the depth of the soil in which the plants can grow (that is, by increasing the depth of the reservoir), and by increasing the capillary power of the soil. We 
have already seen $(57,75-78)$ that draining inrreases the depth of the soil ; so does deep plowing. Capillarity is increased by finely dividing or pulverizing the soil.

80. Increasing the capillarity increases the moisture-holding capacity of soils in two ways: it enables the soil to actually hold more moisture per square inch; it ellables it to draw up moisture from the free water of the lower subsoil (65).

81. By the action of capillary attraction, moisture mores from one layer of soil to another (66), usually from the lower to the upper, to supply the place of that which has been used hy plants, or which has been lost by evaporation. The rapidity of movement and the force with which it is held depend upon various conditions. A soil in which the particles are somewhat large, as in sandy or gravelly soils, may, if well compacted, show considerable rapidity of movement, but weak power to retain moisture. The finer the division of the soil particles the greater is the surface presented. In finely divided clay soils, the movement of capillary water is slow but the retaining power is great. Occasionally it happens that the particles are so fine that the spaces disappear, and there is producerl a condition through which moisture and air cammot pass. This state of 
affairs is produed when elay soils are "puddled." It is evident, therefore, that soils which are either very loose or exceserlingly finely pulverized are not in the best eondition for the holding of moisture; lut the dinnger of orer-pulverizing is very small.

\section{The Conservation of Moisture}

82. By consorvation of moisture is meant the prevention of all umneressary waste of the capillary water of the soil, either through weeds or by evaporation. It is the saring and utilizing of moisture. The object is to make the water which seroks to ascalpe from the surfaree pass through the allivitud plants. Plants require that their foorl be in solution. The moisture of the soil contains plant-food in solution. If this moisture is permitted to esealpe from the surfier ly evaporation, it leaves the plant-food at the surface. This food amnot nourish plants, because it is out of the range of their lesding roots. If the escape of the moisture is thromgh the plants, there is created a moisture curpent towards the ronts, and the plant-forel is carried where it ean be used to advantage.

8.3. Moisture rapirly rises to the surface ly calpillarity, to replace that which has evapo- 
rated or has heren used by plants, if the soil is in proper physical eomdition. Mrasmess should be adopted to provent this moisture from being lost hy (valporation. The most prarotical and effective mothorl is lo astablishing and maintaining a surfares mulele of soil. By lore quent nse of implements of tillages, which loosem the soil to a depth of two or there inches, this muleh may be proserverel and the moisture saved. 'Tho drier and looser this mulch, the more effective it is. This dry and loose surface breaks the capillarv connection lestween the aiv and the moist mulni-soil, and has the effect of interposing a foreign lubly betweres the atmosphere and the rarth. A hoard or a blanket laid on the earth has the samo effect, and the soil is moist bomoath it. T'his soil-muleh should be renewed, or reprired, in the growing srason, as often as if heomes hard or baked, by means of shallow tillage.

\section{SUGGESTIONS ON CHAPTER III}

62c. To show that growing plants are eonstantly giving off large quantities of water through their foliage, grow corn, beans or squashes in rich soil in a flower-pot. Orer the soil in the pot should he pliaced a rubler or oiled eloth covering, so that no mosture citn come from this souree. Then over the plant place a chlass hell-jatr or a common fruit-jar, and notico how rapidly the moisture collents on the interior of the jar (Fig. 10). This expernoent maly he conducted even better in the field. 
63a. Irrigation is of primary value, of course, in all arid countries; but as complete systems of land culture develop, it must be employed also in counfries of free rainfall in order to tide over periols of drought and to enable the husbaudman to control his eonditions. Irrigation will come more and more to be a truly national nroblem.

66a. Capillary action, or capillarity, is due to the attraction of matter for matter. Capillary attraction is that foree which

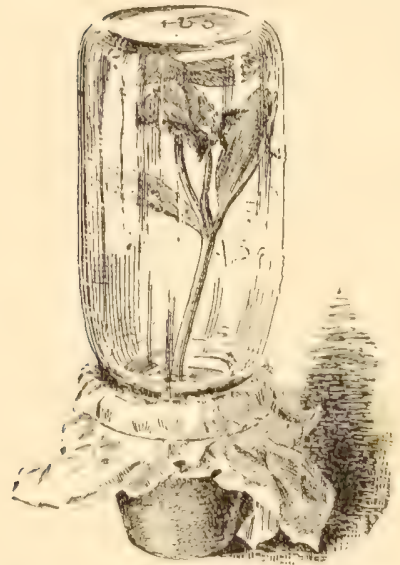

Fig. 10. How to show that plants give off moisture.

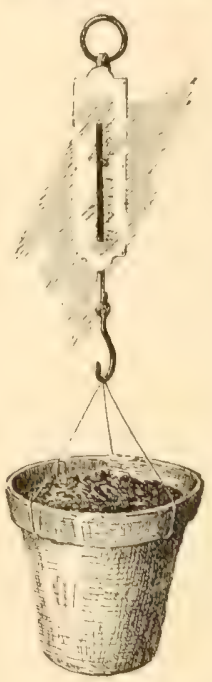

Fig. 11. To determine how much. water a soil can hold.

causes a liquid to ascend or deseend or move laterally through very small openings or tubes, or the interstices hetween fine particles of solicl matter, or by which it is hele to the surface of the particles themselves. The teacher' should illustrate capillarity by the familiar experiment of standing tubes of glass in water. The smaller the bore of the tuhe, the higher the water rises. The oil risog in the wick by meaus of eaplliarity. The principlo may be 
illustrated hy filling straight (or alrand) lamp chimneys with compacted dry soil and standing them in a dish of wator.

68a. Film moisture can be illustrated by dipping a marble into water aud observing the skin or film of moisture adhering to all sirles. The most siltisfactory conditions of soil moisture rxist. when each soil grain is covered by a film of water. The characterl of film moisture is ehanged by the thickness of the film. The thicker the film, the less the tension to the body, until it beromes so thick as to separate from that body and berome at drop of water; and it is then subject to the law of eravitation, and can travel but in one direction-downward. While in a state of film moisture, it is amenable to the law of capillary attraction, and ran move in any direction, which means that it goes towards the thimnest films. The readiness with which water films travel ran be seen by dipping a piece of enbe sugar into coffer and observing how quickly the liquid pervades the lump of sugar. That soil moisture may move with the same facility as the coffee does in the sugar, it is necessary to have the soil grains in proper touch one with another;-not so far apart but that the water films can reach one to the other, not so close as to imperle the progress of the films. The two extremes in soil ran be seen in loose gravel and hard clay.

70a. By rainfall is meant precipitation, - the fall of water in any form, as in rain, snow and hail.

72a. That different soils vary in their capacity to hold moisture may be illustrated hy the following experiment: Provide several flower-pots of the same size and shape. The various soils should be thoroughly dried in an oven. At least four kimks of soil should be trested: gravel, sand, clay, and garden loam. Place an equal weight of each soil in the pots. Sinspend one of the pots from a rommon spring-seales (Fig. 11). Notice the number of pounds and ounces registered. Now slowly pour water upon the soil until it is thoroughly saturated. Cover with a piece of oiled eloth or oiled paper, and allow it to drain until no more water will flow from it. The water which drains from the pot is the free water. Tho difference in weight of the pot of soil before soaking, and after the drainage, shows the amount of water held by capillarity. 
74a. The plowing under of green-crops sometimes gives unsatisfactory results. If a heary growth is plowed under when the soil does not contain sufficient moisture to cause ready decomposition, this layer of foreign

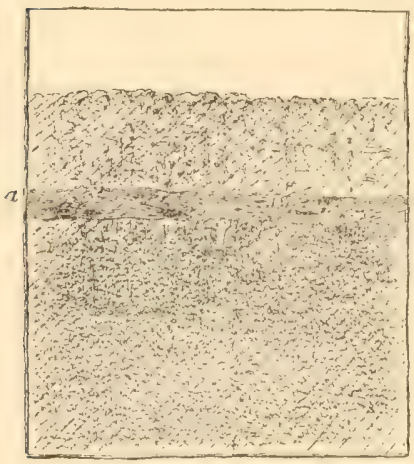

Fig. 12. The layer $(a b)$ of undecomposed herbage. matter prevents the passage of the water from the subsoil to the surface soil (Fig. 12). The crop which is then planted must neeessarily feed for some time in the $h$ surface soil, and in case of prolonged drought a partial or complete failure of the crop may result. Heavy growths of covercrops, as well as coarse, strawy manures, should be plowed under when there is sufficient moisture in the soil to cause decomposition. In case it is necessary to plow them under when the soil is dry,

a heavy roller will so compact the soil that eapillarity will be in part restored and decomposition hastened.

$75 a$. While surface drains are to be avoided, yet it frequently becomes necessary to provide a conduit or open ditch into which tile drains may open, or to remove flood water. It is a common error to have the banks too vertical. 'Through the action of frost or the tramping of stock, the banks are constantly requiring attention. 'The ditch should be wide, and the banks should have a gradual slope, as illustrated in Fig. 13. Grass-seed should be sown over the sides and bottom, so that the sod will prevent washing. One can drive across such a ditch. When possible, this ditch would be made the boundary of a field, or be placed near a fence.

$76 a$. The depth at which tile drains should be placed must be determined by the nature of the soil. In very compact and impervious soils, as clay, the drains must be eloser together and nearer the surface than in porous soils. Land may become so 
hard upon the surface that the water of rainfall never can pass down. By placing the drains shallow, the soil is rendered mellow and porous, water passes down readily, the level of free water is raised, and the surplus is removed.

76b. The distance apart at which draius should lue placed is variable, hut 30 feet is usually considered most adrisuble. The

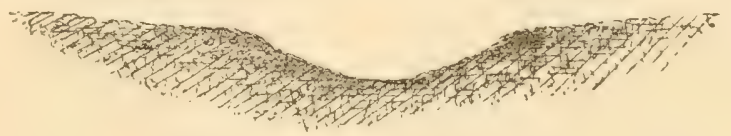

Fig. 13. Properly made open ditch.

level of the free water tends to rise higher at a point midway between drains, as shown in Fig. 8. If the drains are too far apart, this tendeney may he greater thin the tendency to move toward the drain. In soils through which the water moves somewhat readily, the drains may he farther removed than in close, impervious soils.

78a. In the spring, on undrained soils, free water remains for a considerable time near the surfice: consefuently the plant

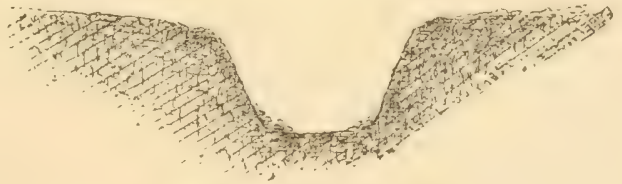

Fig. 11. Sirkes tonsteep.

roots cannot penetrate de+enly into the soil. When the drought comes the surface is first affecterl, and the plants suffer at once. It is a well-known fact that tap-rooted plants are admirably fitted to withstand dry weather. Their feerlers are deej) in the soil. It is this condition which is ohtained to a certain extent by under-drainage. The soil above the drain is made porous, the water which annot he held hy apillarity is quickly removed, the air penetrates, the soil becomes warm and congenal. Thus 


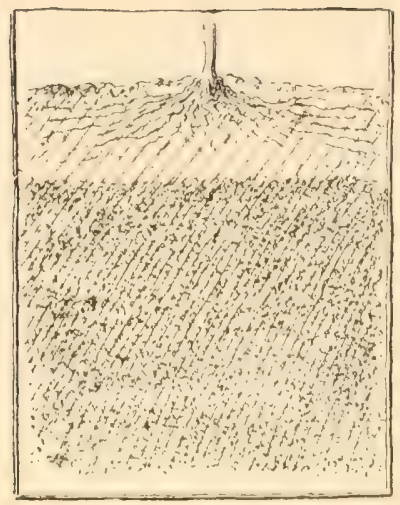

Fig. 15. Showing the condition which prevails in spring on cold, undrained soils, when the water-table is ton high.

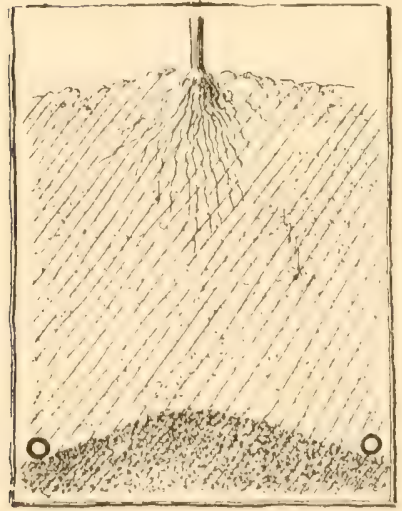

Fig. 17. On well-drained soils, the roots strike downwards.

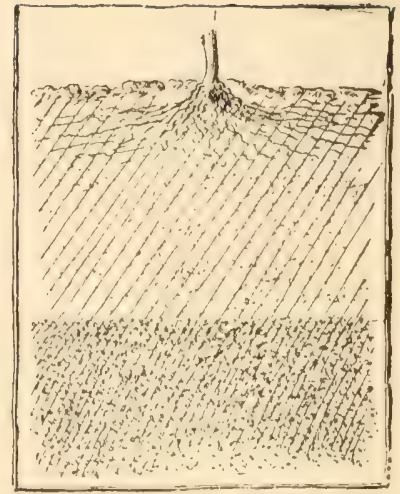

Fig. 16. When the drought comes, the plant is still shallow-rooted, sund it suffers.

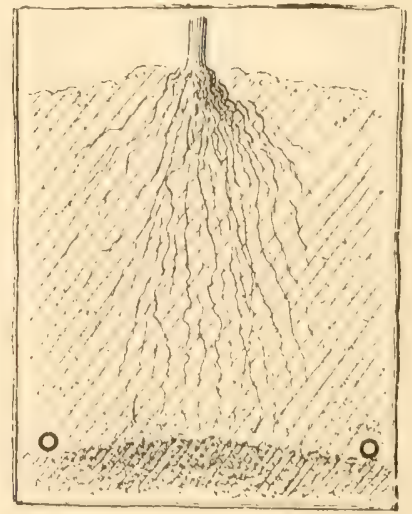

Fig 18. When the drought comes, the plant does not suffer. 
plants ane emabiled arly in their growth to sand their roots down, and when drought comes they are not seriously injured. liges. 15-18 illustrate this.

79a. The soil reservoir may be understood by likening it to a pan. A two-inch rainfall fills an inch-deep pan and runs it over; but if the depth is increased to two inches, none of the rain escapes. 'The hard-pan or water-table is the bottom of the soil reservoir. If this bottom is within a few inches of the surface, the ordinaty rainfalls fill the soil so full that it is mudely, and some of the water may be lost by surface washing. Deep plowing lowers the bottom of the reservoir, and the soil holds more water and yet remains drier.

sla. Tillage operations should vary aceording to the nature of the soil. Those soils which are loose and porous should be compacted after plowing, so that the capillary connection may be restored between the surface and the subsoil. The roller may be used. With finely divided soils, which have a tendency to become too compact, only so much tillage should be given as is necessary to produce the proper degree of pulverization. It is possible to so compact and fine some soils, as clays, that the spaces between tho soil particles is filled, and a condition is produced which prevents the rise of moisture by catpillarity, and also prevents the absorption of rainfall athd the passage of air.

816. Of general farm crops, ahout three hundred pounds of water is used in the production of one pound of dry matter. An imeh of rainfall weishs, apporimately, one humberl and thirteen and one-half tons to the aere 'l'he student will discover that the rainfall of the growiun months may not be sufticitat to supuly the erop; hence the necessity of saving the rainfall of winter and spring.

$83 a$. On the general subject of soil moisture and its conservation, read Chaps. v. and vi. in King's "Soil," and Chap. iv. in Roburts" "Fertility of the Land." Also consult publications of the Experiment Stations and U. S. Department of Agriculture: and part 3 in Vol. I of Creinperbia of Anerican Aerriculture; also the recent soil books of Hilgard, and of Lyon and Fippin. 


\section{Chapter IV}

\section{THE TILLAGE OF 'IHE SOIL}

\section{What Tillage Is}

84. We have found $(52,79)$ that tillage is onc of the means of improving the physical conrlition of the soil. By tillage is meant the stirring of the soil for the purpose of facilitating the growth of plants.

si). IVe maty divide tillage into two general kinds, - tillage which covers the entire ground, and tillage which covers only that part of the spomel which lies between the plants. The former we may eall open or general tillage, and the latter inter-tillage. Te practice open tillage before the seed is somm: it therefore prepares the land for the erop. We practice inter-tillage in fruit plantations and between the rows of rops: it therefore maintains the condition of the soil.

86. We may also speak of tillage as deep or shallow. In a general way, tillage is deep when it extends more than six inches into the ground. We also speak of surface tillage, when the 
stirring is confinerl to the one, two or three uppermost inches of the soil.

\section{What Tillage Does}

87. Tillage improves the physical rondition of the soil: hy fining the soil and extending the feeding area for roots (5i3); hy increasing the depth of the soil, or loosenimg it, so that plants olstain a deeper root-hold; hy causing the soil to dry ont and wam up in springe; by making the conditions of moisture and temperatures more mniform throughout the growing season.

88. It aids in the saving of moisture: by increasing the water-holding capareity of the soil, or deepening the reservoir (79); by cherking the evaporation (or conserving, or salving, moisture) by means of the surfare-mulch (83). The former is the result of deep tillage, as deep plowing, and the latter of surface tillage.

89. It hastens and angments rhemical arotion in the soil: loy aiding to set frese plant-food; by promoting nitrification (('ha]. vi.); by atmitting air to the soil ; by lessening extremes of temperature; by hastening the deromenosition of organie matter, as of ereen-copses or stable mammes which are plowed mmlex; hy extemling all these benefits to greater depths in the soil. In a very important sense, tillage is manure. 


\section{How Tillage Is Performed}

3a. By deep-working tools

90. Plowing. TVe plow (a) to get the land in fit condition for planting, (b) to pulverize the soil, (c) to turn under manures, green-crops, and trash, (d) to deepen the soil, and thereby increase its storage capacity for water and extend the root pasturage, (e) to break up or to form a hard-pan, $(f)$ to warm and dry the land, (a) to allow the weather to act on the soil. Passing over the first subject $(a)$, we may explain the remaining objects of plowing.

91. (b) Plowing is the most efficient means of pulverizing the soil. That is, it is not enough that the soil be inverted: it must be gromud and broken. For purposes of pulverization, the shape of the plow should he such as to twist the furrow-slice, causing it to break and (rumble as it falls. The moldboard, therefore, should have a sharp, bold outward curve at its upper extremity; and the furrow-slice should be left in an inclined, or 'ven nearly perpendicular position, rather than turned orer flat.

92. (c) Since it is important that organic matter, as manures, shall quickly decay when turned under, the plowing should be done when the season is moist, as in early spring or in fall. 
Clover and rye are also apt to become too hard and dry if allowed to grow to maturity. Herbage which does not decay quickly when plowed down may seriously injure the crop for that season $(74 a)$. For the covering of herbage, the furrow should be broad and deep; and if the land is to be surface-tilled shortly after the plowing, care should be taken that the furrowslice turns down rather flat, so as to completely cover the plants.

93. (d) The deeper the plowing, the greater the water-storage reservoir will be, other things being equal; but the plowing may be so very deep as to bring the unproductive subsoil to the surface, in which case the increase of storage capacity may be overbalanced by the loss of available fertility. On most soils and for most crops, eight or nine inches is a sufficient depth for the plow. Shallow soils are both too dry and too wet. They are too dry, because much of the rainfall is lost in surface chainage or by very rapid evaporation. They are too wet after every hard rain, becanse the water is held near the surface $(79 a)$.

94. ( $\rho)$ If a hard-pan is near the surface, deep plowing will break it ul, although the most permauent remedy may be under-drainage. In very porous soils, however, it may be necessary to form a hard-pan in order to prevent 
lomphing. This is dome ly plowing at the same

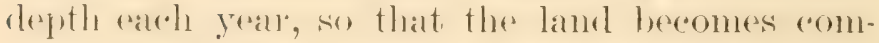
parend meler the furrow. Loose and sandy lands may nemb shallow plowing rather than deep plowing.

9.). (f ) Land which is turned up loose soon dries ont, becalse so much surface is exposed to thes air. In spring, it is often mecessialy to make

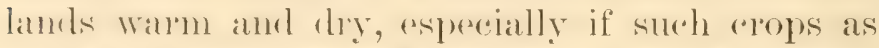
corn and potatoes and rotton are to be planted; and this is done hy very early plowing. The sliesse should not be turned down flat, but allowed to lie up loose and lnoken, and the hamow should not be used until the soil begins to be dry and armully. ('are should be taken not to plow ray lankls when wet, however, else they loreome lumpy and numanageable.

96. (9) Firexzing and thawing often pulverize and improve heavy lancls, particularly ratys. lall plowing, therefore, may be advisable on lamks which teml to remain lumpy. The results are best when the furmow-sliees are left in a perpenclicular position (as in Fig. 21), and when the harrow is not used molil the following spring.

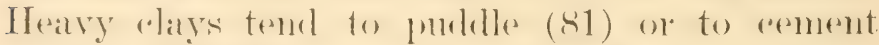
together if fall plowerl, lut the dangere is least when there is herbage (ats heary sod or stubble) or manure on the land before it is plowed. 97. Subsoiling. When it is desired to boosen 
or pulverize the land to a careat depth, the subsoil plow is rme in the furrow behind the ordinary plow. Subsoiling provides a dexper bed for roots, beaks up the hard-pan, and dries the soil. Nore permanent results are nstally obtained by thorough moler-drainage.

\section{3b. B!y surface-worling tools}

9. 'Tillage lig means of surfare-working fools-as hoes, rakes, enltivators, halmows, alod"pushers-has the following objerets: (11) to make a bed in whireh serels ran be som or plants sest, (b) to rovere the serseds, (a) to pulvorize the sromol, (d) to establish and maintain an ealthmuleh, (e) to destroy wereds. Astele from theser spereifice benefits, surfares tillager contributes to the gemeral betterment of soil comblitions, as ontlined in 87, 88, 89 .

99. In making the rarth-muleh (the importanese of which as a savere of moisture is fully explained in sie, sis), the other ol, jects of surfare tillage alre also serourest; therefores we may confine ond attention to the anth-muld for the present. The muleh is made hy shallow tillage-about throe incluss derele, in fiold anditions-before the sereds alle sown. The first tillagere after polowinger is usmally with a heary and

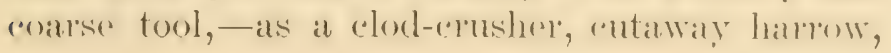


or spring-tooth harrow,-and its object is pulverization of the ground. The finishing is done with a small-toothed and lighter harrow; and this finishing provides the seed-bed and the soilmulch.

100. The earth-mulch is destroyed by rains: the groumel becomes baked. But even in dry times it becomes compact, and capillarity is restored between the mnder-soil and the air. Therefore, the mulch must be maintained or repaired. That is, the harrow or eultivator must be nsed as often as the groumd hecomes hard, particularly after every rain. In dry times, this surface tillage should usually he repeated every ten days, -oftener or less often as the judgment of the farmer may dictate. The drier the time and the country, the greater the necessity for maintaining the soil-mulch; but the mulch is of comparatively little effect in a dry time if the soil moisture was allowed to evaporate earlier in the season.

101. Surface tillage is usually looked upon ouly as a means of killing weeds, but we now see that we should till for tillage's sake, - to make the land more productive. If tillage is frequent and thorough-if the soil-mulch is maintainedweeds cannot obtain a start; and this is the ideal and profitable conclition, to which, howerer, there may be exceptions, 


\section{3c. By compacting tools}

102. The compacting tools are rollers, and the implements known as plankers or floats. The objects of rolling are: (a) to crush clods, (b) to smoothen the ground for the seed-lied, (c) to hasten germination of seeds, $(d)$ to compact and solidify soils which are otherwise too loose and open, $(e)$ to put the land in such condition that other tools can act efficiently, $(f)$ to facilitate the marking-out of land.

103. By compacting the surface soil, the roller re-establishes the capillary connection between the under-soil and the air: that is, it destroys the earth-mulch. In its passage upwards, the soil moisture supplies the seeds with water; and the particles of the soil are in intimate contact with the seeds, and, therefore, with the soil moisture. If the surface of rolled lands is moister than loose-tilled lands, therefore, it is becanse the moisture is passing off into the air and is being lost.

104. The rolling of lands, then, sacrifices soil moisture. The rolled or compacterl surface should not be allowed to remain, but the earthmulch should be quickly restored, to prevent evaporation, particularly in dry weather. Then the object of rolling is to hasten gemmination, howerer, the surfare ramut be tillow at once; 
but if the seed is in rows or hills, as maize or garien vegetables, tillage should begin as soon ąs the plants have appeared.

\section{SUGGESTIONS ON CHAPTER IV}

84a. Tillage is a specific or special word, and is much better than the more general word culfure, when one is spesking of the stirring of the soil. The culture of a erop properly comprises tillage, pruning, fertilizing, and other good care.

$85 a$. For the origin of the word inter-tillage, see foot-note in Roberts" "Fertility of the Land," p. 69.

$88 a$. It should be observed that surface tillage saves moisture by preventing evaporation, not, as commonly supposed, by aasing the soil to absorb moisture from the atmosphere. When moisture is most needed, is the season in which the air is dryer than the soil.

89a. 'Tr illustrate the importance of air, select a thrifty plant, other than aquatic plant, growing in a florist's pot, and excluke all the air hy keeping the soil saturated with water, or even by keeping the hottom of the plant standing deop in water, and note the checkine of growth, and, in time, the decline of the plant. The remarks on draining $(65,78)$ show how undrained soils are often saturated with water; and no matter how much raw material for plant-food may exist in such a soil, it is unavailable to the plant. The reader ean now guess why crops are poor and yellow on flat lands in wet seasons. (In the importance of air in soils, read Chapter ix, of King's "Soil."

89b. On the effects and necessity of tillage, read Chapter iii. in lioherts' "Fertility of the Istud," and chapter xii. in King's "Soil." A most interesting diversion in this commection is a perusil of tethro Tull's famous book on "Horse-Hoeing Husbandry" (53.). Copres of cohbett's alition may frequently bo found in antiquarian book stores.

91a. The trench left by the plow is a furrow. The earth 

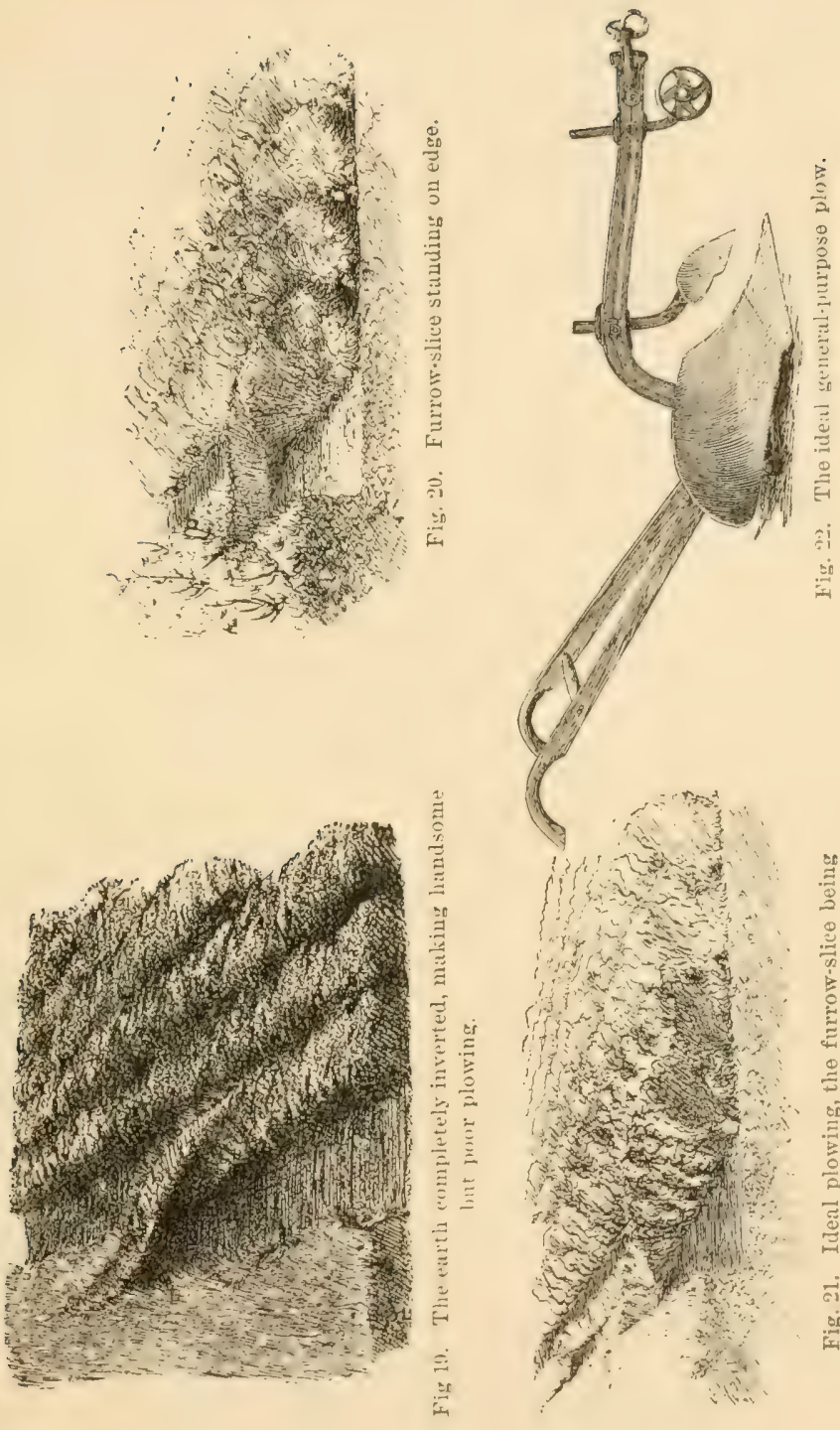

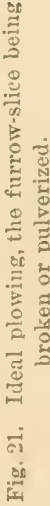


which is turned out of the furrow is a furrow-slice. In eommon. speech, howerer, the word furrow is often nsed for the furrowslice.

916. 'The aceompanying pictures, adapted from Roherts' "Fertility of the Land," illustrate different types of plow-work. Fig. 19 shows the furrow-sliee completely inverted. This kind of plowing looks well, hut it is not desirable unless the object is to bury weeds or a green-crop. The furrow-slices are not broken

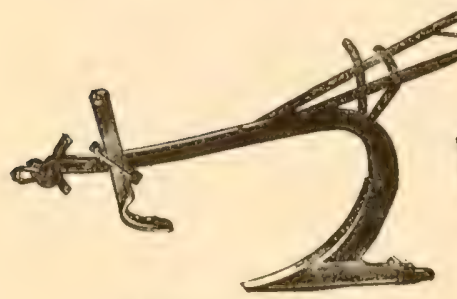

Fig. 23. A subsoil plow.

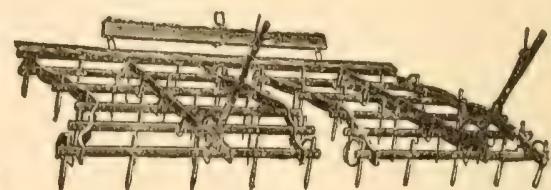

Vig. 24. A smoothing harrow.

and pulverized, and they are in sueh position that the harrow cannot tear them to pieces. Fig. 20 represents work which is better, for most eomditions, although the slices are not pulverized. Fig. 21 shows ideal plowing.

910. 'The ideal plow for general farm work, in Roberts' opinion, is shown in Fig. 22. Observe the "quick" or sharp "arve of the moldhond. For an excellent sketeh of the development of the plow, consult Chapter ii. of Roberts' "Fertility of the Latnd."

$93 a$. About 12 to 20 per cent of moisture in the soil is the ideal eomition for most plants. Let the pupil figure out what the pereentage will be after a rainfall of one inch ox soils that are four inches deep and eight inches deep. Consult Roberts, "Fertility of the Land," pp. 77 to 79.

$94 a$. By hard-pan is meant very hard and more or less impervious subsoil. Some subsoils are lowse; others are so taird as to prevent the downward movement of water and roots $(.9 \alpha)$. 


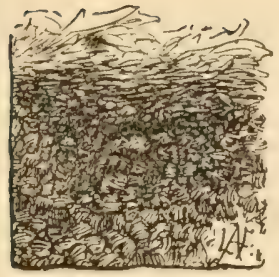

Fig. 25. The loose muleh on forest soils.

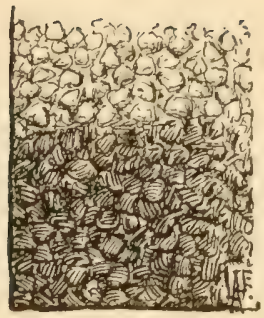

Fig. 26. Tha soil-mulch on tilled lands.

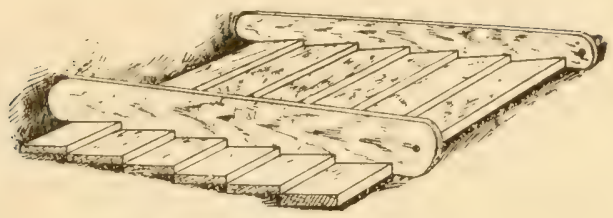

Fig. 27. A home-made planker.

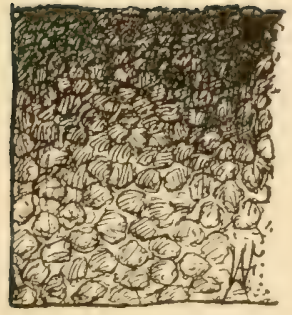

Fig. 28. Showing the effect of the roller in compacting the surface layer.

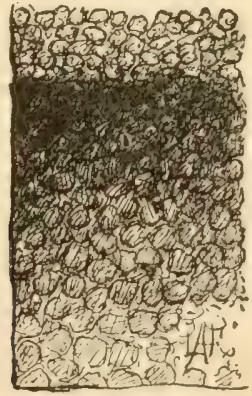

Fig. 29. Showing how the soil-muleh should be re. stored by tillage after the roller has been used. 
97 $\nsim$. The subsoil plow does not turn a furrow (Fig. 23). It is drawn hy an extra team, which follows the ordinary plowing.

99a. A useful tool for making and maintaining the soil-muleh is the smoothing harrow shown in Fig. 24. On hard lands, however, heavier and more vigorous tools must be used.

996. Observo how moist the soil is in forests, even in dry times. This condition is due partly to the forest shade, but frerhaps chiefly to the mulch of leaves on the ground (Fig. 25).

101a. Some farmers are always asking how to kill weeds, as if this were the chief end of farming. But good farmers seldom

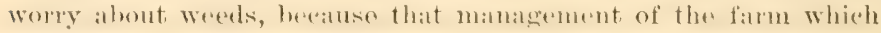
makes land the most productive is also the one which prevents wceds from gaining a foothold. But there are some cases, as wo shall find in the next ehapter, in which weeds may be allowed to grow with profit.

$10^{2} \alpha$. A planker or float is shown in Fig. 27 . 'This is a home-mate device. In some parts of the country it is called a slicker ; and in the West it is known as a drag. In the East, the word drag is synonymous with harrow.

104a. 'T'o determine when and how much to roll land, is one of the most dificult of agricultural operations. 'l'his is because the rood effects are so often followed by the ill effects of loss of moisture and of puddling of hard lands when heavy rains follow. Whenover the object of rolling is to compact loose lands or merely to erush the elods, the work should be quickly followed by the harrow or enltivator. ('ompare Figs. 28 and ag. 


\section{Chapter V}

\section{ENRICIINA THE SOII -FARM RESOLRCES}

\section{What Farm Resources Are}

105. The real fertility of the land is its power to produce crops. It is sometimes said to be the richness of the soil in elements of plant-food; but soils with much plant-food may still be muroductive. Fertility is productive power. It is the result of good physical conclition and an abundance of available plant-food.

106. We have found (in Chapters ii., iii. and iv.) that the first step towarks increasing the probuctiveness of soil is to improve its physical texture. 'This improvement is areomplished both by mechaniend moans, -as tillagge and drainage,-and lig the adelition of humus. The humus results from the application or incolporation of organic matter.

107. We have seen (34) that humus is

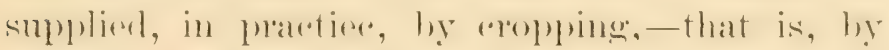
vergetathe matter left on the eremert allere the "rope is removerl, or by apops plowerl moler'; 
and by stable manures and other direct applications.

\section{Cropping Resources}

\section{$2 a$. The kinds of green-manures}

108. The stubbles of grain, elover, grass and sowed corn add considerable hmmus to the soil, and there is also much regetable fiber left in the ground in the roots; and the refuse left from potatoes and warden erops is often important. Sometimes the stubble and roots are nearly as valuable for ameliorating the soil as the part which is removed from the land. This is especially true in clover, partieularly if it is not cut close to the ground. Roberts reports that a second-growth of clover, two yalls from seeding, gave 5,417 pounds per acpe of top and 2, 368 pounds of roots in the unper eight inches of soil ; and the roots usually extend to three or four times that depth.

109. Humus is often secured hy growing ropes for that particular purpose; that is, by the practice of green-manuring. Creen-manure "rops are of thres catexories: (a) recular or full-sason ropse, which oreny the land for one ol more seasons before they are plowed moler, or until they have reached nearly or ynite their full sarowth; (b) ateh-erops, which are arown in the seasons between other arops; 
(c) cover-crops, which are sown late in the season for the purpose of protecting the soil druing winter as well as for green-manming.

110. Green-manuring crops may be again divided into those which gather nitrogen and those which do not,-or those which have the power of using the nitrogen (see Chapter vi.) of the air, and those which ohtain all their nitrogen directly from the soil. The nitrogengatherers leave their nitrogen in the soil, when they decay, for the use of other plants. The nitrogen-gatherers are the leguminous plants, or these which belong to the pea family, as all kinds of peas and beans, clovers, alfalfa, veteh. 'The other class, or nitrogen-consumers, comprises all other plants used for green-manuring, as rye, oats, raje, mustalel, buckwheat, maize.

111. In general, the best green-manure crops are the legumes,-red clover for the North, alfalta for dry regions, cow-peas and Japan clover for the South. With the exception of the cow-peas, these crops reguirs one or more seasons for full development, and, therefore; cannot be used in intensive faming.

\section{2b. The management of green-mamures}

112. The irleal green-manming is that which is a part of a regular rotation,-the green- 
mamme copl, or the stubble or sod, occurring regularly chres "vely few years, in alternation with whrat, potatoes and other staple crops. 'This, howerer, is possible only with general or mixarl hushandry (ta). In market-gardening, and other intensive farming, catch-rops are often userl. In fruit-growing, cover-colops are frequently used.

11:). But even in intensive farming, the land sometimes heromes mupoductive from too contimuous roppling with ons thing, and the too persistent use of one kind of fortilizer. It is then often "resterl" hy sereding it to clover"; but the goon effrets alle not the result of a rest, but of rotation or change of crop.

114. It is neopssary to distingruish between the reffects of eneren-crops in improving soil texture and their afferets in enriching the soil; for soils which may need improving in texture may not nosel emriohing. In fruit-growing this is often trus; and the heavy arldition of nitrogeten (which comdures to ereowth of wood) may (atuses the plants to gerow too heavily and to bear little, ame to low too susceptible to dis(atse and to rold. In such rases, the nitrogencomsumers are the better ropose. One must be (alreful not to indures an over-growth in srapes, peaches, apricots, and pears.

115. On liard and poor lands, it is often 
difficult to sereure a "catch" of "lover. In such cases, it is wrll to begin with fall-sown rye or field peas. When the soil has become nellow, clover may be successful.

116. Cover-rops are nsed mostly in fruit plantations. They are sown in mirlsummer, or' later, after tillage is completed,--for tillage should cease early, in order that the fruit plants will not grow too heavily and too late. The cover is plowed under early the following spring ( 7 t 1 ). The cover checks the growth of the fruit plants, prevents the land from washing and purdling, holds the rainfall until it can soak into the soil, causes the soil to dry out early in spring, lessens injury from frost.

117. Weeds often make gool rover-crops. The "hiet difficulty is that they rammot be relied upon to appear when and where and in the cuantity wanted, and some kinds may be difficult to eradicate (101a).

\section{Direct Applications}

3a. Stable manures

118. The best direct application which the farmer can make to his land, from his home resomres, is stable manmre. It supplies both humus and plant-food. 
119. The value of manure depends upon (a) the kind of animal from which it is made, (b) the feed which the animal receives, (c) the amount of bedding or litter which it contains, $(d)$ the way in which it is kept $\mathrm{Or}^{\circ}$ housed.

120. Some of the most valuable constituents of manure are soluble, and are, therefore, removed by water. (onserpuently, manures should be housed to protect them from rain. A covered barn-yard is the ideal place in which to keep manures, for they are not only protected from weather, but, if the manuro contains enough straw or litter, it makes an agreeable bed upon which stock may tramp, and it absorbs the liquids; and if it is spread in the yard as it is marle and well tramped by stock, its tendency to heat is reduced. In six months' exposure to weather', mannres usually lose more than half of their arailable plant-food.

121. The more completely rotted the manure, the sooner does it hecome thoroughly incorporated with the soil; and the decay of the coarse parts renders their plant-fool more available. If the rotting proceeds under cover or in a compost pile (3tu, Fig. 5), there should be little loss of plant-foor by leaching.

122. If manure cannot be sheltered, it should be spread on the fields as fast as 
niade. There is practically no loss of plantfood from evaporation, and the part which leaches is caught hy the soil. Loose or strawy manure which lies too long on the ground, however, may become so dry that it does not ynickly decay when plowed under; if applied very thick, it prevents heary soils from drying out, and thereby delays spring work.

\section{Other dressings}

123. Nuck is often useful as a somrce of humus, but it generally contains little directly available plant-food. It is generally improved if dug and allowed to weather some time before it is put on the lami. Dry muck is rery useful in stables and covered harn-yards to alssorth the liquids; and its value as a dressing for the land is thereby increased.

124. Peat, when decomposerl and soil-like, becomes murk. Peat, therefore, is less valuables than muck as a dressing mutil it has been thoroughly broken up and decomposed by weathering or composting.

125. Marl is usually not rich in available plant-food, but, like muck, it may be valuable to improve the physical condition of the soil. But only in exceptional cases is it worth hauling great distances.

126. Such materials as sawdust, straw, 
leaves, pomace, are gronelally moles valuable for the improving of the texture of the soil than for the direct arldition of plant-food. If the soil is loose, dry and leachy, or if it is very hame, comparet and retentive, these maferials may benefit it. To determine the value of such materials in plant-food, one must consult tables of theil composition in books; and the more thoromghly they are rotterl, the more available are their constituents.

\section{SUGGESTIONS ON CHAPTER V}

108a. "The proportion of roots to tops [in elovers] varies widely. The medium red clover, one year from seeding, gives a much larger proportion of roots to tops than clover two years from seeding. Red clover which produces two tons per acre may be expected to furnish potentially to the soil, after the first eutting, in roots and stubble, 40 to 60 pounds of nitrogen, 20 to 25 pounds of phosphorie acid, and 30 to 50 pounds of potash. Thirty bushels of wheat * * * and 2,700 pounds of straw, would remove approximately 46 pounds of nitrogen, 20 pounds of phosphorie acid, and 26 pounds of potash."Roberts, "Fertility of the Land," 845.

109a. Accessible discussions of green-manuring are to be found in Chap. xiv., "Fertility of the Land;" pp. 117-123, Voornees" "Fertilizers." Cover-erops in relation to fruit-culture are diseussed in pp. 184-202 of Bailey's "Principles of Fruit-Growing," and in other books and recent bulletins.

111a. Intensive farming is "high-eulture" farming. It is farming on a comparatively small seale, when the land is kept constantly in productive erop, with the best of tillage, and the heo use of manures and fertilizers. The land is forced to its 


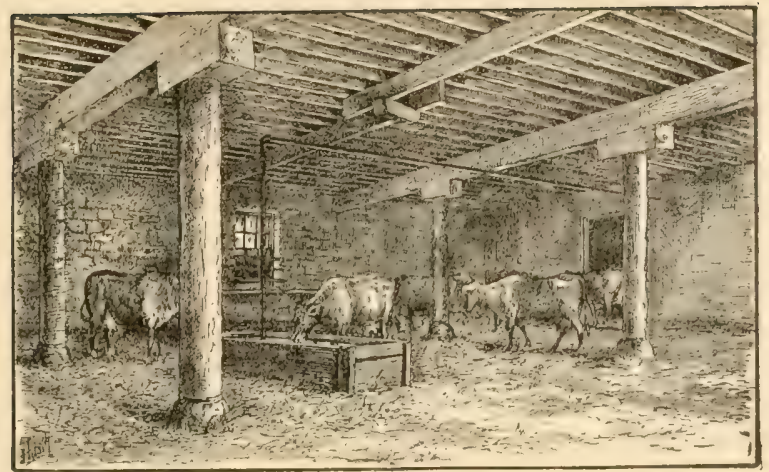

Fig. 30. A covered barn-yard, in which manure is saved and the stock protected.

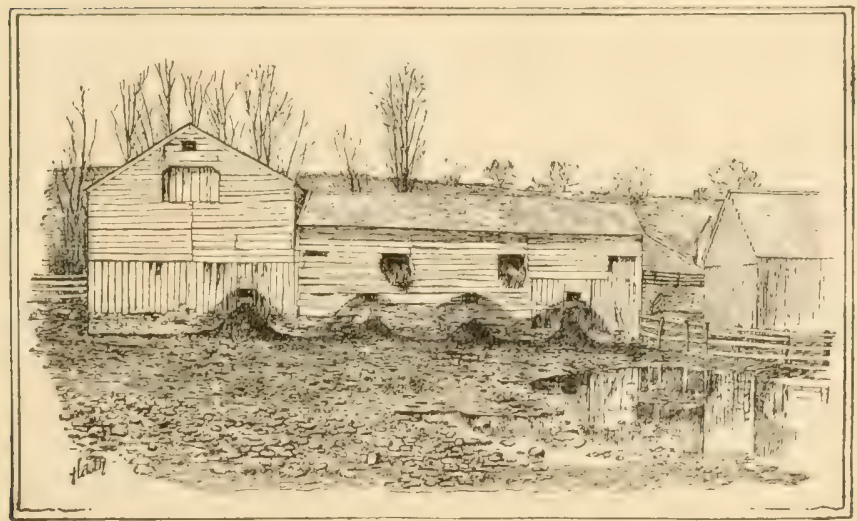

Fig. 31. A common type of barn-yard. The stains on the barn show where the manure was baptized from the eaves; and the mud-puddle showa where much of the fertility has gone. 
utmost capacity. Darket-erardening and forcing-house eulture are examples.

111b. Extensive farming is general husbandry, especially when done on a large scale and without forceful methods of tillage and ropping. Grain-farming and stock-raising are $e^{\mathrm{X}-}$ amples.

120a. A covered barn-yard is shown in Fig. 30. This is a basement under the farm barn at Cornell University. This affords a protected place in which the stock may exereise in cold weather; and if the cattle are dehorned, they remain to-

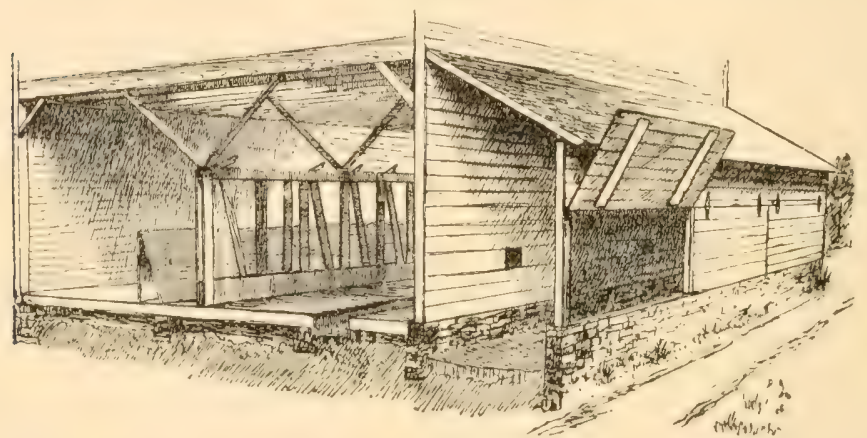

Fig. 32. A handy and economical stable, with cattle-racks, a manure trough (behind which is a walk), and a small shed at the rear, with a hollowed cement bottom, for the storage of the manure.

gether peaceably. Such an area not only saves the mamure, but it adds to the welfare and value of the stock. Compare this with the commoner type of yard, as shown in Fig. 31. A hamely aml effeient arrangement for the saving of manure is shown in Fig. 32. For general discussions on farm manures and methods of saring and hamdling them, consult Roberts, "Fertility of the Land," Chapters vi., vii., viii., ix.

126a. Muck, marl, and other materials of this class are "onsidered in Vonrhees" "Fertilizers," ('hapter vi.., and in Roberts" "Fertility, Chapter xiii." snd the appendix to the latter work has full tables of the fertilizer constituents of very many substances. 


\title{
Chapter VI
}

\section{ENRICHING THE SOIL-COMMERCLAL RESOURCES}

\author{
G. W. OAVANAUGH
}

\section{The Elements in the Soil}

127. Chemically, a fertile soil is one containing an abundance of available plant-foorl. The substances which are necessary for the growth and welfare of plants are called plantfoods. There are about ten essential elements of plant-food. Six of these are derived from the mineral part of the soil,-phosphorus sulfur, irou, calcium, magnesium and potassium. Nitrogen is contained in the humus. Water supplies the hydrogen and oxygen to the roots. Carbon comes from the air. Fortunately, the greater part of the plant-food elements of the soil always exist in quantities more than sufficient to supply any possible need of the plants.

128. Three of these elements ame often deficient in the soil; or, if present, thoy may not 
be in condition to be used by the plant. These are nitrogen, phosphorus, and potassimm. A fourth plant-food is also sometimes defieient,ralcium. These four substanes, therefore, are the ones which the farmer needs to eonsider when fertulizing the land.

129. Bofore the plant "an use any of these elements of plant-foml in the soil, they must become dissolved in the soil water, which is absorbed by roots.

130. While all plants need certain elements for their wowth, they rammot use the elements in their alemental or uneombined forms. In fact, the elements as such do not exist in the soil. They are united with each other in compounds, and it is by absorbing the compounds that the plants obtain the necessary elements. Phosphorus is essential to the life of plants, but it is never used by them in the form of elemental phosphorus. It is always in some compouml, as phosphorie acid or a phosphate.

1:31. When the compounds exist in such condition as to be readily absorbed by the roots, the soil is sairl to contain available plant-food. Often there is sufficient plant-food present, but not in andition to be taken up; by the plants. It is them sairl to be mavailable, or to be locked up. Availability is restermined by two faetors: by the substane being 
soluble in soil water; by its being sf such connposition that the plant will use it.

132. One problem for the arronturist is to secure available plant-foorl, and to determine whether it is better to molock the plant-food in the soil hy means of tillage, or to supply the elements in some manure or fertilizerle

1:3.). Barn manums ape not always to be harl, and they are varial, le in romposition. It is often adrisable, therefore, to substitute ammereial of" concentrater fertilizers, in which the ennstituents are of known amounts and often rearlily arailable. Barn manures are bulky. Even manure of cattle from a rovered yard contains as high as 70 or 75 ) per cent of water, and 11 sually less than 1 per cent of nitrogen, phosphoric acid or potash. If it were not for its influence in improving the physical effects of the soil, stable manure would have comparatively little value.

\section{Nitrogen}

134. Nitrogen is the most important element which the farmer adds to his soil. It comprises part of all green and woody parts of plants. It seems to lee the element most intimately associaterl with rapid growth in plants. I'lants that feed exressively on nitrogen tend to mo- 
duere latren leatres and stallis, while the hardi-

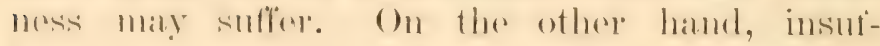
fiovent nitrogen is almost ooptain to result in dwarding and loss of vitality. It must pereive altention, also, beranse one form, the nitrate, tends to leach from the soil.

135. In a pure or elemental state, nitrogen is an invisible ats. It romprises fomr-liflls of the atmosphere. And yot, with this vast amoment about 11, , it is the most axpensive alement of plant-ford. The nitrogen of the air ain not be used by the ereat majority of plants, because it is in what is known as a free or mrombined state. 'The someres of nitrogen for plants are ammonia, nitrates, or in some ampround formed by animals or plants (that is, in some organic form).

1:30. If the gats nitrogen ise ambines with the gas hydrogen, there will be formed ammonia ( $\left.\mathrm{N} \mathrm{H}_{3}\right)$. From this the plants am derive, inclirestly, their supply of nitrogen.

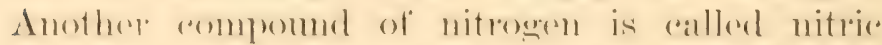
acold, whish is composent of nitrogen, hydrogen, and oxyen $\left(11 \times()_{3}\right)$. When seme mineral comente takes the platere of the hydrogen in this ammbination, the ammommel is ablled at nitrate: as Nil $\times()_{3}$, nitrate of sodal; KN( $)_{3}$, nitrate of potish, of saltperter. Both ammonia and nitrates ane formel in. thes soil in small 
quantities, but only in a fertile soil in sufficient amounts to supply the plant with nitrogen.

137. Humus is the great storehouse of nitrogen. Humus does not dissolve in water, and so serves as a means of retaining the nitrogen against learhing. But if the nitrogen remaines always in the humus, it would not be availahle to plants, sinee to be absomber it must dissolve in the soil-water. Fortumately there is a process wherely the nitrogen in the insoluble humus is marle to be avalable. This process is the work of germs or mirro-organisms (:35, 3.5). These germs are of sereral kinds. ()ne kind works upon the humus and changess its nitrogen into ammonia, and other kincls rehanges the ammonia into, nitrice acisl. This process of changing nitrogen into the form of nitrice ar.iel or nitrate is callerd nitrification. It is probable that nitrogen muters the want chiefly in forme of nitrate, so that all other forms of nitrogen must undergo nitrification, on be nitrified, before they are of use. Since tillage pronotes the activitios of the microorganisms (3.5, 5.2, 89), it thereby increases the supply of available nitrogen.

138. It has been stated (195) that the great quantity of nitrogen in the atmosphere is not available to most plants, berause it is not in a combinerl state. Thern are certain plants, 
however, which hare the power of drawing upon this supply for their nitrogen. They are

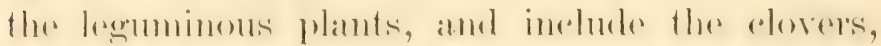
pas and heams (110). These plants have knols or nodules erowing nom their roots. These molules atre the homes of eremer and these

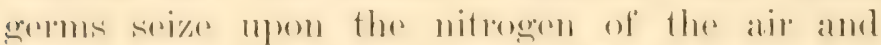
turn it over to tho plant. This process is known as the fixation of nitrogen. Then if

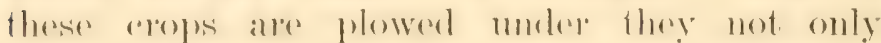
athl humber from their vegerable substance, lute nitrogen which has beren gatherest from the air.

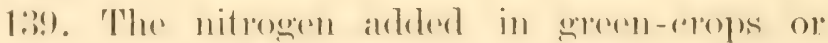
hommes must an through the process of nitrifieation before it is arabiable to the plant. sometimes this pooess does not fumish nitrie

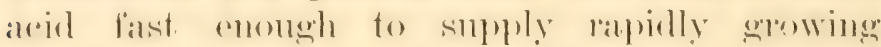
plants, and then a form of available nitogen

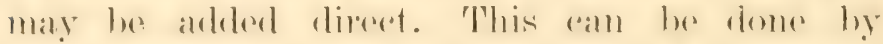
using nitrate of sola or sulfate of anmmonia. The former is mined in thite; the latter is a substanere obtained from gas works. The antmonial formed from the nitrogen that was in the

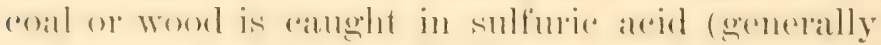
known as oil of vitriol). Therse fwo substances, tenesther with dried blomel from the slanghter homser, entistute the hest commereial sourees of nitrogen. 


\section{Phosphoric Acid}

140). Phosphorie ared is, next to nitrogen, the most important plant-fores to bes applied to lamel, and of the minerel aomstituments it is the most important. It is a constiturent of all soils, thongh the amomint math be variable. It is palltirolarly nexpled to insure hardiness and fruitfulness. Conserquently the different grain erops are larger users of phosphorice acoil. $A$ liberal supply of arailable phosphoric aced is necessary to yome blants to give them strength and vigor.

141. As humms decays or decomposes in the soil it not only supplies nitrogen, lut it also makes somer of the phosphorie areid available. Henees when the humus diminishes in the soil, these is often a correspomeling lacek of atvailables phesphorire aroirl. Barm mammes make available a considerable quantity of phosphorige acode Sorls which rontain a fatip supply of humus do not neressialily have momere of phosphorie areid.

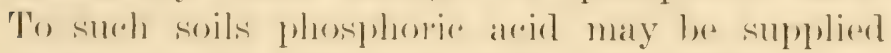
in an available form in arod phosphates.

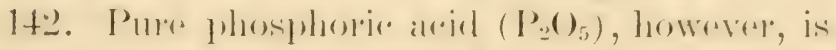
mot nsed direstly as a plant-food, but only when it is aombinesl with some ofluer substances, as lime. (One of the rhief somerese of phosphorio: acid is bone, in which it is found combined 
with lime. The animals obtained the phosphoric acid from the plants they ate, which in their turn sereneel it from the soil. Anothere creat somere are the deposits of phosphatio rooks in the carolinas, Floridal and Temessiese. In these rocks the phosphoric areid and lime alle combined in the same way as in bones.

14.?. Bones and phosphorice rorks do not dissolve in water, amb anserpently the phosphoric acold they contain is not easily alsorthed hy roots. These materials, therefore, ale rommonly treated with areid, to make the phosphoric aciel soluble; and the material is then known as an acid phosphate.

14t. In homes, one part of phosphorice aceis $\left(\mathrm{P}_{2}\left(\mathrm{O}_{5}\right)\right.$ is rombined with threes parts of limes (Cal) a amb am he expressied als follows:

$$
\left.\left.\begin{array}{ll}
\text { Lime } \\
\text { Lime } \\
\text { Lime }
\end{array}\right\} \text { Phosphoric aced; or, } \begin{array}{ll}
\mathrm{CaO} \\
\mathrm{CaO}
\end{array}\right\} \mathrm{P}_{2} \mathrm{O}_{5}
$$

This substance is tri- (of threes) calcede phosphate, and is insoluble. When sulturle aceld (ol' oil of vitriol) and water are inronght in rontact with the bones, part of the lime leares the phosphorie acid, ame its platere is taken by water. If one part of the lime is united with the sulfuride arold, then there results a substance which can be written thus: 


$$
\left.\left.\begin{array}{l}
\text { Water } \\
\text { Lime }
\end{array}\right\} \text { Phosphorie acrd; or } \begin{array}{r}
\mathrm{H}_{2} \mathrm{O} \\
\mathrm{CaO}
\end{array}\right\} \mathrm{P}_{2} \mathrm{O}_{5}
$$

This is di- (or two) calcic phosphate. This is insoluble in rain-water, but beeomes soluble in the soil-water.

145). If two parts of the lime les mited with sulfuric acid and their vlaces be taken by water, there remains :

$$
\left.\left.\begin{array}{l}
\text { Water } \\
\text { Water } \\
\text { Lime }
\end{array}\right\} \text { Phosphorie acid; or, } \begin{array}{r}
\mathrm{H}_{2} \mathrm{O} \\
\mathrm{H}_{2} \mathrm{O} \\
\mathrm{CaO}
\end{array}\right\} \mathrm{P}_{2} \mathrm{O}_{5}
$$

This is mono- (or one) calcic phosphate. Tinis is readily soluble in soil water, but in the soil it tends to become insoluble, ol to levert to the dicalcic form (and is the'n said to he "reverted"), and some of it may eventually berome tricalcic. and matrailable. The lime that is removel hy the sulfurice aroid mites with thes sulfuric aroid to form calcium sulfate; that is, plastel (1) y ysum

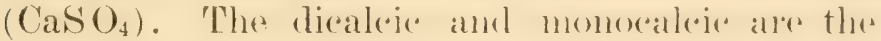
forms that are known as ateil phospluate, and sold in commercial fertiizers.

\section{Potash (potassium oxirle, $\mathrm{K}_{2} \mathrm{O}$ )}

146. Next to phosphoric arid, potash is the most important mineral plant-food. It is phareerl after phosphoric acid in importance not be- 
mallser plants and better do without it, hut beramser it is menally meres abmolant in soils. Potash has an important office in the production of time, woonly tissue and of stareh, and it is thomeht to be particularly neseded by truitplants, potatoese, and poot rops. It is gemarally defiroment in simely and praty soils.

147. Like phosphorice aleid, potash beromes availathe with a liberal supply of humus and hy erood tillager and the potash in barn manures is soluble and valuable. Thernever wood alshes ram be ohealply ohtaimed they form a valuable sompere of potash, for the potash taken from the soil by the treses remains in the ashes when the wood is bumed.

14s. Potash is fomme in great deposits in Gemlany, very much as common salt is fomel in the Enited states. Theres it is mined and solel. It aen les bonght in the form known as the muliate of jotash, or mone properly potassimm rhlorid, Ke'l. Another forme of potash is

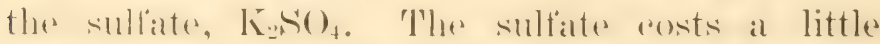
more than the othere, herallse it is matle from the muriate. For enemeral purposes, the muriate is renommendend orer the sulfate hecause it is chalpere; but thre muriate has a deleterious afferet (m) tobarero, and it is thought to give less satisfiatory lesults on sugar-cante and potatoes. 


\section{Amendments}

149. Substances which eontain only traces of the important or available plant-foods often have a beneficial efferet on soil. Lime and salt are examples. Thomen they may not add to the soil any nexderl plant-food, the plants are enabled hy their presences to utilize more of the plant-food alrearly in the soil. Wuch materials are known as amendments (58).

15). It is often difficult to decide, in any particular case, just how an amendment produces its effect. It may be that the mechanical condition of the soil is improved, its waterholding alpacity inereased, its acidity or sourness neutralized, or its plant-food unlocked.

151. Lime. Soils sometimes bereme sour. and may then be unsuitable for some plants. One of the rasens why plants an not thrive well in some soils is that it is difficult to obtain suffeient nitrogen in the form of nitratrs. The ererms which carry on the process of nitrification are mable to do their work in sour soils. The soil acid can bo neutralized - the soil sweretened - by applying lime (which is alcium oxide, (aO) .

152. Lime maty be applied in the form of water-slaked lime, such as is obtained by adding water to quick-lime till it crumbles, or by airslaked lime. Quick-lime usually gives the better. 
results, particularly when it is desired to improve the texture of clay soils $(58,58 a)$.

153. A soil may be tested to determine if it is ardid by placing a piece of blue litmus paper (kept at drug stores) against the moist soil. If the palper reddens and remains so after drying, it shows the presence of an aleid in the soil. It is best to apply the paper not to the top of the soil, but to the side of a hole such as would be made hy inserting a spade and moving it to and fro.

\section{Commercial Fertilizers}

\section{6a. What they are}

154. Inter the name of eommereial fertilizers, one can buy the various forms of nitrogen, phosphorie aldid and potash. These elements may be purchased singly or mixal in any ambination. A fertilizer containing all three is a alled a compete manme or fortilizer. In huying, one should

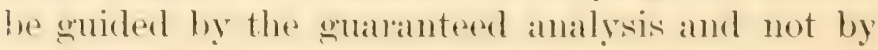
any particular name or brand.

1.5.). The commeredial vilue of nitrogen is about three times that of either phosphoric acid or potash, which ale approximately 5 cents per pomml. The prices of these elements may valy, lut the following wild serve as an illustration of the computing of relative values of different fer- 
tilizers (remembering that 1 per cent means one pound in a hundred, or twenty pounds in a ton):

\section{No. 1. Guarantefe Anatusis}

Nitrogen . . . . . 1.60 to 2.00 per cent

Phosphoric acid available .7 .00 to 8.00 " "

Potash . . . . . . . 2.00 to 3.50 ". "

Cost per ton, $\$ 29$.

Multiplying the lowest figure representing the per" cent of the given element by 20, and calculating the value from the price per pound, we have in No. 1:

Nitrogen . . 1.60 X20=32lbs.@15e. $=\$ 480$

Phosphoric acid $7 \times 20=140 \mathrm{lbs}(0 \mathrm{c}=700$

Potash . . $2 \times 20=40 \mathrm{lbs} .(a)=\frac{50}{2}=200$
Commereial value per ton . . . $\$ 1380$

156. Another example of computation may be taken:

\section{No. 2. Guarantefid Analysis}

Nitrogen . . . . 3.30 to 4.00 per cent

Phosphorie acid available . 8.00 to 10.00 " " "

Potash . . . . . . 7.00 to 8.00 " "

Cost per ton, $\$ 38$.

Its value is calculated the same as No. 1:

Nitrogen . .33 $30 \times 20=66$ lbs.@15e. $=\$ 990$

Phosphoric acid $8.00 \times 20=160 \mathrm{lbs}$ (@) $5 e=800$

Potash . . $7.00 \times 20=140 \mathrm{lbs}$ (16) $5 \mathrm{c} .=700$.

Commercial value..... $\$ 2490$ 
100 THE PRINCIPLES UF' AGRICULTURA

157. The cheapest fertilizer is the one in which one dollar purchases the greatest amount of plant-food. In No. 1, \$29 olotained \$13.80 worth, which is at the rate of 48 cents worth for $\$ 1$. In No. 2, $\$ 38$ buys $\$ 24.90$ worth of plant-food, or at the rate of 65 cents worth for the dollar. The difference between the commer.cial value, as calculated, and the selling price, is to cover expenses of manufacture, wagging, shipping, commission fees, and profits.

\section{Advice as to their use}

158. We have seen that plants must have all three of the general fertility elements-nitrogen, phosphoric acid, potash-in orker to thrive. It freculuently oceurs, however, that the soil is rich enough in one or two of them; and in that case, it is not necessary to apply all of them.

15.). If a liberal anplication is made of one element, the plant must use more of the other elements which are already in the soil, in order to balance up its growth. It may result, therefore, that the addition of one element exhansts the soil of some other eleusent. For example, if heavy growth is olstained by the addition of nitrogen, the plant may need to draw so heavily upon the stores of available phosphoric acid as to deplete the soil of that material. 
160. Again, no results can be obtained from the addition of one element unless the other two are present in sufficient quantity. In general, therefore, it is safer to apply complete fertilizers.

161. Yet, in some cases, it is nnwise to apply complete fertilizers. This is particularly true of the application of nitrogen. The growth may already be so heavy that the addition of nitrogen would cause an overgrowth, and yet the plants may need fertilizing. 'This danger' of too much growth is greatest with fruit plants (114).

162. If nitrogen conduces especially to leaf growth (134), then it must be the element which is most important in the fertilizing of the regetables which are grown for their leaves or succulent stalks, as rhubarb, cabbage, lettuce, spinach, asparagus; and it is also very important in the growing of hay and succulent fodder.

163. Nitrogen leaches rapidly, especially if applied in the form of nitrate of soda or sulfate of ammonia. It is, therefore, advisable to apply it in the spring; and when used in liberal amounts, it should be applied at intervals, and not all at one time.

16it. Phosphoric acid and potash, even if soluble, do not leach badly, as a sule, hecanse 
they tend to form insoluble compounds with soil comstituents. The more vegetable matter a soil contains, the less pronomesed is the action of leaching. As a rule, commereial fertilizess are alpolion after the ground is fitter, and then harrowed in or drilled in.

16.). 'The amomnts and kinds to apply are detemines by (11) the analysis of the material (that is, its richuness in plant-food), (b) its rost, (r) the riohness of the soil in plant-food, (d) the tilth or texture of the soil (60), 49a), (e) the kind of 'olop', $(f)$ the kind of farming, whether intensive or extensive $(111 a, 111 b)$. It follows, therefore, that the mere analysis of the seil and the plant ammot determine what fertilizer it is most profitable to use.

166. What fertilizers to use, and how to apply them, are subjects which are discussed in bullotins and books by many authors; but even alfer reading all the literature, the farmer must experiment with his own land and his own erops, to determine just what materials are most profitable for his nse. In other worts, the advioe as to fertilizers is mope valuable in teaching a man frineiples, in sugeresting means of experimenting, and in designating the probabilities of any line of action, than in specifying just what fertilizers one shall use. An area on one siclo of a field may be devoted to such 
experiment, on rifferent parts of which the valious elements and combinations of them may be applied.

\section{SUGGESTIONS ON CHAPTER VI}

127a. An element is a simple substance. It is not made by a combination of any other substances, and by no known means can it he separated into any other substances. Sulfur, nitrogen, and phosphorus are elements. 'The known elements number about 70 .

127b. T'he elements are represented by one or more letters, called symbols. Tsually the first letter of the name is employerl. Thus, nitrogen is designated by N, phosphorus by $\mathrm{P}$, sulfur hy s. When the names of different elements begin with the same letter, as sulfur and sodium, this rule eannot be followed. In such cases, letters from the name of one of the elements in some other language are used. 'Thus, $\mathrm{Na}$ is used for sodium, natrium heing the Latin of solium. Similarly, P might represent phosphorus or potassium ; hence $K$ is used for potassium, which in Latin is kalium.

130r. Compoundis result from the chemical union $(30 c)$ of two or more elements. The compound may not resemble in any way any of the elements containel in it. The proportions in which elements unite vary, and the sime elements may he made to unite in different proportions. The same compound always enntains the elements in exactly the same proportion.

130b. Compounds are represented by writing together the symhols of the elements composing them, together with figures 10 represent the proportions. Thus, potash, $\mathrm{K}_{2} \mathrm{O}$, is a compound of two parts of potassium and one of oxygen, O. Lime, CaO, is composed of the elements calcium, Ca, and oxygen, and its (hemical name is ealcium oxid. ()ther compounds are nitrate of soda, $\mathrm{NaNO}_{3}$; ammonia, $\mathrm{NH}_{3}$ (II representing the element hydrogen); water, $\mathrm{H}_{2} \mathrm{O}$; sulfuric aceid, $\mathrm{H}_{2} \mathrm{SO}_{4}$; ammonium nitrate, $\mathrm{NH}_{4} \mathrm{NO}_{3}$; ammonium sulfite $\left.\left(\mathrm{NII}_{4}\right)_{2} \mathrm{so}\right)_{4}$ (the $\mathrm{NH}_{4}$ leeing talien twice); stareh, ( ${ }_{61} \mathrm{H}_{11}()_{;}$( ('; representing carbon); salt, Na('l (Cl standing for chlorin). 
130c. Phosphoric aeid and potash are not elements, but compounds. The elemental forms are phosphorus and potassinm. It is customary, however, to speak of nitrogen, phosphoric acid and potash as the elements of plant-food. Here the word element is not used in the chemical sense, but rather as the simplest form in which plants can use these substances.

131a. Roots have the power of dissolving plant-food (30, $30 a$ ), but this is only a process of making it soluble. Substances which are not soluble in rain water may he soluble in soil water, for the water in the soil contains various acids. Even when a substance is in solution, the plant has the power of rejecting it ; it is thereby not available as plant-food. For example, nitrogen

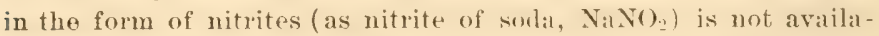
ble, although it is soluble; but nitrogen in the form of nitrates (as nitrate of soda, $\mathrm{NaNO}_{3}$ ) is availalle. ('hareoal is not available plant-food, although it is earbon, and earbon enters more largely than any other element into plant tissue. But when the charcoal is burned, it forms a gas called earbon dioxid or earbonic acid $\left(\mathrm{CO}_{2}\right)$, from which the plant ean get earbon.

$140 \alpha$. The black or blue head of an old-fashioned sulfur match is a paste containing the element phosphorus, P. On igniting the match, this phosphorus unites with the element oxygen, $O$, in the air to form a small white eloud, which is the compound phosphorus pentoxid. Its symbol is $\mathrm{P}_{2}\left(\mathrm{O}_{5}\right.$, which means that it is made by the union of two parts of phosphorus and five parts of oxygen. Phosphorus pentoxid is known in agriculture as phosphoric acid.

143a. The term superphosphate is sometimes used in the same serse as acid phosphate; that is, to designate avalable phosphates, or those which are made up of monocalcic and dicalcic phosphates. A fertilizer containing available phosphoric acid, but no nitrogen or potash, is often called a plain superphosphate. Complete fertilizers contain all three of the important plant-foods.

153a. Moisten a strip of blue litmus paper with vinegar or sour milk, and note the change in color. Then add to the milk or vinegar some lime water till it no longer tastes sour, and 
again try the litmus paper. It will no longer turn red. 'Try some air-slaked lime in the same way. Make the same test with plaster of paris or sypsum, which is sulfate of lime. This will not neutralize the acid or sweeten the milk or vinegar. Make the same test with salt and sugar. A substance which turns blue litmus red is acid; one which turns red litmus blue is alkaline.

$166 a$. The experiment stations of most of the older states issue bulletins of advice on the use of fertilizers, and these should bes studied. In many states there are laws designed to protect the purchaser of fertilizers; and fertilizer control stations are established to analyze the different brands and to puhlish the results. The general subject of fertilizers is presented in Voorhees' book on "Fertilizers." Good advice will also be found in Chapter xii. of Roberts' "Fertility."

166b. Every school should have bottles of the leading fertilizer chemicals for exhihition ; ats muriate and sulfate of potash, kainit, gypsum or plaster, bone and rock phosphates, boneblack, dried blood, nitrate of soda, sulfate of ammonia, airslakel lime, aml quick-lime. These can be obtained from dealers in fertilizers. 


\section{PART II}

\section{THE PLANT, AND CROPS}

\section{Chapter VII \\ THE OFFICES OF THE PLANT \\ 1. The Plant and the Crop}

16i7. In an agricultural sense, the plant, as a representative of the vegetable kinglom, has fint general types of uses, or fulfils four offices: it airls in the formation, maintenance and improvement of soils; it influences the climate and habitalileness of the earth; it is the ultimate somres of food of domestic animals; it, or its products, may be of intrinsic value to man. 168. When plants are grown in quantity, they, or their products, constitute a crop. This "rop may be the produce of a beuch of carnations, a field of harley, an orehard of peaches, a plantation of tomatoes, or a forest. The crop may be grown for its own or intrinsic value, or for its use in preparing the land for other crops. 


\section{The Plant in its Relation to Soil}

169. The plant is a soil maker. It breaks down the rock by mechanical force and by dissolving some of its constituents $(30,30 b)$. It fills logs and lagoons and extends the margins of lakes and seas $(32,32 \imath)$.

170. The plant is a soil improver. It opens and loosens hard soils, espercially if, like the elover, it has a tap-loot, which it sends deep into the earth. It fills and linds loose and leachy soils. When it deeays it adds humus $(33,34,73,74)$.

171. 'The plant is a soil protector'. It prevents the washing of soils, and proterts the sands of dlunes and shores from the winds. It holks the rainfall until it soaks into the soil $(70,116)$.

\section{The Plant in its Relation to Climate}

172. The plant influences the moisture supply: by modifying the distribution of precipitation; by causing the retention of the precipitation; by lessening evaporation; hy adding moisture to the atmosphere.

173. The plant influences the habitableness of the earth by other means: as by modifying extremes of temperature; ly afforling wind- 
breaks; by suplylying sharle; hy contributing to the beanty and variety of the landscape.

\section{The I'lant in its Relation to Animal Life}

174. Nearly all domestic anmals live directly on plants. These are herbivorous animals, such as cattle, horses, sheep. But even the Hesh which carnivorous animals pat-as dogs, eatsis directly or indirectly deriver from herbivorous animals ; for "all flesh is grass."

175. The round of life berins and ends with the soil. The soil contributes to feerling the plant, the plant feeds the animal, and the animal passes at last into the soil. In this round, there is no creation of plements, and no loss; but there are endless combinations, and these combinations break up and pass array. To raise the plant, therefore, is the primary effort in agriculture.

\section{The Plant has Intrinsir I'alue to Man}

5a. As articles of food or beverage

176. Plants or plant-products may be staples or necessaries, as wheat, rice, potatoes, heans; semi-staples, or articles of very general and rommon use, as apples, oranges, buckwheat; 
luxuries or accessonies, as quinces, eanliflowers, glass-house vegetahles; condiments, as spices; beverage products, as cider, wine.

17\%. Plants or plant-products may be food for animals, as grains, ground feed, fodders, forage or field pasturage.

5b. As articles used in the arts

17R. Plants may afford textiles or fibers, as cotton, hemp, flax, jute; wool, lumber and timber ; medicines, as quinine, opium, ginger.

.r. As articles or objects to gratify asthetic tastes

179. Plants are the source of most perfumery, and of many dyes and paints.

18(). Plants are themselves useful as ornamental subjerts. They may be grown for their effects as individuals or single specimens, as a tres, a shrub, or a plant in a pot; or for their effects in masses in the landscape.

181. Plants are useful for their flowers or ornamental fruits. The flower's may be desired in mass effects, as single specimen plants, or as ent-flowers. 'The growing of plants for their effects as individuals or for ent-flowers is floriculture; the growing of them for their rombined or mass effects in the open (or on the lawn) is landscape horticulture (9). 
170k. 'Tap-roots (Fig. 33) extend the benefits of root acion to eroat depths. They drain, areate and comminute the soil;

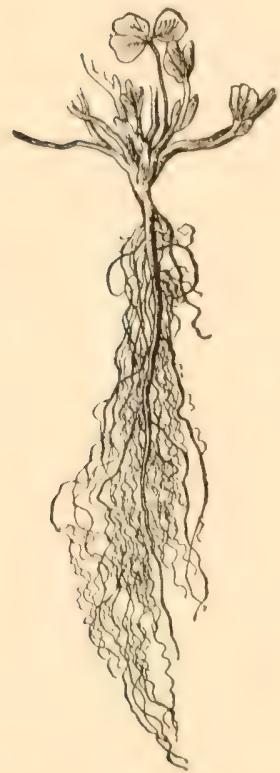

Hig. 33. 'The deep root-system of red elover.

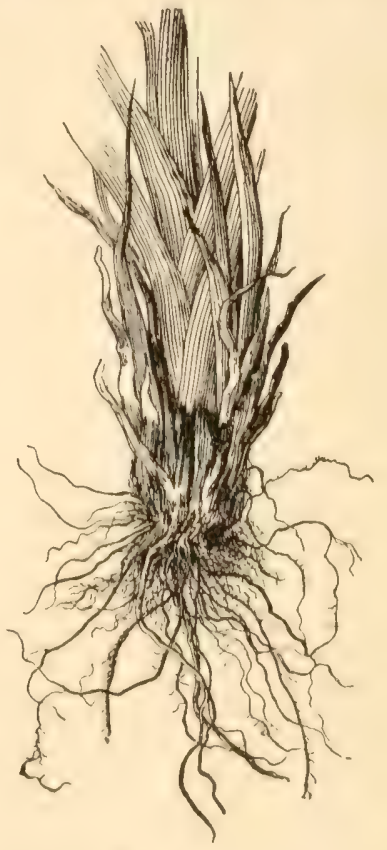

Fig. 34. The shallow root-system of orchard grass.

and the flunt-food which they bring from the subsoil is left, when the plant deeays, in such places and eondition that surface-rooted plants ean get it. With the elover, compare a grisss (Fig. 34).

171a. In many countries definite efforts are made to hold 
loose sands from drifting by winds, as atong the woasts of the sea. Sand-loving plants with strong running roots or rootstocks-as various grasses and sedges-are used for this purpose. One of the uses of windbreaks is to lessen the drifting of sands. Bhafis and railway ambankments am often held from eaving and washing by means of strong-rooted plants.

172,. Large forests probably have some influeneo in dis-

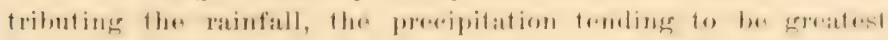
near the forest areas. By some persons it is thought that the totat precoipitation is increased by forests, but this point is in dispute. The off-1low or outflow from forest-covered, or from any plant-rovered, lands is mores gradual than from bare lands; thus floods are more frequent and more serious thre more anompletely the forests are removed. This is illustrated in the flowels on the Ohio and other rivers.

172b. Plants lessen evaporation chiefly in the capacity of

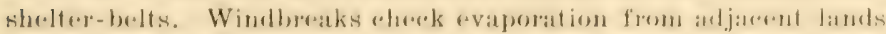
(ser King, "The Soil," pp. 204-206); and this is ono valuable

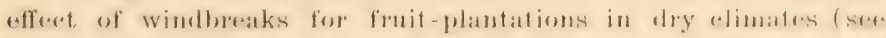

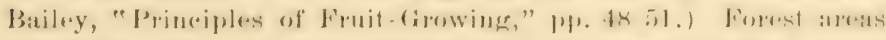
contribute some of their moisture to the stmosplese of contignous areas ; and plants give off moisture from the ir growing parts.

$173 a$. For a full discussion of windbreaks, see "Principles of Fruit-Growing," pp. 47-57, 62-92. 


\title{
Chapter VIII
}

\section{HOW THE PLAN'T LIVES}

\author{
B. M. DUGGAR
}

\section{The Plant Activities}

182. The plant is a very dependent structure: it must be supplied with water and certain soluble salts from the soil, oxygen and carbon dioxid from the air, in addition to sunlight and a certain amount of heat. When these conditions are fulfillod, - somewhat as a plant's ancestors have been aceustomed to them,the plant must grow, provided no extraneous diseases or accidents overtake it.

18:3. A growing plant is influenced by all of the external conditions about it, -it is sensitive, or manifests irritability. In studying wrowth processex, we must remember that these processist ate oremring in a highly responsive living object, an objeret with both inexplainable internal forers and with processes most favorable for chemical and physical sturly. To study how a plant lives, one must considel the important factors of growth, actual growth phe- 
nomena, and certain other conditions to which growth is sensitive.

\section{The Factors of Growth}

\section{2a. Water in the plant}

184. The rigidity or stiffuess of any herb (1) suceulent part is largely dependent on its water content. If a suceulent branch is severed, it soon loses its water by evaporation, and it becomes flaceid, or wilted. 'The proper extension, or turgidity, of the cells of plants with water is necessary for active crowth. The passage of the soil water into the plant, and thereafter its transfer from living cell to living cell, is arcomplished by the process of osmosis, which is the diffusion of liquids throngh membranes. Iuch of this water sentually reaches certain conducting parts, or bundles.

18.). Surrounding each rootlet for some distance back of the tip is an enveloping growth of delieate root-hairs. These hairs are single, tubular cells, the outgrowth of single cells in the outer layer of the root. Each one contains within its walls, as do all active cells, living matter called protoplasm, along with cell-sap. In the soil these delicate hairs push readily in amongst the soil particles, covering an immense 
amoment of spater. Owing to the densere rell-saly of the reot-hairs these hairs absorb water by osmosis. There are in solution in the soil Water minute quantities of food suldstances, and these are absorbed independently of the relative amomats fresent. 'The absorptive artivity, or full, of the root-hatirs is so sereat that water may be rextrated from a soil alparently dry.

186. Plants contain much water'; but it reguires oven temperatures, about geno F., to drive out all the water from plant substance. 'The total water in some plants, as determined by the chemist, is as follows:

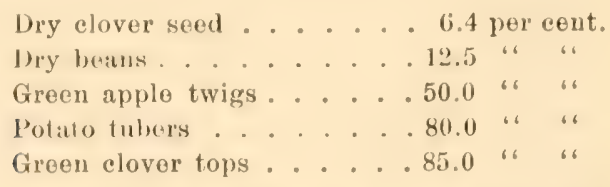

187. Water is alsorbed in ereater grantity than ean aretually enter inte the aomprosition of the living plant; and the surphus water is thrown off hy a process of evaporation known als transpriation. The water is rapidly tratsispired from

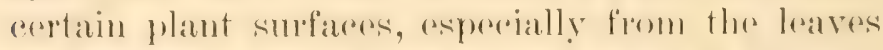
and greens stems. 'The watere compent is important; for axample, it promptly distributes foods. 188. Leaves ale proviled with thousands of

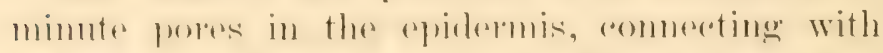
the delicate tissues within. 'l'hesse pores, or 
stomata, alre aspecially abmolant on the moler surfareses of most leaves. With rhangers in 1 he watere content of the plant, theses stomana open or closer, to at degrere fitcilitating or inhibiting transpiration. Like Papuration, transpiration is hastened by higher temperatures, dry air, wind, and the movements of the plant. On a reper lot daty, or with insuffirement soil moisture, at plant may wilt, due to the fact that all of the

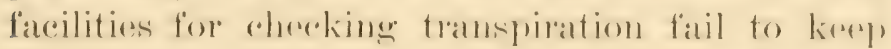

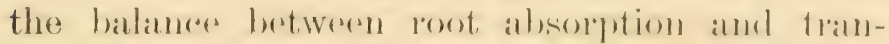
spiration. 'The plant gives off more water' than it takes up; therefore, it wilts.

18\%. 'The absomptive activity of the roots gives rise fo at salp- or root-peressure whirh temels to foree the rorent upward. In faret, the lifting power of tratspiration, osmosis, rent-pmessure,

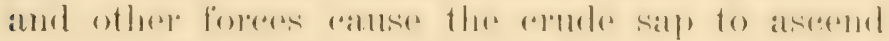
thromeh the wooly bomelles of the plant; amet by matas of theser bumbles atsomberl solutions atro

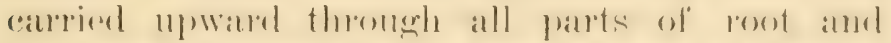
stem, and thromgh the leat'-stalk, reins and roinlets to all parts of the leaf.

\section{2b. Soluble sults from the soil}

190. Along with the soil water absophent hy the roots, minute guantities of the varions min-

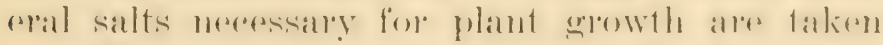
in. 'These salts are in solution. In the phant, 
these solutions become a part of the aserending silp, and they are diffused to all parts where assimilation goes on. Plants possess a reptain selecetive absonption, yet soil elements not utilized by the plant are also alsentred in creseter or less quantity depending on whethes or not depositer in inert form. (ambenice acod, and per-

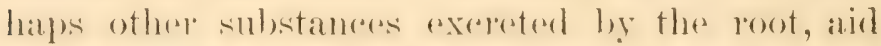
in discolving some of the mineral salts (:30).

191. Varions substances are taken in with the sorl water. Sodium and potassimm nitrate (nitre), walcium phosphate (phosphate of lime), and potassium sulfate are well-known ingredients of fertilizers. Chemical analysis and experiments show that from these and allied salts the plant

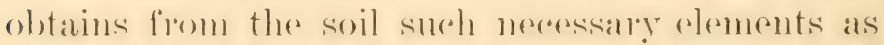
nitrogen, potassium, phosphorms, ralcinm, and sulfur. In atdition, plants also sereme from the soil tratres of iron, and whatever matenesium, sili(o) and other minesal elemente maty be meressaly.

192. Where a plant is burnerl in atr, the ash rontains all of the alone-named alements exerept the nitrogen and a part of thre sulfur and phosphorus. Nitrogen, one of the most important of plant-foorls, can be need whenly in the form of nitratese exrept in the rase of lexuminoms plants (110, 1:34), in which it is also taken form the air in some obserure way by barteria of the root tuhereles. 


\section{2c. Oxygen}

19:2. ()xyeron is assential to all of the life pororessers in the plant, as 10011 as to the animal. For

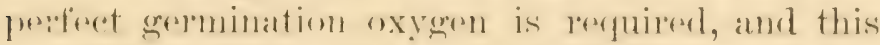
sas diffuses into and is nsed by all living of gerowing plant oregans. 'The stomata of leaves and

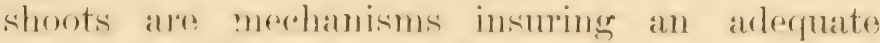
smply for these parts. Entermen these stronata, it is rarlily diffused throughout the moighboring cells and tissues.

194. ()xygen is thon constantly "alsonphed," and assorelated with this absomption is the giving off' of carbon dioxid. 'This alpmoplation of oxygon and excape of (aubon dioxid are results

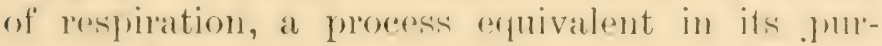
pose and results to respiration in animals. Young (rmowing plants absoll, an amomut of oxygren about. argual to thrir volunise, in forom twenty-fome to

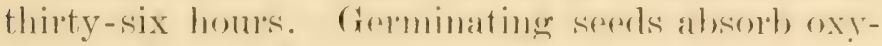
gen, and give off ordinarily almut an fefual ruantity of carbon dioxid.

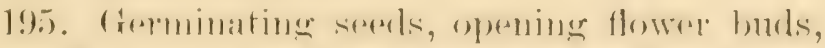

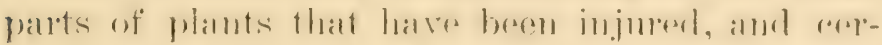

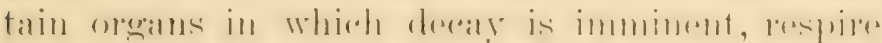

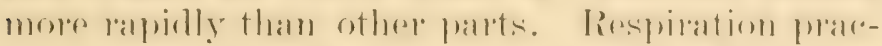

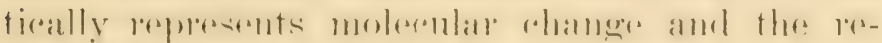
lease of energy in the living substance.

196. Oxvenen is also taken in through the

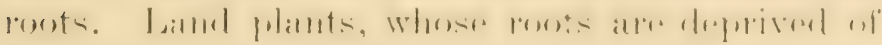


thrir air by too much water, are soon suffocated. This is esprecolally notionable in a field of Indian (o)'m or maize which has besen overflowed; and it is also a condition frecquently met with in those gronenhonses where all ahmulant use of water is the first rule. Many plants which have become aldonstomed to bogegy pregions, and many greenlomser plants, send up to the surfinee numerous ront formations in response to a need of fresh air, or oxygen.

\section{2d. Carbon dioxid and sunlight}

197. The element that is present in greatest amome in plants is arpon. This material is derived in ereen plants from the carbon dioxid (or carbonic acid gas) of the air.

198. In order to berome plant-fool, the carlon dioxid of the air first diffuses into the leaves; then its utilization depends on the green eoloring matter of leaves, -or the rehlorophyll, -amel on sumlight. The ahlorophyll absorbs some of the mereg of smoliehte and by means of the meregre thus providerl, theres is effeceted a realrramemenent of the atoms of carthon dioxid and water, surb that sugar, and ultimately stareh, mal be proflueerl and some oxyen is set free. This proeses of the formation of plant-food from raplon dioxid and water, with the eonserfuent wring off of oxygen, is photosynthesis (some- 
timos known as rarbon assimilations). It is in its pesults the reverse of pespiration, in which

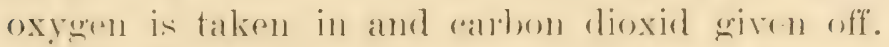

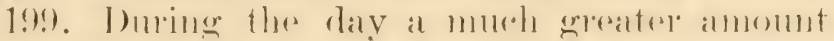
of oxyour is sot fores as a result of photosynthesis than that nerel in respiration, so that as sulplus of oxyeren aretually rliffuses into thre aile, and plants ales said to purify the air. At night, no photosyothesis woses on, and the chiof end-poroluret of respiration, ambon dioxirl, is griven off, and may be demonstrated by experiment.

\section{2\%. Heat, or a definite temperature}

20). Ileat increases the absorptive activity of the loots, the rate of transpiration, the amomut of lespiration, and the prodects of photosynthesis.

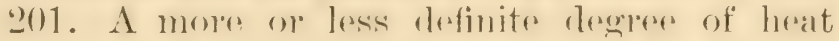
is moressisaly for all living proxerseses. As a rule, serels will not enerominate at the freroing point,

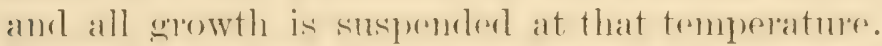
Plants grow lust within a very small lamege of frmperature, known as the optimmm trmpera-

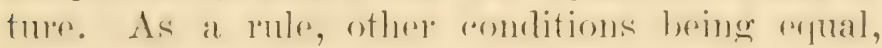

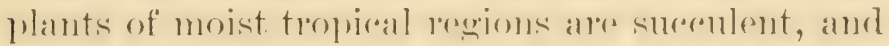

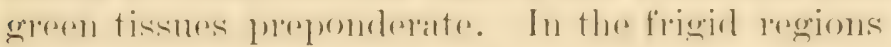

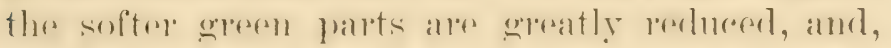
while the wordy part is of lese rextent than in

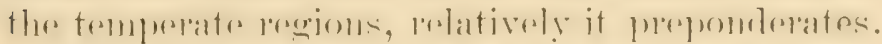

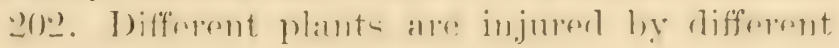


temperatures. Such plants as cotton and the melon are killed by a temperature several degrees above freezing. The living protoplasm is stimulaterl to give up its water, the roots are chilled and amnot supply to the leaves that water necasily to offiset transpiration, and, as a result, the leaves soon wilt and blacken. On the other hand, even the green parts of some plants will withstand freezing temperatures. The ability to resist cold depends primarily on the response of the protoplasm, its capacity to give up water in freezing withont injury, together with the power of reabsorption on thawing.

\section{The Processes of Growth}

203. The starch that may result from photosynthesis or the use of carbon dioxid is stored in the leaves during the day, and at night it may be (ntirely removed and used after being converted into a soluble substance, sugar. Some of this sugar is directly used in building up more complex "ompounds userl in growth, and some of it is again converted into starch and stored in tubers, stems, or thickened leaves, for futme growth puposes.

204. The extermal wirleness of errowth alre rhanges in form and size of the different parts. The internal evidenees of erowth are te be serent in the differentiation of the indivirlual a.dls of which 
the plant is composed, - new cells are marle, and others are morlifind in size or form. It is probably impossible for a plant to live without growing; but under poor conditions the growth may bes so slight that the plant is no longer of any use to the farmer.

205). The yomes stems of many plants elongate throughout the (1utive length of the growing part. But the lower lant soon reaches the limit of its growth, the rear internocle-or space between the joints-ceases to clongate, and further growth in length proceeds only in the newer parts above. 'That is, while there is an elongation or stretching of the shoot itself, this elongation gradually lessens below, so that the region of most rapid growth is constantly in the freshest and softest part of the shoot. Notice that the distance between the joints in growing shoots tends for a time to increase.

-2)6. The root mows rifforently. The tip uf the growing root is hard, hring protecterl by what is known as a ront-rall. (trowth in length takes place just hehime this hamel tij), not thromelont the length of the erowing pillt. The root, therefores, is ables to push its way alomul obstarles. 2017. In most of one woroly plants, inclease in

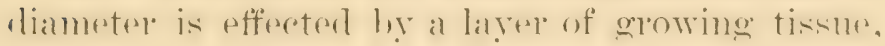
the rambinm, loxaterl just bermeath the lank: and every year it gives rise to a new layel of wood on 
the outside of the old wood, and to a new layer of bark on the inside of the old bark. Thus the heart-wool is the oldest wood, and the outside bark constantly breaking off is the oldest bark. The interior' woml takes less and less part in the aretivities of the plant, and the heart-wood of trese is nearly nseless except as a support to the plant.

\section{Irritability}

208. (rowing parts are sensitive or responsive. 'This responsiveness or irritability may be called forth by diverse external forces, and is manifest in definite movements, in growth reactions, and in complex internal changes.

209. Some plants make visible morements, and may eren be sensitive to shocks. The sensitive-plant suddenly roses its leaves and droops when toucherl; the leaves of sun-dew and other insectivoroms plants close upon their prey; and the temdil of the gomed grarlually bends around the object it touches.

210. Green parts turn towards the light, and assimilation is therely inereaserl. Plants in windows turn the broar surfares of their leaves perpendienlar to the incoming rays of light; amel a semlling grown muler a box into which light is arlmitter throngh a single slit will grow 
directly towards that slit, and even through it to the brighter light.

211. Plants are sensitive to sravitation. The iirst ront of the germinating sem is so sensitive to gravity that it ordinarily grows downward, wherever it may be and whaterer may be its position. On the other hand, the first shoot is oppositely affected by eravity, and if a potted sordling is placed horizontally the stem soon directs itself npward. While its anderal temrency is downwarl, the root is nevertheless attracted in any direction by the presence of water.

212. The reactions of plants to their anvironmonts or surroundings may cause the plants to vary, or to assmme new forms or characteristics; and these new features may be of use to the farmer. Thus, with more light, the better are thr roses or rarnations grown under glass; the richer the soil, the stronger is the growth; the hisher the altiturle of latiturle, the greater is the proportion of dwarf plants.

\section{SUGGESTIONS O.Y CHAPTER FIII}

182a. A salt is the sulstance formed from the union of an acid with some inorganice substance or hase. The salt may he neutral, - neither acid nor alkaline. Thus sulfuric acid and lime form

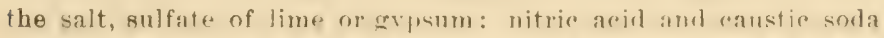
form the sait nitrate of soda; muriatic (hydrochloric) areid and 
caustic potash form muritte of potash; muriate acid and caustic soda form muriate of soda, which is commonly known as salt, -that is, it is common salt.

184a. From a potato tuber which has lain in the air until somewhat wilted, cut cireular segments about one-fourth of an inch or less in thickness. Place some of these pioces in water, and others in strong salt solution. In a short time those in

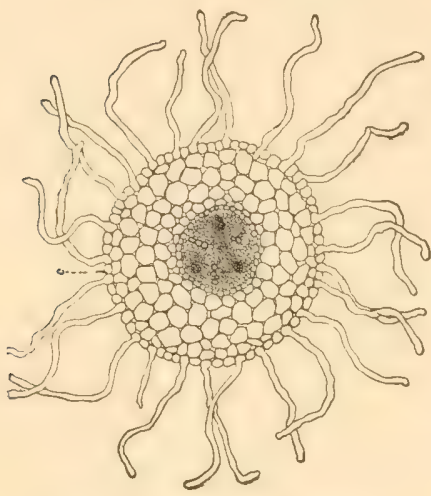

Fig. 35. Root-hairs, enlarged. water become more rigid, while those in strong salt water become flaceid. The cell-sap of the potato, containing some salts and sugars in solution, is a denser solution than the water, and the flow of water is inward to the denser solution; hence the pieces absorb water. Of those pieces in strong salt solution the flow of water is outward, and the potato segments lose some of their water and become flaceid. See Atkinson's "Elementary Botany," pp. 13-18.

185a A A cross-section of a rootlet in Fig. 35 shows the root hairs. These hitirs are seen to be prolongations of the outer or epidermal cells.

185̋b. By germinating a bean, pumpkin seed, or wheat in moss, or hetween folds of moist thick cloth, the root-hairs may be observed. Fig. 36 shows the finge of hatrs on sueh a seedling; and Fig. 37 shows how the root-hairs attach the soil particles to the root. For a longer account of root-struetures and root-antion, compare Soranel, "Physiolory wi Plants for the Use of Gardener's," pl). 4-7.

186a. Any one who has handled both green and dry fodder has a general idea of how mueh water there may be in plants. Why do apples and crapes and calbuges shrivel after they are picked?

185\%. A single evidermal pore is a stoma or stomate. 'T'he 
plural is stomata or stomates. Fig. 38 shows a fragment of leaf ir cross-section, a being a stoma opening out on the lower sur-

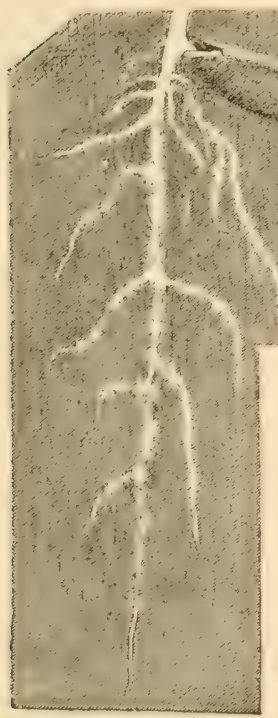

Fig. 36. The root-hairs as seen on a dark, damp cloth. face. Looking down upon the peeled-off epidermis of the lower surface, stomata are seen at Fig. 39. 1886. Cut off a leafy branch of any herb, insert the stem through a perforated cork into a bottle of water, and then place the whole under a bell-glass. Note how soon the water vapor thrown off condenses upon the glass. Compare Fig. 10, page 58.

188e. The rate of transpiration from a single leaf may be aceurately observed as follows: A large Ushaped glass tube is filler with water, and into one end of this tube is inserted a perforated cork bearing a small glass tube or eapillary arm, bent at right angles. In the other end of the $\mathrm{U}$ tube is fitted a cork, through the perforation in which is inserted the leaf-stalk, with the stem reaching the water, as shown in Fig. 40. When this last cork is foreed in, water will fill the eapillary arm; and the recession of the water in this arm to supply that transpired shows the rate of transpiration. Wax or paraffin should be used to seal around the perforations.

189a. Root-pressure or sap-pressure, may be made evident roughly by a very simple experiment. An inch o: si) alovere ground, eut off a stem of some actively-growing Lethatents plant, as the sun-

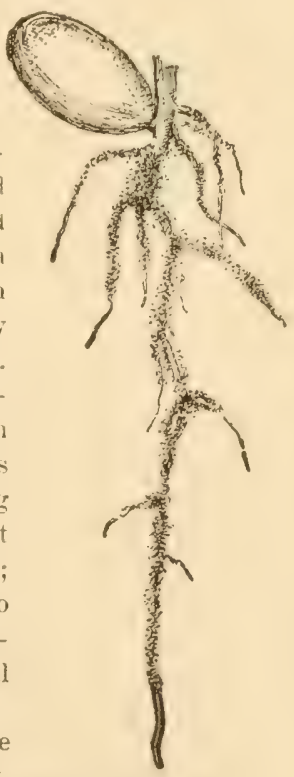

Fig. 37. How the soil adheres to the young root. 
Hlower. Fit tightly over this stub a few inches of rubber tubing, partially filling the tubing with water, and into the free end fit closely a small glass tube several feet long, supporting the tube by a stake. In a few hours water will begin to rise in the grlass tube. 'This pressure in the common nettle may sustain a column of water over ten feet in height, and in the grape-vine a column more than thirty feet in height. It is inapplieable for plants that force up only a small volume of water under high pressure.

189b. The sap ascends through the young woody parts, the sap-wood in our common trees, and not between the bark and wood, as commonly supposed. T'o note the special channels

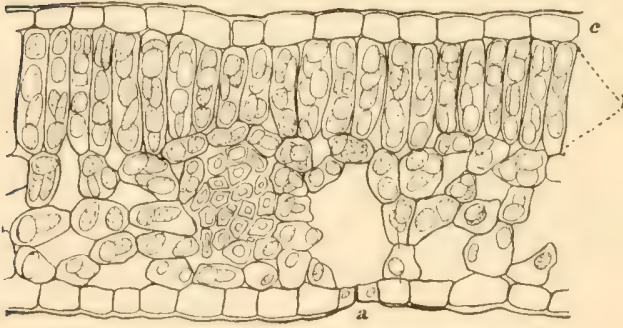

Fig. 38. Cross-section of a leaf. Stoma at at.

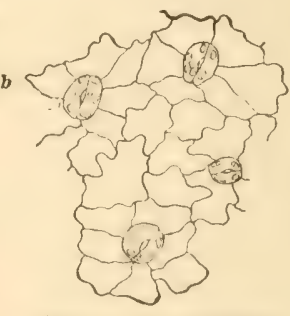

Jigr :ti. Fomr stmmalit.

throngh which sap ascends, secure a few joints of green corn, a blade of celery, a leaf of eamna, and some woody branch, and put the stem ends into a tumbler with a solution of some red dye or stain, preferably eosin or fuchsin. Often in the course of a few hours there is exterual evidence that the colored liquid ascends through definite channels, at least with the suceulent herbs. Now ent of the stems and note the colored regions,in the corn those thread-like groups of fibers so noticeable when an old cormstalk is broken ; in the cetery, likewise, through those etringy fibers known to all who have eaten tough celery; and in woody plants, through the layers of wood nearest the bark.

$190 a$. For fuller discussions of the subjects ontlined in 190 and 191, consult Soraner, "Pliysiology of Plants for the Use of Gardener's," pp. 30-44, 48-51. 
194a. Air in which seeds have been germinating has suffered a change; this can be shown in the following manner:- Fill a large-mouthed bottle half full with soaked heans or peas, add a small quantity of water, and cork it. After twenty-four hours, pass a lighted wax taper or waxerl cord into the jar, and it will be

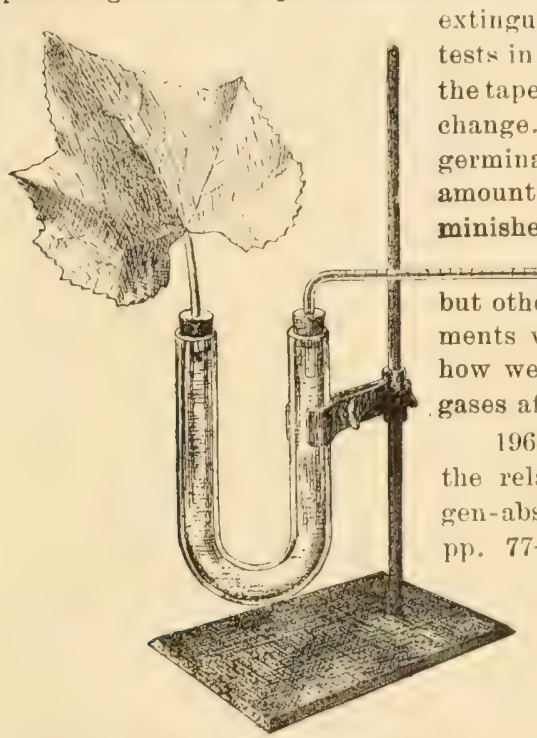

Fig. 40. Means of showing transpiration. extinguished. Make the same
tests in a jar of air, and see that the taper burns. This is a striking change. As a matter of fact, the germination has increased the amount of carbon dioxid and diminished the amount of oxygen,

but other more elaborate experiments would be needed to show how we know that these are the

196a. For a discussion of the relation of wet soils to oxygen-absorption, read Sorauer, p. $77-80$.

1962. The "cypress knees" which project from the water in eypress swamps in the South are supposerl to be aérating organs.

197a. If a plant is burned in the air, the resulting ash is very small; lout if burnet without free access of air, as in a charcoal pit, there remains a charred mass almost as great in volume as the substance burned. This mass is largely carbon, a most important element in all living matter, or protoplasm. In combination with the elements of water, rarbon aliso forms most of the rellular tissue: of plants, likewise the starches and the sulgars, all of which are ralled cartohydrates. The manufacture of theses stareh-like comprounds by the appropriation of the carbon dioxid of tise air is 
one of the pesuliarities of green plants; and animals depend on plants for the preliminary preparation of theso necessary compounds.

194r. The word assimilation is sometimes used in this restricted

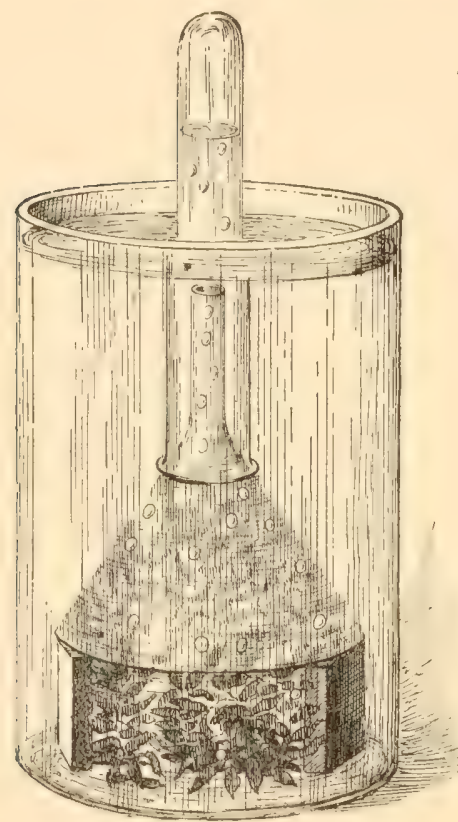

Fig. 41. Experiment to show the griving off of oxygen. sense in plants, as defined in 198. In general speech it means the appropriation of prepared or digested food, as the assimilation of the food by the blood, or protoplasm.

198b. Chlorophyll is the green coloring matter of plants. It looks to be in the form of minute grains. Most of the cells in Fig. 38 contain chlorophyll grains.

198c. Plant-food, in the sense in which the term is here used, is a product of photosynthesis,-sugar, stareh or some similar material. In common speech the term food is used to designate any material taken in and ultimately used by the plant, as nitrates, potash, water; and a general use of the term is so well established that it cannot be overthrown.

1981. For further light on assimilation, compare Arthur and MacDougal, "Living

Plants and Their Properties," pp. 145-152.

199a. Place under a funnel in a deep beaker, containing fresh spring or stream water, growing bits of water-weed (Eloden (andalensis), and invert over the ent of the funnel a testtube filled with water, as in Fig. 41 . In the sunlight bubbles of 
gas will be seen to rise and collect in the tube. If a sufficient quantity of this gas could be quickly collected, on testing it with a lighted taper the Hame would be seen to quicken per-

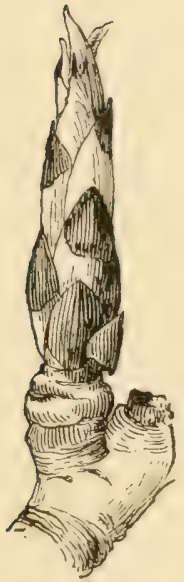

Fig. 42. Opening of a but of pear.

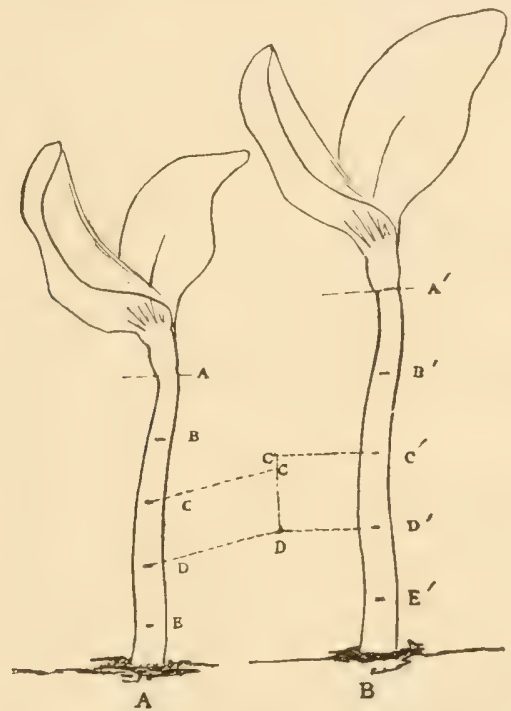

Fig. 43. The marking of the stem and the spreading apart of the marks.

reptibly, indicating more oxyen than is contained in the air. In this case the carbon dioxid used is in solution in the water. 'The Elodea is common in still ponds.

201a. On the subject of temperature and plant life, compare Bailey, "The survival of the T'nlikt," In' $4+48$, Chapters xrii. and xix.; and Chapter xiii. of Gaye's "Great World's Farm."

$202 \ell$. Compart Arthme and Maciougal, "I Jiving Plants and their Properties," $\mu$ r. 85-9s, for a discussion of the influence of cold in injuring plants.

203a. To test for starch in a potato tuber or other storage 
organ, spread a drop of tincture of iodine on the eut surfice. and the blue"or violet color indicates the presence of starch.

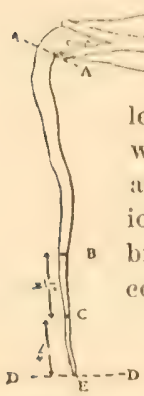

Fig. 44.

Marking the

root.

Test the laundry stareh.

2037. 'J'o determine that stareh is formed only in the green parts of leaves, secure a leaf variegated with white, like a coleus or geranium, which has been some hours in sunlight. Place it in hot aleohol nut il the green color disappears, and then add some. iodine. The parts which were green aro colored violetbrown, indieating stareh, but the white parts aro uncolored. Another loaf eovered with dark eloth for twenty-four hours will show little or no starch axywhere, indicating the removal in darkness of the stareh formed in sunlight.

204a. The opening bud of a beech is a good examplo for observation of growth, as it expands from day to day. The long seales of the winter bud become looser, and gradually, by the elongation of parts botween them, the seales are foreed apart, showing at the base of each a minute leaf of perfect form. Daily tho leaf increases in size, the internodes or stem portions between the leaves elongate, the seales fall away, and from a bud of an inch in length, by elongation throughout its whole extent we have a leafy twig of many inches, with a terminal bud, and a bud in the uxil of' each leaf. 'The beginning of the spring mowth is likewise well shown in the pear bud, Fig. 42. Consult Bailey's "Lessons with Plunts," pp. 44-72, for fuller discussions, with many illustrations, of the opening of buds.

205u. Mark a young stem, as at $\Lambda \mathrm{in}$ Fig.

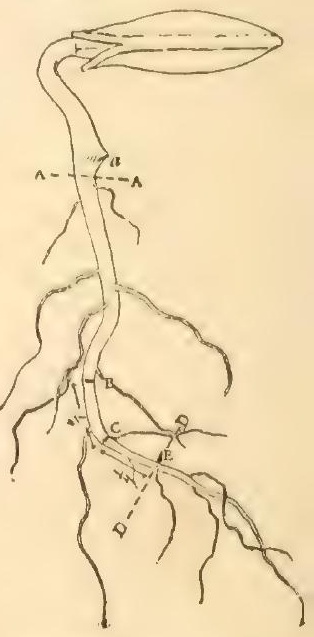

Fig. 45. The root grows in end nortion. 13; but the next day wo shall find that thewe marks are farther apart than when we mado them (B, Nig. 43). The marks have all raised themselves above the ground as the plant has grown. 
The stem, therefore, has grown throughout its length rather than from the end.-Bailey, "Lessons with Plants," p.322.

206re. Germinte a sciulsh seed between layers of blotting-paper or eloth. When the root has grown an inch or two lay the plantlet. on a piece of paper. Then lay a rule alongside of it, and makes a mark (with indelible ink) one-quartor of an iurh, or less, from the tip, and two or three other marks at ayual distances above (Fig. 41). Now earefully replatee the seed. T'wo days later, examine it; we shatl most likely find a condition something like that in Fig. 45. It will be seen that the marks $k$, (:, B, are practieally the same distance apart as before, and they are also the same distane from the peg, A A. The point of the root is no, longer. at I) I), however, but has moved on to F. - liatey, "Lessoms with Plants," p. \$21."

$207 \pi$. We now see that the "sap" of trees is a very complex substance. It is the juice or liguid in the plant. The ligning which first comes in at the root is water, with very dilute proportions of various substances. But the sap also carries the products of assimilation to all parts of the plant, to build up the tissues. In eommon speech, tho upward-moving water, recently taken in from the soil, and known as tho "transpiration stream," is often called erude sap; and the liquid carrying sugars and other organic compounds is ealled elaborated sap.

20 gre. See the diseussions and pietures of moving parts in Bailey's "Lessons with Plants," pp. 396-4106; also Barnes' "Plant Life," pr. 188-208: Atkinson's "Elementary Bostany," pr. 82-92; Arthur and Maclongal's "Living P'lants," Chapters i.-iv., and other botanical treatises. 


\section{Chap'ter TX}

\section{"WH PROPAGATION OH' PLAN'T'S}

\section{The Kinds of Propanation}

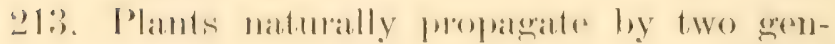

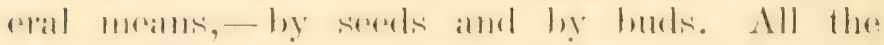

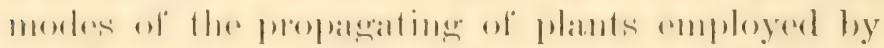

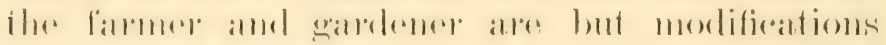
of these two general types.

214. 'Ther lammer has these ohjerets in view in

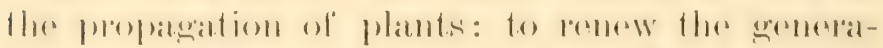
tion, or to prevent the stock from lyiuger ont; to imerease the mumber of plants; to perpetuate a

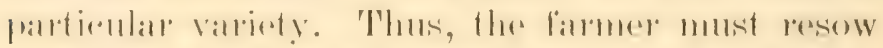
his wheat, of he will lose the storek; hut he ax-

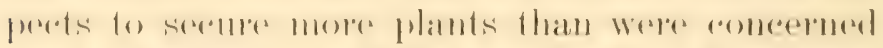
in the foredertion of the sered which he sows;

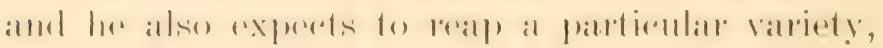
as Diohl or Moditerranean.

215. Seeds are always able to preserve the race or stock and to increase the number of plants, but they are not alwatys able to produes

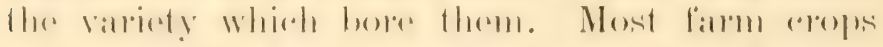

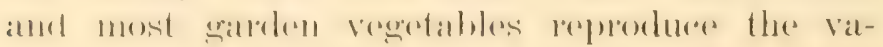


roofy firom sorols; hut most fruts and forese and

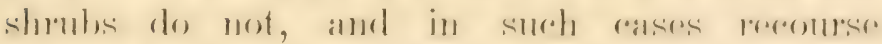
is harl to burl poplagation, as layrors, rattingers, grafts.

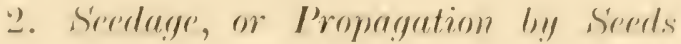

\section{2a. Rernisites of germiuation}

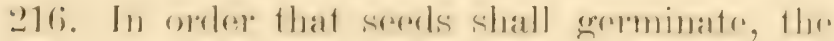

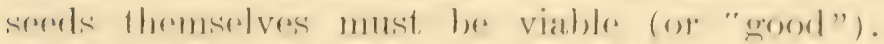
Viability depmols mpon (a) thr matmeity of thro soreds, (b) forshomesis, - thery shall mot have losel thrir vitality through agere, - (r) thre viger allol

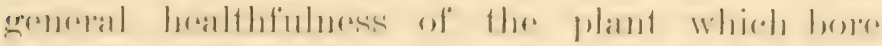

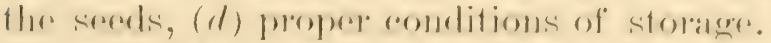

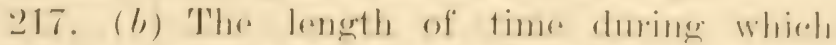

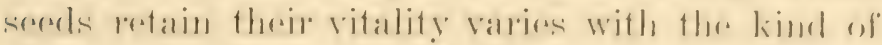
plant and with the eomditions molro whirels thr.

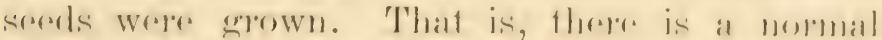
vitalify and an inrojdrutal vitality. Mrest sorols

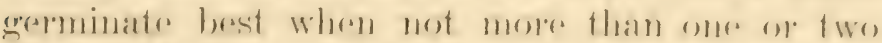
yoars old, hut rotain stromere vitality there ole

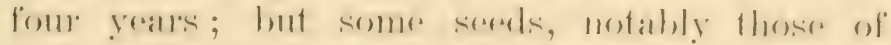

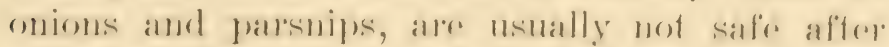
a year old.

218. In ordre that serels shall gerrminatr,

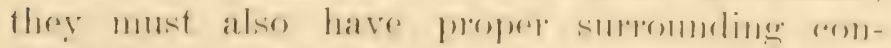

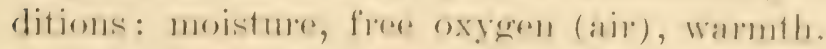


219. 'The irleal condition of the seed-bed, so far as water is concorned, is that it shall be moist, not wot. IVet soil injumes seeds, largely by exchuling axyente. The older and weaker the secds, the meater is the necessity for "are in applying watere: they shomlel be kept omly slightly moist motil germination is well starterl. 'The soakine of serels starts the germinating procosses, but it shombl not be contimued ahove twenty-four homs, as a rule, and should not be employed with very weak seeds.

200 ( )

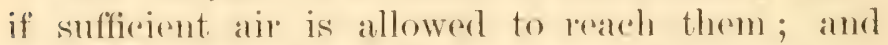
the air learohes them if they are not planted too deep, nor kept too wot, nol the soil allowed to "hake." But all these conditions are encatly modified by the kind of soil.

201. For aroh kind of seed there is a certain degres of warmth under which it will germinate to the hest advantage ; and this is aalled the optimum temperature for that seed. The optimum temporatume is not miform or exact, but rangess thromerh a limit of tive to ten degrees. Soreds of most hadrly plants-as wheat, oats, rye, letture, rathisere, and wild plants-germinate best in temperatures hetwen $45^{\circ}$ and $65^{\circ}$; those of temelel vereotaliles and conservatory plants, hetwern $60^{\circ}$ and $80^{\circ}$; those of tropical plants. between $75^{\circ}$ and $95^{\circ}$. 


\section{$2 b$. The raising of seedlings}

22.2. The ideal soil in which to plant seeds is loose and friable, does not "bake," and is reteritive of moisture. It is neither hard clay nor" loose sand.

2.23. The looser the soil, the deeper the serds may bo planted, since the plantlets can easily push through the earth; and the deeper the planting the more miform is the moisture. For seexls of medium size and of strong germinating power, -as wheat, cabluage, apple, - a quarter or half inch is suffirent depth. In order to secure moisture about the seseds, the earth should be firmed or parked overe theme, particularly in a dry time; but this surfare wath is moist becauses water is passing through it into the air (10\%), 104).

204. The smaller the sered, the shallower should it be somn, as a rule, and the crreater should be the care in sowing. Very small sorols, as those of begonia, shomld le merely pressed into the earth, and the surfiace is then kept moist by sharling, laying on a paper, rototh or erlass, or by very arefoul watering. Delicate seesls are often sown on the surfaces of wedl-firmed

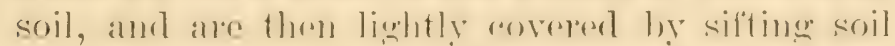
or dry moss over thrm. Kone them sharled untii germination is well progressed. 
205. Seerls may regerminate. That is, if germination is arrested hy drought, the process may be renewed when rongenial conditions recur, even though the young root may be dried and dead. This is true of wheat, oats, maize, pea, onion, buckwheat, and other seeds. Some seeds have been known to resume oremination five and six times, even when the rootlet had grown half an inch or more and the seeds had been thoroughly dried after each regemination.

226. Bony and nut-like seeds must generally be softened by lying long in the rarth; and the softening and splitting of the coverings is hastened by freezing. Siuch speds are peach pits, walnuts, haws, and most tree seeds. Gardeners bury such seeds in earth in the fall, and plant them the following suring. The seeds are, also, often mixed with sand, or placed between layers of sand in a box, and if the seeds are from hardy plants the box of sand is placed where it will freeze throughout the winter. This operation is known as stratification.

\section{Propagation by Buds}

3a. Why and how bud propagation is used

227. When varieties do not "come true" or do not reprorluce themselves from seeds, it is neces- 
sary to propagate them by means of buds. In some cases, also, seeds are not produced freely, and then recourse is had to buds. In many instances, too, as in grafting, quicker results are obtained by bud propagation than by seed propagation. One means of dwarfing plants is to graft them on kinds of smaller stature.

228. Of hud propagation, there are two general types, - that in which the bud remains attached to the parent plant until it has taken root, and that in which the bud is at once separated from the parent plant. Examples of the former are layers; of the latter, euttings.

\section{3b. Undetached buds}

229. A layer is a shoot or a root which, while still attached to the plant, is marle to take root with the intention that it shall be severed, and form an independent plant.

230. The layers are bent to the ground, and at one place or joint are covered with earth; at this joint roots are emitted. Layering may be performed in either fall or spring, but the former is usually preferred. The layers are usually allowed to lie one season before they are severed. Almost any plant which has shoots that can be bent to the ground can be propagater by layers; but the best results are ohtained in plants which have rather soft wood. 


\section{3c. Detached buds}

231. Of propration by detached buds, there are two types, -buds which are inserted in the soil or in water, and those which are inserted in another plant. The former are euttings; the Iatter are grafts.

2:32. Cutting may be made of soft or unlife woorl, of of hard and fully matured wood. ()f the soft kinds are euttings (or "slips") of (ratrimms, furlsias, and the like. Of the hard kinls arre cuttinges of grapes and currants.

2:3:). Soft ruttings are marle of shoots which are sulfirinutly mature to break or snap when bent double. They eomprise at least one joint, and semetimes two or three. The leaves are removert from the lower end, and if the mperer leaves am larege they may be ant in two, or shrarred, to prevent too rapid evaporation. A

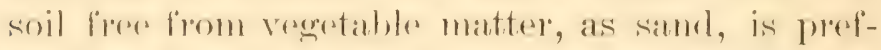
erable. It is enemoully mecessary to sharle the cuttings mutil they are established.

s.it. Inalwool or dommant cuttings ane taken in fall or winter. 'They ustally amprise two or more buts. 'They root bettor if they are callused (partially hraled wer on the bottom encl) before they are planted: therefore, it is anstomary to bury fhom in samel, or to stame them in same, in a cool collan until spring. In 
spring they are sat into the ground up to the top bud.

2:35. Single-eye ruttings-that is, one-bur ruttings-alle sometines employed when burk arrescarre, as in now or pare plants. These are usually starterl under glass. 'They are planted half an inch or an inch derp, in an ohligne or horizontal position.

2:36. (x)afting is the operation of making one plant, or a lart of it, solow upon another plant. The gart which is tamsferesed or transplanted is the rejon; the plant into which this part is transplanted is the stock.

2.:37. A cion may rontain one hud or many. It may lor insertexl in a releft or split in the woorl of the storek, or it may be insereded hertweren the bark and woorl of the stock. A single bur which is insertorl between the bark and worel is terelnirally known as a "hud," and the poreses of insertine it is known as hudding; hut bulding is only a spereial kind of grafting.

2.:3. Ther rom and stock mite berance the rambinm of the two errow together". This cambimm is betweren the bark and the wond (207): therefores it is important that the inner face of the bark of the rem (or howl) be applied to the surfiare of the wored of the stork; or, if the reine is inserent in a cortt, that the line between the bark, in the two, come together. 
239. Whon the abon is insterterl, thes wommeles surfaces most be tightly colosed, to prevent the

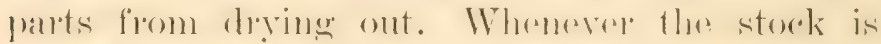

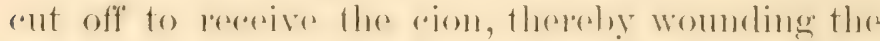

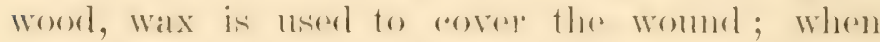

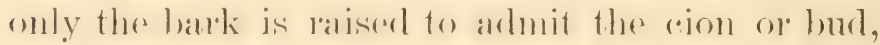
a bandage is used.

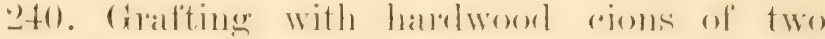
or more hords-which is mstally spoken of as

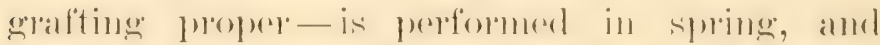

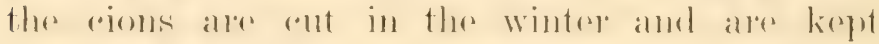
firesh amd dommant (as in a collale) motil wamberl.

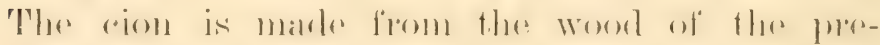

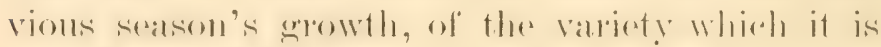
desired to propagate.

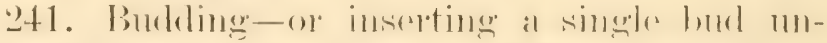

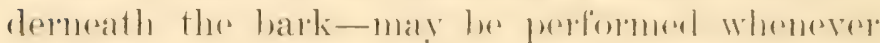
the bark of the stork will poel of "slip," and

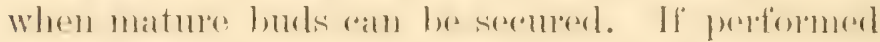

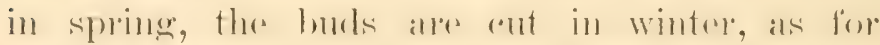

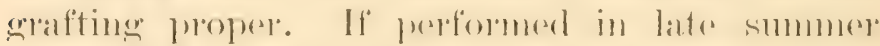
or early fall-and this is the antom-the buds are ent at the time, from the sorason's grouth.

\section{SUGGESTIONS OV CUADUER IX}

$215 a$. It is impracticable, in this connection, to explain fully why it is that some plants " come true" from seed, and others (as apples, strawberries, roses) do not; but the enquirer will find the matter expounded in Bailey's "Plant-Breeding," pp. 
88-91. The reason is that in plants which are habitually propagated by seeds, as the garden vegratables, we are constantly disearding the forms which do not come true, and are thereby fixing the tendency to come true, - since only the individuals which do come true are allowed to perpetuate themselves. In plants which are not habitually propagated by seeds, this selection does not take place, and the tendency to come true is not fixed.

217a. The longest-lived seeds are those horne on plants which reach their normal, healthy development. Those produced in very dry years are apt to have low vitality. Seeds should bo stored in a dry and fairly

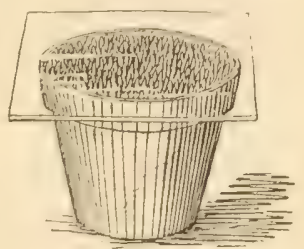

F'ig. 46. Seed-pot, covered with glass. cool room. 'lables of the longevity of garden seeds may be lound on pp. 104-107 of the 4th edition of "Horticulturist's Rulo-Book."

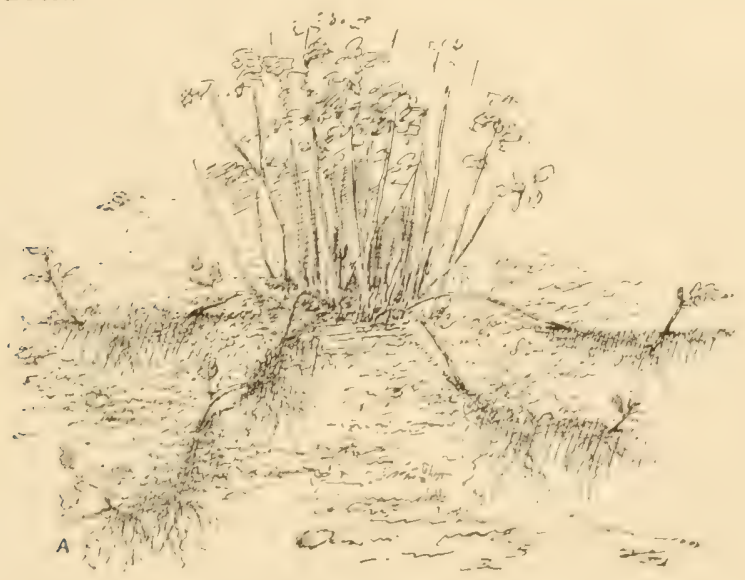

F'ig. 47. Four layered shoots.

219a. "Nursery-Book," pp. 1-7, diseusses the means of regulating moisture, with illustrations.

2.0u. As an experiment, plant coru u foot deep in warm, 
firm soil. Run a little stick or splinter down to some of the sereds, allowing it to romain. 'The air anters alongside the stick.

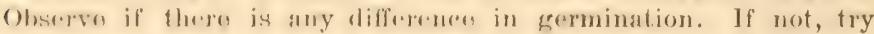
it when tho soil is very wet.

2y.ta. Vory small seods aro ofton sown vory shallow in a pot, and a pano of glass is laid over the pot to eheek evaporation (Nig. 46). As soon pour, the gratas is rotaiked directions for the noo tho "Nursery.Book,"

w30a. An illustragivon in Iis. 47. 1'our. shoots aro layered. One shoot, $A$, is layored in

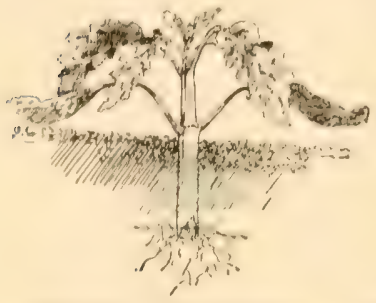

Fig. 48. Coleus eutting $\left(x^{1} /: 1\right)$.

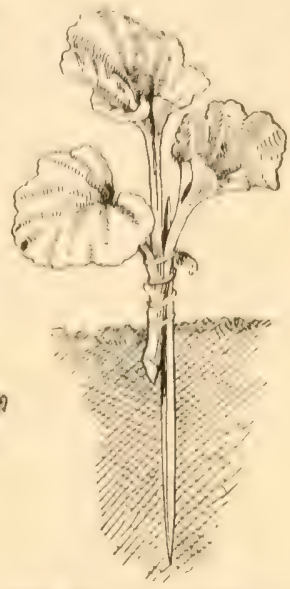

Fig. 49. Cutting hold by tooth-piek $\left(\mathrm{x}^{1 / 3}\right)$. as tho pluntlets apmoved. For desowing of seeds, (). 15-25. tion of layering is

two places, and two plants will rosult. Whon the layors havo taken root, the part is soverod and treatod as an indepondent plant. Jloneysuckles, lilacs, snowballs, and many common bushos ean bo layered with ease. Soe Chapter iii., in "NurseryBook," for full diseussion.

233 a. 'These green cutting may be planted in shallow boxes of sand, in coldframes or hotbeds, or in tho bonch of a glasshouse. Figs. 48-50 illustrate the process.

2344. A gripe entting is shown in Fig. 51. 'This is tho common lashion for propagating the grape ; but new varieties are oftan mown form single eyes, as shown in Fier. 5's. Consult 


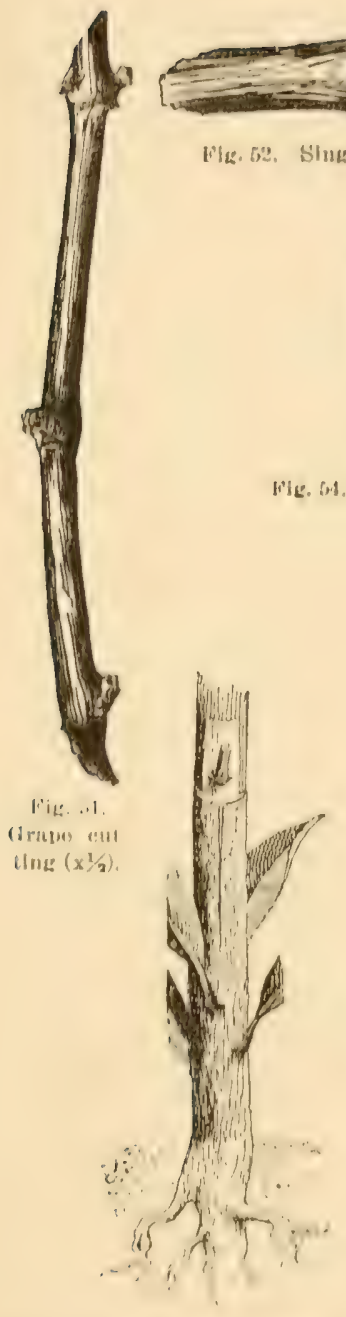

Wlo. bis. Bud entering uatrix $\left(x^{1 / 2}\right)$.

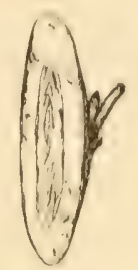

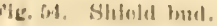

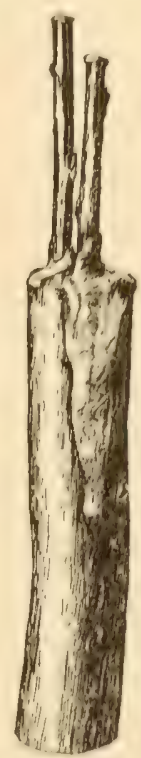

Fitg. Gos. A waxusl ntub $\left(x^{1 / 2}\right)$.

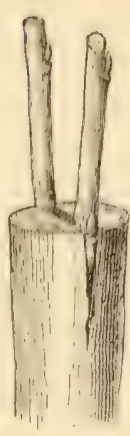

Fis. 5i3. Cleft. eruftints.

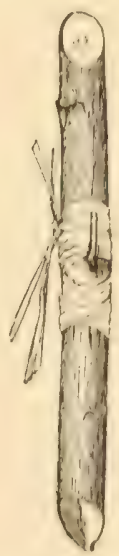

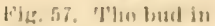
Pite. bis why h havenl down unlil eov ereed liy the burk mul now tial with bust. 
Chapter iv. of "Nursery-Book," for full directions for making and growing, euttings.

238a. Two cions inserted in a cleft in the stock are shown in Figr. si:. The "atmbium layers come together in the cion and the stoek. A "hurl" ("ion is shown in Fig. 54, and the operation of shoving this down between the bark and wood of the stock is seen in Fig. 55.

"39a. 'T'he waxing of a stock is illustrated in Fig. 56. The tying of a bud (by soft cord or bast) is shown in Fig. 57.

"240\%. 'The rommon style of errafting is suggested in Figs. 53 and 56. This is known as choft-grafting, from the splitting of the stork. It is the style nearly always employed in orchard trees of apples and pears.

"4la. Shiold-budding is the common style. It is illustrated in Figs. 54, 55, 57. 'Jhe buds are cut at the time of the budding, the leaves being alt onee taken off to prevent evaporation; hut a hit of the loaf-stalk is usually left to servo as a handlo, as secon in the picture. P'eaches, cherries, plums, oranges, are asually budded.

2416. In all kinds of grafting and budding, the operator must he careful lo seleret cions, or huds, from only those varieties which he desires to perpetuate. The stocks used by nurserymen are seedlings; but even if the plant is grafted, it can he grafted again, the same as if it were a seedling. In most mists, at variety is grafted on another plant of the same general kind, as a peach on a peach, an apple on an apple, a plum on a plum; but there are cases in which one kind or species is frialfed on a rlfferent speecies: (a) to seemes a dwarf plant, by erralting on a slow-growing root (as pear on quince), or $(b)$ be"athe sereds of the given spereses are rate, and a closely related stork is therefores sulstituted. For extended accounts of budding and graftiug, refor to "Nursery-Book," Chapter v. 


\section{Chapter $\mathrm{X}$}

\section{PREPARATION OF' LANI) FOR 'THE SEED}

\section{P. ROBERT'S}

\section{Hactors Which Inetermine the I'reparation of the Seed-bed}

242. Faulty preparation of the land is the rause of more failures than the subsequent treatment of the arop. In field ronditions, this preparation "an not be so thorough, of so ideal, as in garden areas or in glass-homses. The general condition of the farm work dietates to a creat extent the partivolar time when the seed shall be sown and the amomit of preparatory work which shall be put on the land: therefore, it is very important that the famere fully understand what is required, in order that. he may make no mistakes.

243. The preparation of the land for seeding should be coverned by two farctors: by the needs of the partirular plant which is to be grown, and by the rharareter of the land. To prepare a seed-bed for any ("rop, the habits, likes and dislikes of the plants should be 
studied. That is, it is not enough that the land be well prepared: it sheuld have the kind of preparation which is demanded by the arop.

\section{The Demands of the Plant}

24t. The prepalation of the sered-berl differs with the way in which the plant is popagated. some plants are propagaters by a piece ol part of an molereground stem or tuluer, as the potato; others ley a brameh of the arerial part, as the willew or surar-rature. In all of these earses, the buts or ayes are smomomeded

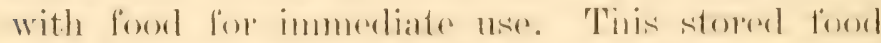
grives them power to semel ont stromes shoots and 10 grow for some time withont having to secule momishment from the soil. But many plants are forpagater ly tiny soreds. Theses start in life with little stomed foorl, and, therefore, must furckly seroure momishment from the soil; and the lamel must, therefore, be very well prepared. Therse serels should be planted matre the surface, for there will not be strength anough in the infant plant to push its way thromeh, if planterl as deep as the potato.

245. Plants may ohamere or modify their characteristies to aldipt themselves to chameres conditions. 'The common red clover is a talprooted plant, lut if it grows on soil which is 
molerlaid with wet relay, it trouds to beromes fibrous-rooted. Hown long-lived permulats, as treese, do best when the surface soil is well prepared to a depth of ten to twolve inches, since many foreling roots of trees, esperelally of yomer ones, find nomishmont in this prepared soil.

246. Plants diffor erroatly, however, in ahility to adapt themselves to unfavorable conditions. Many common plants send thrir tap-roots into the subsoil for two to three feert, aven if it be hard, while sugar beets berome fibons-rooted, and may be pusted up and partly ont of the gromal if their tap-poots attempte to entre the molisturted hard subsoil. Lamd devoted to colover need not necessarily be subsoilod if it be fairly free from stagnant water, while that planted to sugar brets should loe subsoiled, for the rasom that a lomer fusiform root is desimed, all of mearly all of which should be below the surfares; for that part of the beet which grows above the gromed is not nearly so valuable for making sugar as that part which grows under ground.

247. Nearly all of the enmmon and quickgrowing plants serome the larger part of their nomishment and moisture form the first, or surfares forot of soil. This beingeso, it is seren how nesersilly it is to prepare the soil in thre hest possible mamner. If the upper soil is not well 
prepared, the roots must seareh wide and deep for food.

248. Most of the smallere plants respuire but about six months in which to grow and to fruit. If', in order to sermere nomishment and mosisture, the roots are obliged to dexerend inte the cold, hard subsol, where the plant-food is likely to be least alvalable, neither growth nor froitage "an le satislatedory. Those plants which do not matture until they are five to twenty years of age, as

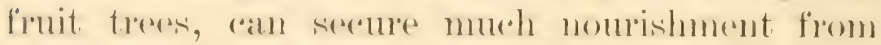
the subsoil, although they seroure little in any one growing season. 'Then, too, trees must serure a firm hold on the land, or they will be postrated by winds. By being obliged to send many of their roots into the aold, firm subsoil through many generations, treses have probably arcpuired the power of serming more of the tough or mavailable food of the subsoil than plants which live but one season.

249. Different plants respuire not only to bes planted at different seasoms of the year, but at different depths. They demand different methorls of preparation of the surfare soil. Some do best when placed in loose, warm soil, as, for instanoe, maize and sweet potatoes; while others do best when grown on fairly rold and sommhlat rompacted surface soil, as winter wheat. 


\section{The Preparing of the Seed-bed}

250). Nearly all plants thrive best when formnished with a full and rontinuous supply of moistmere Fine, looseresth, which reontains a morlerate armixtmo of hmmus, is calpalle of holding much moistume (7:- 74); but the soil may be so loose and lighte as to ardmit too rapid movernent of air, in which asse the moisture will be carried away. If the partieles of ratth are separated too widely, mapillarity is weakenerl. In surch cases the sulsurface soil shomld be slightly emmareted, while one to three inchess of the surfare is left looser to form an auth-mulch, which tends to prevent loss of moisture hy evaporation. 'The particles of the loose surfare earth-mulch should be so wirlely separated that the mosisture can colimb only to ther bottom of it, for if it comes to ther surfare the air will carry it away (8:3). 'The earth-muleh sharles the gromed in which the plants are glowing, prevents the soil form romeking, and saves moisture.

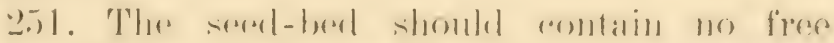
watere; hut it is impossible to serente this rondition at all times. No seromes hamm may comms when thre soil is over-satmattal at planting time,

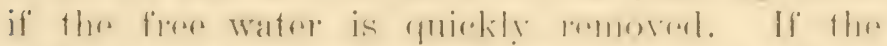
soil montains more water than it atu holed by 
capillarity, the air is driven out, and the soil swells and tends to become puddled (81).

25:. Many seeds will not germinate if planted out of season, or when the soil is cool, no matter how well the seed-bed is mrepared. Then, if it is desired to plant early, make the land fine and loose, for in so doing the temperature of the soil is raised. The soil of a fine, porous seedbed, resting on a well-drained subsurface and subsoil, is much warmer than one resting on a compact, undrained foumbation. However, it is not wise to plant seeds out of season or when the weather is unsuitable.

253. If small seeds are covered with but little earth, they may fail to germinate for lack of moisture. If covered with enough fine earth to insure a constant supply of moisture, the young plants have a hard struggle to reach the surface. Only a few of the small seeds, as clover and many of those planted in the kitchen-garden or Hower-garden, ever produce plants. Sometimes the seeds are imperfect, but more often the failure to secure vigorous germination is due to a poor seed-bed or to eareless planting. To obtain better results, not only prepare a fine seedbed and sow at the proper time, but compact the soil immediately orer the row of seeds. This will enalue appillan'y attration to bring moisture to the surface, or near it (10):?). Thes 
earth-mulch should remain unpacked between the rows, to conserve moisture.

254. In some cases it is impossible to secure a proper seed-ber for small seeds. For example, no suitable seed-bed can be procured, as a rule, for clover seeds when sower in a growing tilled crop. In order to secure germination, these seeds are sown on the surface in early spring, while the surface soil is still porous from winter freezing. The spring rains wash the seeds into the little cracks in the soil and partly cover them. The weather being cool and clonily and the soil moist in early spring, the oily seeds of the clover are kept damp enough to insure germination. If such small seeds are sown in summer or early fall, the land is rolled for the purpose of supplying them with moisture.

25.5. A good field seed-bed, then, can be secured profitably only on land which is either naturally or artificially well drained, which has been well broken and ermmbled by the plow, and the surface of which has been thoroughly fined hy the harrow. Particular care should be taken not to work heavy or clay lands when they are wet. Neither should clay lands be tilled so much that they become very dusty, else they will puddle when the rains come. The remarks respecting the proper tillage of the land (Chapter iv.) will apply here. 


\section{Application of the Foregoing Primeiples}

4a. Whert

2.xti. Winter wheat does best when one or two inches of the surfine soil is fine and loose, and the subsurfare soil line and fairly comparet.

257. To secure the ideal conditions, the ground should be plowed some time before sowing, and the manure spread on the rough surface. 'The ground is immediately harrowed, rolled, and harrowed again. In one or two weeks afterward it is surface-tilled again, with the implements best suited to the particular soil. All this tends to divide and cover the manure, compact the subsurface soil, form a fine seed-berl, conserve moisture, and set free plant-food.

ass. This trobtment of the land ratses the roots to the many and fibroms, and to remain near the surlatere, where the plant-food is most abmolant and atralable. If the manure is plowed moler and the soil remains loose, the roots are less fibrous and deseend to the hoftom of the lorrow. In the springe, it often freages at night and thaws during the day. This tomds lo lift the plants and to broak their roots. But if the roots are nearly horizontal and near the sulfiere, they troul to rise 
and fall with the freezing and thawing, and are not seriously injured.

259. As the soil becomes hot at the surface in June and .July, the shallow roots descend to the subsurfaces soil, where it is cool and where the plant-food was not drawn upon during the fall; while the deep fall-rooted plants will be unable to find new feeding ground when they need it most, just before fruiting, unless the roots start toward the surface, which they will not do, for in mirlsummer the surface soil is hard and dryish and too warm for wheat roots.

\section{4b. Maize, or Indian corn}

260. The seed-bed for maize, which is a sunplant and does best when planted in a warm soil, may be prepared in a different way from that designed for winter wheat. Since maize is planterl in the spring, when the soil is oftron tor, rool for this semi-tropical plant, the subsurfare soil should not be as comparet as for wheat. If left rather open, the wam spring rains pass quickly to the subsoil and wam the soil (7T). The more open seert-berl will allow a freep cirertlation of warm air through the soil.

261. The best malehines for planting maize are those whirh deposit the sered one to two inches below the surface in the fine, moist soil, 
and eompant the surface soil over the serel by means of concave wheels about eight inchess wide, while the sparess between the rows are not rompareferl. The matize may be cultivaled and

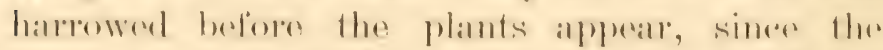
rows may be absily followed hy the marks left by

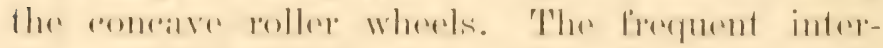
tillage which will be repuirest to destroy werds,

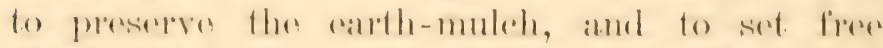
pant-loot, will enmparet the sulsurfare soil quito as much as is desirable.

\section{4c. Potatoes}

2ti2. The potato should be planted deep and

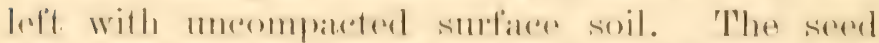
polate antains about .75 per ant of moisture, and has a latrese quantity of stored food for mourishing the buts and smoling up strome shoots. It thrives best in a eool, moist soil: and this eomlition is serement if it is planturl about four inches doep.

Eti:?. It shomld also be mommberend that potat-

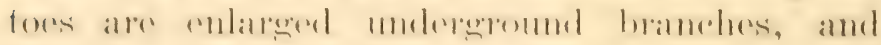

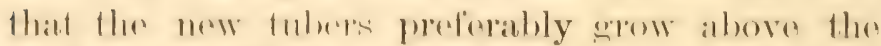
serd-fulder. If the serel-fulne lo planted shallow, the branch ore stem allewe the sered is so

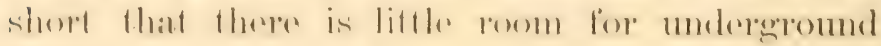
stems.

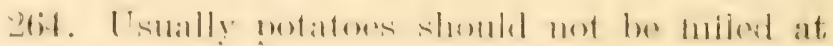




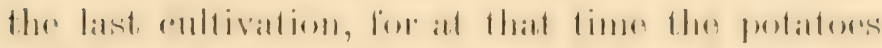

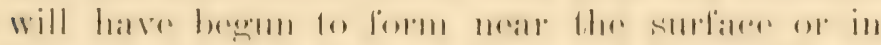

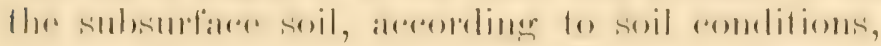

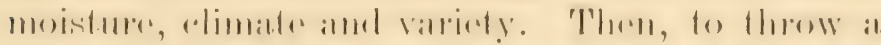

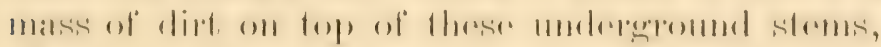

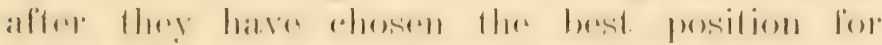

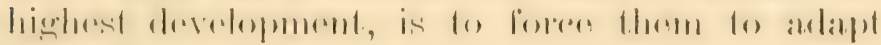
themselves to now romblitions.

\section{SUGGESTGONS ON GHAPTER X}

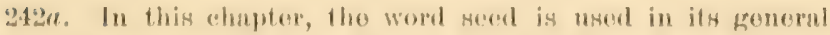

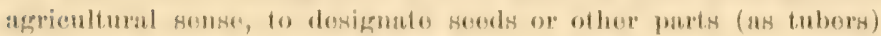
which aro planted for fichla corops.

2.tike. A send-bed is the soil in which the sood in planted or sown. If may bos thes sizo of a window box, a lobbod frame, a ararden bed, of a fiold of wheat.

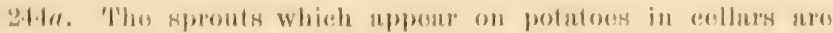

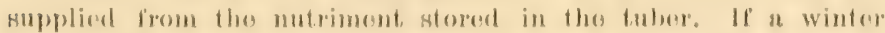
branch of a troes is stoos in wator in as warm room, losteses and somedimes flowess will apposer in the eourso of. a fow wosks ; and the growth is malo from the nutriment stored in the twig. All

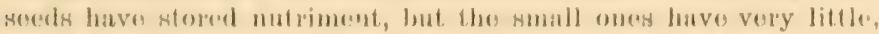
and it may bu exhausted bofore the plantlotes asu grot a foothold in

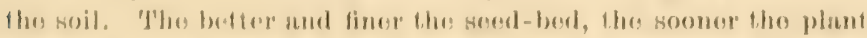
Iot: ean astublish ifsolt.

350er. The subsurfuce soil is that Jying just below tho surfuec, -botween tho surfaces and the subsoll. It is the lower prert of the soil which bas becos loosemed by tho plow, -that patt which is

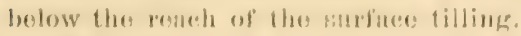

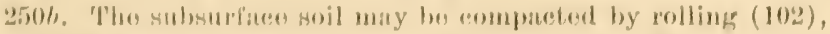
after whish the surfares is foosened by lasrowing. When land is geven much surfues tillagere, an for whest, tho tramping of the

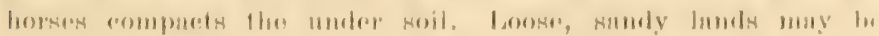

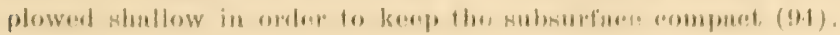




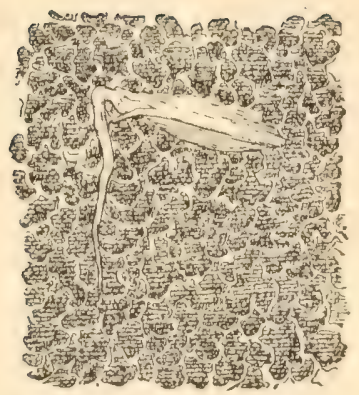

Fig 58. A well drained but moist soil.

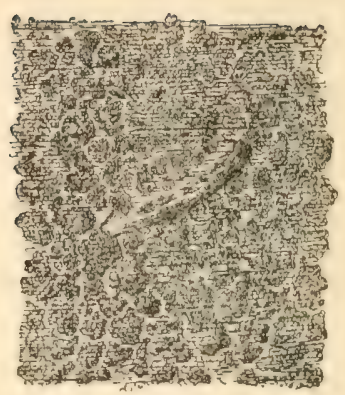

Fig. 54. A wet and uncongenial soil.

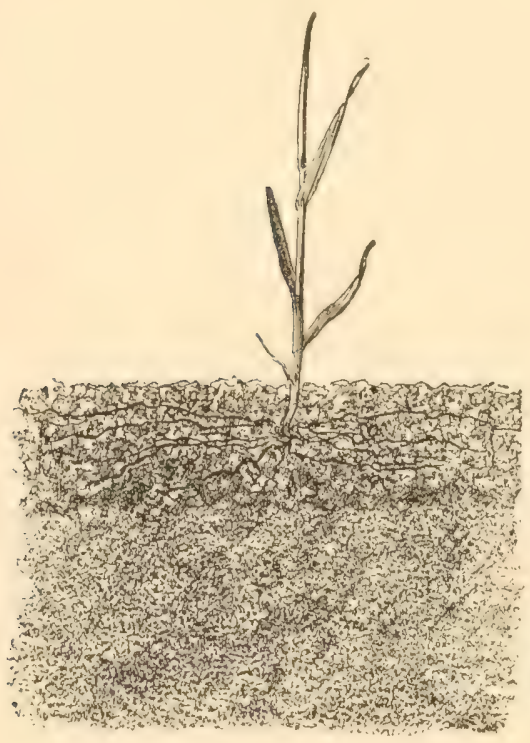

Fig. 60. A wheat plant properly grown, in the fall.

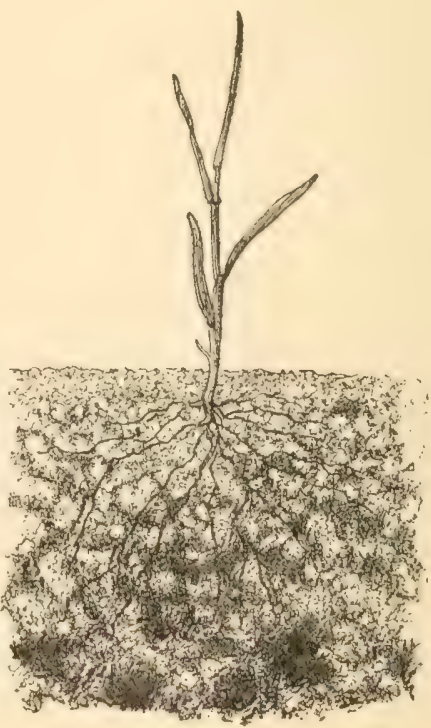

Fig, 61. The result of too loose soil, and manure plowed under. 
251a. 'The Fig. 58 shows a drained soil supplied with moiseure held by eapillarity in the smaller interstices, while the larger channels have been relieved of free water by percolation. Fig. 59 represents a supersaturated soil from which air and heat are largely excluded. If seeds remain for a few days in this undrained soil they fail to germinate, and may rot. Should stagnant water remain in the soil for some time after the plants have appeared above ground, they will turn yellow, and may perish (194). All this emphasizes the necessity of preparing a seed-bed adapted to the wants of the plant to be grown, and of maintaining such soil conditions as are best suited to the wants of the plant during its entire period of growth.

253a. "Care should be exercised not to sow very small and slow-germinating seeds, as celery, carrot, onion, in poorly prepared soil or in land which nakes. With such seeds it is well

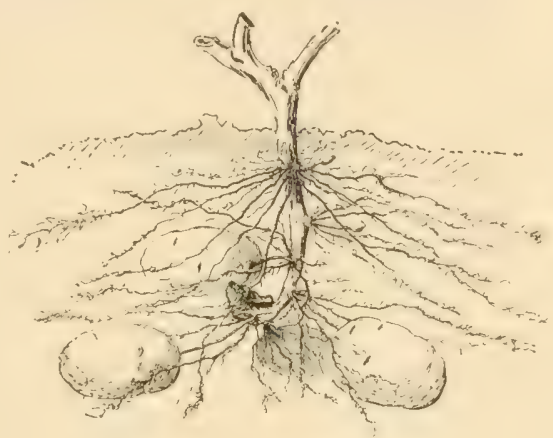

Fig. 62. The itleal eondition.

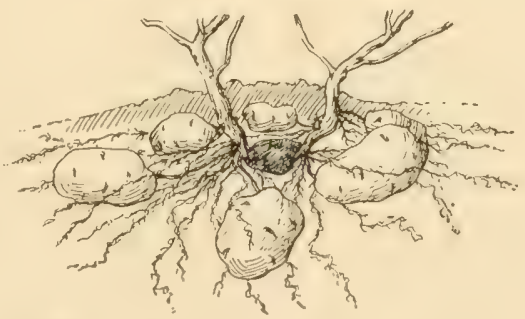

Fig. 63. The result of shallow planting. to sow seeds of radish or turnip, for these germinate quickly and break the crust, and also mark the row, so that tillage may be bogun before the regular-erop seeds are up."-Bailey, Garden-luking, 1 . 37 .

25.) 4 . The expense of preparing the land can often be materially diminished if the lambl is plowerl some little time before it is planted. in such a way that the elements can act upon the soil through the process of weathering. In such eases, the furrow- 
slice is not laid flat, but left at an angle of about forty-five degrees, that the soil may become warmed for the purpose of promoting ehemical action and the liberation of plant-food. It may also serve to hasten the drying of the land (95).

255b. Summer-fallowing is often an advisable means of preparing the seed-bed. It consists of two or more summer plowings and several harrowings, the land remaining idle. Fallowed lands are usually sown to wheat in the fall. An ideal seed-bed can be steured by this means. Fallowing is to be advised when lands are very stony, stumpy, hard, or when they have become foul with had weeds, or have heen injured hy plowing or ditehing when too wet. It is a means of putting the land right. The better the condition of the land,-that is, the better the farming, -the less the necessity of summer-fallowing. The practice is becoming less eommon, landely bucanse modern implements and methods enable us to handle the land hetter.

258a. The pictures will make this reasoning plain. Fig. 60 represents a wheat plant in the fall, on poperly hamdled land. The roots are near the surface. Fig. 61 shows how the roots strike deep when manure is plowed under and the soil is left loose; and this plant stands less chances of success than the other.

263a. 'The accompanying figures, which are made directly from nature, illustrate the point that de epp planting in well-prepared land tends to result in a deep and spreating hill of potatoes (Fig. 62 1, whereas shallow planting in poorly prepared land results. in a shallow and crowded hill (Fig. 63). The better potatoes mar be expected in the former case. 


\section{Chapter XI}

\section{SUBSEQUENT CARE OF THE PLANT}

\section{By Means of Tillage}

\section{1a. In general}

265. Tillage is the first consideration in the care of the plant. This is emphatically true in the field; but in the glass-louse tillage is reduced to a minimum, in part becanse the preparation of the soil is so thorough.

266. The objects of tillage, in the care of the' plant subsequent to seeding or planting, are three: (a) to supply plant-food, by rendering the soil constituents available; $(b)$ to supply moisture; $(c)$ to destroy weeds. The first two captions have been discussed in Chapters ii., iii., iv.

267. (c) Weeds are only incidental difficulties. They are the results of faulty management of the land. If the first attention is given to the crops and the land, the question of weeds will largely take care of itself. It is less important to know the kinds of weeds than it is to know how to till and to crop the land. 
26is. 'Tlase are four general means of kepeping werds in cherek: (a) by good tillage (101, 101a); (b) by rotation of copse, by means of which any one kind of waed is prevented from beroming

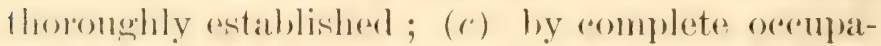
fion of the land with aropse, - for weeds find opfertumity when the gromel is not fully ocempied, as in old and thin mearlows; (d) by killing the weeds directly.

269.) Surface tillage shomld be given as often ats the eround beremes hard, or whenever the

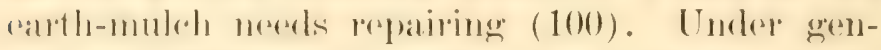
mal conditions, tilled "opos, as maize and potaforse, should be antivated every ten days of two wreks, partirularly rarly in the season. As soom as low cops cover the gromed, and thereby afford it mulch, cultivation may cease.

270). Sowed ropes all often be tilled oncer ol fwice to adrantage rery anly in the season, by rmming a finc-toothed harrow over them. 'Thus, wheat and maize are now often harrowed in early spring. The harrowing destroys but few plants, while it loosens the soil, and conserves moisture hefore murh has been lost by hot weather. Harrowing madows and pastures ranses the plants to tillere or to stool out, and thereby to cover the gromei more rompletely; it also breaks the old, hard roots and causes new feeders to appear, theresty re-invigorating the plants. 


\section{1b. In fruit plantations}

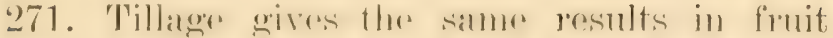
plantatioms as with ammonl romps, and it also las

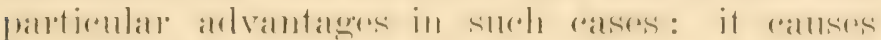

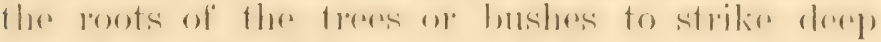
into the soil amd throble to fimd moisture in try

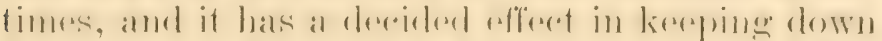

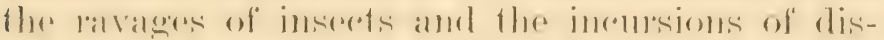
rases hy drestroying hreeding-plaress and horying diseased foliage and fruit.

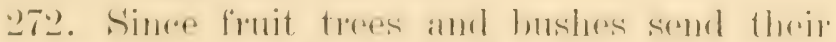

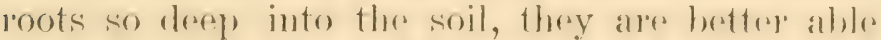

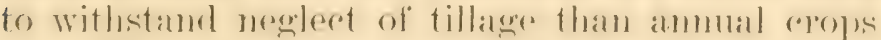

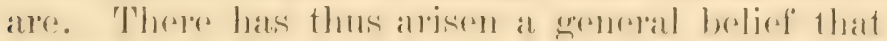

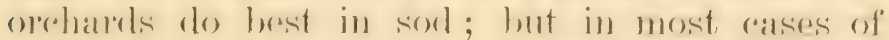

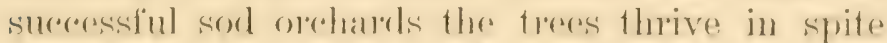
of the sod, not becanse of it.

$27: 3$. It is partirularly important to till fruit. plantations rarly in throp lifo. Apples should gremerally he tillorl for at loast the first tom years.

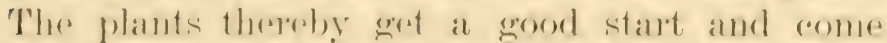

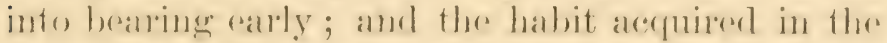
first yours is alst to romtimme. The treatmont

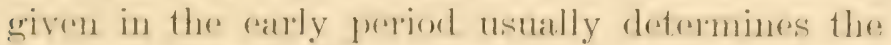
success of the firuit plantation.

274. 'Ther frmit plantation may morel tillage thomethont all the yoals of its rxisterrer, and, as a mattre of fact, it nswally does nerel it. Pat if 
the trees or bushes tend to grow too fast, so that they do not beall, or berome top-heary, or do not stand the winter, they may be ohecked by putting the plantation in sorl; but even then, the sod is only a temporary experdient. If the management of the plantation has been right, it is doubtful if sod an ever be an advantage, -or at least with none of the arommon fruits, except possibly apples and pears.

27.). All fonit plants start into growth very early in the season. 'Therefore, tillage should be begme the monent the ground is fit; and it should be contimued unremittingly until the time arrives for all tillage to cease.

276. The growth on fruit plants generally ceases by midsummer. Therefore, tillage may stop at midseason or early fall ; and at the last tillage a cover-("rop may be sown (109), 114, 116). Stopping the tillage arrly allows the plants to mature their gros.th, and thereny be more likely to escape winter injury ; and it lessems the danger of overemowth. If the treas are anrying a heavy "rop, howevere, it may be necossary to continue the tillage in order to supply the fruit with moisture, especially if the land or the season is dry.

277. The tillage of fruit-plautations usually consists of a spring plowing, followed by harrowing. If the land has been well handled in 
the first few years, deep and heary plowing will not be needed when an orehard eomes to matturity. Light gang-plows, or "ven rultivators, may then be sufficient for the first breaking of the soil in spring.

\section{¿. B!y Means of I'runing and Training}

2a. Pruning vs, training

278. Pruning is the removing of certain parts of plants for the purpose of alugmenting the welfare of the plant or to serme more, latrere or better products (as better fruit or flowers). Training is the trimming or shaping of the plant into some particular or desired form. Sucressful pruning depends upon principles of plant growth; training depends mon the personal ideal of the pruner.

279. Nature prumes. In exery plant, nower branchess start than can ever mature; and many buds are suppressed befores they have make

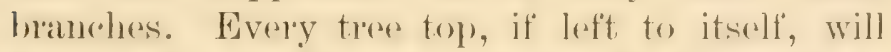
sooner or later contain many dead branches. There is a strugerlo for existences annongst the branches, and the weakest die.

\section{2b. The healing of wounds}

grat). Pruning depends upon two sets of factor's, - unon the questions concerned in the heal- 
ing of wommds and the injury to the plant, and upon the general results which it is desired to allain. Knowing how wounds affect the platnt, the promor should then have a definite purpose in viow when ho outs a limb.

ss1. 'The proper healing of wommes depends jeimarily upon (a) the kind of plant (observe that peach trees heal less readily than apples), (b) the vigor of the plant, (c) the position of the wound on the plant (wommds on stroms main limbs heal better than those on weak of sides limbs), (d) the leneth of the stump-the shorter the stump the quicker the healinger,-(e) the character of the wound as to smoothmess or roughness.

¿g.2. Other matters which determine tho propere healing of a large wound are $(f)$ the hrallhlulness of the wood, (g) the season of the your in whinh llow ent is made, (l) the protection which the womnd receives.

s8.;. (g) Other things being the same, wounds hoal quireker when made in the carly part of the

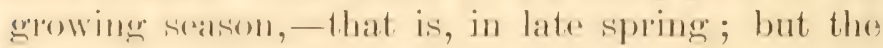
lactors montiones in est are mole important than the season.

gst. (11) Drosings do not, of themselves, hasten the habling of womnds, but they may kerel 1he monmel somml and healthy motil it heals ol itsell. I gomel dressing is one which is anti- 
septic and durable, which affords merhanical protection, and which dors not of itself injure the tissue of the plant.

\section{2c. The principles of pruning}

285. We prume (a) to monlify the viener of the plant, (b) to problue largere and better fruits or flowers, (c) to kerep the plant within manatger able shape and limits, (d) to make the plant bear mome or bear lessis, (a) to remove sipurefluous or injured parts, (f $f^{\prime}$ do facilitatr spraying and harvestinge, (g) to laceilitate tillager, (h) to make the plant assume some dexired form (properly, training).

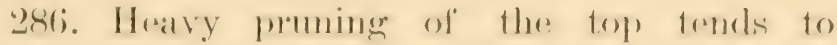

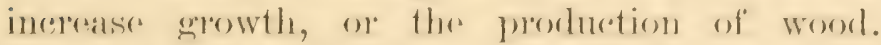

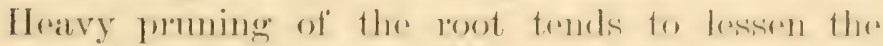
produretion of wood. Watre-spronts eremerally follow hrasy proming, partirularly if the pruning: is performed in winter.

287. Chereking erowth, so longe as the plant remains healthy, formls to rause overemown plants to bear. One merens of relereking gerowth is to

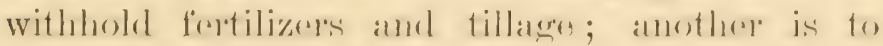
resort to root-proming ; anothere is to hearl-in or cut-back the yomeres shoots. Somme plants, howover, hear most polusely when they are very vigoroms; lut they are surele, for the most pald,

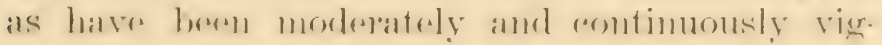




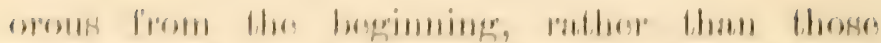

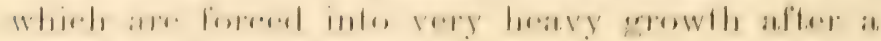
loner parrionl of martand.

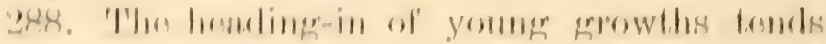

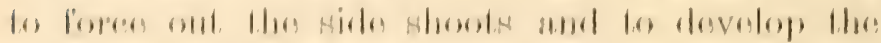

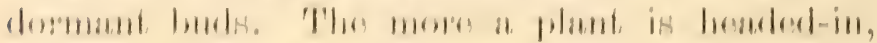

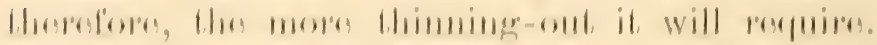

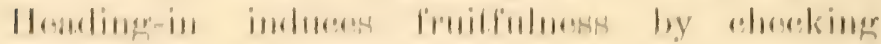

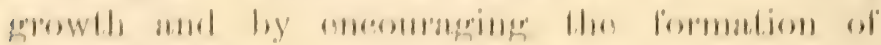

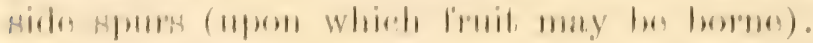

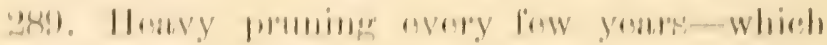

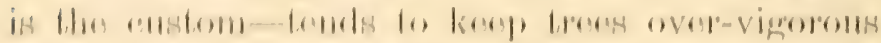

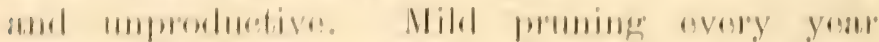

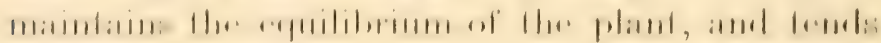
lo malou it limilnal.

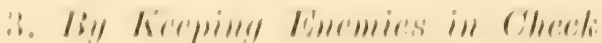

ine Ther lindes of rememias

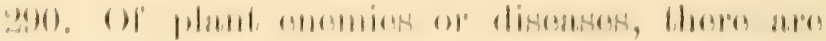

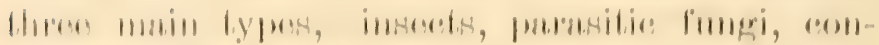

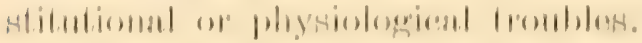

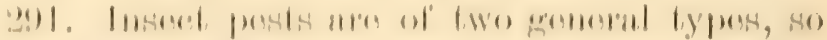

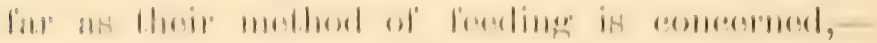

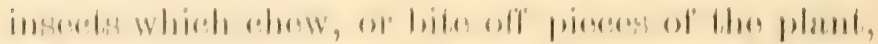

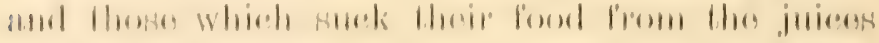

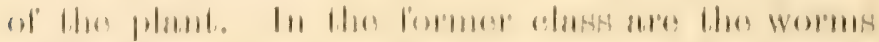

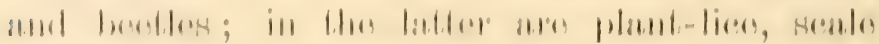

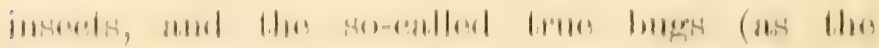




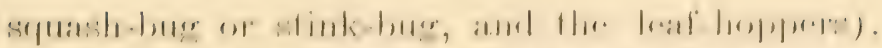

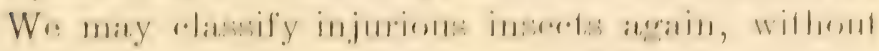

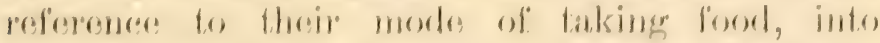

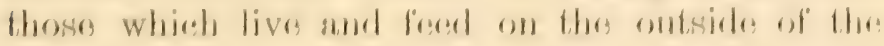
phast, and thoses which, as foroses and apploworms, burrow and fosed insides llere tissise.

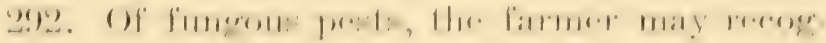

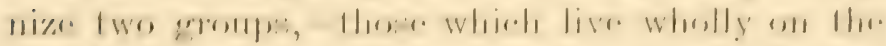

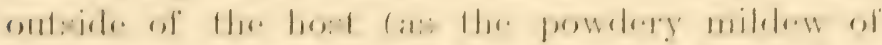
the grapes, proa mildow), and thoses which live wholly or in part insides thos tissurse (as mplob-

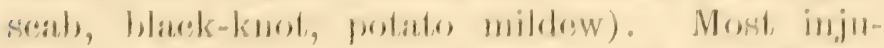

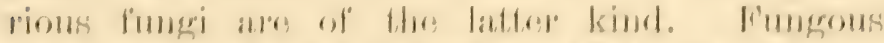

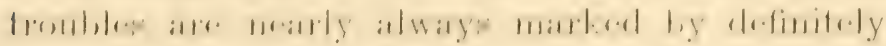

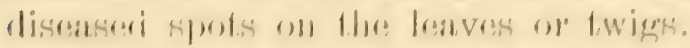

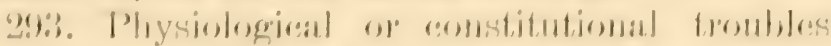

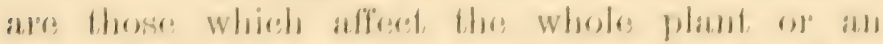

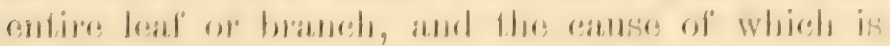

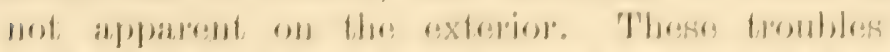

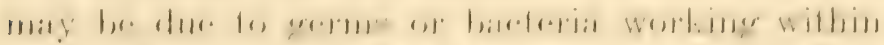

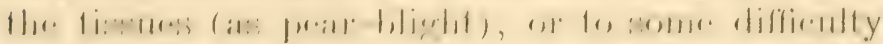

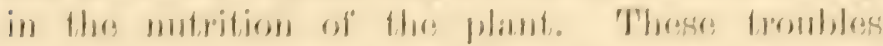

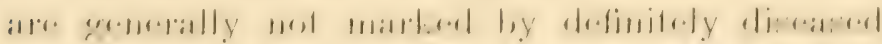

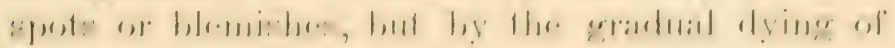

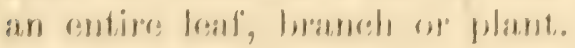

\section{The preventioes and remedies}

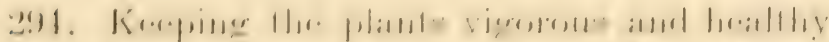

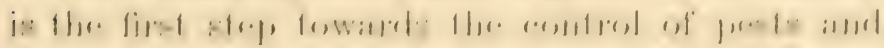


diseases. Clean tillage, rotation of crops, planting varieties which are least liable to attack, and careful attention to prevent all the conditions which seem to favor the breeding of insects and the spread of diseases, are quite as important as destroying the enemies; for "an ounce of prevention is worth a pound of cure."

295. Insects are destroyed by three general means: (a) by killing them directly, as by handpicking, digging out borers; (b) by killing them by means of some caustic aplication to their bodies; (c) hy poisoning them by poisoning their foor. In some instances, insects may be kept away by covering the plants with some material, as lime, to which the insects object; but this method of fighting insects is usmally unsatisfactory. A substance which is used to destroy an insect is called an insecticide.

296. (b) The caustic applications or insecticides must be used for those inserts which suck their food (291). Kerosene, kerosene emulsion, soap washes, lime-and-sulfur, miscible oils, tobaceo, and the like, are the materials used; and plant-lice, scale insects, plant-lugs, thrips, and leaf-hoppers are the insects thus treated.

297. (c) The poisonous applications are used for the chewing insects that prey upon the outsicle of the plant (not for horers, which are usually (lug out). Paris green and other arsenicals 
and white hellebore are the materials commonly used ; and worms, potato-bugs, and all leafchewing pests, are the insects thus treated.

298. Fungi are killed by materials which contain sulfur or eopper. Fungi which live inside the leaf or stem (을 by applications, but the parts which project into the air (the fruiting portions) ean be destroyed and the fungus therely weakened and checked; and the spores (which answer to seeds) cammot grow on a surface which is covered with ropper or sulfur. The best treatment of plant diseases, therefore, is to make the application before the disease gains a footholel. A substance which is used to destroy fungi is alled a fungicide.

299. The best general fungicide is the Bn:deanx mixture, made of lime and sulfate of copper. It not only destroys the fumgi, but adheres long to the plant. Another good fungicide is carbonate of copper ; and it is preferred for ornamental plants and for late application to fruit, because it does not discolor or soil the leaves or fruits.

300 . The application of insecticides and fungicides is usually made in water, with a syringe or pump, or by means of a spray; and thereny has arisen the practice of spraying.

301. In order that spraying shall be successful, it must (a) apply the materials which will 
destroy the pest in question and yet not injure the plant, (b) be thoroughly done, so that no part of the plant is left murrotected, $(c)$ be performed the moment the enemy appears, or, in the case of fungous diseases, as soon as there is reason to believe that the pest is roming.

302. 'The best machine or prump is the one which throws the finest spray the farthest distance. Other faretors are the capacity of the pump, its strength, its durability, its lightness, the ease with which it works.

303. Spraying will not keep all fungous diseases in check; and, in any case, it should be supplemented by sanitation, as by hurning or burying the fallen diseased leaves and fruits, the cutting away of infected parts, and the like. Some fungous diseases, as the grain smuts, are carried over from year to year in the seed; and the proper treatment is to soak the seed in a fungicine. The ronstitutional diseases (29:3) must be treated by other means than spraying, usmally by burning the affected part or plant $(294,294 a)$.

\section{SUGGESTIONS ON CHAPTER XI}

267a. "The daisy-cursed meadows of the East are those whicb have been long mown and are badly 'run,' or else those which were not properly made, and the grass obtained but a poor start. The farmer may say that the daisies have 'run out' 
the grass, but the fitct is that the meadow began to fail, and the daisies quickly seized upon the opportunity to gain a foothold. * * * The weedy lawns are those which have a thin turf, and the best treatment is to serateh the ground lightly with an iron-toothed rake, apply fertilizer, and sow more seed." "The agricultural conditions in the Dakotas and other parts of our Plains region are just such as to encourage a hardy intruder like the Russian thistle. An average of eight or nine hushels of wheat per acre is itself proof of superficial farming;

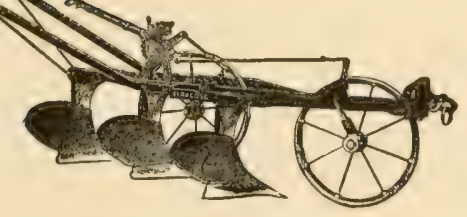

Fig. 64. A gang-plow.

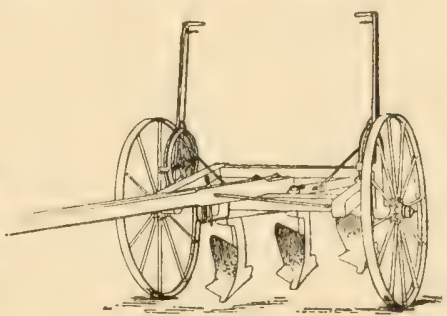

Fig. 65. A light gang-plow for very shallow work.

but the ehief fault with this western agriculture is the continuous eropping with one crop, - wheat."-Bailey, "Surviral of the Unlike," pp. 196, 195.

270a. Maize may be harrowed until it is four inches high. The plants will straighten 1p. 'This harrowing is cheaper than cultivating; and if the land is put in good condition very early in the life of the crop, much less subsequent tillage is required. In general, narrow-toothed harrows should be used (Fig. 24), but the style of tool must be adkpted to the particular land in question.

$277 a$. If the plowing has been thorough for the first few years after the orchard is planted, the ground should be so mellow that very light plowing will answer thereafter. There will be no sod to tear up and to plow under, and the tree roots will he leep in the ground, where they ean find moisture. A gang-plow (Fig. 64) should he suffecient for the spring plowing 


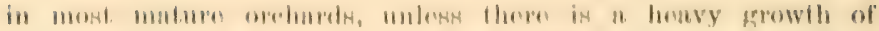

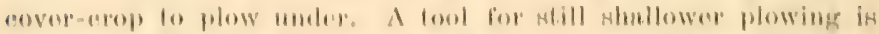

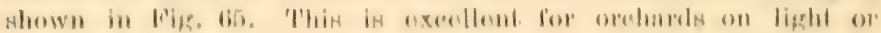

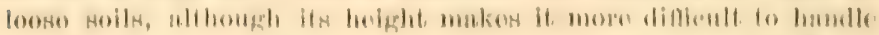

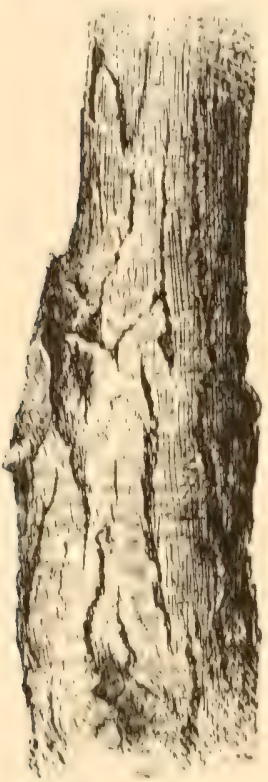

Wist tit. The molur way to make the sersant.

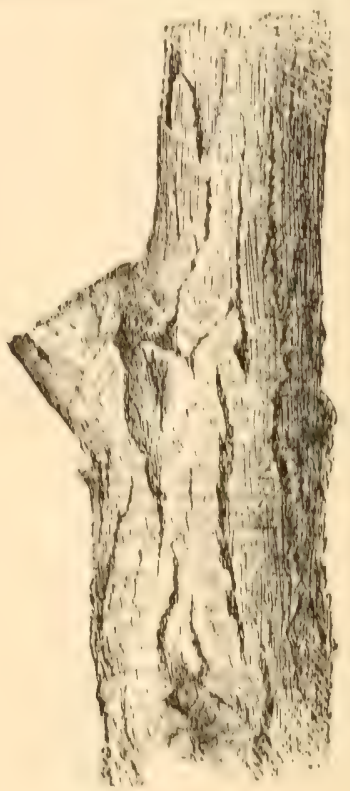

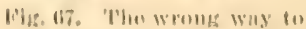
muke the sout.

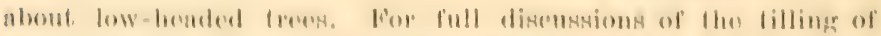

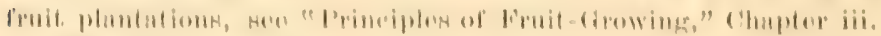

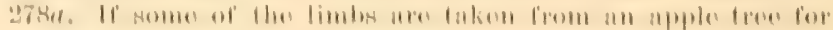

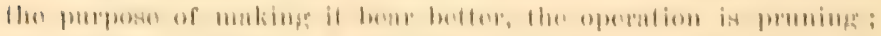

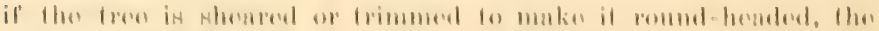

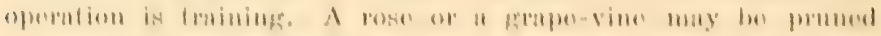

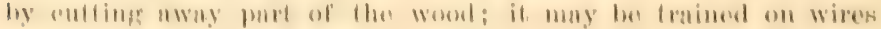
of 


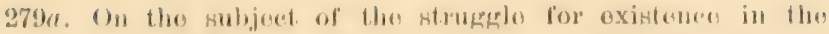
troo top, eonsult, Observalion iv. in "Lassons with P'lants," and

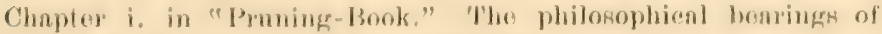
this fact of competition stre presented in Jissay jii., "Survival of tho Unlike."

"281a. ()ther things boing ofunt, the eloser the wombel to the branch, the quickere it will honl. Tho smoother the womel, the better and quicker it will loas. J'igse. 66 and 67 illustrate right and wrong mothorls. lor full disenssion of the heuling of. wounds, rend Chaptex iii. in tho "fruning-Book,"

"284a. An antiseptic drossing is one which prevents germs or microbos from growing on thes surface of the wound; for the decery which follows wounds is tho work of grorms and fungi. In genoral, tho best drossing for wounds is lead paint. Wax is not durable onough, nor is it antiseptic. Bordosux mixture

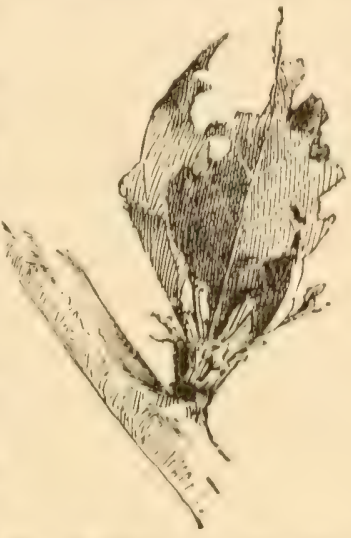

rige. 188. Work of' the bud-moth Itrva, - th ehowing insoet. is rood for its antisoptic propertios, but is not durable, and it affords liflo protertion from tho weather.

285a. 'I'ho minciples of pruning aro discussod mondor twonty hesuls in Chaptor iv. of. "Pruning-130ok."

a)la. 'Lhe chewing or biting insects ont up the parts upon which thoy proy. Jig. 68 is an exmmple of such work, 'I'ho sucking insecels do not oat up tho piat, but they often loavo distinct marks of thoir work, sts in lig. 69. A plant-bug is shown in Fig. 70. 'Tho true weovils and oureulios fro biting insects, although thoy have suouts (lig. 71).

292a. $\Lambda$ fungus is a phunt. It is destitute of chlorophyll or leaf-greon. It lives on living orgmisms (or is partsitic), or on doat or docalying mattor (or is silprophytic, as mushrooms nut toadstools). Somo kinds, an toadstools, stro latgo and conspicuous; others, as molels, sro small and fragile; whilo still

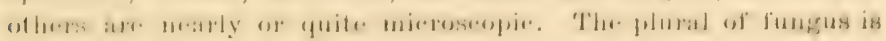


fungi (raroly written funguses). As an adjective, the word is written fungous, as a fungous disease. A fungoid disease is a fungus-like disease, the "xart origrin of which may not he known or speceified. Rusts, mildews and leaf-blights are types of fungous diseases.

293b. 'The plant or the animal upon or in which a parasitic fumgus lives is known as its host. The fungus injures its host by

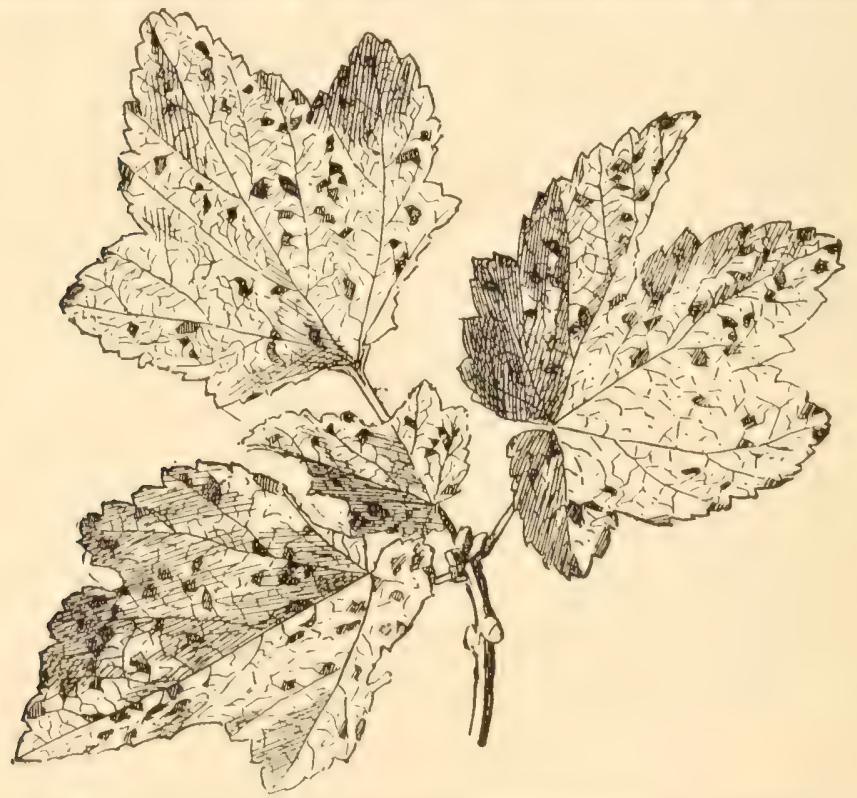

Fig. 69. Work of the four-lined leaf-bug-a sucking insect-on currant toliage.

rolbing it of mutriment and sometimes by breaking up its collular structure, and by olstrueting the lowathing-pores and interfering with the movement of its fluids.

293\%. Physiological trombles may be termed internal troubles, ulthough the germs which cause some of them enter from the 
outsile. There is no external growth of a fumcus, and rately any well defined small spots on the leaves. Fign. 72 shows 1 he spots of

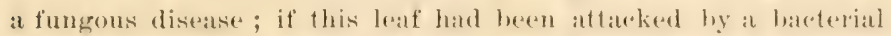
or physiologiral disease, the entire leaf would probably have shown sigms of faling, for the food supply is usmally rout off in the leat-stalk of the main veins. In Fin. 72, lowever, eilch spot represents a distinct attack of the fungus. Fig. 73 is a type of physiologial trouble, the edge of the leaf dying from the entting-off of its food supply; this dead border will widen until the leaf dies.

294a. Physicians treat some diseases by prophylaxis, - that is, by giving attention to means of sanitation and of preventing the spread of the disorder. Farmers must do the same. Wire-worms are rarely troublesome in short and quick rotations, particularly in those in which sod is not a prominent feature. Club-root of the cabbage is rarely troublesome on land which has not grown cabbages or allied plants for a few years. Apple-seat) is least serious in thoset orelards which fave been thoroughly sprayed in previous years. Plum-rot is least troublesomo

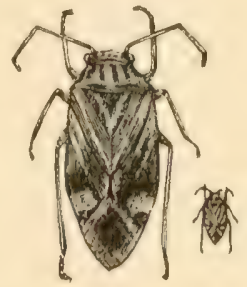

Fig. 70, The tarnished plant-bug, - a sucking insect.

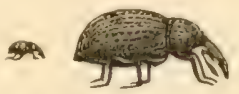

Fir. 71. The strawherry wervil, - a chewing insect.

when the frut is well thimed. Rose-hugs seldom troublo vineyards which are on strong or heavy lands.

296a. Kerosene emulsion may be mate ats follows: Hard, soft or whale-oil soap, $2 / 2$ lb.; water, 1 gal.; kerosene, 2 gals. Dissolve the soal, in hot water; remove from the fire and while still hot add the kerosene. P'ump the liquid back into itself for five or ten minutes or until it becomes a creamy mass. If properly made, the oil will not separate out on cooling. For use on dormant trees, dilute with from 5 to 7 parts of water. For killing plant-lices on foliage, dilute with 10 to 15 parts water.

crute oil emulsion is made in the same way hy substitutiug crude oil in place of kerosene. 
297 . The Paris green mixture is eomprounded by using Paris green 1 pound, water 150 to 300 gallons. If this mixture is to he used uprn fruit trees, 1 pound of quicklime should be added. Repeated applications will injure most foliage, unless the lime is used. Paris green may be added to Bordeaux mixture.

29) Th. Arsente of lead is now much used for chewing insects. This can be applied in a stronger mixture than other arsenical

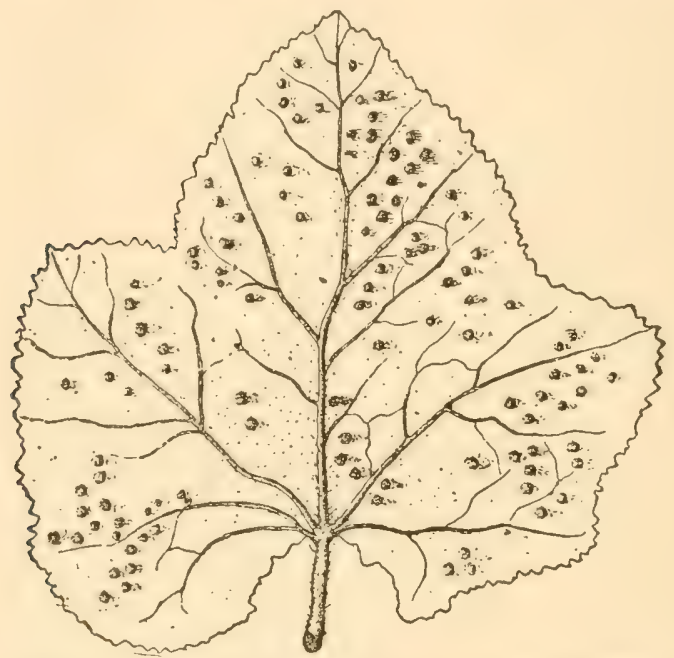

Fig. 72. The spots of hollyhock rust, - a fungous disease.

poisons without injuring the foliage. It is, therefore, much used against beetles and other insects that are hard to poison. It comes in the form of a paste and should be mixed thoroughly with a small amount of water before placing in the sprayer, else the nozzle will elog. It is used in strengths varying from 4 to $10 \mathrm{lbs}$. per 100 gallons, depending on the kind of insect to be killed. Arsenate of lead and Bordeaux mixture ean be combined without lessening the value of either.

297c. The lime-and-sulfur wash, for scale insects, is now 
much nsed: Quicklime, $20 \mathrm{lbs}$; sulfur (flour or flowers), $15 \mathrm{lhs}$; water, 50 gals. Place the lime in a kettle. Add hot water gradwally in sufficient quantity to produce the most rapid slaking of the lime. When the lime begins to slake, add the sulfur and stir together. If convenient, keep the mixture covered with burlap to save the heat. After slaking has ceased, add more water and boil the mixture one hour. As the sulfur goes into solution, a rich orange-red or dark green color will appear. After boiling sufficiently, add water to the required amount and strain into the spray tank. The wash is most effective when applied warm. This mixture can be applied safely only when the trees are dormant, - late in the autumn after the leaves have fallen, or early in the spring before Fig. 73. Disease of cucumber leat, the dying the buds swell.

299a. Bordeaux mixture

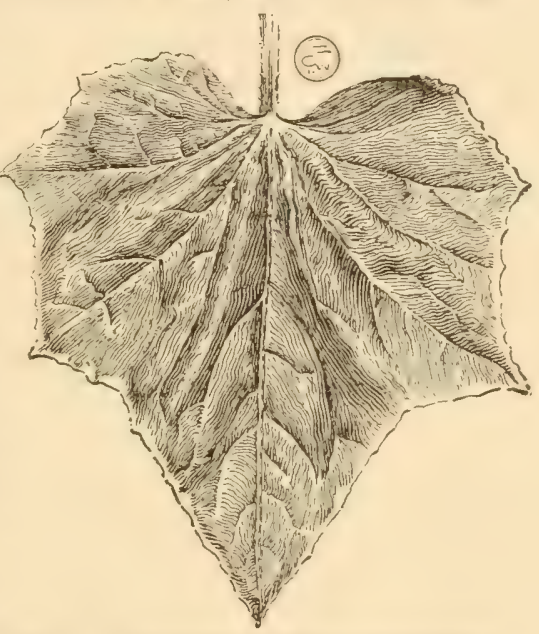
margin indicating that the trouble is due to some cutting-off of the food supply. is the standard fungicide. It is made of copper sulfate, $5 \mathrm{lbs}$.; stone lime or quicklime (unslaked), 5 lhs.; water, 50 gals. The strength varies according to the plant to be sprayed. Bordeanx may be prepared in the following way:

Conprer sulfate.-Dissolve the required amount of copper sulfate in water in the proportion of one pound to one gallon several hours betore the solution is needed; suspend the copprer sulfate crystals in a sack near the top of the water. In case large quantites of stock solution are neerled, two pounds of copper sulfate may be dissolvea in one gallon of water. Lime.- Slake the lime in a tub or trough. Add the water slowly at first, so that the lime crumbles into a fine powder. If small quantities of lime are used, 
hot water is preferred When completely slaked, or entirely powderen, ardd more water. When the lime has slaked sufficiently, add water to bring it to a thick milk, or to a certain number of gallons. The amount required for each tank of spray mixture can be secured approximately from this stom mixtme, which should not be allowed to dry out. To make Bordenur.-Use 5 gallons of stock solution of copper sulfate for every filty gallons of Bordeaux required. Pour this into the tank. Adl water until the tank is about two-thirds full. From the stock lime mixture take the reruired amomnt. Dilute this a little by adding water, and strain into the tank. Stir the mixture, and add water to make the required amount. It is preferable to dilute the copper sulfate solution. Never pour together the strong stock mixtures and dilute afterward. The fermeyanite test. - It is not necessary to weigh the lime in making Bordeaux, for a test call be used to determine when enough of a stoek lime mixture has been added. Dissolve an ounce of yellow prussiate of potash in a pint of water. Add the lime mixture to the diluted copper sulfate solution until the ferrocyanide solution will not turn brown when dropped from the bottle into the mixture. It is best to add an excess of lime.

2996. Copper carbonate is used as follows: Copper carbonate, 1 ounce; ammonia, enough to dissolve the copper; water, 9 gallons. Before making the solution, make a paste of the copper carbonate by mixing it with a little water. Ise $26^{\circ}$ ammonia, and dilute with 7 to 8 volumes of water. Then gradually ald the necessary amount to the copper "arbonate until all is dissolved. Use only the clear liquid. Diinte as required. For same purposes as Borleaux, but does not soil foliage or fruit.

303a. Smut-infested seeds are treated hy corrosive sublimate, formalin, copper sulfate, hot water, and other means. For the first, use corrosive sublimate, 1 , oz.; water, 7 gals. It is an effective solution for potato seab. Soak seed potatoes $1 \frac{1}{2}$ hours.

Formalin is a gas dissolved in water. Commercially, it has a strength of ahout forty per cent. One pint dissolved in thirty gallons of water is used effectively in preventing potato seab (soak tuher's for half an hour, and plant in elean snil), or smut of oats and stinking smut of wheat (swak seed in solution for ten minutes, drain and sow the next day). 


\section{Chapter XII}

\section{PASTURES, MEADOWS, AND FORAGE}

\section{P. ROBERTS}

\section{Grass}

304. The fundamental erop is grass. It covers the land as with a blanket, prepares the soil for other crops, and affords sustenance for farm animals.

30.5. Grass is one of the important ('rops in rotations; and a rotation is essential to general husbandry if productiveness of the land is maintainerl. Rotations imporove the fam (a) because the land receives different treatments in different years, so that faults of one year may be corsrected the following year, (b) no one element of plant-food is likely to be exhansted, (c) one erop leaves the land in lest condition tol another, $(d)$ roots and stuble of grass, chovel and cereals improve the texture of the soil, (e) they allow the use of clovers, which add nitrogen, and $\left(f^{\prime}\right)$ bring up food from the subsoil $(170,170 a)$, (y) werts and pests are kept in check, $(h)$ labor is economized. 
306. The number of plants of grass on a given area should be governed by the uses for which they are grown, their habits of growth and their size. 'The smaller crasses thrive well if the plants stand near togrether. 'The Iarger' grasses, as maize, should have much room botwern the plants or hills. The plants in a pasture fied shonld be more mumerous than in the mearlow, and more numerons in the meadow than in fields devoted to raising grass seed.

\section{Permanent Pastures}

\section{2a. Preparation of the land}

307. When the land is fairly level and can be fitted without too much expense, it is best to plow the ground two or there times during the summer, the first time in arly spring, and to keep the surface fine and rean by frequent tillage. This treatment improves the physical condition of the soil, destroys weeds and weed seeds, makes much domant plant-food arailable, and ronserves moisture so that the surface soil, in most cases, will he damp enough to cause seeds to germinate even in August.

308. ()n frialule soils, as on the western pravies and in some ofler places, a single plowmg and freduent shallow surface tillage may be 
the best treatment. On reclaimed boggry lands which have been enltivaterl long enough to eradirate wild plants, the soil is so light that plowing may be mmeessing. Here a little scarifying of the surfare and freruent use of the roller will likely give best results.

309. A good pasture may also be secured by less expensive preparation, if more time is taken. When rolling land has been devoted to the production of cereals and hay until the soil fails to produce satisfactory crops, it is often wise to abandon the unprofitable rotation and to devote the land to permanent pasturage; but few persons are willing to spend as much time and money as will be necessilly to secure a good pasture at once. In that ease, sow a liberal ruantity of pasture seerls in a rrop of thinly seerled wheat, rye, barley or buckwheat, the land having been fitterl for the cereals with extra care, and plant-food added by a liheral application of fertilizers or manure.

310. Since the pasture is not to be plowed after it is once seerlerl, it is necessiary to prepare the entire soil so perfectly that it will form a comfortable home and provide nomishment for the plants for many years. If the land is poor, fertility should be anplied. But prepares the land as hest wo may, it will not be many years before much of the reartily availahle plant-fond 
will have heen used hy the plants, and some of the products of the animals which consume the grass will never be returned to the pasture; hence, the pastule will tend to become less productive as the years pass. And, as the plants become old, they are less vigorous than young ones, not only becanse of age, hut from frequent injuries from the animals. It is, therefore, necessary to maintain the pasture, as woll as to prepare it in the beginning.

\section{2b. Maintaining the pasture}

311. The grass should he of the right kind. In the North, Jume-grass or blue-grass is the most pelmanent pastule grass, and it is the one which gradually works into pastures after other grasses begin to fail. 'Timothy is commouly sown, about six quarts to the acre. A little June-grass seerl may he added, but this grass may usually he repended mpon to come in of itself. Orchardgrass is useful in shady pastures and stands grazing well, but grows too much in stools. Red-top is useful in the moister lands. In the South, Bepmula grass amel Japan cover are best.

31:. After the jastures has been secomed, the grasses must he maintained for many years in full vigor. It is low-sulposed that the clovers ha:r hesen nsed to a limited extent in the grassseml mixtures when the jastin\% was first made, 
since the clovers are host plants to the grasiose They start early and protect the later-growing grasses. Most of the clovers live but from one to three years. The clovers, in common with other legumes, contain a large percentage of potential nitrogen $(110,138,190)$. The pasture grasses are much benefiter by a full supply of nitrogen, but they can secure little, if any, from the air, and hence must supply their needs as best they can from that found in the soil. It will then be understood how eagerly the hungry grasses feed on the decaying short-lived clovers. It will also be understood why clovers are called host plants.

313. The short-lived host plants may be perpetuated, and the grasses kept young and rigorous, by sowing seeds of the clovers and grasses every two or three years in early spring, and searifying the surface with a sharp-tonthed harrow, this to be followed by the roller. The harrowing will not only tear out some of the superammuter grass ronts (270) and old plants and cover the seeds, but it will tend to aërate the surface soil and to promote bacterial activity. From time to time, a light dressing of farm manures or of rommereral fertilizers should be applied, spread evenly, in the fall.

314. An inspection of the field should be marle each spring, in orden that seed may be 
som where not enough plants are present, and also to discover what kinds of plants are most promising, so that the supplementary secdis may be chosen to hest suit the conditions. Coax the grass to grow ly shading the imperfectly corered knolls with refuse material, such as is always found about a famstead. Eren a light covering of brush or maize stalks may be used to partly shade the ground, and to conserve moisture. If a small ration of grain be fed the animals which waze the pasture, the field will tend to become more profluctive instead of less productive.

315. It will require several years of watchful care, new seed, possibly harrowing and rolling, some added plant-food and a light dressing of lime, and the timely destruction of large, unpalatable weerls, to secure a really good, permanent pasture. The eye of the husbandman makes the grass thrive.

316. In the pastures the grass is kept short; therefore the entire surface should be covered. If areas of even a few square inches are hale, needless evaporation takes plact. If the grasses are kept too short, the lays of the sin will take up much soil moisture which should have heen taken up by the plants. since the soil will not he well shaded. If the plauts are allowed to grow tall and probluce serel, then they are 
weakened. To prevent the tall growth, mow the pasture, if there are not enough animals to prevent the grass from seeding, and leave the rut material to shade the soil. Aim to preserve the living grass shade intact. Substitute young plants for the old ones. Prevent the soil from becoming acid by light applications of lime and by harrowing it. And, so far as possible, exercise timely care to prevent the plants from becoming hungry and thirsty.

317. Here, then, in a nut-shell, are the elements of a good, permanent pasture: superior preparation of soil, suitable and abundant seeds sown in August, and light pasturing the first season, or, better, mowing the first year; and appropriate seeds and plant-food must be added from time to time, as required.

\section{Meadows}

\section{3a. Temporary meadows}

318. In grain-growing rlistricts, the meadow may occupy from one to three years in a rotation. In dairy districts, meadows are often permanent. The average yield of hay in the North is little more than one ton per acre, although some meartows rield from two to three toms, and, in rale rases, fom tous. The averager 
rield is muprofitable, either in a rotation or in a permanent meadow. As a crop in the rotation, the meadow may improve the soil for subsequent crops.

319. The larger vields are usually secured from vigorous young meadows which rontain thres or four parts of timothy and one part of mixed coloreps. If roper be assoreiated with timothy in aproximately these proportions, nearly as much timothy will bes serured as if it were sown alone, and the rover, or host plants, will be extra. True, the clovers mature more quickly than the timothy, and this is somewhat objectionahle; therefore, the clover mixture may he composed largely of alsike clorel', which remains green longer and "ures lighter coloperl than the merlium red rovel does.

:320. The mearlow must be viewed from many stanclpoints. For the eity market, mmixed hay sells for moles than the maxed, though the latter may be better and more palatable. The uses to which the hay is destined must he eonsidered, since horses shoukl not he ferl much rover, while sheep and rattle should not he fed hay composed wholly of timothy and similar grasses. But the mearlow remains productive longest where the host plants are present.

:321. Whether it is best to leare the mealow for some rats and meserve its productiveness 
by athing new soesl, harpowing, and by the application of plant-ford, or to mow it for one or two years and then plow and use the land for other crops, are questions which must be answered by the romdition of the mearlow and the rharactere of the potation. There is one invariable rule to he followerl, - if the mearlow fails to return two toms of fiesle-dried hay to the acre, plow it up; and when the old plants are subchere and the soil put in irleal eondition, and when the causes which prevented full suresess with the old mearlow are fully consirlered, cast in the new seerl with understanding, trusting that fuller success will be reached.

\section{3b. Permanent meadows}

322. With permanent meadows many new problems are presented. Many fields are of such a character as to preclude a rotation of crops. In such rases the problem is presented of contimned liberal production withont plowing. Low lands, or those which are wholly or in part overflowed for brief periods, constitute the larger part of our permanent meadows. These low lands are the home of many natural grasses which do not thrive on the mplands; and some of the rultivated mpland grasises and the relovers are not at their hest when erown in wettish soils. 
3:3. In lowland meadows, a hattle royal, which is most interesting and instructive to wateh, groes on from yeall to year. Most of the plants hold their placess so temareionsly, and so many hardy new ones appeall, that the plants soon bereme too numerous and then flwate one another, in which rases the prochetion is diminished. (On these moist lames there is little diffienlty in securing sufficient plants: the problem is rather how to destroy some of them, that better eonditions may be sereured for those which remain.

324 . It has been shown (:316) why the pastures should be fully eovered with plants; but permanent meadows should have fewer plants. If there are too many, the glasses will not grow to their full size, and many of the leares on the lower half of the stalks will be yellowish, insipict, and lacking in aroma berallse they hate not received enongh sumlight. If there alle tox many roots in the soil, there will not be suffiedent forml for all except when the soil is extremely fertile and moist : and tew plants will eome to normal maturity. The grassess which ale grown tor thick, and conseapuently have been exeluded from a full sulply of sunlight, are poor in quality, like the apples which erow in the shate on the lower branches.

325. All this goes to show hom necessary it 
may be to drestersy somes of the grasses in a bermanent maarlow. By thr vigerous use of a shatp-toothed labrese, mureh may bes dones to

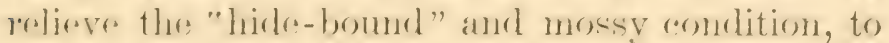
dretroy plants and to ä̈rate the soil (207(), :31:3). 1 lisht drossing of lime will matrolally assist in librrating plant-forol and in correcting soil acidity, as in pastures.

\section{3c. Kinds of grasses for meadows}

326. What kind and quantity of searl should los sown, is the question that is askerl mones frempuently than any othere, heseanse it is most liffirolt to answer. In the grass districets of thr. [nitre] Sitates, timothy or "hemel's-grass" usually" stands first. It is retromely lamely, lomg livert, is

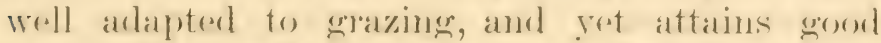
sizr in the moarlow, and when rout at the apporo-

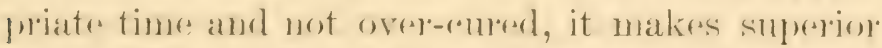

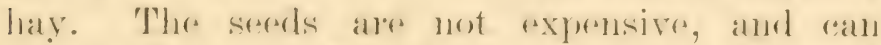

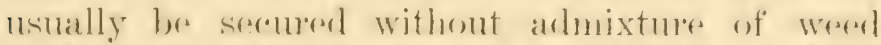
sereds. Timothy, thren, in most rasere, may form

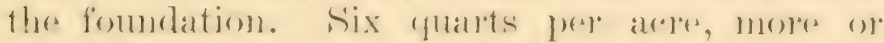
less, will suffico whrom nserel alomer, and it may hes sown at any time form waly spring until fall.

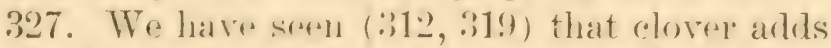
to the lonorevity and prorluctiveness of the pastrive or incarlow. If the colovers are used, about 
the same amount ol a little more seed is sown as of timothy, lut the plants are likely to be winterkilled if sowing is made after Angust.

328. There are varions sexomlary and supplementary grasses, surh as blue-grass, orohardwrass, red-top, and tall meatow fescule. Some or all of these may be userl in limited quantities. Seeds of all these weigh but fourteen pounds to the bushel, are usually sold in the "hatf, are not likely to be pure, and are difficult to distribute evenly. In most places, quite as much blue-grass aplears as a volunteer as is desirable, but, except in rape cases, it is not a profitable hay grass. Orehard-grass starts early, tends to grow in hummorks, does well in the shate and in close-erazed pastumes, but is thes worst of all gratsons in the latwh, where only tine, recumbent grasses and white rovers ale admissible. Red-top is a good pasture grass and lawn grass, and is well adapted to very wet meadows, althongh it does not make a first"lass hay. Tall mearlow fescue is one of the most promising resently introlncerl grasses for both mearlow and pasture. In many places it has escinged from the fields into the roadsides, where it shows its sureriority over blue-grass and eren over timothy. (of these glasses, from one to two bushels of serel are repuired per acre. All do well when sown in early spring or in fall. 


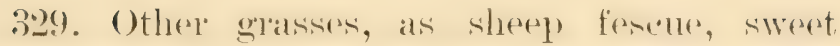
vernal erass, and similar dwart' grasses, alle not to be recommented for ereneral nse in America. Other grasses are adapted to sperial localities, as barley and wild oats, which are extensively used in California for hay. There is a wealth of native grasses, hut most of them give little promise for upland meadows.

\section{Other Forage Plants}

330. The plants alrearly discussed, together' with other coarser plants of the farm which are fed to domestic animals, are known collectively as forage plants; although this term is commonly applied to sureh plants as are not grown in pemanent meatows or pastures. By" rexpent rommon ronsent the term "poughage" has been substituted for them. Both terms are somewhat indefinite. The words nsually imply somewhat umeoncentrated, dried materials, to which some eoneentrated foor must be arded if ample growth, development and surplus products, as milk, are secured.

331. When forage plants are rot and fed gresen they alle called soiling plants. Theres ares several speries of plants, as, for instinnere, the prickly romfrey, which, if ferl meren, mat 
he nsed for soiling, but, if dried, are mupalatable.

3:3.2. 'The production of forage and soiling' "ropes is extremely simple. They may be intertilled or not. Large plants, which require abundant food and moisture and a full supply of smolight, as maize, shomld be tilled; lut small and puickly maturing ones, as barley, may be raised without inter-tillage.

3i3:). 'The two emeat forages plants of the [nited States are maire and alfalfal. The latter is well suited to the semi-ariel distriets of the Trest, and thrives to an astonishing degree in the bright sunshine of the Plains, when supplied with moisture by irrigation. It is peremnial, and several cotting may be taken eateh seasons. It is one of the legmomous arops, and, therefore, alpropriates nitrogen of the air. Like elover, it has a deep root-system.

:3it. But the kinge of all grasser, the one most useful, most easily laised and harrested, and the most produrtive, is Inclian (o) 11 , or maize. In a little mole than one humber lays from planting, from foum to six tons of air-elried stalks and from forty to fifty hushels of ervain may hes seremed from salch aleres or from twolve to twenty tons of memerd material may he secoured for the silo.

:3:5. Rre, though not a first-class forage or soiling plant, may le sown in the fall, cut when 
in head, and followed by a crop of Hungarian grass, which thrives in hot weather; and this in turn may be followed by oats and peas. There will not be time in the North for the oats and peas to mature, but they will remain green through November, and may furnish late fall pasture, or may be left on the ground to serve as a winter cover-crop (115).

\section{SUGGESTIUNS ON CHAPTER XII}

304a. It is impracticable to treat of specific crops in a text-book. Grass and forage are so fundamental to the conception of agriculture, however, that it will be profitable to discuss them, particularly as the cultivation of them illustrates some of the underlying principles of cropping. For advice as to the handling of particular crops, the enquirer must go to books on the special topies.

304b. The true grasses constitute the natural family of plants known to botanists as the Graminese or grass family; and this family includes all the cereal grains, as wheat, maize, and rice. In its largest sense, therefore, the word grass includes many plants which are not commonly recognized as grasses.

$304 c$. The term grass is popularly used to designate the medium sized and smaller members of the grass family, such as orehard-grass, timothy, and blue-grass, and not the larger grasses, as oats, sugar-cane, and bamboo.

$304 d$. The clovers are sometimes erroneously called grasses; and "a field of grass" may contain many kinds of plants. There are many kinds of clover. The common red clover is Trifolium pratense; the medium red is $T$. molium; the alsike is $T$. hybridum, with rose-tinted flowers; the white or creeping clover, or shamrock, is $T$. repens; the crimson, used for cover-crops, is 
T. incumatum. With the exreption of Trifolikm repens, these aro introduced from the Old World. The Japan clover, now much prized in the South, is really not a clover, but belongs to a closely related genus. It is known to botanists as Lespedeza

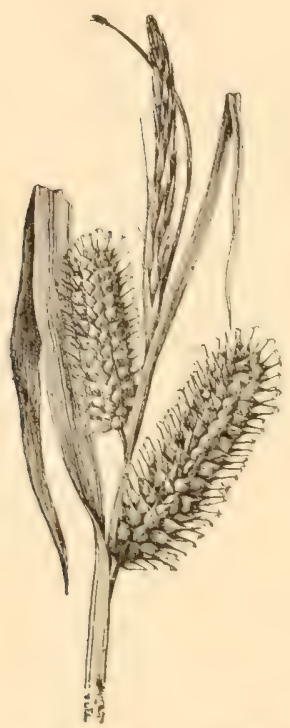

Fig. 74. A carex, or sedge.

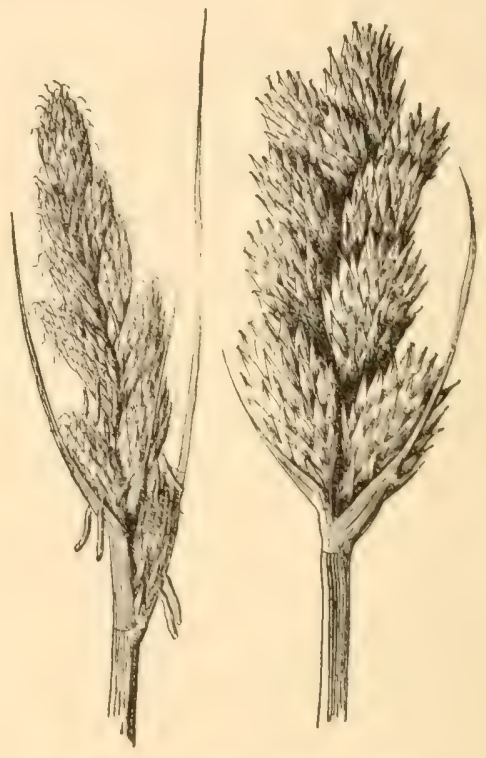

Fig. 75. A common sedge, or carex, in tower and when ripe.

striata. It was introduced aecidentally into South Carolina about 1849 .

30te. There are many kinds of grass-like plants. The greater part of these, at least in the North, belong to the closely related Sedge fimmily. Sedges are easily distinguished by 3 -ranked leaves aud usually by 3 -angled stems, with a pith; and the flower's are very unlike grasses. The sedges 
are generally worthless as forage plants, although some species in the West and South afiord acceptable cattle ranges when 3. grass is not to be had. Figs. 74 and 75 show y. common types of sedges, such as are frequent in swales.

$305 a$. In specialty-farming (4a), abundance of plant-food and humus material can be added to the soil, and rotations may not be needed; but in general or mixed lusibandry some kind of rotation is essential. Read Chapter xv., "Fertility of the Land."

3056 . The kind of rotation must be determined by the soil and many other factors. A four-year rotation, in which an exacting crop follows a less

Fig. 76 .

Timothy (Phleum pratense) $\mathrm{x} / 3$.

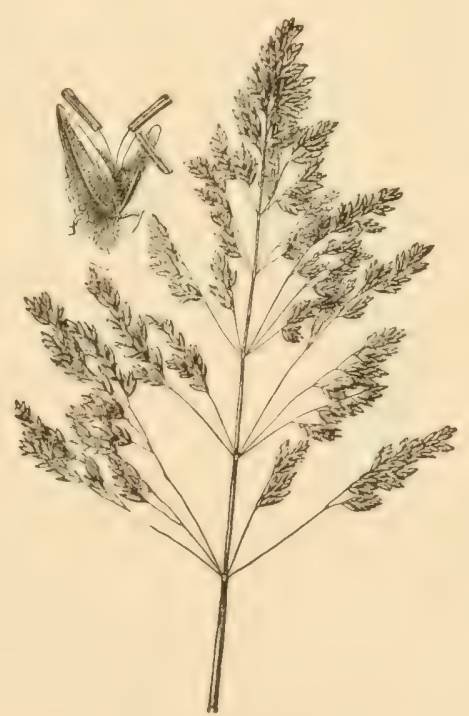

Fig. 77. June-grass or blue.grass (Poa pratensis) $x^{1 / 3}$. 


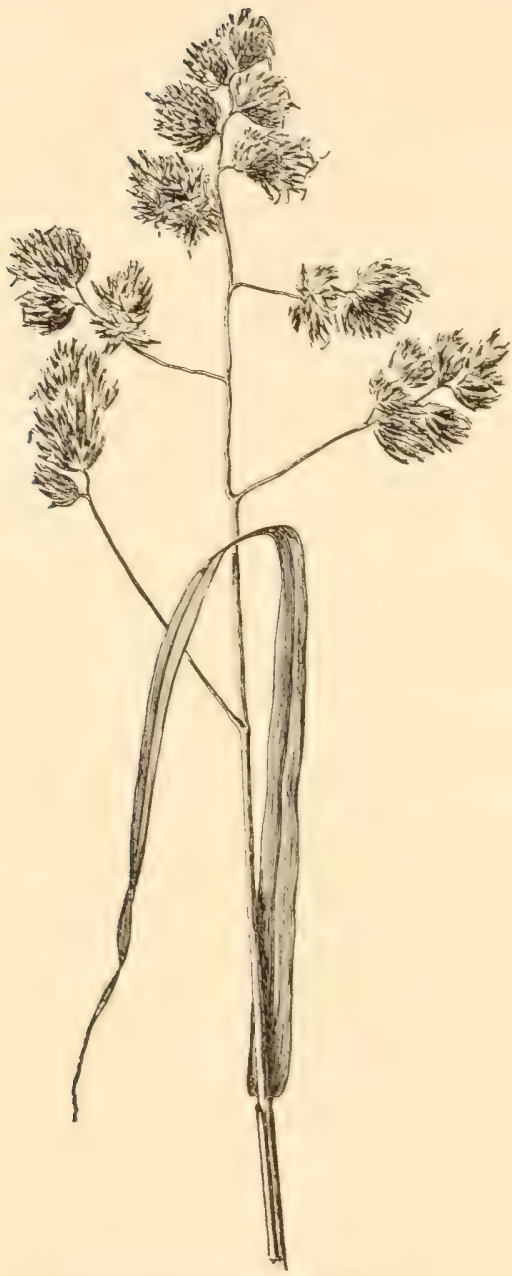

Fig. 78. Orchard.grass (Dactylis glomerata) $\mathrm{x} 1 / 8$.

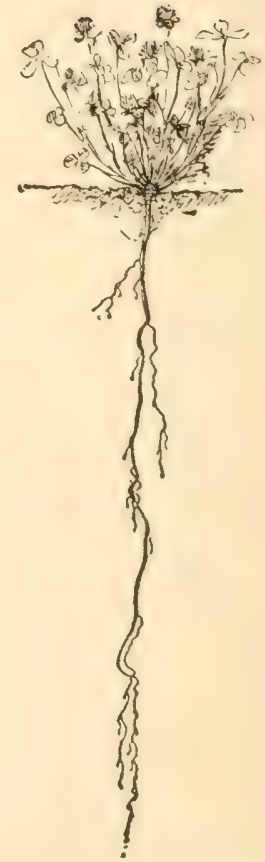

Fig. 79. Tap-root of red clorer. (Compare Fig. 33.) 
exacting one, and in which the elover root-borer is kept in check, is -

Clover, one year :

Maize, with or withont manure:

Oats ;

Wheat, with phosphates and manures.

A good rotation for "fairly fertile, lightish lands," is -

Clover, one year:

Potatoes:

Wheat.

A rotation for weed-infested land is -

Sod ;

Maize :

Potatoes or some other inter-tilled crop;

Oats or barley.

$307 a . \Lambda$ permanent pasture is one which is to remann many years without plowing. Some pastures, particularly on rocky or rolling land, remain undisturhed for a generation and more. Bermuda grass and Japan elover make permanent pastures in many parts of the South, but most grasses do not make good sod there. In distinction to permanent pastures are the temporary pastures which are a part of a rotation, or the meadow which is pastured after the hay is eut.

311a. The familiar Timothy is shown in Figs. 76 and 80. June-grass, with a flower in detail, is seen in Fig. 77 . June-grass is a common grass along roadsides, ripening very early, and is the best grass for lawns. Orehard-grass is illustrated by Fig. 78 .

$312 a$. The word host is here used $=$ in a different sense than by the botanist and entomologist (292b). Here it means a helper or companion, not a plant upon which another plant or an insect preys.

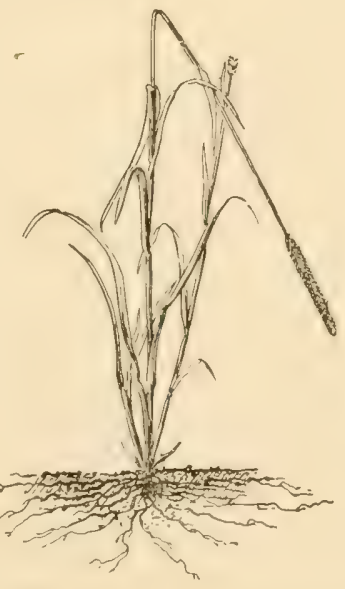

Flg. 80. Shallow root-system of timothy. 


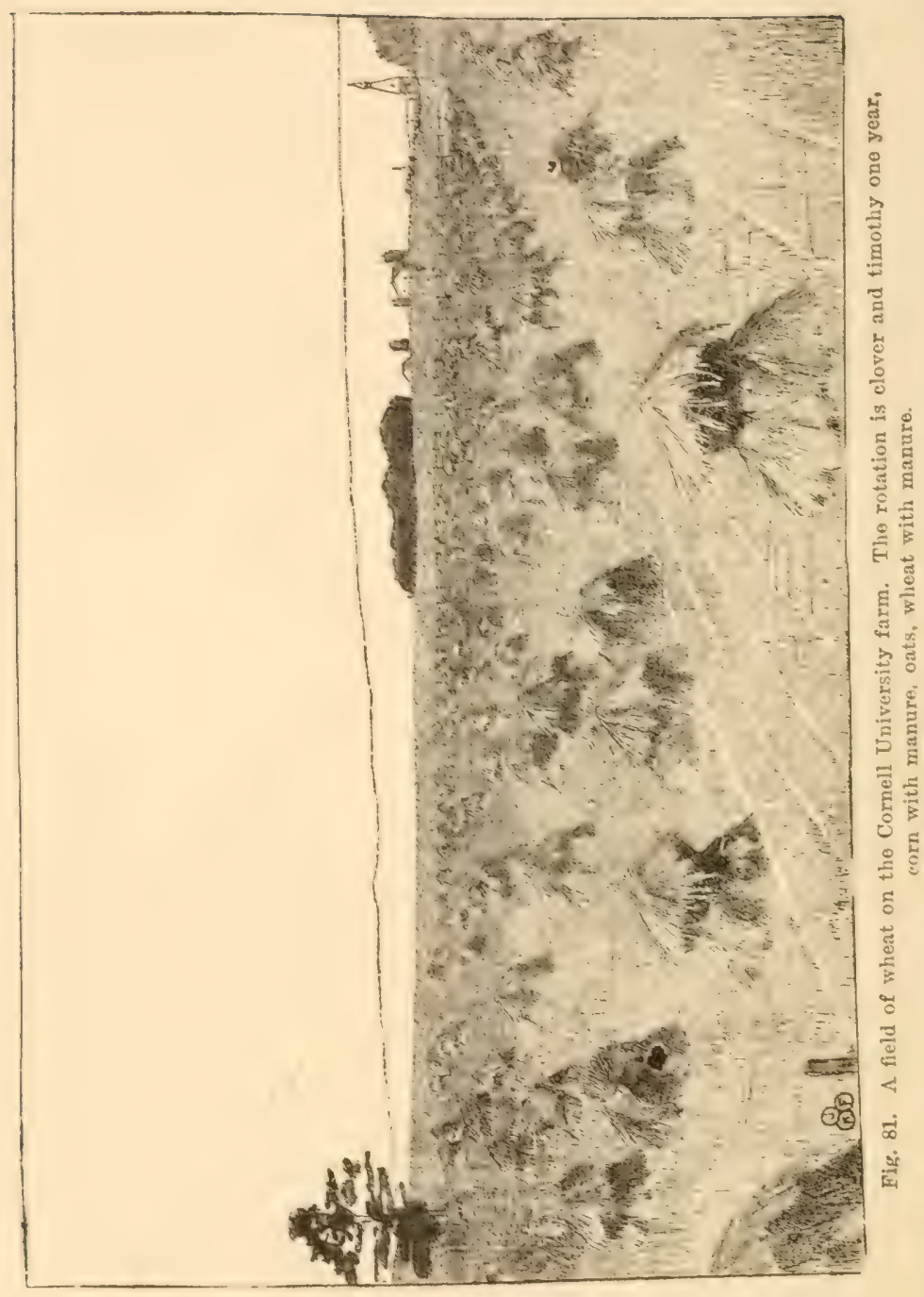


313a. ()heserve low different the ronts of rolover and timothy are (Figs. 79, 80). Ono fords in the subseil and subsurface soil, has many lithlo organisms on its pootlets, whireh aro called nitrogen-fixors (138); that is, they talse the fres nitrogen of the soil air, and it then becomes of use to the plant. The timothy has many small fibrous roots, which remain near the surface, and have, no nitmeron-fixing oreanisms. It will be

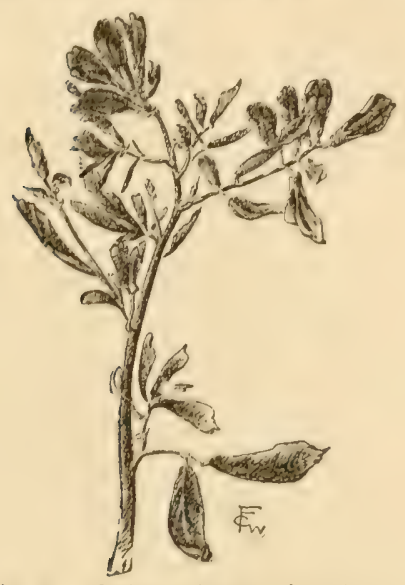

Fig. 82. Alfalfa or lucerno (Medicago sativa) $\mathrm{x} / 2$.

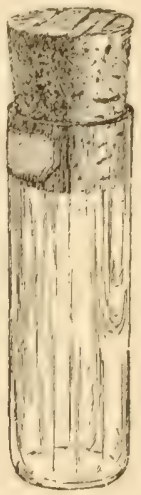

Fig. 83. A good bottle for seeds.

seen how appropriate it. is to maise these plants together: one feeds near the surface, the other down deep in the soil; one is long lived, the other short lived.

318 a. In general farming, the most uniformly good crops aro nearly always obtained when a rotation is used. Fig. 81 is a field of wheat, in a rotation, whirh yielderl over 30 hushels to the acre.

:32:3a. Tho permanent meitulows teatch many valuable lassons if they are studied clesely. Hero is often found a marked illustration of the strugerle for existeneo and of the survival of the fittest. Horo the farmer can give little lely by tillage, and 
small opportunity is afforded him to destroy the less desirable plants, that the more desirable ones may have better conditions.

333a. A sprig of alfalfa is shown in Fig. 82. It has small blue flowers in little elusters, and leaves of three leaflets. It is grown somewhat in the East, lnut it is most useful in the dry regions of the Plains and westward.

335a. All the plants mentioned in this chapter should be known to the pupil. In some schools, herbarium specimens mi $z$ be male of them. It is interesting and useful to eolleret seeds of farm and garden plants. The sehool house may rery profitably contain a eabinet of seetls. Tseful bottles are the "specimen tubes" sold by wholesiale drugrerists and natural-history stores. One is shown in Fig. \&.3. It is ${ }_{4}^{3}$ inch in diameter and 3 inches high, and can ho bought, without the corks, for about 30 cents per dozen.

For references on grisses and forige plants, consult Vol. II, Cyclopedia of Ameriean Agrieulture; Hunt's "Forage and Fiber. (rops in Ameriea;" Voorhees' "Forage Crops;" Spillman's "Farm Crasses of the United States." For the cereals, see Hunt's "Cereals in America." 


\section{PART III}

\section{THE ANIMAL, AND STOCK}

\section{Chapter XIII \\ THE OFFICES OF THE ANIMAL}

1. The Animal and the Stock

336. In an agricultural sense, the animal, as a. representative of the animal kingdom, has six general types of uses or offices: it aids in maintaining the fertility of the land; it provides a means of disposing of crops; it, or its products, may be of intrinsic value in supplying food and elothing; it works, or is a "beast of burden"; it may aid in keeping the farm clean of weeds and pests; it diversifies agrieultural oceupations; it affords employment for labor during the inclement months.

337. When animals are raised in quantity, they are spoken of as stock. This stock may be cattle, turkeys, sheep, ducks, swine, fish, or horses; but in common speech the word is applied mostly to quadrupeds (7). 


\section{The Animal in Its Relation to the Soil}

338. The first great resource for the improvement of the texture and richmess of the soil is herbage (108-111); the second is farm manures. When stock is pastured, practically all the manure is returned to the farm; but when it is housed, much of the manure is commonly lost through the carelessness of the farmer (120, $120 a)$.

339. The greater the proportion of stock to crop, the more fertile the farm should be ; for if the farmer must buy feed, the manure is gain, so far as the farm is concerned. In general mixed husbandry, stock is necessary in order to maintain fertility, as well as for its direct value; but in intensive (111a) and specialty-farming (4a) manures may be bought.

\section{The Animal in Its Relation to the Crop}

340 . There is not sufficient market for all the crops which the land can raise. Therefore, some of the crop may be fed to the animal and sold as meat, or butter, or eggs.

341. There is an important secondary gain in this feeding-ont of the crop, for part of the crop is returned to the land in the manure. Some 
crops, as clover, carry away much more plantfool, if they are sold off the farm, than the animal products which, in large part, are elaborated from them.

\section{The Animal Has Intrinsic Value to Man}

4a. As articles of food

34\%. Animals are direct sources of food. They contribute the various kinds of flesh, as beef, pork, poultry, fish.

:343. Animals are indirect sonrees of food, contributing of their products, as eggs, milk.

34t. Animals also contribute materials to various manufactured food products, as cheese, condensed milk, outter.

4b. As articles used in the arts

345. Animals contribute materials for clothing. Amongst such products are leather and wool. They also afford material for many articles of personal use, as feathers, bone, hair, glue, horn.

346. Animals contribute largely to fertilizing materials, particularly to substances containing nitrogen and phosphoric acirl. Amongst such materials, the most important are bones, dried blood, tankage; of secondary importance are 
hair-waste, wool-waste, fish-scrap, hoof-meal, various forms of horn.

\section{$4 c$ As companions}

$34 \overline{7}$. Many animals are pets, or companions to man, and the rearing of them is a species of agriculture. Of such are dogs, cats, rabbits, tame birds, and others.

\section{The Animal as a Beast of Burden}

348. The animal aids in tilling the soil. However much steam may be utilized for propelling implements of tillage, the horse and the ox will still be indispensable to agrioulture. Even the tramping of the animals over loose soils tends to compact and improve the land $(2506)$.

349. The animal supplies means of transportation. Even with the advent of the electric car, the bicycle and the horseless carriage, the driving horse will remain an inportant part of the far'm equipment.

3.50. The animal also supplies power for the driving of farm machinery, as threshing and feed-cutting machinery. On large farms, steam power must come to be more and more important, but on the smaller ones animal power will long remain an indispensable factor. 


\section{The Animal as a Pest-destroyer}

351. The browsing of animals aids in keeping weeds and wild growths in check. It is wellknown that pasturing with sheep is one of the best means of cleaning a weedy area.

352. Animals may keep insect and fungous pests in check by ating the fallen fruit or foliage. It is well known that swine keep the apple-worm in check by eating the windfall apples. Swine also root out and eat the white grub and other insects.

\section{The Animal Diversifies Labor}

353. The animal itself introduces diversity into farming. It also demands the growing of diverse crops. It enforces rotations of crops. Diverse interests educate the farmer, by demanding attention to many problems.

354. Some of the labor which is employed in summer in the growing of crops may be employed in winter in caring for stock. The animal, therefore, introduces continuousness into farming. The best laborer's demand employment the year round. 


\section{SUGGESTIONS ON CHAPTER XIII}

$338 a$. It is remarkable how the value of manure increases with the age of the country and the intensity of the agriculture. This comes as a result of experience, wholly without the teachings of seience, although science explains why manure is valuable, and points out many of the limitations of its use. The prosperity of the German peasint is measured by the size of his manure-pile. Gardeners place the greatest dependence upon manure; but they want it well rotted,-which means that they not only want its plant-food in the most available condition, but that they desire to utilize it laresely for its mechanical effect in loosening the soil with which it is mixed.

341a. A ton of elover hay removes about forty pounds of nitrogen, ten pounds of phosphoric acid and forty pounds of potash. A ton of butter removes about two and one-half pounds of nitrogen, and less than one pound each of phosphoric acid and potash.

346a. "Tankage is a highly nitrogenous product, and consists chiefly of the dried animal wastes from the lurge abattoirs and slaughtering establishments. It is variable in its composition, since it includes the otherwise unusable parts of the carcass, as bone, tendons, flesh, hair, etc. The portions of this from the different animals not only vary in their composition, but they are used in varying proportions, which naturally results in an extremely variable product. What is known as concentrated taukage,' which is obtained hy evaporating the fluids which contain certain extractive animal matter. is the richest in nitrogen, and is more uniform in character than the others ; and because of its fineness of division and physical character, the nitrogen contained in it is also more active than in the other forms." - Toorhees, Fertilizers, 43.

346b. Many other animal substances are used for fertilizers. Those which are used for their nitrogen are dried blood, dried meat, dried and ground fish, sea cribs, hoof meal. Those which are used for phosphates are the various forms and preparations of 
bone, as raw, boiled, steamed bone, bone ash and bone-black; also, dried fish.

$351 \alpha$. With all the remarks which have now been made on weeds $(22 b, 101,101 a, 117,267,267 a, 268)$, the pupil will see that the only fundamental and permanent way to escape weeds is through better farm management; and, to a less extent, the same conclusion will apply to insect and fungous pests. "I went by the field of the slothful, and by the rineyard of the man void of understanding; and lo, it was all gromn over with thorns, and nettles had covered the face thereof, and the stone wall thereot was broken down."-Proverbs xxiv., 30, 31.

354a. Upon the desirability of continuous employment for farm labor, Roherts speaks as follows when writing of rotations: "The baleful results of raising a single or few products in extended districts may be seen in California and the great wheat districts of the Northwest. In such localities, there is little or no true home life, with its duties and restraints; men and boys are herded together like cattle, sleep where they may, and subsist as best they ean. The work is hard, and from sun to sun for two or three months, when it abruptly ceases, and the workmen are left to find employment as best they may, or adopt the life and habits of the professional tramp. It is difficult to name anything more demoralizing to men, and especially to boys, than this intermittent labor; and the higher the wages paid and the shorter the period of service, the more demoralizing the effect. If there were no other reason for practicing a rotation with a variety of plants, the welfare of the workman and his family should form a sufficient one."-Fertility of the Land, 369.

For references on live-stock, consult Vol. III, Cyclopedia of American Agriculture: Roberts' "The Horse;" Plumb's "Types and Breeds of Farm Animals;" Mayo's "Care of Animals" (Diseases of Animals). 


\section{Chapter XIV}

\section{HOW THE ANIMAL LIVES}

JAMES LAW

\section{1. 'The C'ell, and Its Part in the Vital. Processes}

1a. The cell

35.5. The element in the body that earries on rital processes is the cell ; for life in the animal, like life in the plant (Chap. viii.), is devendent on the existence of cells. Each animal cell is a soft, jelly-like substance, held together by an exceedingly delicate network of fibers. It might be compared to a microscopic particle of raw white of egg.

\section{1b. Single-celled animals}

356. The lowest animals in the seale of existence are formed of a single cell, which in itself performs all the functions of life. This cell can move from place to place, by flowing out from its original globular form, so as to make a projecting arm, and by continuing to flow in the same direction until its whole substance has passed into the new position. 
357. This cell (an flow ont so as to surromur microsenpic particless and draw them into itself; these it can digest and use to increase its own substance. By reversing this process, it ran throw ont indigestible and waste materials. It an absorb, digest and build into its own sulpstance nutritive matters alpeady discolver in watre; and it can drive out waste, worn ont and injurious matters which it holds in solution in its own liquid.

:35. When the cell grows too large, it can divide into two independent parts, each having all the vital powers which belongerd to the parent cell or globule.

359. Thus the singlo-cellext animal ran makes of any part of its borly limbs for movinge, hands for grasping, fingers for foreling, stomareh for digesting, chamnels for the "irrulation of its nutritive liquids, as well as organs for excretion and for the increase of its kind.

\section{1c. Many-celled animals}

360. In all the higher animals there is not one cell, but myriads; and these cerlss are no less essential to life and to the healthy performance of all vital functions than is thes single cell of the lowliest organism. In the (o)mplex animal body, however, the cells build up solid tissues 
outside themsolves. As each aoll beromes imprisoned in a minute eavity in such solid structure, it is rohbed of those common powers or functions which belong to the single-celled animal, and is specialized for the performance of one constant, mehanging round of work. Each coll has its own work to do.

361. Cells may anry on processes of nutrition. Some cells lie in the microscopic spaces left in the hard bone, and ronduct the nutrition and rhamges in its substance. Other colls lie in the substance of muscle or sinew, or of brain, or of some other tissue, and no one of these can construct bone nol any other structure than that in which it lies. All such cells are engaged in carrying on the nutrition and growth of their respective tissues, and are reserved for this work only.

362. Colls may carry on nervous processes, being sot apart for vital work of a kind not directly connected with mutrition. Nerve cells,found in the brain, spinal-marow, and some other parts,-receivo impressions brought over the nerve cords from distant parts of the body. They generate and semel out nerve force to other parts. Some of these cells are set in motion by mental acts.

363. Certain other colls, which line microseopic sacs in organs known as glands, select from 
the blood the sereretion which that gland is appointed to furnish, and pour it out through the gland ducets. The secretion from one gland is nutritions, as in the "isce of milk; that from another is digestive, as in the serention of the stomaleh; and from at third it is waste matter, like

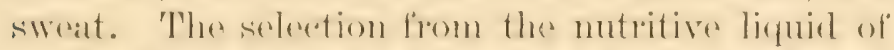
the blood is the work of the individual cells, amd is always the same for calch kind of elamel.

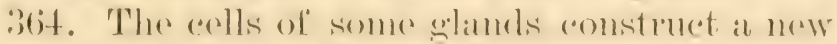

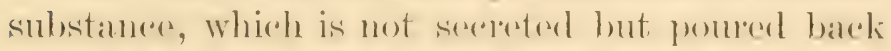
inte the hloot. Thus the liver makes gryogen, which passos into graple stlgarl, and servos for the problustion of heat, musculate work and nuttrition.

36i.). Somer arells on the walls of the intestines absorb nutritive and othere matters from the liquid contents of the bowests and fasse fheme on into the circulating (blool aml lymph) vessols.

366 . Besides these rolls which berome intprisoned in their particular tissnes, and the work of which is restricted to the amblueting of the growth or other functions of surh tissues, there is a large elass which floste fore in the linpuids of the body. The red and white blool eloloules and lymph cells are examples. Theses. globules or corpuseles arrenlate in all parts of the borly, thes sugeresting the frestom of the one-celled animal. But limitations have been 
set eren to these, the red globules being mainly curriers of oxygen, while the white also have restricted functions.

\section{The Food of Animals}

\section{2a. Find of food}

367. Food may be pither regetable or animal. Many animals, as horses, cattle and sheep, live on regetables, or are herbivorous; while others, like foxes and wolves, eat animal food only, or ale cannivorous. The food of the herbivoroms amimal has its nutritive prin(cip)les in a less concentrated rondition, and the herbivora are aceordingly supplied with more capacious digestive olgans. The same holds true of grain-feeders and grass-feeders among the herbivora. The grain-fed horse has much smaller stomach and intestines than the grassfed ox, and the rell-fed domestic rabbit has a much more spacious alimentary canal than his wild ancestor.

368. Artificial selection and forcing of meatproducing animals has a similar effect. The scrub ox, Texas steer and buffalo have light abdominal contents, while the pampered short-horn. Hereford, or black-polled ox has them heary and bulky. In the carnivora they are still more 
restricted. The intestine of the ox is about 160 feet long, that of the horse 90 feet, and that of the dog only 12 to 14 feet.

\section{2b. Food constituents}

369. All foods must contain chemical constituents which will serve to repair the waste of the body, to develop growing tissue, and to supply materials for the different secretions.

370. Asirle from mineral matters, all foor constituents which can build up the tissues must contain nitrogen, the element which forms fourfifths of the atmosphere, and which is an essential part of all body tissues. As familiar examples of such nitrogenous foods or aliments may be named white of egg (albumin), milk "urd (casein), and one of the soluble parts of flour (gluten).

371. As common forms of foods that contain no nitrogen, and which eannot form tissues, arestarch, sugar and fats. These are used up or burned in the system to produce borly heat, to stimulate the contraction of muscles, and to furnish secretions which are free from nitrogen, such as sugar and butter-fat in milk, and sugas (more properly glycogen or sugar-former) in the liver.

372. Both sugar and fat, however, can be formed in the body from nitrogenous food, as 
in the milk of the carnivorous animal when red flesh only has been fed. In this asse the origimal nitrogenous food is broken up into two or more chemical products, one of which eontains only cartum and hydrogen, or these with the matition of oxyeren, white all of the nitrogen goes to other product or products.

:7:?. Nineral salts $(15-11)$ form a thirel gromp of fool principles. These ance essential in repairing the waste of tissues, and in forming sereretions like milk, bile and wastrie juice.

:37. The ideal food eontains all of these three groups in forms which ean be dissolved, digested and assimilaterl into the animal tissues. Milk is an ideal food. In it the non-nitrogenous aliments-sugar, butter-fiat-ale mited with the nitrogenous-casein, allumin,-and with the salts in proportions arlapted to the needs of the system.

375. A well-balaneerl ration for the adult animal is one in whith these difterent elasses of food constituents bear a somewhit defmite relation to abeh other, due allowamere heing made for the uses to which the animal is put. The growing, working or milking animal requires more of the nitrogenoms elements, while the fattening animal may exchanger much of this for the nonnitrogenous.

376. The living hody, howerer, is not like a 
simple machine, which can, in all cases, turn out a product exactly corresponding to the chemical food elements which are turned into it. The vital element has always to be reckoned with. One animal demands a little more of this class of aliment, and another a little more of that, in order to secure the best results; while in all cases palatability and facility of digestion have a controlling influence.

\section{Digestion of Food}

3a. What digestion is

377. Digestion is the process by means of which the food becomes dissolved so as to be taken up by the blood. It takes place in the alimentary canal,-the mouth, stomach, and intestines.

378. Digestion takes place under the action of different secretions, each of which operates on special constituents of the food. Considered in the order in which they mingle with the food, these digestive secretions are: (a) saliva; (b) gastric juice; (c) bile, (d) pancreatic juice, (e) intestinal juice.

3b. The saliva

379. Saliva is furnished by a group of glands located under the tongue, in the cheeks, and 


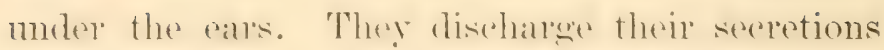

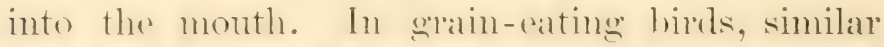

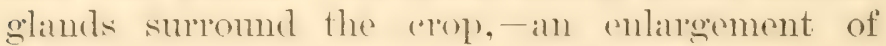
the gullet in the region of the neck.

:3(). I ferment (p)yaliu) in the saliva arets on the stareh in the ford, eatsing it to chemically mite with alditional water and berome

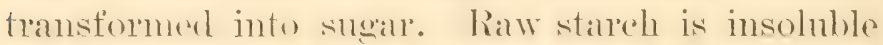
in water, and (anmot liss into the colvenlation; but the susen formed from it is fredy soluble, "int be reatily alsopled into the hlood, and contributes to the activity, mowth and nomishment of the body.

:31. The ptyalin alets slowly on raw starch, amel much more rapielly on boiled stareh, so that cooking of regetable food farors its digestion. It acts hest in the absener of acids. It is less active when weak organic avids are present, and its action is alrested in the stomach by the free muriatic or hvdrochloric acid.

:38. In animals with one stomach, therefore, it is important that the fool should be thoroughly masticater amd satmated with saliva, and not holted whole, or impertectly insalivated. In ruminants (ol ("nul-(oh('wing animals), as eattle, sheep and roats, the fool is lomg delayed in the first thres stomachs, in which any slight sompness whioh may exist is due to mild organie acids only; and, therefore, there is ample 
time and olportunity for the full rligestion of the starch.

35. Digestion is further favored in these animals by the chewing of the curl, by means of which the solirl portions are returnorl to the mouth, morsel by morsed, to be laisurely gromed down and again saturated with saliva. Digestion is more thoronghly accomplisher in the third stomach, in which the? foorl is ground to the finest bulp between the one humbled folds, large and small, whirh fill its interior.

384. This thorough breaking up or comminution prepares the food for the easy digestion of its nitrogenous principles in the fourth stomach. The removal of the starch renders eren the finest particles of food more porous, and permits the prompt and speedy action of the stomach juices on its whole substance.

385. For some time after birth, the salivary glands produce little saliva, and still less ptyalin. This is in kesping with the exclusive mill; diet, in which there is no starch to be acted upon. For this reason, any starchy food in the early days of life is out of place; for, as it cannot be changed into sugar, nor alsorbed until it has passed through the stomach and reached the intestine, it is liable to ferment and to form irritant products, and indigestion. 
The addition of snch elements to the food should be made later and a little at a time.

\section{3c. The gastric juice}

:866. The stomach produces three digestive principles, which may be sepalately considered: muriatic or hydrochloric ache pepsin, the milkcurdling ferment. These materials comprise the gastric juice.

387. Free muriatic acid is strongly antiseptic, especially checking such fermentations as oceur in the alkaline or neutral saliva, in the first three stomachs of ruminants or in the crop of the hird. This exposure of the food successively to alkaline saliva and acid gastric juice kills off myrials of bacterial ferments which would otherwise reach the intestine, to prove inritant or poisonous. Many still pass into the intestine in masses of undigested food, or hecause they can survive both alkaline and acid solutions, or hecause they have passed into the condition of spore, which, like the dried seed of plants, is comparatively indestructible.

388. The muriatic acid further softens, disintegrates, and dissolves the rarious nitrogenous food principles (coagulated allumin, fibrin, gelatin, casein and vegetable gluten).

389. Pepsin is a ferment which is secreted in 
glands found in the end of the stomach nearest to the intestine. It acts on the nitrogenous principles in the food, which are made to take up water, and to change into a much more stable and diffusible liquid called a peptone.

390. Peptones of a great number of different kinds are produced from the raried food principles-from such as fibrin, albumin, gluten, casein. The peptones all agree in certain common characters: (a) they are easily and completely soluble in water (fibrin, coagulated albumin and casein themselves, are not soluble); (b) they filter rapidly through animal membranes, such as a bladder (the agents from which they are derived do not); ( $r$ ) they are not thrown down as solids by boiling or by strong acids (albumin and casein are precipitated by strong acids, and albumin by boiling).

391. Peptones are thus easily absorbed inte the blood, while the absorption of the original principles from which they are derived would be exceedingly slow and difficult. Pepsin acts much more rapidly in an acid medium, so that it is specially adapted to coopperate with the muriatic acid.

392. The milk-curdling ferment is the product of the gastric glands. It is utilized in the manufacture of cheese. Like pepsin, it acts best in the presence of muriatic acid. One part of 
this ferment will coagulate 800,000 parts of casein.

393. In birds the gastric juice is secreted in an enlargement of the gullet (proventriculus) just above the gizzard. The strong museles and cartilaginous lining of the gizzard serve, with the pebbles swallowed, to grind down the food into a fine pulp and to mix it intimately with the gastric juice.

\section{3d. Intestinal digestion}

394. Cnder the action of the saliva and gastric juice, the greater part of the starch and nitrogenous matter is usually digested before the food materials pass from the stomach into the intestines. The products of digestion are mainly sugar and peptones. The fatty matters,--set free hy the digestion of their nitrogenous enrelopes,the undigestible portions, and such digestible matters as are as ret not acted on, pass on into the intestines, mostly in a finely divided semifluid condition.

395. In the intestines, the materials are acted on by bile, pancreatic juice, and intestinal juice. These fluids are alkaline.

396. Bile is secreted by the liver. It is poured into the intestines a few inches beyond the stomach. It renders the contents alkaline, checks fermentation, stimulates the movements of the 
bowels, and transforms their fatty contents into an emulsion which penetrates an animal membrane, and is absorbed with great rapidity.

397. Bile has, besides, a limited power of changing starch into sugar. It is also useful in carrying waste matters out of the body.

398. Pancreatic juice is poured into the intestines by a canal which in certain animals unites with the bile duct. It contains at least four different ferments: (a) Amylopsin, which, at the body temperature, rapidly transforms starch and even gum into sugar, thus completing any imperfect work of the saliva; (b) trypsin, which, in an alkaline liquid, changes nitrogenous matters into peptones, thus finishing any imperfect work of the stomach; (c) a milk-curdling ferment.

399. The pancreatic juice, as a whole, acts like the bile in causing fats to form emulsions. It even breaks up the fats into fatty acids and glycerin.

400. Intestinal juice is a complex mixture of the different secretions alrearly namer, together with the products of the glands of the intestinal walls. The secretions of these walls act like pancreatic juice, only less powerfully.

401. As a whole, the digestive agents thrown into the intestines cover the whole field of digestion, and largely make up for any defective 
work of the saliva and gastric juice. Even in cases in which the stomach has been removed, the intestines have taken up its functions and have maintained a fair measure of health.

\section{Absorption of the Digested Matters}

\section{4a. How absorption takes place}

40:2. The fool principles, digested or emulsionized, as hefore stated, are now absorbed into the blood and lymph ressels, ehiefly through the villi of the intestines. These villi are minute hairlike projections from the lining membrane, from $\frac{1}{50}$ to $\frac{1}{30}$ of an inch in length. Ther are covered with soft cells, the deeper ends of which reach the capillary blood-resisels and lymphatics ocenpying the interior of each villus.

40:3. The cells of the villus take in the liquirl products of digestion, and pass them on into the ressels beneath. Br a muscular contraction of the villus, these ressels are emptied at frequent intervals into the larger veins and lymphaties in the walls of the intestines.

404. The interior of the small intestine, which immediately follows the stomach, is covered throughout by these villi. Owing to the rapid absorption conducted by them, the soluble contents of this intestine are in great 
part removed and transferred to the eirculatory system before the large intestine is reached.

4b. Destination of the rich blood from the intestines

405. The veins from the stomach and intestines carry the rich products of digestion into the capillaries of the liver. Here they not only contribute to produce bile, but also new combinations of nutritive and other compounds, which pass into the general eirculation.

406. One of the most important of these new products is sugar, which, as already stated (372), is formed even in the liver of animals fed on a strictly carnivorous diet. The importance of this product may be inferred from the fact that the liver is very large in the young and rapidlygrowing animal, and also in mature animals of a meat-producing race: these animals have extraordinary powers of digestion and fattening.

407. Another important function of the liver is the transformation,-largely by union with additional oxygen,- - of worn-out or effete red globules, and of much of the useless nitrogenous material in the blood, into urea and other soluble products. These products are fimally passed off by the kidneys. They afford a stimulus to secretion by the kidneys, and supply an abundance of material which can pass readily througn 
these organs without causing irritation or derangement.

408. Another important liver function is the transformation of peptones (which are poisonous when thrown into the blood in any considerable quantity) into products which are non-poisonous, and are capable of assimilation. These produets form tissue, or fulfill some other important use in the body.

409. Still another important use of the liver is to transform into harmless compounds the poisonous products of bacterial fermentations (such as ptomaines and toxins). These oceur in the contents of the intestine, and might often prove deadly if allowed to pass this guardian sentinel-the liver-in any considerable amount.

\section{Respiration, or Breathing}

5a. What breathing is

410. Breathing cousists in the substitution of oxygen of the air for carbon dioxid in the blood and tissues of the animal body. It results in the combination of the oxygen of the air with certain organic constituents of the system; and it fits these constituents for various uses, or for elimination as waste matters. 
411. In the main, the air is changed in breathing as follows:

Oxygen Nitrogen dioxid

Inspired, or breathed-in air contains . . . 20.81 $\quad \begin{array}{lll}79.15 & .04\end{array}$

Expired, or breathed-out air contains . . $16.033 \quad 79.557 \quad 4.38$

In every 100 parts, air loses, by being breathed, about 4 parts of oxygen, and gains about 4 parts of carbon dioxid.

412. In breathing, the air is also charged with water vapor and with small quantities of ammonia and marsh gas. It also receives a volatile organic matter, which may be foetid, and when condensed in water soon develops a putrid odor.

413. In the breathing process, the blood and the air are brought into the closest possible contact. One-celled animals breathe through the entire surface, fishes through gills wared in the water, from which they abstract oxygen, frogs through the walls of a simple air-sac, in which the blood-ressels circulate. In warmblooded animals, this sac $\mathrm{or}^{\circ}$ lung is divided throughout into myriads of minute air-sacs or (.ells, varying from $\frac{1}{200}$ to $\frac{1}{70}$ of an inch in diameter. The walls are so thin that the blood flowing through their capillary ressels is constantly exposed, on two sides, to the air with which they are filled. The membrane constituting the walls of these sacs is so exceedingly 
thin and permeable that gases pass through it with great rapidity, - the oxygen from the air to the blood, and the carbon dioxid from the blood to the air.

\section{$5 b$. Blood-changes in respiration}

414. The heart of wam-blonded amimals is composed of two double arvities, right and lett, which are quite distinct from earh other. The left side pumps the blood into the alteries of the system at large, whence it returns throngh the reins to the right side. The right side, in its turn, pumps the blood into the arteries of the lungs, whenee it returns by the lungreins to the left side. In this way the blood is circulated first thromgh the lmoss, and then through the tissues of the rest of the body.

415. The blood is of a dark red or purple color as found in the reins, in the right side of the heart, and in the arteries of the lungs. It is of a bright crimson hue as it returns from the lungs and passes through the left side of the heart and the arteries to all parts of the body. The varying color is determined by the presence of a larger amount of oxygen in the arterial (bright crimson) blood, and by its comparative absence, and by the presence of an excess of carbon dioxid, in the renous (dark red) blood. 
416. The difference between the artery-blood and vein-blood is shown in the following table:

Vols. Vols. of of carbon oxygen dioxid

From 100 vols. of arterial blood may be obtained .. $\quad 20 \quad 39$

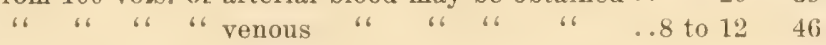

417. The excess of oxygen in the arterial blood is used up as it passes through the calpillaries, and is replaced by carbon dioxid. The excess of carton dioxid brought bark by the venons blood is thrown out into the air filling the lungs, and is replaced in the blood by the oxygen taken up from the air. The rarbon dioxid is made up of one atom of carbon obtained by the breaking up of the tissues or blood elements which contain carbon, and of two atoms of oxygen carried to such tissue or element by the blood.

418. Breathing, therefore, or the combination of oxygen with carbon to form the carbon dioxid, really does not take place in the lungs, but in the various parts of the body to which the blood carries the oxygen.

\section{5c. Amount of air required}

419. The amount of carbon dioxid passed into the blood and exhaled by the lungs is increased by exercise, work, sunshine and food; hence the necessity for more rapid breathing 
under such conditions. The amount also varies with the kind of animal. The pig produces more in proportion to his body weight than the carnivora, rabbit, and fowl; and these again produce a larger proportionate amomnt than the horse or the ox.

4:0. Air which contains 10 to 12 per cent of carbon dioxid will no longer sustain life. The deleterious effect is due partly to the lack of oxygen in such re-breathed air, but also to the excess of the poisonous carbon dioxid, volatile organic matter, and other injurious protucts. Air which contains even 1 per cent of carbon dioxil produced by breathing is injurious to a markerl degree. In a perfectly close place, where there can be no access of fresh air, a horse would contaminate to this extent orer 7,000 cubic feet in 24 hours.

421. The question of stable space, however, is dependent on the amount of air that can be introrluced by ventilation in a given length of time. 'The tighter' the building and the less the admission of fresh air, the greater must be the area supplied; while the greater the facility for the entrance of fresh air, the smaller need be the space per animal. If the whole of the air conld be removed every three hours, 1,000 cubic feet per horse or cow would suffice to keep the air sufficiently pure and wholesome. 


\section{Work; Waste; Rest}

6a. Waste of tissue

42.2. Under borlily labor, the elements of the muscles are used up to a certain extent, while heat and waste matters are produced. A period of rest is required to allow for repair of this waste. We see this carried out in all healthy bodily functions. The heart, after each contraction, has a short rest before the commencement of the next contraction. The muscles that carry on breathing work in relays, those that dilate the chest resting while those that compress the chest are in operation. Then both rest for an interval before the next inspiration is commenced. This provicles for rest and repair of both the muscles and nerves. Except for such rest, both would soon be exhausted and wasted beyond the power of work.

429. The waste of tissues, however, is not always in exact proportion to the amount of work. On the contrary, it has heen shown hy careful experiment that the waste of the working muscle is but a small part of the expenditure made. The heat- or fat-producing matters in the food are also used up in such work. The process may be likener to fuel supplier to the engine, which contributes to keep it running 
with the expenditure of lont a small part of its own proper substance. Thus the stareh and sugar in the diet contribute not only to maintain heat and to lay up fat, hut also to render possible a large expenditure of muscular energy and work.

\section{6b. Applications to practice}

t't. Such expenditure of food and muscular energy in producing heat and work prevents the laying out of the same capital for other uses, such as growth, fattening or milking. In domestic animals, which ean be mofitably kept only when adapted to special uses, expenditures in other directions must he limited as far as may he in keeping with the maintenance of health.

4.5. For rapid fattening, rest and warnth and seclusion are farorable. Even the mileh cow, put in the stable in good health, may be male to give more milk for a time when kept idle in a warm stall than when tumed ont to gather her food from a pasture. 'This, however, cammot be safely carried to extremes. The continnous disuse of the museles tends to their waste and degeneration, to an impoverishment of the blood, to a loss of tone of the nerrous and other organs, and to a gradual lowering of vitality. For animals that are soon to be sacrificed to the butcher, this is not to be considered; but for such as 
are to reproduce their kind and keep up the future herd, a moderate amount of muscular exercise is as important as suitable food and hygiene.

426. The animal body is a very complex organism, with an almost endless variety of parts and functions, each of which is more or less essential to the full usefulness of the whole. The best condition of bodily health is that in which all of these are properly adjusted to each other and to the surroundings. In the case of farm animals, the complexity is the greater becanse the natural functions must be developed here and restricted there, to make them a profitable possession; and all this must be done within limits which will be compatible with the maintenance of health and vigor.

\section{SUGGESTIONS ON CHAPTER XIV}

359a. The best illustration which the pupil can secure of a single-celled structureless organism is the arnoba (Fig. 81). This lowly animal lives in stagnant pools, and can be secured by seraping the scom off the stems and leaves of water plants. In its larger forms it is barely visible to the naked eye.

3596. The Fin. 8.) shows a spindle-shaped (involuntary) contractile ceil or fiber from the muscular layer of the intestine, showing nucleus in white and nucleolus in black. It has no such variety of functions as the amoba has.

360 . A part or an organism is said to be specialized when it is fitted for some particular work, rather than for general 
work. A cell which has to do only with nutrition is specializad; one which has to do with nutrition, sensation, locomotion, and reproduction, is generalized. A cell may bo saicl to be

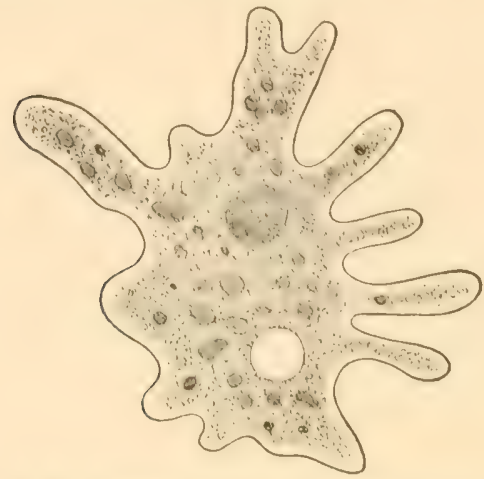

Fig. 84. Amooba, showing large, round nuclous near tho top, enclosing a nucleolus, many granules, protruding arms of protoplasm, and wile space round which tho proto. plasm has tlowed, Magnilied 200 diameters.

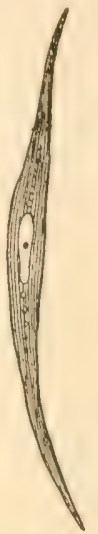

Fig. 8ij.

Musclo cell. Ingnified.

still further spereializel when it rarries on some particular or special part of nutrition.

$363 \pi$. A secretion is a material derived from the blood and poured out into tho body. When this matorial is of no further use, it is eliminated, or removed from tho body, and is known as an excretion. 'l'ho saliva, eye-water, bile, gastric juice, are examples of secretions.

363b. Glands are secreting organs. 'Thus the salivary glands secrete or make the saliva or spittle, from the blood. 'The liver is a gigantic gland, secreting bilo and other materials.

$36+a$. Glyeogen is very like stareh. In fact, it has the samo

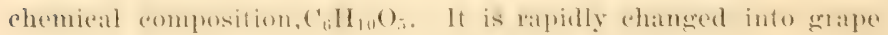
sugar or glueose by the action of saliva and other juices, and it then beromes avaliahle for the hublemer of tissue or liepping up tho bodily heit. 
$365 a$. Lymph is a product of the blood. It is a pale liquid which transudes from the thin or anpillany hlood vesisels, amel is nsed to nourish and build up the tissuns. The lymphatide system carries food materials to the plateres where they are neederl. See $409 b$.

36 tite. By the almentary eanal is meant the whole digestive tratet, beginning with the mouth, and eomprising the gullet or esophagus, the stomach, the small and large intestines.

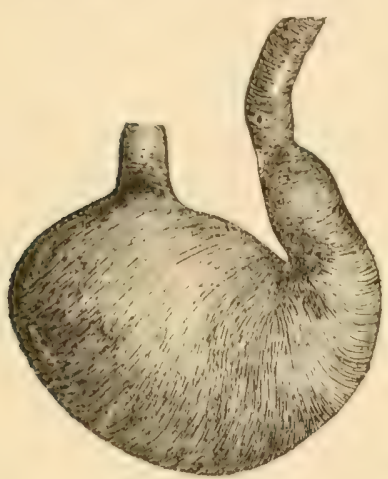

Fig. 86. Stomach of dog.

371a. The fats contain earbon, hydrogen and oxygen, but the oxygen is in small proportion. One of the common fats (palmatin) has the composition $\mathrm{C}_{51} \mathrm{H}_{98} \mathrm{O}_{6}$; another (stearin) is $\mathrm{C}_{57} \mathrm{H}_{110} \mathrm{O}_{6}$.

379a. In physiology, the word ferment is used to designate substances which have power to make starch-like materials soluble by converting them into sugar-like materials. These ferments, of which ptyalin is one, are secretions. They are also called onzyms. 'These secretions may be the products of cells in the animal body or of independent microorganisms. The micro-organisms ate themselvers often ealled ferments $(35 a)$.

$382 \alpha$. The single stomach of a carnivorous animal is shown in F'ig. 86. 'The stomach of a ruminant is well illustrated in Fig. 87, the front walls being ent away to show the internal structure. It has four divisions: $C$, paunch; $R$, reticulum; $N$, manifolds; $O$, the true digesting stomach.

$385 a$. There are various experiments which the pupil can perform. Mlix a little well-boiled stareh with a small quantity of saliva, and after a time it will be found to have become sweet. If at the outset a drop of solution of iodine is added to the mixture it will produce a blue color (203b). As the stareh is chamged into sugar, this color sratually foules and in the end disappears. 
isio. An antiseptic is any material which destroys germs or baveria (2sta). The muriatio or hytrobloric acid is present in sm:all amounts, rumsing from 0.2 to 0.8 and upward in 1.(1)(1) parts in the different kints of animsls.

:isib. A substamee may be and or somr, in which case it turns blue litmus red $(15 i$, , libut). It may be alkaline, as lye,

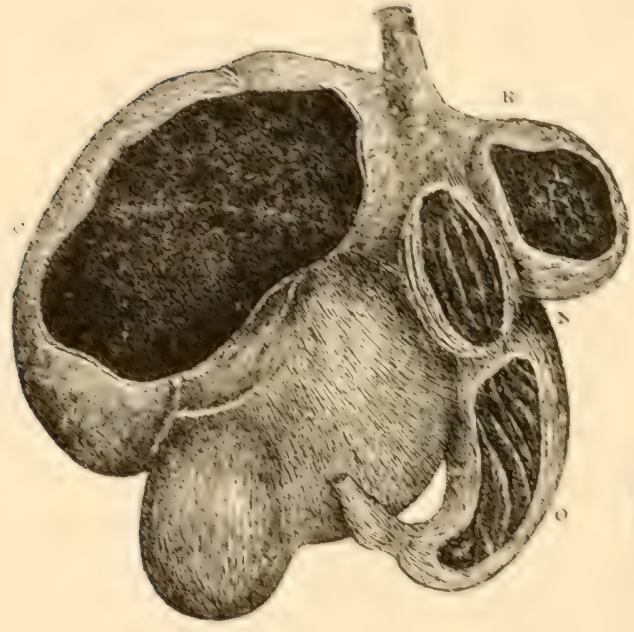

Fig. si. stomah of sheep.

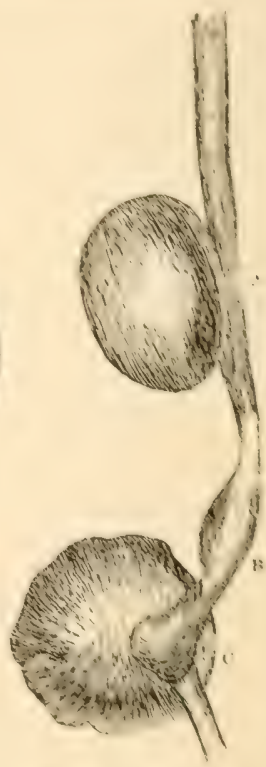

Fig. EN. (m) snd giz:ard of fowl.

in which ease it turns red litmus blue. It may be neutral, giving neither reation.

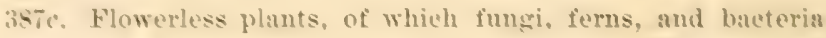
are examples, do not produee seeds, hut spores. These spores are usually single eells, and eontain no embryo. They can

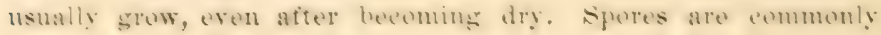




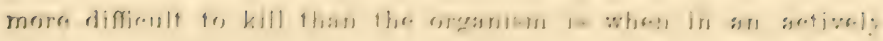
growing condition.

390ra. A proceipitate, in chernistry, is a more or loses solirl

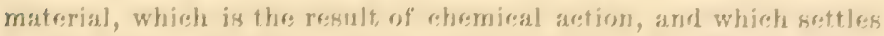
to the bottom of the liquid in which it is formed. 'Thus, let thas pupil blow through a straw into a brottes of lime water. The lifpuid will becomes cloudy, and aftere a times thes serdiment will

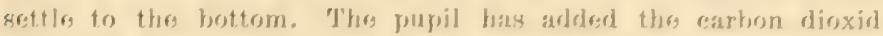

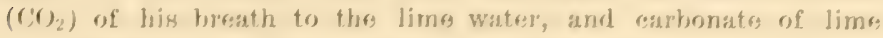
(or limestone) has beren formesl. Compars 194a.

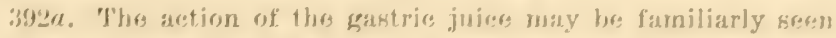

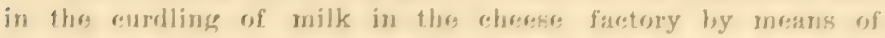
rennet. A littles minesernest mixed with the serapings of thes lininge memborarse of a pig's stomareh, rendered slightly aroid by a drope or two of muriatire aceid and kept near horod-hest

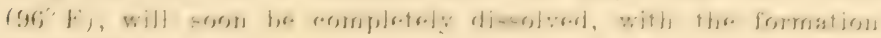
of peptone.

392b. Rennet is the digestive principle derived from the fourth stomareh of ruminants (6), Fig. 87). This stomach is taken from calvers and dried; and the stomach ifself is thon spoken of as renuet. 'The stomareh of adult animals conld also the uscerl, if necessary.

3934 . 'The gastric apporatus of a chicken is shown in Fig. 88. 'The coroly is at $a$, the proventriculus at b, and the gizzard sit $c$.

396in. An emulsion is that romdition in which fatty or nily materials ars so intimately mixed with the liquid in which they ares placed that they acet much as if. they weres in aretual solution, even passing through membranes. Most famers are now familiar with the keroseno emulsion, used as an insecticide (296; $a)$.

399a. Glycerin is a colorless liquid which is associated with fats or fat-acids, and which may bederived from them. Its

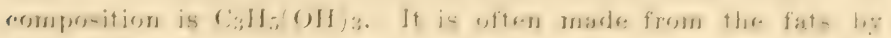
artificial means, and is used in medicino and the arts. Also spelled flycerine.

$402 a$. 'T'wo villi are shown in Fig. 89. The singular form of the word is villus. 
404r. In commection with intestinal digestion and absorption, the bile tills a specially important ecomomic function, in supplying many of its ingredients to be used orer and orer acain in the comrse of the same diy. 'T'he bile stimulates in a high degree the absorption of the digested products, entering with them into the veins. As all the blood returning from the intestines must pass through the liver, the elements of the absorbed bilo are secreted anew and once moro poured into the intestine. Hence a small amount of bilo performs a very large amount of work; and hence, too, any suspension of the secretion of bile interteres serionsly with the general health.

409 . A ptomaino (promonneed tó-main) is a material formed from the decomposition of deat tissue. It is alkalime, and often poisonous. The poison in umwholesomo ice-cream, for example, is a ptomaine. Ptomaines often result from the destructive work of mierobes. Tho term toxin is applied to a poisonous product of fermentation, whether alkalino or neutral.

4096 . It mar bo well to spenk of the destination of the enyle. Chyle is the liquid formed of the materials absorbed

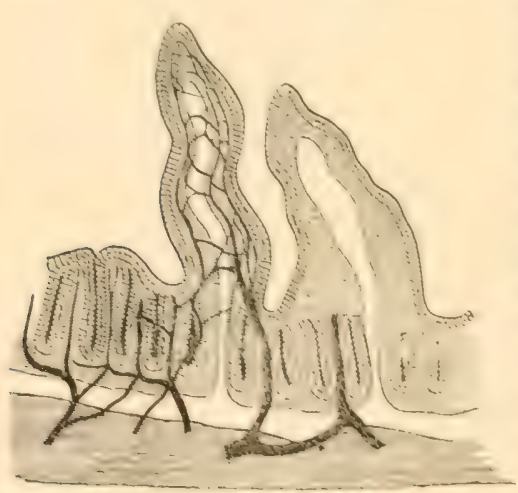

Fig. si. Surface of mucous membrane of the intestine, showing villi with central lacteal duct and blood ressels, and on the surface the absorbing enithelial cells. from the howals into the lymph ressels. It is albuminous (nitrogenous) and fatty, with a white, milky color. 'Jhis, like the lymph in the other Iymph ressels in various parts of the body, contains white, spherical, microseopic cells, which aro greatly increased after passing through the lymple glands, and when poured into the blood become white blood globules. During the intervals in which there is no digestion, the lymph or chrle in these intestinal ressels, as in other 
parts of the borly, is a simplos straw-oologed linuid romsisting of surplus nutritive matter which has not been required by the needs of the part, and is being returned to the blood. In this lymph wo find an important source of supply of the white blood globules, which aro being constantly used up; arul thus derangements in the lymph vesseds and chlamels injuriomsly affort the hood, and through it the rutire animal system.

409b. The admirable adaptation of means to end is traceab?o in the successive changes of these food products. The nitrogenous constiturats in the food, which are not fitforl for absorption, ale transformed into the peptomes, whirh atre spe.

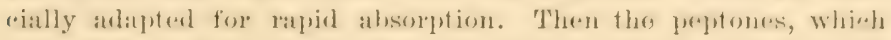

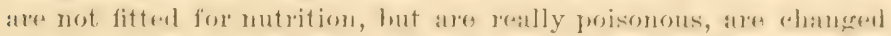
in the liver, so as to render them harmless and fitted for the varied uses of the body, or for elimination. Other food principles ares turned info sugrer, and somet poisonous formentation probures ares rendereal hambess through the action of the liver.

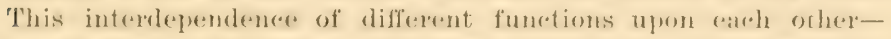
mastiation, issalivation, digntion, absenption, transformations in the livere, the formation of normal blood elements, ascimilation and sereretion-furnishes an inderation of what gores on

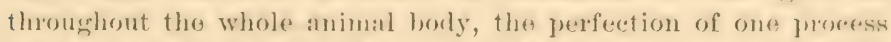
being essential to that of others, and the derangement of one ratusing disorder of the others. 'The nervous system, whirelt is eoncerned in carrying on all functions, from those of simple mutrition of a tissue or of soreretion by a gland up to such mental proeesses ats the animal is endowerl with, is dependent on the hoorl for its own functional atetivity. Changes in the bloord entail change in tho capareity for urervons work ; so that disorder of one distant orean, aeting hy influrecing the nervous system, direetly through the nerves or indirectly through the hlosed, may bringe about deranerements of the most variend kind in the diffrent organs subject to nervous influenee. 'The frreat funcetion of the lunges is the elimination of carbon dioxiel from the hlood and tissurs and the intredurtion of oxyonen, which, bejer carried into all parts by the red globules, assists in nearly every chango which takes place in any organ. But if the lungs 
fail to fultill their function to any degree, every organ and function is atfected. Most of the waste nitrogenous matter leaves the boly through the kidneys. but it this chammel of elimination is intertered with. the effere matters are retainted, ard they poison and deratere erery or:atu from the hain downward. Even apparenty insignificant orans have a far-leathing inHuence. 'The spleen aril bone marrow-cells atiect the development of blood globules. A small gland at the throat (thyroid) atiects the nerrous system, and a still smaller one at the base of the brain (pituitary) influences the growth of the limbs.

411a. hepent the experiment suggested in 390 a. Make lime water by placing a piece of quicklime in a bottle of pure water, shaking and setting aside to settle. "Ihen take a little of the elear liquid and with a syringe foree air through it. It will become only slightly turbid. Next take a tube and blow through this watel for a short time, when it will become white and opaque ly the formation of lime carbonate, owing to the union of carbon dioxid with the lime.

4li3u. The lung of any of the higher animals presents an enomous surface to the inspired air. To illustrate the extrat ordinary extent of breathing surface formed by this minute division of the lungs into microseopie saes, it may be stated that, in the horse, it reaches an area of 500 to soo square feet.

$41+a$. The heart of an ox, sheep, or other animal can be obtained at the slaughter house or of the butcher. Discorer

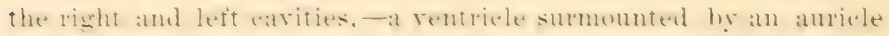
on each side, - the ralres around the opening leading fiom the

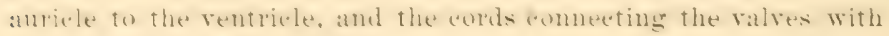
the immer side of the rentriele.

the When blond is shed in killing an animal or otherwise. olserve how the surfites layer saldually changes from the dark real to a lright erimson as it takes up the axyen from the air. $+18 a$. In the conveyance of oxygen in the blood the coloring matter of the red slobules (homoglobin) is the principle leazer. It eombines with oxygen loosely, and gives it up promptly at the demand of the carbon. The hright crimson color is due to the uniom of much oxygen with the coloring matter of the 
red blood globules, while the dirk red hue is eansed by the comparative absence of oxyen. The liquid elements of the blood (serum) can absorb and convey but little oxygen. In order to have free and healthy breathing, therefore, the blood must contain abundance of red ghlobules, and these must he well dereloped, containing a large amount of the red coloring matter. Ill health, lack of sunshine, and various diseases, which ratuse diminution of the real globules or of their coloringe matter, interfere with respiration and consequently with the healthy nutrition and function of the tissues of the animal.

4-2tar. Persons who desire at detailed ateeount of the physiology of domestic animals, may consult F. Smith's "Manual of Veterinary Physiology." Advice as to the treatment of animais is contained in Law's "Farmer's Veterinary Adviser." 


\section{Chapter IV \\ THE FEEDING OF THE ANIMAL}

H. H. WIVG

\section{Sources of Food of Animals}

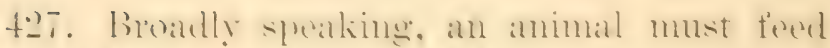

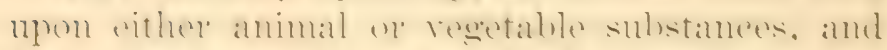

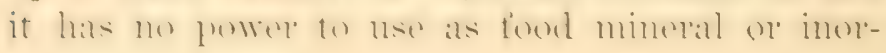
ganie substances.

4.'- Goy substamere whieh an animal may use

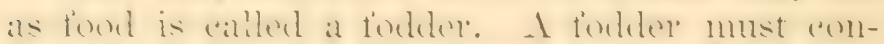
tain the substamess that alle nexpert for sustenather in sluch form that the anmal ean use theme and must not entain anything that is ingurions op poisonous to the animal.

\section{Hou the Animal Tises Food}

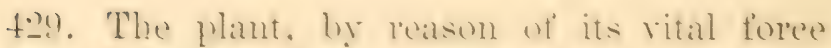
and with the alil of the merey of the sme transforms simple forms of matter inte more eomplex mes. and in so doing lowes or stores mp a part of the energy received. The animal, by means 
of its digrestive processes, tears down these substances, setting free the energy and transforming the matter into forms suitable to be incoryorated into animal tissue.

4:3). Before the matter of the fodrder can be used, it is necessary that the animal expener enenergy upon it during the proressose of digestion and assimilation. 'The profit of the fordere to the animal is represented by the diffrrences between the amomit of energy originally present in the forder and the anount of energy it is necessary for the animal to expend upon it in orrer to malse it available. Some substances requirs so great an expenditure of enerery by the animal to digest or martially digest them that they aro useless as forders, although they may eontain the proper compounds in moasurably poper proportions.

431. Fodder is used by the animal (1) as fuel to kees up the bodily heat, without which the vital processses cammot go on; (2) to repair the wastes of the varions tissues, oreans and fluids of the body; (3) to form new tissurs or organs, or adrl to those alrearly formed (repperebally in yomen animals); (4) to poroluer yomme; and (5) to lay up reserve stores in the form of fat or otherwise, to secrete various products, or to perform muscular labor Many of these peserves or products are useful to man, as milk, wool and regers.

432. In general, if the amount of food is 
insufficient it will be used for the first four purposes, approximately in the order named; and only after the needs of the amimal are fully supplied in these respects will food be used for the last purpose. The food used for the first four purposes is colled food of support or food of maintenance ; that used for the last purpose is food of production.

433. Not all of the food taken into the body eam be used lix the animal. 'The dientive fluids fail to act upon a palt of the food, and this passes out through the intestines as moligested solid "xcrement. It is only the food which is cligested that is of use to the animal.

tist. The proportion of food digested varies with the animal. One amimal may digest 80 per cent of the fool eatere; another, standing ley its side, efually healthy and epually vigorous and of similar age, mal digest less tham $f(0)$ pel cent.

tis). The amount digested varies with the food and with the different eomstituents in the food. Fome foods are almost wholly digested; of others less than ontefouth is digested. In any given forler, one comstituent may be readily and largely digestihle, while another is digested only with diffirulty and in a small amount. In general, of the food eaten only from one-half to twothilds is digested. 


\section{Composition of Fodders}

\section{3a. Classification}

436. Fodders are made up of a large number of substances, all of which are of more or less use to the animal, and each of which, to sonie extent, serves a definite purpose when user as food. While the number of separate compounds in fodders is very large, they fall into a few very distinct groups or classes, depending upon their composition and the purposes which they serve the animals. These "lasses are (it) water, (b) ash, ( $)$ protein, (d) carbohydrates, including fiber, $(e)$ fat.

\section{3b. Water}

437. Water is present in all forders without exception, lut the proportion is rery variable. Some roots and green fresh fodders orcasionally have as much as 90 per cent of water, whereas, in some of the kiln-dried by-products the perrentage of water may fall as low as 5 or 6 per rent. Ordinary air-dried fodder, as the grains, hay, straw, usually contains from 10 to 15 per cent of water.

438. The water in the fodder to a certain extent smplies the needs of the animal instead of water which is drunk. Animals cousuming a 
watery tood will nead to drink less water: but no fond contains so mude water that it cam les used hy the animall to supply its needs for both water and solid matters.

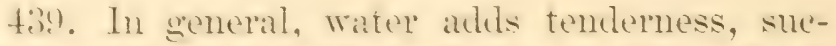
culence and palatability to fodelers. Green fresh fodilers are more palatible than the same fodclers Aried: and the palatahility of hay or othere dry foulere may be ineleased by soaking in water, or by steaming.

3c. Ash

4to. Ish is the small resiclue which is left when any animal or verestables matter is eompletely bumed. It is mineral matter obtained by the plitut from the soil $(1+\overline{7}, 1) \cdot 2)$, amel is eomfusted of very nearly the sime substances in both flants and animals. Fome alsh is fommd in all fialts of all plants and all amimals, and it is

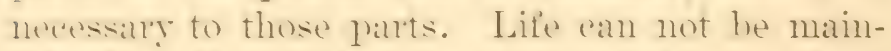
taimed or the vital processes carriol on without this ash.

41. In sentrial, the lloportion of ash is small, hett the bones of amimals and certain fiats of the plant, as the hark, contain consilerable ambunts. Tith searee an exeeption. the amount of ash present in ordinary fodders Is suthicient for the nowe of the animal. and, therefore, it need not be taken into account in 
making mp a lation of deroiding npom a forlder; simes no matter what is forl, it is alnost reptain 1hat the animal will find in it an abundant smpply of the propere mineral elements, with thes exception of common salt.

\section{Albuminoils}

+4.). The potein, or protrirls, ronstitutes a vory important group of folder constiturntis. While they ares of a complex and variesl resm-

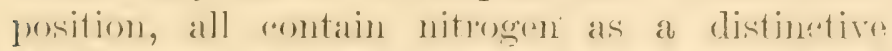
(onstituent, as wall as ratom, oxyongen and hyrloggrn, and usually sulfur and phosphorus. It is the nitrogen that grives to the members of this group thrir imprortanre as foor ( 370$)$.

44.). ()lganire aretivities ram not be matintained without nitrogen. It is an essential constituent of the living animal or vogetable cell, and no new growtl ran take place withont it; ronseruently it must he comstantly supplied in the food of both plant and animal. Nitrogen is not a constituent of the other groups of food plements, aud, therefore, the growth of the animal drpends in large measure on the supply of protein.

4t. While mores or less protein is foumel in noarly all forlures, its proportion is very variable, and in very many cases is less than is perpuierel hy the animal to sustain life or to make nsoful growth. Those forlolors that contain latge 
amounts of protein are manly found in the grains and othere concentrated foods that are relatively high-priest. Both these conditions make the problem of suecessful feeding laresty one of the suttiedent and exonomieal supply of albuminoids. If an insuttiedent amoment is furnisherl, the animal sutters in growth or prouluetions: if more than enough is supplied, costly waste ensues.

\section{3e. Carbohylutes}

4ti. By far the lateres part of the dry matter of codders is classed with the arbohydrates, the most familiar examples of which are suears, stalreh, exum and regertalle fiber (:371). Theses sulstameses contain earbon, oxyen, hydrogen-the two latter in the propreptions in which they are foumel in water. 'They entain no nitrogern.

4t6. By mion with oxyen in the lungs and

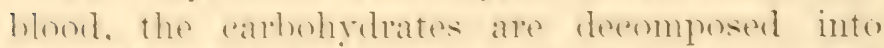

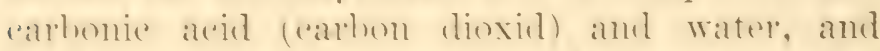
heat is evolved in preseisely the same way as muler ordinary ambustion in the air. They are thus the main soumes of heat to the animal. 'They are also a sompere of musenlar enerey, amb in most eases an impurtant sompere of tat in hoth tissue and product.

4ti. ()t the earhohylrates, fiber is much less rearlily acterl on by the digestive Huids, and often a larege part of it passes through the animal 
withont rhaners. For this reason it is often ronvenient to romsirler it in a colass hy itself. So far as it is used at all, it serves the same purpose as the other carbohydrates.

\section{3f. Fats}

4t6. The fats (:3710) of fordrove are used by the animal for mole the same jumpses as thr rarboleyllates. They contain only rarbon, oxy(x) and hyrlogen, hut proportionately mudl less oxyeren than the raphohydrates. For this reason they yield murle more eneregy when decomposerl or bumed, and are, therefore, of murh moles value to the animal than the earbohydrates.

4t.). 'The amount of "melæry yielderl hy differmet futs varies somewhat, but in seneral, it is about two and one-fourth times as much as that yeleler hy an erual weight of sugar ol stareh; and in reducing fat to its "starch equivalent" (for pmposes of eomparisom) this is the fartor comnonly employed. In ordinary fodders the percentage of fat is not large, ruming from about 3 to about 8 per rent of the air-dry substance.

\section{Feeding}

\section{4a. Nutritive ratio}

45) 0 . From what has alleady been said, it will be seen that the protein, carbohydrates and fats 
are the comstituents of the fodder that are of direet use to the animal. These are often eolleretirely spokem of as nutrients, amel the portion of them that is digestible as digestible nutrients.

4.i1. Since the protein (or albuminoids) is neressitry to growth and reproduction, and since the earbohyetrates and fiats are mainly nsed to produce heal and work and reserve stores of fiat, the lorpere relations of these constituents to one another in varrious fodder's and rations constitute an impertant part of the scienee and art of feeding. I ration is salil to be balaneed when these substanees exist in the propel proportion to one another for the purpose intended.

$45 \%$. It has heren found convenient to express the relation hetwern the protein and other constituents in the form of a ratio, known as the mutritive ratio. The mutritive ratio is the ratio of the dignstible protein to the digestible carbohydrates plus two and one-fourth times $(449)$ the digestilule fat, expressed in terms of unity or one of the protein.

t53. The nutritive ratio is found by adding to the digestible carbolychates two and one-fourth times the digestible fiat, and dividing by the digestible protein. It is expressed thus: Tutr. Ratio $1: 5.5$. It means that in some certain forlder or ration there is for a ach poumd of digestible protein or Hesh-forming nutrients, five and 
one-half jounds of digestible heat and fatforming elements. A ratio is said to be wide or narrow when the proportion of heat-forming nutrients is large or small in proportion to the protein. 'Thus, $1: 12$ is wider than $1: 7$.

45t. A certain proportion should exist betwern thes nitrogenous and non-nitrogenous nutrients of a ration. Animals that are growing rapirlly, that are hearing young, and that are jroducing wool, milk or eggs, require a more nitrogenous foorl than animals that are working, or fattening, or living without gain or loss of weight. For the latter, the nutritive ratio may be as wide as 1: 12 or $1: 14$; for the former, the nutritive ratio should be as narrow as 1:5 or 1:6.

4.5.). Formerly it was supposed that slightly differing mutritive ratios would make distinct differences in the effectiveness of a ration or the quality of the product; but it is now grenerally considered that the limits of variation in the nutritive ratio may be rather wirle without materially influencing the nutritive effect of the ration. Other conditions may mask the effect due to differences in the nutritive ratio.

456. One of the chief reasons for taking the nutritive ratio into consideration is that the protein may be economically used. Protein should be used for the formation of nitrogenous products in the animal. It may, however, be used as a 
source of heat, instead of the cheaper starch or sugar. This may oceur in any ration when the proportion of protein is in excess; but there is generally a too small proportion of protein.

457. By far the larger number of natural fodders are deficient in protein, and a chief task of the feeder is to furnish, from hy-products or otherwise, a sufficient amount of albuminoirs in the cheapest form. C'sually more motein can he nsed to arlvantage by the animal than is furnished to it.

\section{4b. Quantity of food required}

4.5. The quantity of food that an animal can profitably or economically use is rependent upon a variety of eiremmstances and conditions. In the first place, a certain amomit must go to the support of the body and the rital funetions. This is known as the food of maintenanee (4.32); and a ration calculated to keep an animal alive and in goorl health without gain or loss of body weight is caller a maintenance ration.

4.59. The amount of food required for support depends upon the size and somewhat upon the individuality of the animal. Small animals require more food in proportion to their weight than large ones. Average animals of the same class, however, are usually considered to require food in proportion to their body weight. In 
general, for horses and cattle, about 18 pounds per day of dry matter per 1,000 pounds live weight is required for maintenance.

460. It is from the food eaten in addition to that required for maintenance that the profit comes to the feerler. Hence, if an animal receires no more than enough to sustain life, it can prorluce no profit to its owner. Much less is there profit if an animal is allowed to lose in weight; for common experience has shown that when an animal is once allowed to suffer loss in weight, the loss is regained only at an increased expenditure of foor above what was originally required to produce it.

461. The amount of food that an animal can use profitably over and above that required for maintenance, depends upon the rapacity of the animal and the purpose of production. Most animals will make a return approximately in proportion to the food consumed, up to a rertain amount. Above that amount, the fool simply passes through the animal; or the rligestive apparatus becomes disordered and the animal refuses to eat. However, the capacity of different animals in this respect varies widely. $46^{2}$. Assume that six pounds per day per 1,000 pounds live weight is about the average amount of dry matter that an animal can profitably use above that resuired for support. It will 
be found that many animals can not profitably use more than three or fonr pounds, while others can use from ten to fiftern pomils, and an oceasional animal can profitably use a still larger amount. t(6.). 'The amomnt of fool that an animal can or will ent must not be confomeder with the amomit of fool that an animal can profitably nses. Mairy animils eall ant comstantly do pass through their bodies a considerable amount of food of which no use whaterere is made, and this, too, without interfering in any way with the general health, digestive functions, or aven with the appetite.

\section{4c. Feeding standards}

thit. Feeding standards show the amount and proportions of the various mutrients that have been found by experience to be hest adapted to the varions purposes. A few are given:

For Each 1,000 Pounds Live Weight per DaY.

\begin{tabular}{|c|c|c|c|c|}
\hline & $\begin{array}{c}\text { Dry } \\
\text { matter }\end{array}$ & $\begin{array}{c}\text { Digestible } \\
\text { protein }\end{array}$ & $\begin{array}{l}\text { Digestible } \\
\text { carbohydrates } \\
\text { and fat }\end{array}$ & $\begin{array}{l}\text { Nutritice } \\
\text { ratio }\end{array}$ \\
\hline Oxen (maintenance) & $.17 .5 \mathrm{lbs}$. & $0.7 \mathrm{lbs}$ & $8.15 \mathrm{lbs}$. & $1: 12$ \\
\hline Horses at work . . & .22 .56 & 1.86 & $11.8 \quad 6$ & $1: 7$ \\
\hline Milk coms .... & .24 & 2.56 & 12.9 & $1: 5.4$ \\
\hline Growing pigs (young) & 42 & 7.5 & 30. & $1: 4$ \\
\hline
\end{tabular}

465. In any given case, these or any standards may be advantageonsly raried to a considerable extent. The stundards are mere guiles. 
The skill of the feeder depends upon his success m finding out how far the individual requrements of his animals warrant a variation in the standard.

\section{4d. Bulk in the ration}

466. Aside from the amount of digestible nutrients and the nutritive ratio, the bulk of the ration is a matter of considerable importance. It has already been noted (4.33) that considerable portions of all the nutrients are not digested. C'onsequently, in every ration there is more or less material of which the animal makes no use, and which may be said to merely add to the bulk of the ration. Water and fiber are, above all other thing's, the substances which give bulk to a fodder or ration.

467. Fodders which rontain large amounts of either or both of these sulustances are said to be coarse or bulky ; forlders which have a minimum amount are said to be concentrater. If a ration is too bulky, the animal is umable to eat enough to obtain sufficient nutrients. ()n the other hand, a ration may be so concentrated that the proper amount of digestible nutrients do not sufficiently distend the digestive organs so that the gastric fluids may fully act. This is particularly the case with ruminants (382-38t, $367)$. 
468. When the ration is unduly bulky because of the presence of large amounts of fiber, it is often so umpalatable as not to be readily eaten. On the other hand, when water is the bulky element, the food is almost always very palatable, but the excess of water has a loosening and depleting effect upon the digestive system. Under ordinary conditions for ruminants, about two-thirds of the dry matter should be furnished in the form of coarse forage and onethird in concentrated food. For horses at work, not more than one-half should be coarse forage, while swine and poultry require the ration to be in a still more concentrated form.

\section{4e. Palatableness}

469. It is found to be profitable to provide, even at comsinlerahle expense, a certain amomnt of fresh green food for winter feeding, in the form of roots or like material, as a tonic to appetite and digestion. Silage is now popular.

470. The palatability of a fodder or ration, that is, the readiness or eagerness with which it is eaten,-is a matter of great importance. The mutritive effect of a ration often depends upon this factor alone. In general, anmals will make a hetter return from a ration that is palatable, even though it may not be ideally 
perfect according to the standard, than they will from a perfectly balanced ration that they do not like. In many cases the quality of palatability is inherent with the fodder, in others it is dne to the individual whim of the animal. It can only be determined for each forlder and each animal by actual trial.

\section{4f. Cooking and preparing the food}

471. Nost clomestic animals are able to eat and digest ordinary forage and srains in their natural state. But almost all follers may be lrepared in various ways so that mastication and digestion are farilitated or palatability in"reased. Only upon one point is there general agreement-that for most animals it is better that the cereal grains be gromm before feerling. As to the advantages and disadvantages of cutting or shredting coarse fodder, and soaking, steaming and cooking foods, opinion is very much divided.

472. There is probably some eronomy in consumption when (oolse fodders are cut or shredded. Palatability is often increased ly soaking, steaming or cooking; but cooking' renders albuminoids less digestible, and to that extent is a distinct disadvantage.

473. A certain amount of variety in the 
constituents of the ration is appreciated by all animals. If the ration is composed of several folders, these may be mixed in a miform mass and this mixtme fed continuously for long periods of time. This is particulary true of cattle and swine.

\section{SUGGESTIONS ON CHAPTER XV}

$437 \alpha$. By-products are secomdary products which result from the mamufacture of a given probluet. Thus, buttermilk and skimmed wilk are by-probluets of butter-making, whey of chensemaking, pomane of chler-making, bran of flour-making Many important by-products used in feeding animals result from the manufacture of breakfist cereals, the manufacture of glucose syrups, and the processes of brewing and distilling.

442a. 'The group takes its name from albumin, which is seen in its purest and most common form in the white of exg. The gluten or sticky purt of the wheat kernel, the casein or cheesy part of milk, and the muscular fibers of lean meat, are also faubliar examples of alluminoids. From the many forms they assume, they are often spotien of as protein compounds, or proteids. They are also often called nitrogenous substances (370).

443 . Tho albuminoids are necessitry to all the processes of growth and leproduction; anr since most animal products, as woul, flesh, exws aml risilk, contain large amounts of nitrogenous matter, the albuminoids are likewise essential to production as well as growth. When the members of this group are deromposed or hoken down, they give up heat, ame, therefore, may be used to keep the animal warm (372). It is not at all uncertain that they are not concerned in the formation and storing up of fat in the tissues and milk.

445a. The word earbohydrate (written also earbhydrate) means carbon-hylrate. The word hydrate signifies a substanco in which water combines with some other element: in the earbotydrates, this other element is carbon. In all the carbohydrates, 
the oxygen and hyllogen ate in the proportions in which they oceur in water, - two atoms of hydrogen to one of oxygen $\left(\mathrm{H}_{2} \mathrm{O}\right.$ is water. 130b). 'The carbohydrates are sometimes called amyloids, - that is, starch-like materials.

453a. The determination of the nutritive ratio is very simple. For example : clover hay of average quality contains say $7.4 \%$ of digestible protein, $11.7 \%$ of digestible fiber, $26.3 \%$ of digestible earbohydrates other than fiber, and $1.9 \%$ of digestible fat. Then $2 \frac{1}{4}$ times 1.9 is 4.3 ; to this is added 11.7 and 26.3 , making in all 42.3, or the stareh-equivalent of all the heat- and fat-forming nutrients. Then 42.3 divided by 7.4 equals 5.7. The nutritive ratio of clover hay is, therefore, $1: 5.7$.

458 . The results obtained from any food depend in large measure upon the housing and care which the animal re-

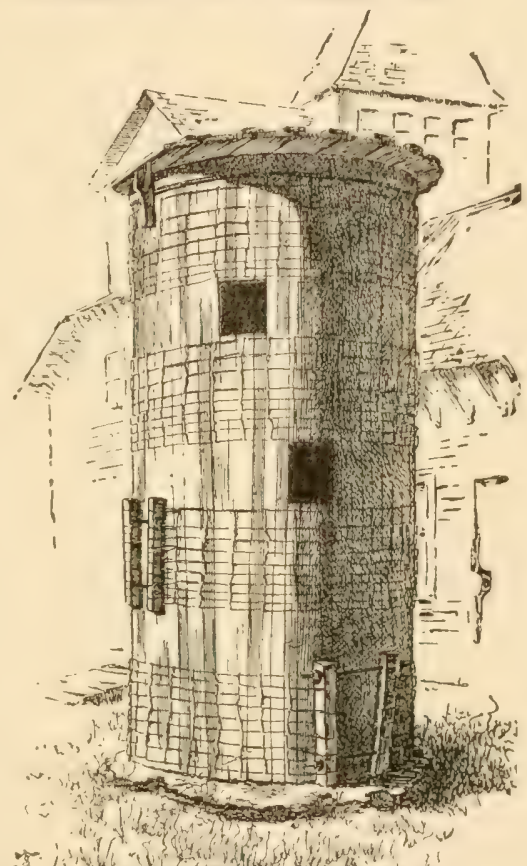

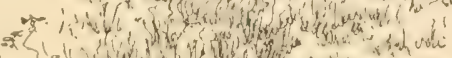

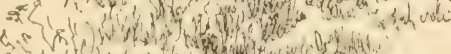

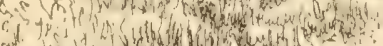

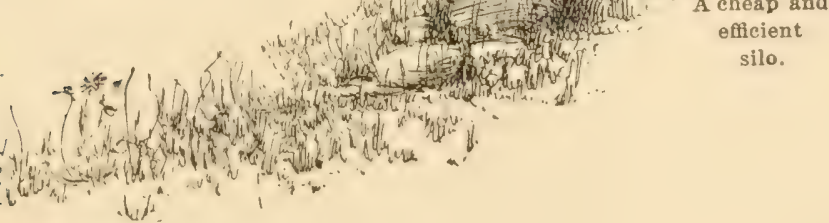


veives. Stock should have warm, airy, light, clean, sweet stahles (see Fig. 32, p. 86); and in cold weather the drinking water should be slightly warmed. Stock should not be turned ont on cold and blustery days, and a covered yard (Fig. 30) should be provided. T'o endeavor to secure good results in feeding animals which are cold and uncomfortahle is like trying to heat a Louse with the windows open.

469 . On domestic animals while in a wild state depended for existence almost wholly upon green forage. This trait survives in the fact that in many cases animals will make a larger return for a given amount of untrients when given green and fresh food than they will for the sime nutrients when dry.

469b. Silage (not ensilage) is forage preserved in a creen and suceulent condition. It is preserved by being kept in a tight receptacle, from which air and germs are exclucled as much as possible. This recertacle is called a silo. Maize (corm-fodder) is the most popular silage material. It is cut into lengths of an inch or two and immediately placed in the silo, being firmly tramped and compated, and the mass then covered with straw, hay, boards, or othex material. Circular silos are best because the material settles evenly all around. Fig. 90 shows a very economical silo at Cornell University. It is 12 feet in diameter and 24 feet high, and rests on a cement floor. It is male of lumber 24 fect long, 6 inches wille and 2 inches thick, the edges not bevelled. The pieces are held together by sections of woven fence-wire, drawn together by means of serew clamps. There is no framerork. Silage is useful as a part of the daily ration, but it is easy to feed it to excess. Forty pounds a day is usually sufficient for a cow in full milk.

473a. Persons who desire to pursue these subjects further should consult Henry's "Feeds and Feeding," and Armsby's "Mauual of Cattle Fteding;" also Jordan's "Feedng of Animals." 


\section{Chapter XVI}

\section{THE MANAGEMENT OF STOCK}

\section{P. ROBERTS}

\section{The Breeding of Stock}

1a. What is meant by breeding

47t. Animals grow old and die, or they are slaughtered for food. Other animals are born and take their places. Not only is a new animal born, but every pair of anmals is able to produce more than two: that is, the total numbel of animals increases. This birth and multiplication is known as propagation.

475. But it is not enough that new animals and more of them shall appear: these new animals must be desirable. They must have "ertain attributes or characters which make them valuable. In order that these desirable qualities shall arise, the stockman selects certain animals to propagate the race; and this control of the kind of offspring which shall appear is known as breeding.

476. Breeding may have t,wo objects: to 
maintain or reproduce the given type or breed; to produce a new type or breed. One may have small red cows, and desire to produce others like them, or with some improvement on the same lines; or he may wish from these animals to produce iarge red cows. In the former case, he maintains his types in the latter, he produces a new type.

47. A breed is a general race or type which reproduces itself more or less closely. It is analagons to a variety in plants. Among cattle, there are such breeds as short-horus, Jerseys, Deroms, Holsteins; among fowls, such as Bantans, Plymouth Rocks, Wyandottes, Shanghais. 'The person who guides and controls the propagation of animals is known as a breeder.

\section{The mental ideal}

tris. The first principles in breeding is to know what qualities one wants to secure. The bredere must have a distinet ideal in mind.

479. Nany ideals are impracticalble. In order to be practicable or useful, the ideal must be governed ly two fartors: the person must know the characteristics of the class of animals with which he is working; he must know which qualities are most likely to be "arried over to 
the offspring, or be perpetuated. Both of these factors are determined by experience.

480. The ideal type of animal varies with the uses to which the animal is to be put and with the breed. The points of merit in a dairy cow (one which is raised chiefly for the production of milk) are unlike the points in an ideal beef animal. The points in an ideal Short-horn are unlike those in an ideal Ayrshire.

481. Animals are judged by their general form, the texture of hide and hair, framework or bony structure, their motions, and dispositions, their performance and their products.

\section{1c. How to attain the ideal}

48:. Having leamer what the ideal animal should be, the breeder strives to secure that ideal by breeding only from those animals which most nearly approach the ideal.

483. Animals vary in their power to transmit their own features to their offspring. Some animals, withont any visible cause, possess the power of transmitting their own characteristics to an unusual degree. Such animals are said to be prepotent. Inferior animals may be prepotent, as well as superior ones. It is important, then, to discover beforehand if an animal is prepotent, or is what stockmen call a "good 
breeder;" although prepotency ran be positively known only by the characeter of the offerpring.

48t. The following are more or less rertain inclications of prepoteney: the eyes are bright, wirle open, alert, fairly wide apart and somewhat protruling, or the reverse of sunken. The hair is fine amd soft, the skin neither thick and leathery nor too thin or "papery, nor of flabby structure. The bones are of moderate size and have the apprallane of being fine grained and strong, as indieated hy head, limbs, feet and horns. Such animals are usmally symmetrieal, although they may not le fat. In of all their movements they are vigorons, alert and powerful and, above all, courageous.

485. Now and then a "sport" appears, - an animal which has some new or strange feature, something that we have rarely or never seen before in that breed (as a hornless or muley animal amonest normally hormed animals). Surh oceasional characters are usually not easily perpetuated, thomeh sports have heen the origin of mamy stable types, esprocially amome plants. Permanent improvement is more likely to be seculed by stow, small, steady augmentation, not by leaps and bounds.

486. The longer any line of anmals is bred to a single ideal or stamelard, the more miform the animals bereme. The breed or the family 
beromes "fixed." The record of this long line of breeding is known as the pedigree. The longer the pedigree, the greater is the likelihoorl that the animal will reproduce its characters; that is, characteristios which have been long present are more potent than those which are resently aropuired. IInoer, a long perligree shonld indieate more value than a short prexligree.

487. For the general farmer, it is unwise to buy a herl of pure-bloor stork, mnless the olject is to breed pure-bloor stock for sale. The breeding of pure-blood animals is a business by itself, and few persons are competent to sueceed in it. But every fammer can greatly improve his stock, if he starts with and constantly uses a cood pureblood malr mated with goor native females. From the gradres so producerl improvement will be rapirl and sure if the poorest are constantly sold and only the best bred from.

\section{Where Storli-raising Is Advisable}

489. Having now ensiderest some of the principles involverl in securing good stock, we may next infuire in what resions and under what ronditions it can he raised fortitably. Live-store raising is partionlarly arlvantageons on the cheap, moneroppere and uncultivable lands of the Wrest and south. In those reerions, storek 
must depend largely or entirely on the natural forage, which is sometimes good and sometimes extremely poor and meacer. It may require ten to twenty acres to support a single cow or steer for a year. If the "ranges" is eaten off closely during the summer, the amimals perish in the winter. In the dry and nearly snowless districts of the West, amimals may subsist in the winter on the mature deal grasses. Since the rainfall is light, theses matured crasses, or natural hay, retain most of their nutrient qualities.

489. In narrow, sheltered northern valleys surrounded by grass-covered, rolling hillsides, where the cereals cammot be raised to advantage, live-stock finds eongenial surromelings. In such regions, for many years, was the center and home of the dairy industries. Within the last twenty years the areas in which hutter, cheese and milk have been produred in large quantities for eity consmuption and export have become greatly enlarged and multiplied; and many whole farms, formerly used for the production of the cereals, especially of maize, are now conNucted as dairy farms.

490. On high-pricerl land near the markets, comparatively little live-stock will be kept, since the manures necessary to keep the soil fairly prodictive and filled with humus can be easily brought from the eities. The teams which 
transport the products to the markets often return loaded with the refuse of the city stables. 'There is little opportunity for the production of live-stock on the market-garden farm. Where intensive agriculture (111 $a$ ) is carried on, a few animals to consume the refuse, in addition to the "work stock," may be kept to ardvantage. swine are often a useful adjunct to marketgarden farms.

491. But perhaps the place above all others where live-stock fimds the best conditions, and where it is most likely to be improved from generation to generation, is npon the rich, level farms which are adapted to many kinds of crops. Lands which are caprable of producing cereals, grassess, fruits, vegetables, flowers and animals should be prized highly. (On such lands is offered the erreatest opportunity for the highest agriculture. Diversified agriculture, with one or two somewhat specialized ropse, learls to steady and rertain income, gives opportunity for fumishing entinuous employment for both men and teams, and in all ways tends to economy of time and effort $(354 a)$.

\section{How Huch Stock May Be Kept}

492. Cheap transportation, refrigerator cars, and the silo, have made it possible to produce? 
and semd dairy produres to marlict from distriets fill removerel from the eneall dities and the seaboalde at a protit. On the rieh pratries, wheresere maize will thomish, one thonsand

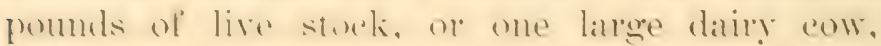

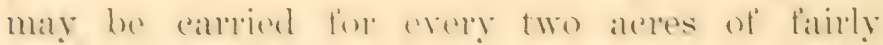
grood alrable limel. In some eases, some extral comentrated fords maly be required, it the animils are kept up to their full capaleity for growth and production.

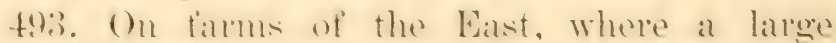
pereentage of the limd must be deroted to prermament pasture bramse it is sterp and stony, one animal of one thousand pomids to two aleress

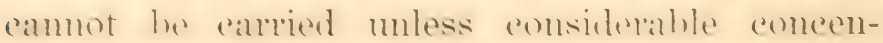
trated food is purchised.

t? 4 . There atre two methods respereting the numblen of andmals to be kiegt on a fiam. (Ine

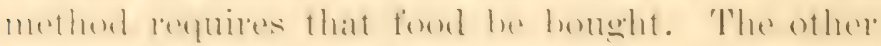

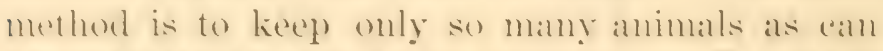
be maintained by home pesomeress. On lands naturally lertiles, and on these whieh have been

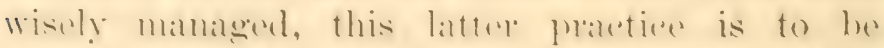
commemeded. It maty hes silil, howerere, that if the stockman eam sereme incerealsed profits by risking something for extra food, he shomld take anvintage of it; hut most farmels han hetter not assume many risks.

495. We may now spreali of the pratetice of 


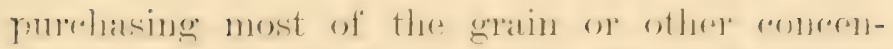

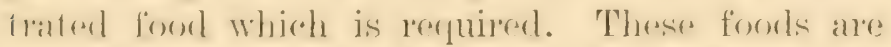
mostly by-pordurts (487a), suroh as bran, oil-

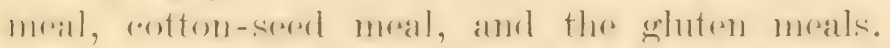

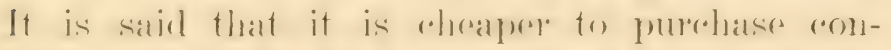

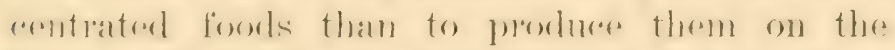
finm, and mueh stress is laid on the resultant plantfond or mammes which is serourer from feeding these products.

tom. A ton of wheat hran rontains the following amounts of potential plant-food in every thousand pounds:

$$
\begin{aligned}
& 26.7 \mathrm{lbs} \text {. nitrogen } \\
& 28.9 \text { " phospboric acid } \\
& 16.1 \text { " potash }
\end{aligned}
$$

This would serem to inrlicate that a thousand poumels of bran would be worth, for manurial purposes, \$5.57, or \$11.14 lel ton-compunng the nitrogens at 12 rents, phosphorice acid at 6 "ronts amel the potash at 4 cents per pound.

497. If ther hame is forl to mileh rows, it is estimated that not less tham 5() pre rent of the plant-food constiturents of the fool will be found in the mamme. If this he so, then the manure which is the result of fexding one thousand pounds of bran would he worth $\$ 2.79$, or from feeding a ton of hran, \$.5.5. If the bran be ferl to animals that noither gain nor lose, and are not producing milk or other products, then 
nearly all of the manurial constituents of the food are found in the excrements.

498. This practice of purchasing fool would appear to be wise on a farm poorly supplied with plant-food. It may be assumed that the increase in growth, or the products secured from the animals which consume these purchased foods, would equal or exceed the cost of such foods. If so, the value of the excrements would be clear additional profit.

499. In practice, howevers, it is found that the purchase of these supplemental foods becomes necessary largely hecause a wise nse has not been made of the land. If need of these purchased foods arises because but a half rop is secured instead of a full one, then greater attention should be given to making the land more productive. In many cases, the purchased foods are required hecause the production of grasses and the other forage plants has been neglected. Full crops and wisely purchased concentrated foods lead directly to the improvement of animals and land, and, therefore, to permanent prosperity.

500. When the coarser products are used for food and bedding, and a goodly portion of the grains are fed at home, it is possible, with care, to return to the fields three-fourths of all the plant-food which is removed from the fields 
to the barns in the crops. The ease with which a farm may be maintained on a high plane of productiveness when animals are made prominent, and the difficulty of maintaining high productivity when they are wanting, should emphasize the part which the animal plays in securing the best results.

\section{4a. Housing}

\section{The Care of Stock}

501. Every effort should be exerted to make the animals comfortable. Otherwise, they camot. to their best. Animals, like people, are most useful when they are happy. Provide them good quarters. As to the style and kind of barns, it matters little so long as the desired results are secured.

502. Animals need much air. A single row

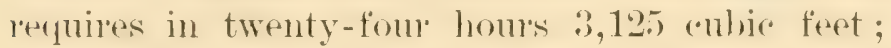
that is, all of the air which would be contained in a box-stall about 18 feet by $17 \%$ foest by 10 feet, if she has a full supply. As a matter of practice, howerer, a cow is allowed about 400) cubic feet of air. Twice as much air space should be provided in the horse stable as in the cow stable.

50.3. In the barn, free rireulation of air is restrivered; therefore, provision should he mante for ventilation. Large amounts of air introduced 
at few points create dangerous drafts. Air should be taken into and remored fiom the stable in many small streams. If the stable is over-ventilated, it may hecome too cold. If at least one cubic foot of air space is allowed in the stable for each pound of live animal kept in it, the air will not have to be changed so often as when the anmals are so crowded,-as is often the case, - that only one-half to onefourth as much air sparce is provided.

504. A balrn with a wall roughly boarded, both inside and outside, and the space filled with straw, furnishes nearly ideal conditions, since the air will be strained gently through the straw. This rentilation should be supplemented by a few small, easily controlled openings. Stakles should not be liept above 50 degrees nor tiall below 32 degrees, for any considerable length of time.

50.5. Abundant provision should be made for the ingress of light. It is best if the light is admitted at the roar of the animal, espereially for horses. Provision should also be made for temporarily storing the excrements, both to keel' the stable clean and to prevent loss of the valuable constituents of the manures. No excrements shonld be thrown ont of the windows or doors of the stable into the open weather', where they form a nuisance and ale wasted $(120), 120 a)$. 


\section{4b. Water}

506. All nutriment is carried into the systeni, and through it, by means of water. Since water is the universal carrier, it should ever be present in the animal tissues in quantities sufficient to accomplish the desired results. Animals should have water at least twice a day.

507. Animals ferl a narrow ration (453) require more water than those which are fed i wide ration. A cow in milk may require from fifty to eighty pounds of water daily. If the water is freezing cold, she will not drink freely and the production of milk will be reduced. Moreover, the water must be raised to the temperature of the body by the heat generater in the animal. This may require a part of the energy of the food which might otherwise have been turned to some useful purpose. If water at a temperature of about $60^{\circ} \mathrm{F}$. is provided for the stock in cold weather, the animals will not only enjoy it, but will not require as much food as when compelled to drink water near the frexzing point. In large herds, coal may well he substituted for meal in heating the drinking water.

\section{4c. Food}

508. So many varieties of acceptable cattle foods can be secured cheaply in America, that 
full opportunity is offered for selereting those which give promise of producing the particular results desimed in any given rase. Animals which are used rontinuonsly at hard work recpuire a wide or atrbonaceons ration to supply eneley. Yomme animals do best on a nampow or nitrogenous ration. Mileh rows do best on intermediate rations. Cold stables imply a wide ration; warm stables, narrow rations. The food of yomme herlororous animals, of those that work, and of eows in milk, may be made up of about one promed of erains or other concentrated foods to three pounds of roughage.

50). 'The amomint of the ration and the time of fereding should be woverned adeording to the chatratere and hathits of the animal. Horses should be feed moles often than cattle and sherele, since their stomalehs are relatively small. Horses are inclined to eat at night. Cattle, sheepe and swine selelom eat after dark.

510. 'The ration for any one meal should not bes so liberal as to injures the appetite for the me that follows. Regularity in time of feeding, and skill in presenting the food in an appetizing form, are prime factors of success.

\section{SUGGESTIONS ON CHAPTER XVI}

479 . 'I'he breeder must know the names of the varous parts of the animal. 'The parts of a dairy sow are designated! 
in Fig. 91, which represents a "typieal Ifolstein-Friesian cow:" 1, head ; 2 , forehead ; 3 , eyes ; 4 , faco ; 5 , muzzle ; 6 , ear ; 7 , horn ; 8 , neek; 9 , throat ; 10 , shoulder ; 11 , shoulder tops, or withers ; 12 , chest ; 13 , crops ; 14 , chine ; 15 , back ; 16 , loin ; 17 , hip or hook; 18 , rump; 19 , thurl or pin-bone ; 20 , quarter ; 21, thigh; 22 , hock; 23 , leg; 24 , forearm; 25 , hoof ; 26 , fore-

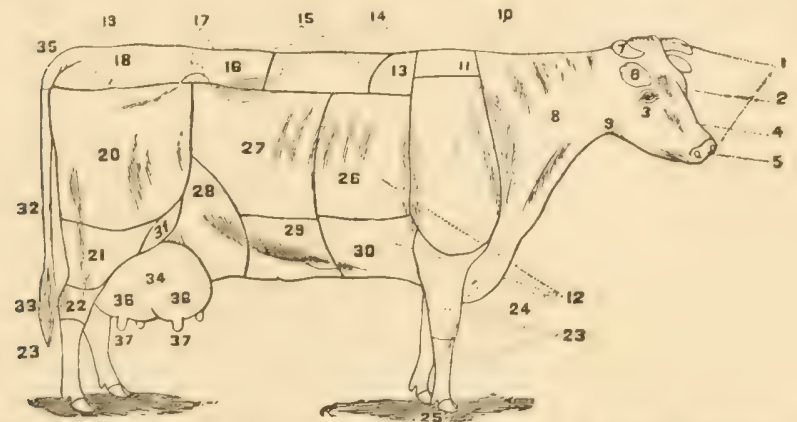

Fig. (1). Inagram to show the parts of a dairy esw to which distinctive names have been given.

ribs ; 27 , back-ribs ; 28 , flank ; 29 , belly ; 30 , fore-flank ; 31 , stifle ; 32 , tail ; 33 , switeh ; 34 , udder ; 35 , setting of tail ; 36 , quarters of udder; 37 , teats. The dewlap is the flap of the throat below 9. The escutcheon is the part surrounding the udder behind, on which the hair grows upwards.

$480 \mathrm{c}$. Following is the ideal of a dairy cow (compare Fig. 92): The cow should have a small head, a large muzzle and mouth, a rlean-cut nowe or fiace, that is, one free from fleshy growth, a straight or dishing forehead, bright prominent eyes, and at thin, long neek and noderate-sized horns. She may be from one to two inches lower at the shoulders than at the hips. Her seneral form, when looked at from the side, should be werke-shape, and the same shape should be apparent when viewed from the rear. The shoulders may be thin, lean and bony ; the batek rather long and rugged ; the loin fatrly broad, but not foo loroad, or the animal will tend to put on beef. The 
hip should bo thrown woll shead, which grves a longe, powertul hind quarter. 'The thighs, of necessity, are thin; the thank woll up: the hind leg, usually, quite arooked, stud the tail long. If the tail be lomer, it. is an indieation that the rertebre of the back bone ste somewhat loosely united, which is an indiention of grood milking qualities. 'l'he pony-built, smooth-made, shortbodied, rotund cow is seldom a grood milker. The teats should

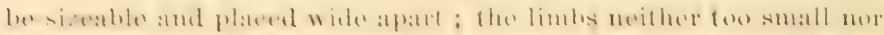

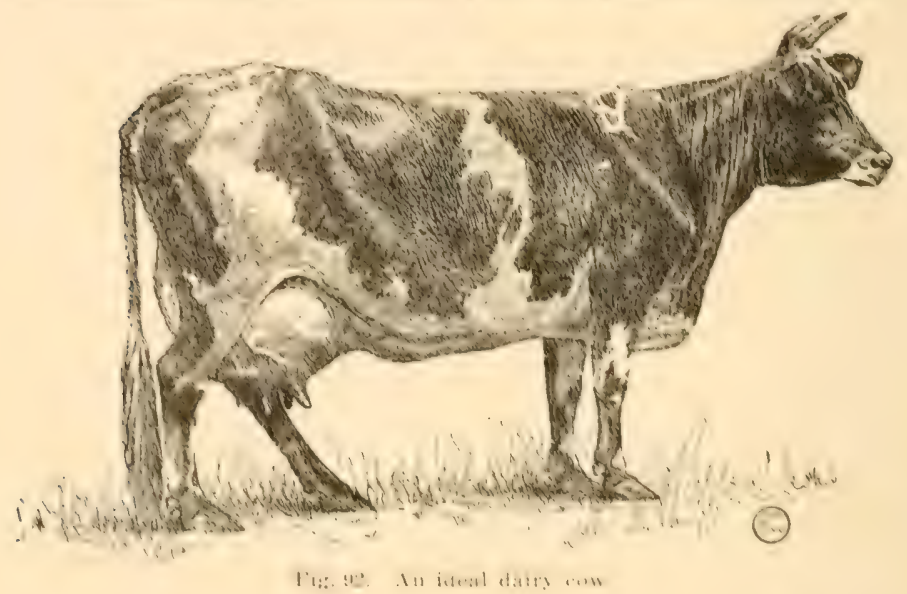

too large. The udder should not ho very pendent or loose, and should extend well to the rear, also well to the front, and should have a boad and tirm setting on the abemen. The animal should havo a rugred, rather lean, lout not a dolieato sppesamese. All animals, exerpt those liept for speed, should have rather short limbs, as this indicates, to some extent, eonstitution and power. It will bo notioed (lig. !) that the milk veins, which extend from the uddere forwand on the abdomen, are latige and prominent. 'Whese indiente that the eow is a great milkere or, in other words, that an ample supply of blood has been furnished to the udder by the arteries, and hence a laree amount of blood must 
be roturned through thes veins. In time, the veins onlarges in ordere to make room for the roturn of the blood from the wader. In some of the better milking strains, these large veins are inhorited, and can bo soun and folt on young animals which have nover given milk.

4806. Contrast the ideal points of tho beof animal. 'l'his animal, like the mileh animal, shonld havo a small head and horus, and bo light in tho throat-lateh. If tho neck, legs and bail bo removed from the beot animal, tho body is almost a perfeet parallologram. The neck is short and very heary where it is set onto the shoulder, the back straight, thighs built well out at the rear, and thick. 'The body of the animal is moro rounded, the short rilss or Join is broad, the flank is well down, the shoulders are heavy and well covered with meat, the floor of the chest broud, which places the front loges wide apart. The whole structure of tho animal indicates slowness of motion, quiotnoss, and a disposition to liy on flosh and fat, or in other words, to bo selfish. No milk voins appear, tho tail is shorter than tho mileh cow's, arsd the receptaclo for milk small. $\Lambda$ s a rulo, tho beot animal las a softer and more velvety lonch than the dairy unimal, sines tho one is usually fit and the other lean. A strong, low brisket (the hanging part between tho fore legs is desired, not because tho flesh of it is good, for it is quite inferior, but bescauses it is an outward indication of superior feeding qualities. It will be noticed that in tho dary now the briskot is jrominent, but thin. It indieates good feeding qualities: that is, a good appotito and powor to digost and assimilate food. 'True, it seems to have no direct connection with tho production of milk, but animals which aro markedly

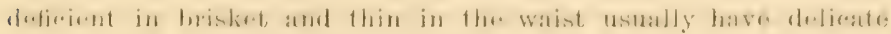
constiutions and precarious appotites.

480c. A moderately thick, elastic skin and soft, volvety hair ares mueh desired, not only in eattlo but in horses. $\Lambda$ thin or

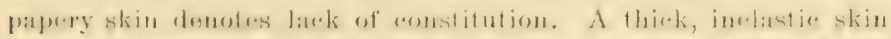

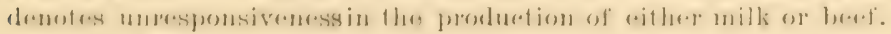

480d. With theso ideals for cattle, compare some of tho points of excellonce in a trotling horse: The front legre have 
a long, low, lhythmice motion when the animal is alert, while the hind quaters aro lowered and widened, and the hind legs, with their wide, all-embracing sweep, show how and where the great. propelling powery is located.

481a. 'The seoring of animals is a matter of ideals. 'The person assumes that at total of 100 points represents the perfect animal, each pat or quality beingr represented by a certain figure. Any animal may then be judged (as at a fair) by this standare or score. Drefinite seores have heen adopted by various breeders' assomiations, colleges, ete. For illust ration, twoseores aro now grvou.

$481 \%$. Following is the seore for a dary eow used by the College of Agrieulfure, Cornell University:

GENERTI, ATPFARANCE: :

Weight, estimated ...........lus. a atual...........lbs.

Form, wodgro shapo as viowed from front, side and toj)..

Qualit", hotir fono, soft ; skin mellow, loose, medium thickmoss, serretion yellow; bann vlean.......... 8

Constifution, vigorous, not inclined to beefiness......... \&

HNAl AN1) NECK :

Muzzle, clesm (nut; mouth largo ; nostrils largo........ I 1

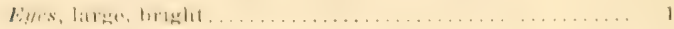

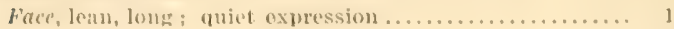

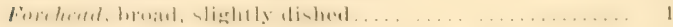

Ears, medium size : yellow inside, fise texture........ I

Neck, fine, melinm length ; throat cloan: light dewlap.. \&

FOIK AND HINI Q QUARTELS:

Withers, le:tn, thin........................ I

shoulders, light, oblique, .... ... ............

Ilips, fitr upart; level between henks ..............

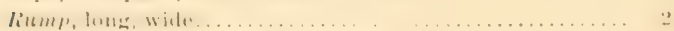

l'in-bones or therls, high, wide apat ..............

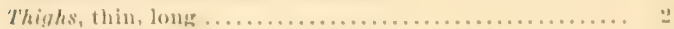

Leus, straght, short ; shank tino................ 1

Tail, long, slim ; tine switeh..................... 1

1301)Y :

Chest, doep, low : wirth larea $\ldots \ldots \ldots \ldots \ldots \ldots \ldots \ldots \ldots$ \&

libs, broad, well sprumg, long, whilo apart; largo stomach, is

Buck, lean, struight, chine ojen ................ ;

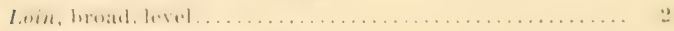

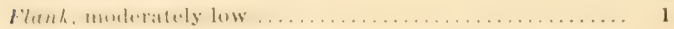

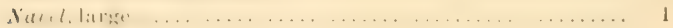




\section{Milk-sfereting Oraans :}

Udder, long, attached high and full behind, extending far in frout and full: qualtw.

Udder, capacious, tlexible, with loose, pliable skin covered with short, fine hitir ....................... 13

Truts, lanke, weniy blaced......................... ।

Milk veins, large, tortuous, large milk wells ........... 6

Escutcheon, sprealing over thighs, extending high and wide ; lave lhigh wals.......................

'Total ................................ 100

481c. 'The score for a beef steer as used by the Department of Agriculture, University of Wisconsin, is the following :

General Aptearance:

Weight, estimated ............... Ibs.; according to age.. 6

Form, straight top-line and under-line; deep, broad, low, set stylish............................. 8

Qualit, firm handling: hair fine; pliable skin ; dense bone; evenly fleshed........................ 8

Temprument, quiet ........................... i

\section{HEAD AND NHCK :}

Muzzle, mouth large; lips thin; nostrils large........ I

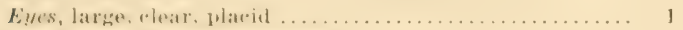

Fare, short : quiet expression .................... 1

Foreherel, hroad, full .......................... 1

Ears, medium size, tine texture .................. 1

Wrek, thick, slurt : throat eleath ..................

\section{FORE QUARTERS :}

Shumlder linin, tull....................... 3

Shoulder, covered with flesh, compact on top; snug.... 4

Brishet, atvamed, lireast widr...................

Derlup, skin not too loose and dronping .............. 1

Legs, straight, short; arm full; slank tine, smooth .... 3

\section{BonY :}

Chest, full, deep, wide; girth large ; crols tull......... 8

líbs, long, arehed, thickly lleshed................... 6

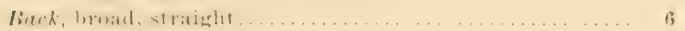

I,oin, thick, loroat ...............................

Flank, pnll, aven with under-line................... \& 
HIND QUARTERS :

Hips, smoothly corered; distance apart in proportion with other parts ........................... 4

kump, long, even, wide, tail head smooth, not patchy.... 5

Pin-bones, not prominent, far apart ................ 3

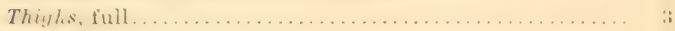

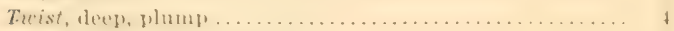

Purse, full, indicating tleshiness .................. "

Legs, straight, short, shank fine, smooth............

Tutal ................................ 10i

486 $\alpha$. A correct, long pedigree is also evidence that no crosses outside of the breed have been made within the time covered by the record. Then the longer the pedigrese, the longer the time which has elapsed since the hreed was formed. Many breeds, as Shropshires, Rerkshires and the like, start from mixedblood animals more or less remote. The term "pure breed" simply means that a breed of animals has been bred so long within the variety that a fair degree of uniformity in all leading characteristics has been secured, and power acquired to transmit the leading qualities with a fair degreo of certainty.

$48 \pi \%$. If the farmer has a dairy, let him resolve to breed from no animal which gives less than 4,000 pounds of milk a year. Animals which give less than this amount are often kept at a loss, and they should be disposed of at once. Every dairyman should also test his milk for richness, by means of the Babeock test. Read Wing's "Milk and Its Products, for instruction on the Babcock milk test, and other matters of dairying.

491a. There is a marked tendeney for farmers to run too mueh to one thing, following the lestl of some prerson who has been suecessful in a particular line. In some loealities in the East, especially in the great grape and hop districts, the ill efferets of speedialized agrienlture are often seen. When grapes and hops bring prias which barely pay for pleking them, - and this not infrequently oceurs, - the farmer becomes discouraged, necrlects his plantations, and when prices rise to the point where profits should be received, the yield per acre falls so low by 
reason of the nerelest that no financial recovery is possible. In these districts live stock should play an important part.

4916. It is found that wherever the areas of special crops are restricted, and rotation and mixed husbandry are not serionsly disturberl, fatir profits are realized every year, and the average yiclis of grapes or hops per acre are much above the average of the latge plantations. Syestialization is seren to havet a markerl, deleterious efferet on the youth of the distriefs where it is practiced in a large way, and often on tno productivity of the soil as well. The introduction of domestic animals in considerable numbers temels to change all this. Moreover, the elevating affert of eoming into immediate contart with animal life, especially on the youner, should be molerstomd and prizerl.

$500 a$. A crop of 50 bushels of maize per acre, and the aceompanying stalks, contains alwul 64 pomnds of nitrogen, 24 poumbs of phosphoris areid and 36 jounds of potash. If, when fed to animals, only one-half of the ylant-food removed by the "rop is roturmed, then but 32 promils of nitrogen, 12 poumls of phosphoric arid, and 18 pommls of potash will le lost from couch acre. When clover is in the rotation, it will restore most of this lost nitrogen. The plant precedes the animal. He who has mastered the art of producing plants successfully has learned more than half of agriculture.

500b. Animals play such an important part in maintaining the productivity of the latur that he who farms without giving them a prominent plare should be able to furvish good reasons for so doing.

5]fu. Remumber that thoughtful care, solicitude, love for the animal, amel timely attention to the many details, play an important part in animal industry. That which is gained by superior bresting, food and comfortable buildings may he partly lost if kimbursis is wanting. "Speak to the animals as you should to a lady, kindly." 


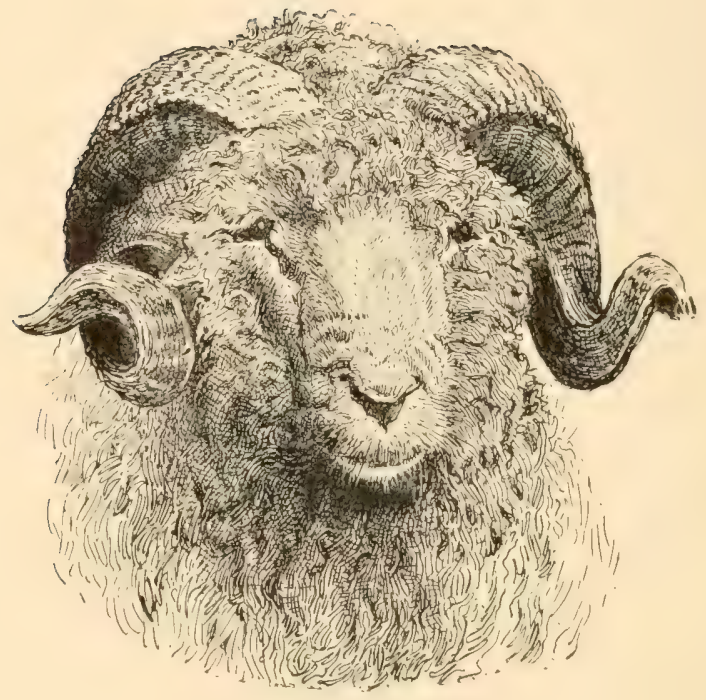

Fig. 93. Tho heal of the flock. 


\section{GLOSSARY}

\section{(Numbers refer to Paragraphs.)}

Asthetic. Appealing to the faculties of taste, as of color, music.

Agriculture. Farming. 1, 1a.

Albumin. A nitrogenous organic compound, present in both plauts and animals. $370,442 a$.

Aliment. Food.

Alimentary canal. The digestive ehannel or tract. 377 .

Ameliorate. To improve.

Amenable. Open to, liable to : a loose soil is amenabie to the action of air, but a very hard soil is not.

Amendment. A substance which influences the texture rather than the plant-food of the soil. 58.

Anmual. A plant which lives only one year. Beans and pigweeds are examples.

Antiseptic. A substance which kills germs or microbes. $284 a, 387 a$.

Available. Capable of being used; usable, $43 b$.

Axil. Angle above the junction of a leaf-stalk, flower-stalk, or branch with its parent stem.

Biennial. A plant which lives two years. It usually blooms and seeds the second year. Mulleins and parsnips are examples.

Botany. Knowledge and science of plants. 16.

Breaking down. Said of hard soils when they become mellow and crumbly.

Budding. A kind of grafting, in which the cion or bud is very short, and inserted under the bark or on the wood of the stock (not into the wood).

By-product. A product incidentally resulting from the manufacture of something else. $437 a, 495$.

Callus. The healing tissue on a wound. 234.

Cupillary. Hair-like. Said of very thin or tine chamuels, especially those in which water mores by the force of capillary attraction.

Carbohydrate. An organic or carbon compound, in which hydrogen and oxygen occur in the same proportions as they do in water. מugar, starch, woody tiber are carbohydrates: 197a: 
Carbon. A gas, C, existing in small quantities in the atmosphere; aiso in a solid form in charcoal and the diamond.

Carbon dioxid. A gas, $\mathrm{CO}_{2}$; carbonic acid gas.

Carnivorous. Feeding on llesh. 174.

Castin. Milk, curd, the chief albuminoid of milk. It is the main constituent of cheese. 370 .

Catch-crop. A crop grown between plants of a regular crop, in the interval of time between resular crops, 109.

Cereal. A grain belonging to the grass family, as wheat, maize, rice, oats, barley, rye.

Chemistry. 'That science which treats of composition of matter. 18.

Chlorophyll. The green matter in plants. 198, 198a.

Cion. A part of a plant inserted in a plant, with the intention that it shall grow. 236.

Climatology. Knowledge and science of elimate. It includes the scienco of weather (local climate) or meteorology. 19.

Coagulate. To curdle; as of milk.

Coldframe. A glass-covered box or frame which is heated by the sun, and in which plants are grown or kept.

Coming true. Reproducing the variety, 215a, 2\%7.

Comminute. To break up, fine, pulverize. $29 a$.

Compost. Rotted organic matter. $34 \alpha$.

Conservation. Saving. 8:3.

Cocer-crop. A catch-crop which is lesigned to cover the soil in fall, winter and early spring. $109,116$.

Cultivator. An implement which prepares the surface of the ground by turning it or lifting it. The spring-tooth harrow is really a cultirator.

Cutting. A part of a plant iuserted in soil or other medium with the intention that it shall grow aud make another plant; slip. 231.

Dehorning. Removing the horns from animals. I $20 \alpha$.

Dependent. Depending on other means than its own, as on the conditions in which it lives. 182.

Denude. To strip, to make bare, to wash away. $26 b$.

Dormant. Latent, sleeping, not active.

Drought. A very dry spell or season.

Ecology. The science which treats of the inter-relationships of animals and plants, and of their relations to their environments. The study of the habits and modes of life of organisms. The migrations of lirds, distribution of plants, nesting habits of bamble-bees, are subjects of ecology. Often spelled areology. $16 \alpha$. 
Element. A substance which is composed of nothing else; an original form of mattex. $127 \pi$.

Emulsion. A more or less permanent and diffusible combination of oils or fats and water. $396,396 a$.

knergy. Power; force. Every moving, changing or vibrating body or agent expends energy or foree; and this force is transferred to some other body or form, for wothing is lost. The energy of sunlight is expressed in heat, light, and other ways. The energy that is required to produce the food is expended as bodily beat, muscular or nervous energy, and in other ways.

Éntomology. Science of insects.

Enviromment. 'The surroundings of an animal or plant, - the conditions in which it lives. Comprises climate, soil, moisture, altitude, etc. $16 b$.

Erosion. Wearing away; denudation.

Evolution. The doctrine that the present kinds of plants and animals are derived, or evolved, from other previous kinds.

E.reretion. A secretion which is of no further use to the animal or plant, and which is thrown off ; as sweat. $363 a$.

Extraneous. External ; from the outside; foreign to. 54, 59.

kxtrinsic. Secondary, external, from the outside. The apple bas extrinsic value, - that is, it is valuable as a marketable or moneygetting article, aside from its value as nourishment. See intrinsic.

E'ye. A bud; a cutting of a single bud. 235.

F'arm-practice. The management of the farm; the practical side of farming. It comprises the handling of land, tools, plants, animals. 11 .

Farmstead. A farm home or establishment.

Feeding standard. The jdeal amount and quality of food for a given purpose. ' 464.

Fermentation. The process by means of which starch, sugar, casein, and other organic substances are changed or broken down, and new combinations made. It is usually attended with heat and the giving off of gas.

F'ertility. Ability of the land to produce plants. 105.

Fiber. Elongated or string-like tissues.

Fibrin. An insoluble but digestible albuminoid. It is present in blood-clots.

Flocculate. 'lo make granular or erumbly. $58 a$.

Fodier. Food for animals. 428.

Forage. Plants which are fed to animals in their natural condition. or when merely dried. 330 . 
Free water. Standing rater, or that movins under the influence of graritation, as distinguished from that held by capillary attraction. $64,65,78$.

Function. 'The particular or appointed action of any organ or part. 'The function of the eye is vision: that of the heart is distributing the blood; that of the root is taking in food. What an organdoes. Fungicide. A substance which kills fungi. 295 .

Furrou. 'The trench left by the plow. 91a.

$[91,91 \mathrm{r}$.

Furou-slice. The strip of earth which is turned over by the plow. Gitng-plow. In implement remprising two of more individuat plows.

Figs. 64,65 .

Geology. The science of the formation of the erust of the earth. 20. Germ. See micro-organism.

Glacier. A slowly moving field or mass of ice; a frozen stream. Glands. Secreting organs. $363 b$.

Gluten. The soluble nitrogenous part of flour. 370.

Glyeogen. A starch, or stareh-like material, forment in the animal body, and from which sugar is formed. 364, $364+7$.

Grafting. The practice of inserting a cion or bud in a plant. 236.

Grazing. Pasturing.

Green-crops. Crops designed to be plowed under for the purpose of improving the soil. $74,109$.

Hard-pan. Hard, retentive subsoil. 94a.

Harrou. In implement which pulverizes the surface of the enround without inverting it or lifting it.

Heading-in. Cutting back the tips or ends of branches. 288.

Heary soils. Soils which are hard, dense, lumpy, or those which are very fertile. Does not refer to weight.

Herbivorous. Feeding on plants. 174.

Horticulture. Arts and soitenes prertaining fo chltivation of fruits, thowers, regetables, and ornamental plants. It is part of agriculture. $9,9 \mathrm{c}$.

Host. An animal or plant on which a parasite lives. y92b. A plant or animal which makes it possible for another plant or animal to grow alongside of it. $312 \alpha$.

Hotbed. A glass-covered box or frame which is artiticially heated (usually by means of fermenting manure), and in which plants are grown.

Humus. Vegetable mold. It may contain the remains of animals. Husbandry. Farming. lu. $[33,33 a$.

Hygroseopic. Holding moisture as a film on the surface, $64,6 \%$.

Inhibit. 'T'o prevent or check. 188. 
Inorganic. Matter which has not been elaborated into other compounds by plants or animals. All minerals are inorganic; also, air and water, $25 b$.

Insalivation. Mixing with saliva.

fusecticile. A substance which kills insects. 295.

Intermode. In plants, the space between the joints. 205.

Inter-lilluge. 'T'illage between plants. 85, 85a.

Intrinsic. Peculiar to, internal, from the inside. The apple has intrinsic value, - that is, it is valuable of itself, to eat, wholly aside from the money it brings. See extrinsic.

Irrigation. 'I'he practice of artificially supplying plants with water, especially on a large scale. $6: 3,6: 3 n$.

Imitable. In plants, responding to external agents, as to wind, sumshine, heat. 18:3, 208.

Larve (plural lare( ). The worm-like stage of insects.

Layer. A part of a plant which is made to take root while still attached to the parent, but which is intended to be severed and to make an iudependent plant. 22:9.

Leaching. Pussing through, and going off in drainage waters.

Leguminous. Belongring to the Leguminosa or pea family. 110.

Lichen. A low form of plant-life, allied to algre and fungi. The plant body is usually grayish or dull-colored and dryish. On tree trunks it is usually called "moss." $29 a$. Fig. 3.

Light soils. Soils which are very loose and open, or which are poor in plant-food. Does not refer to weight.

Mrarking out. Making lines or marks on the land to facilitate sowing or planting. 103.

Medium. A fundamental or underlying substance: soil is a medium for holding water. An agent: a root is a medium for transporting water. 49.

Aficrobe. See micro-organism.

Ificro-organism. A microscopic organism. It may be either plant or animal; but the term is commonly restricted to bacteria or mi crobes or grerms, which are now classed with plants. 35 .

Mineral matter. Earthy matter, -iron, potash, lime, phosphorus, ete.

Moldboard. 'The curved part of the plow which inverts the furrow slice. 91.

Mulch. A cover on the soil. 83.

Nitrate. A compound in which $\mathrm{NO}_{3}$ is combined with a base.

Nitrification. The ehanging of nitrogen into a nitrate. 137.

vitrite. A compound in which $\mathrm{NO}_{2}$ is combined with a base. 
Vitrogen. A gas, N, comprising approximately four-fifths of the atmospluere.

Vutrient, Food; aliment.

Nutrition. The process of promoting and sustaining growth and work of animal and plant.

Natritive ratio. The proportion hetween the proteids and other constituents in a foorl. 45 \%.

Optimam temperature. 'The best temperature for the performance of a certain function. 201, 3:31.

Organic. Pertaining to organisms, - that is, to animals and plants. Organic matter has been claborated or compounded of inorganic materials, and exists in uature only as it is male by animals or plants. Nlesh, wood, stareh, protoplasm, sugar, are examples. T'he chemist defines organic matter as that which contains earbou in combination with other elements. $25,256,32$.

Ornithology. Seience of birds.

Osmosis. 'The movement of liguils through membrunes. 184, 185.

Oxygen. A gas, $O$, comprising about one-fifth of the atmosphere.

Palatable. Of good or pleasant taste. 376,470 .

Particles of soil. 'The ultimate or finest divisions of soil:

Pedigree. A recorled genealogy. 486.

Prptone. A diflushle arul soluhlo compound formed from nitrogenous substances by the action of digestive liquids. 389,390 .

Perennial. A plant which lives three or more years. Rhubarb, apple trees and Candia thistles are examples.

[143.

Phosphate. A substance contuining or composed of phosphoric acid. Photosynthe:is. Making of organic matter from $\mathrm{CO}_{2}$ and water in presence of light. 198, 199.

Physical. Pertaining to the body or structure of a thing, as distinguished from its life or its spirit. Pertaining to the action of inorganic forces, ats heat, light, electricity, movement of water.

Physiology. The science of life-proess or of functioning. It treats of organs, and their work and uses.

Potential. Possible; litent. Said of powers which may be brouertit into action, but which are now dormant. $42 a$.

precipitate. 'Iho sediment resulting from chemical action. 390a.

Prepotent. Said of animuls which have the power of perpetuating their own characteristies to a striking degree. $48: 3$.

Protoplasm. A vory complex and changeable or manic nitrogenous com pound, present in all living things, and necessary to their existence. It is the living matter of cells. 


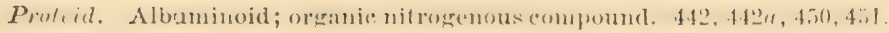

Pruning. Remering part of a plant for the betterment of the remainder. 278.

Plomaine. A product of decomposition of dead tissue. $409 a$.

Ptyalin. The ferment in saliva. 380.

Puddling. The cementing together of the particles of soils, rentering them hard and stone-like. 81.

Range. A pasture, particularly one of large extent. 488.

liation. The material fod to an animal.

liennet. The digestive principle derived from the fourth o: true stomach of ruminants: or the dried stomach itself. $392 \%$.

lietentive. Holding, retaining.

Reverted. Said of phosphates which are in the process of becoming insoluble. 145.

Root-cap. The tissue covering the very tip of the growing root. 206.

lioot pasturage. 'The area of soil particles exposed to or amenable to root action. $533,90$.

Rotation. A systematic alternation of crops. 112, 305, 305a.

Roughage. Forage, 330; particularly course forage.

Sanitation. Looking after the hea'th, especially making the condi. tions such that disease or injury is prevented.

Sap. The juice or liquid contents of plants. $207 a$.

Saturated. Full of water, so that it eannot hold more.

Scarify. 'T'o serateh or to harrow lightly.

Secretion. A special product derived from the blood : as saliva, gastric juice. $363 a$.

s'eed-bed. 'The earth in which seeds are sown. $243 \alpha$.

Seedling. A plant grown from seed, and not changed to another kind by prafting or budding. 2416.

Silicious. Sandy.

Slip. A cutting.

Soil. 'That part of the surface of the earth in which plants grow. 24.

Soiling. Feeding green fresh formge, in stable or field.

Sport. A variety or form which appears suddenly, or is very unlike the type. 485.

Stock. The plant into which a cion is set. 236. The parentage of any group or line of animals or plants. The animal tenants of a farm; live-stock.

Stoma, stomate. A breathing-pore. 188, 188a.

subsoil. That part of the soil which lies below the few inches of ameliorated and productive surfuce soil. It is usually harder, lighter colored, and porer in plant-food than the surface soil. 
Subsoiling. Breaking up the subsoil. 97.

Siubsurfece. 'The lower part of the surface soil,-just above the subsoil. $250 a$.

Superanuted. l'ast its usefulness.

Sinperphosphate. Sometimes used to designate available phosphates, and sometimes to designate materials which contain phosphate but no potash or nitrogen. $143 \alpha$.

Supersutureted. More than saturated, so that the water drains away.

S'upplementury. Secondary ; used in addition to something else.

Sulve. Hogrs, pigs.

I'ap-root. A root which runs stratight downwats, with no very large branches. Figs. 33, 79.

Terture. Of soils, the size of the ultimate particles.

Tillage. Stirring the soil. $84,84 a$.

Toxin. A poisonous production of decompustion. $409 a$.

Training. Placing or gruirling the branches of a plant. 278.

Transpiration. Passing off of water from plants. 187.

Trimming. Removing part of a plant 10 improve the looks or manageableness of the remainder. 278.

Yurbid. Musdy, cloudy.

Under-drainage. Drainage from below. The water is carried through the soil, not carried off on the surface. $57,68$.

Vrea. A waste nitrogenous eompound which is cast out through the kidneys.

Vurintion. Modifuation or change in an animal or plant. The coming in of new forms or types. Departure from the normal type.

riable. Having life; capable of living or growing. 216.

ritul. Pertaining to life or living things: vital heat is the heat of an animal or plant, as distinguished from the heat of the sun or of a fire.

Heed. A plant which is not wanted.

IVutersprout. A strong and usually soft shoot arising from an adventitious or dormant bud,-outside the regular place and order of shoots. "286.

Water-table. That part of the soil marked by the upper limit of the free or standing water. 57, 5ïr.

Zoölogy. Linowledge and seience of animals. 17. 


\section{SUGGESTIONS TO READING-CLUBS AND TO TEACHERS}

This hook hats foumd a plare in rearling-cureles. T'le following sugerestions on this use of the text

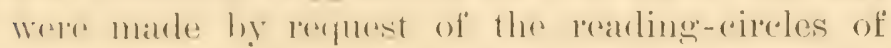
one stater, and they are preproblued here for the lumedit of others who mily similarly employ tho book.

In the production of its wealth, agrieulture oprerates in three great ficlds, - with the soil, the flant, and the animal. Although aided at every point by a knowlerge of other subjects, its final smeress rests on these hases, and these are the firlds to which the Principles of Agriculture gives most attention.

Aericulture is often said to be the most fundimmental and most useful of orempations, sinee it fereds the world. The provinee of a text-book of acrienlture is to deal with the original production of acricultural watth rather than with its manufaroture, transportation or sale.

The subjeret of atericulture is being considered rery anderally by sohools. This book is intented 10 smply the demand for a broad knowledge of thre sulfject, both ereneral and specific. It 


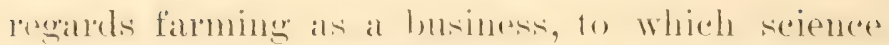
may be mate to rontribute a latrese measmes of stlorosss. It trealts thes subjeret from thes sirles of morluction, sinces it is mot maroticalnle to confuse this mief treatment with a dismasion of social rulal questions.

The encereal plan of the book is to state fumditnental principles in trese language withont very num explanation. In order to cover so murh erenurl, it is necessary to make the text very brist. It is romsidered that the bouk shomld not rum beyond three humberl lateres, elses it wonld be so large as to intretere with its gen"lat usefulness. The bare statement of principles is likely to be dry and monteresting, howevere and therefores some incidental and explana-

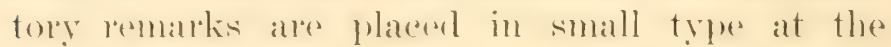

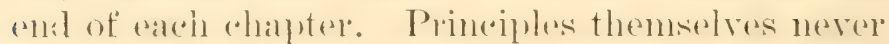
nexel piotures for illustration; hut the alpplicatfions of these principles are often marle plain hy the use of eneravinges. Therefore the eneravings alle placese in the explanatory text rathes than in the preliminary statements.

The whole lumk is itsolt a skeleton or outline of the subjert. It is expertorl that the rearler will fill it in as he gors alome, hy disconssion and

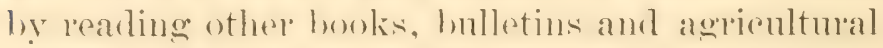
falpers. Somes useful roferences will be foumd in the explanatory matter. 
Spend at least one mesting on the 'l'alsle of Contents for the purpose of developing a creneral point of view on the whole sul,ject of agriculture. This book is made for adults of for those who are old enough to glasp a general riew of the subjects includer in agriculture. It is well to have all these subjects in mind at the ontset, so that the relative importance of each may be known and understood.

It will be noticed that the introduction is concerned with a general statement of what agriculture is. It has three co-ordinate divisions, as may be seen by the analysis on page ix. The first division attempts to define arriculture, the second to discuis the personal attributes on which successful agriculture depends, and the thimd defines the field of its endearor. Under. section 1 are to be found a definition of agri-

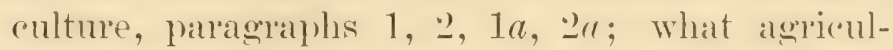
ture rontributes to the world, :3, 3 a; what acri"rulture is, $4, t a, 4 b$; definitions of acrienlture, b-9, sa, 9a. In section 2 , it is explained how sureessful farming depents on the exorutive ability of the farmer, in paragraphs 10-12; how

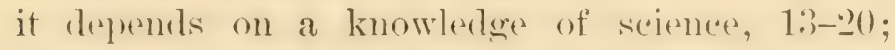
how complieated the business of arriculture is, 21 , 21a, 21b. In section 3 , there is an ontline of the things with which agriculture deals, in paragraphs 22, $22 a, 22 b$. 
Following are some questions that might he askere on this introduction in order to bring out the various points involved. These outlines and purstions may suggest how all the chapters in the book may be haudled with some degree of satisfaction:

1. What is agrieulture? Is it the same as farming? As husbandry? What are crops? What is stoek? What are direct and indirect products of the land?

2. Is marketing a part of agriculture? Define primary and secondary products. ('ontrast agriculture and manufacture.

3. What does agriculture contribute to the world? Is agriculture the most important of all arts?

4. What is an ideal husbandry? What is mixed husbandry and what speecialty husbandry? Which most completely maintains itself?

5. Define animal industry, horticulture, forestry. What relation do these bear to agrieulture? How is forestry popularly misunderstood?

6. Is the farmer a business man? Why is executive ability important? What is meant by personality and how important is it to the farmer? ('an executive ability be gained wholly from books?

7. What do you understand by the term farm-practice? What is the value of one's own experience?

8. What are staple and special products? How are prices made for these two classes of moducts? Which elass is the more important in the agriculture of your region?

9. Name two reasons why a knowledge of natural science is helpful to the farmer.

10. Disenss the relation of physies to agriculture. Of mechanics. Of botany. Of zöology. Of chemistry. Of climatology. Of geology. Explain what you mean by each of these terms.

11. Give some illustration of how complicated the business of agriculture is. 
12. Explain the three great subjects with which agrieulture deals.

13. Is agriculture a science or an art?

It will be noticer that the body of the book is rivided into three co-ordinate parts: the soil, the plant, the animal. These represent the three great fundamentals on which the sucoesstul practice of anrieulture depends. A complete treatise on agrienlture would include a division that wonld have to do with the general exonomic principles that underlie the business, and another on the social relations; but the insertion of this discussion would carry the present rolume quite herond its limits of usefulness as an elementary text-book.

\section{PART I. THE SOIL}

The soil is considered in several aspects. It is important to state at the outset that the mimary consideration is not the plant-food alone in the soil, but the physical characteristies as well. In the older books it was enstomary to place most of the stress on the chemical content of the soil. This was hecause agricultural chemistry was the first of the natural seiences to make great contributions to the arlvancement of agricultural knowlerdee. It is now murlerstood that the phrsical enustitution of the soil is as important as its ehemical eonstitution; it 


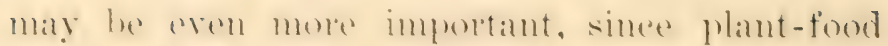
eate he aldedel if the soil has the propere phesical mako-up.

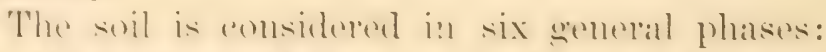
(1) the (2)

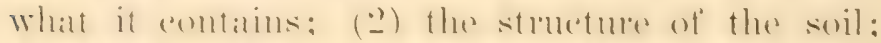
(i) the moistme in the soil: (t) the tillawe ()

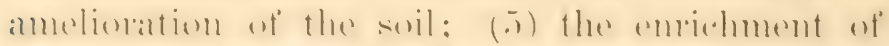

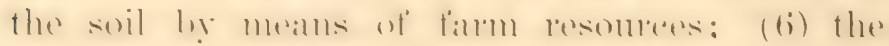

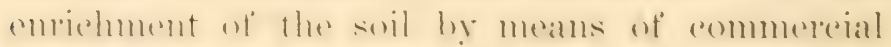
or concentrated materials.

\section{Chapter 1}

It the ontert, it is meressilly to gert a hroarl

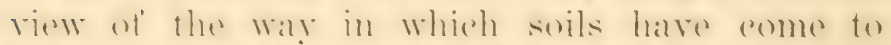
he. and what the enutent of the soil is. Is sol)m

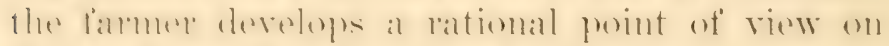
this subjert. the tiolds and hills amd swamps will have a new meaning to him.

What are the sonrees from which all life and wealth are derived? Which of these sources are beyond the control of man? What is solt? What is the meaning of the word soil as contrasted with land?

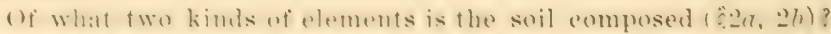
What is the phystal basis of the soil? What is meant by organie and inorganie (25al? What does the soil contain besides these two (lakses of materials (25)? l'he pupils should be asked to demonstrate the presence of inorganic matter in any soil (25e). What is meant hy weathering? How has the soil been formed by means of weathering (2(i)? What are the agencies by menns of 
which weathering frocends? Does wathering act on surfaces that are in general level as well as on those that are inclinet? P'upils should bring in a stone or briek or some other piere of mineral material that shows the effecet of weathering. Why aro pelbibes roumded? What has beeome of the partice fes that have disappeared from them? Why may weathering proceed less slowly on level areas than on steep hills? Why do mountains and hills tend to beenme roumded? Why are some mountain peaks sharp and others roundod? After weathering has proceeded, how are the detached particles distributed?

How do plants berome agrints in the formation of soil? Wheres do liehens grow? How do roots atet in the making of soil? Jlow do animals contribute to the making of soils? What is understond hy wemieal atetion (30)? Let, the teacher or pupil read some of the extracts from Datrwin's book on "Vegetable Mold," explatining how it is that the earth-worm eontributes to the formation of soil. Aro thero any soils in which organie matter predominates; if so, where are they formed, and how? What is humus? Ilow does it molify the texture and eolor of soils? What is the value of humus (3i3)? Jow may the farmer secure homus for his land? IIow important do you consider humus to be in the farming of your neighborhood? What is a miero-oganism? How do miero-organisms be nefit soils or contribute to the growth of plants? Do you understand that the soil is a scene of lifo as well a collection of materials?

How is soil transported and laid down? How may stones be a sourere of bernefit to land? What are the chice ageneies by means of which soils have been transported? What soils partake most closely of the nature of the bull roek on which they life? Explain how a stream becomes a transporter of soil. What is muddy water? Iset the pupil illustrate what there is in mudely water. What are glariel's? What has been their reffect on the soil on a large part of northeastern North Ameriea? Determine whether the soils of your regrion have been modified by the action of grlaricrs. What influenee has the wind in transporting soils? Illustrate from the sand storms of the plains and deserts. Is there dust in the atmosphere? If so, what is it and how may it he detected? 
Why is soil useful to plant life? How much plant-food may an acre of land contain? What is avalable plant-food? What is potential phant-twod? Is all of the plant-food in rommon soils avatible? How does nature restore or maintain the fertility of soils? How do man's operations differ from Nature's in this regard? Are all plant-food materials eyually useful to all plants? What eflecet hals deep-rooting on the soil, and on the amount of plant-food that the plant obtalus? Why are fertilizers useful? What is the reason for their appliention?

Let the circle or pupils read paragraph 48 in concert.

\section{Chapter :}

In this ehaptere we liseruss the terture and structure of the soil. WT shill find thit the anmlition of the soil is as important ats its ampesition. Fammers have always known this, but it is only resently that we hatre formed out the underlying reasons why. The suliject of "soil physies" has now eome to he of tirst importance.

What are the two general oflums of soil so fiar as the arowing of plants is concerned? May a soil that is rich in all the plantfools still be unadapted to the growing of erops? Why eannot erops grow on rock? Why not on very hard elay? What is meant by the "texture" of the soil? By the "structure"? What is the "physical condition" of the soil? In what language does the farmer express a wood physical comdition? What words does he use to express a poor physieal condition?

Name the reasons why good structure is important (52). Where do the roots feed? What relation has the size of soil particles to the amount of available plant-foody Illustrate this by breaking up a eube of sugar or a lump of chalk. Mathematically this could bo best illustrured by entting up a cube of wax. In what way, then, may the fining of soil be said to increase its pro- 
durfivity? What was Jethro Tull's theory of the value of the finimg of the soil by means of tillage (53c)? How important was 'l'ull's work, and why?

In what general way may the structure of the soil ho imploved? TThat is mrant by making the land "mellow"? What kind of lands aru mustly improved by being made mellow? What kind of lamis aro impored by being made compact or retentive? Name the three ways in which the size of the soil particles may be modified. What aro tho general uses of under-drainage? May under-draining mprove dry lands? What is the water table? Ilow is it morlifich by muler-draininer? What is an amendment? How does it improve or modify the alariater of the soil? What efferot mat lime bave when added to the soil aside from directly furnishing plant-foed? Name materials from which humus may be deriverl.

What are the values of stable manures? Does their value lie ilous. in the amount of plant-food that they contain? Illustrate the value of good soil textme hy the practice of the florist.

Let the class read aloud and in concert paragraph 60 ,

\section{Chapter 3}

It is important that the pupil get a firm grasp on the structure of this chapter, concerning the moisture in the soil. Notios that it is rlivider into four co-ordinate parts:

(1) Why moisture is important.

(2) How the water is held in the soil.

(3) How the moistme-holding callareity of the soil may be increased.

(4) The saving of the soil moisture.

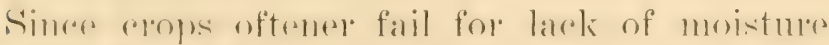
than for lares of plant-food, it is rery impurtant that this rhapter be given careful ronsirlegations. 
Why is soil moisture important in agricultural pratice? How do plants use water? How may the loss of water from the plant bo shown? What is irrigatiun? Dnder what conditions is irrigation admissible $(63 a)$ ? In what part of the eomnty is it a general practice, and in what part a special practice?

In what forms may water be hebl in the soil? Explain each of these three methods $(65,66,67)$. Make an experiment to show the eapillary powre of the soil. What is meant by the term "film moisture?" In what comlition is tho water held in very wet soils? When lands are in proper condition for the growing of erops, is the soil wet or is it mcist? Illustrate film moisture by dipping a mable or a stone in water. Illustrate cupillarity by applying one corner of a lump of sumar to water. Illustrate the transfer of water from particle to particlo by placing several lumps of sugar together and applying water to one of them. Where is the freo water of the soil? What is meant by a "leachy" soil? In what soils and under what conditions does water run ofl the surface? Does this wash of water from the surface do any ham aside from the loss of the water itself?

What is meant by the term "ranfall" How may the soil be made to hold the raintall? How may surface washing be prevented? How do soils vary in their eapacity to hold water. Make an experiment to illustrate the eapacity of the diflerent. soils to hold moisture $(72 x)$. How does the humus content of the soil atleet its moisture-holding eapacity? How important is humus in the agrieulture of your region? Is there sufticient rainfall in this resion to carry the crops through the season without resorting to irrigntion?

How is the humus in the soil depleted? State one reason why newly hroken or newly eleareil lands give the best crops. How may the humus be gradually increased? Is it possible to put too much humus in the land? The pupil should be instructed in the eftect of humus in ditherent kinds of soils. Soils that ne alrendy rieh in humus may he injued rather than benefited by the applieation of more, whereas those that nre lacking in humms or are very hara, or very lonse and sandy, may be greatly henefited. In many of the leess snils of the middle West the mblition of muel 
hmmus may be al decided disadvantage. Call attention to the fact that in very wiuly regrions the soil may be marle so loose and open and fine ats to bo exposerl to much damage hy wionds. In mew comutries bumus may be mores abumdant than in old lands:

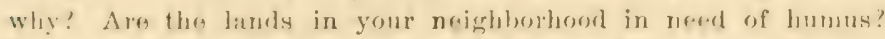
Illustrates when green-coropis shomld be polowerd under for that pur pous of giving the best results. What is the danger of plowing them under ton late in the season $(7+a)$ ?

Explain what drainage is. What is surface drainage and under-drainage? Ilow may surface drains be construeteol so as to infarfore least. With agricoldfural operations? What efferet has umber-rlminage on the soil? What afferet does a warm shower in spring have on land that is perferetly drained? What reffest dores a rool summer shower have? Explain somes of the practions of tile draininge as to depth of drain, distaneo apart of the difforent

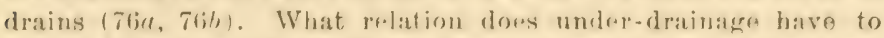
tap-rootrel plants (7Ror)! What is meant by the "soil reservolu?"

How does tillace emable the soil to hold moisture? How does

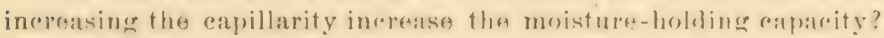
What is the general dieretion of the moverment of monsture by meaus of capillary attraction? May soil be made too fine? What is meant by "puddling" of soils?

What is mrant by the " (o) moisture escales from the land? What is mrant by thes "surface muleh" or tha "soil-muldh?" Ahout how mueh water is requireal in produre a pound of dry matter $(81 \mathrm{~h})$ ? How dores tillares save the moisture?

Explain (1) the general direction of movement of soil water in the growine suason: (2) how the moisture-holding reatureity of the soil may be increased; 1:3) how surface evaporation may be lessened.

\section{Chapter 4}

The tillage of the snil may now he ron-

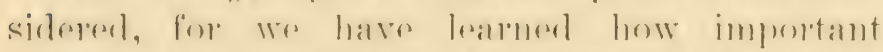

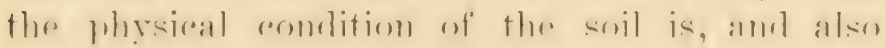


how necessary the moisture is and how it may be canght and saved. In rommon speech, the word cultivation is used for the stirring of the soil; but it is better to mse the word tillage, since this is a sperific technical word with no other meaning.

The present chapter has three co-ordinate parts: (1) what tillage is; (2) what tillage does; (3) how tillage is performed.

Explain what you mean by the word tillage. Why is tillage performed? Distinguish the two kinds of tillage (85). Crnder what conditions are these kinds practired? What is meant by deep and. shallow tillage? By surface tillage?

Note that tillage improves the land in three general ways. (Read the first clause in the paragraphs $87,88,89$. ) How does tillage improve the physical condition of the soil? What influrnce has it in saving moisture? What influence has it on the chemical actions taking place in the soil? Of what importance is air to the soil ( $89 \mathrm{a})$ ? In what sense is it true that "tillage is manure"?

Note that there are three general ways of performing tillage with respect to the kinds of tools that are used. What are they $(3: 3 a, 3 b, 3 c)$ ? Give seven reasons why we plow. Explain how plowing pulverizes the soil; the relation it has to green-manuring; how it increases the depth of the soil; what relation it has to hard-pan or subsoil: how it modifies the temperature and mnisture of the soil; what relation it has to weathering. Explain what subsoiling is and what it does. Define the words furrow and furrow-slice (91a). Describe what might be considered to be an ideal general-purpose plow.

Name the important surfice-working tools. Give five important influenees that surface-working has on the soil. What is meant by the "earth-mulch?" What is it for? How deep should it he? How is it made? How may it be destroyed? How is it reprairal? How often should it he repaired? If the earth-mulch 
itself is very dry, may it still be of use? At what time of the year is earth-mulch most useful? What relation has surface tillage to woeds? Why do we till?

Name tools that have a compacting influence on soils. Name some important uses of the compacting of the soil. What is the benefit of rolling the laml? What are the disalvantages? What relation has the rolling to germination of seeds? What relation to soil moisture? Does the rolling of the land require much judgment? Why?

\section{Chapters 5 and 6}

We now consiller the enriching of the soil. WTe have found that the soil is made to be more? productive by thorough preparation and by subsequent tillage. The plants are enabled to lay hold of the stores of plant-food, and many chemical activities are set up that result in rendering plant-food more available. The plant is given a comfortable and congenial place in which to grow. It thrives. Wre have fomm that the physical structure or conclition of the soil is of primary importance. Then we have secured the best physical condition and have done our best with tillage, we may then think of arding extraneous materials to the soil for the purpose of enriching it. That is, wat manme or fertilize the land. Whether this fretilizing pays ol not, depends wholly on comditions. The ardition of mere plant-foor is rarely profitalle muless the land is first in romdition for the very best growing of the plant. 
Anmures ale of two general rharacters; those that improve the textume of the soil, and those that all plant-forl. Barm mammes msmally perform both offiess, and this is one reatson why they give excellent results.

Is a mattere of farm-pratetiee, we may divide all fertilizers or mamurial substances in two great chasses: those that alle produced on the farm, and those that are boment from the markert. The best agriedulture is that whieh aims to proderee a good part of the neressary fertilizing materials on the fintm itselte. Thesese materials are by-produrets (sere definition in elossary).

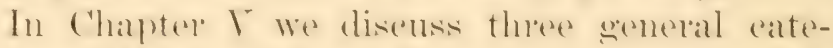
gorles: (1) what these fiam malnures are, (2) the emrohing of soil by means of epeps that alre plowed muler, (:i) direset alpplication of farm mamures to the land.

'The following questions will tend to bring out the various points in the chapter:

What is the real fertility of the land? llas it to do alone with plant foul? What is the first step toward increasing the produetiveness of any soil? What are the means by which this step may be taken? What is humus (review paragraph 33 )? How is humus secured?

What are green-manures? How much of the weight of a elover crop may be left in the ground (10sa)? Name the threo elasses of green-manure crops, and explain them. How may green-manuring erops be classitied, with reference to the ir nitrogen-gathering power? Nome some of the nitrogen-gatherers. 'To what family of plants do they belong? Name some of the 
r:itrenten-ansumers, or these that do not add nitrogen to the seil.

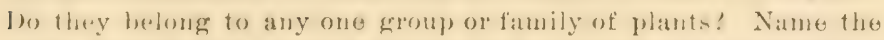

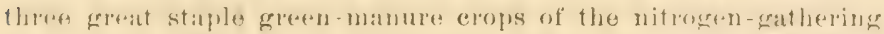
(1) iss (111). What is meant by intensive farming (1111)? What by extensive farming (111l)?

What is the ideal method of securing the green-manuring (rop in general agriculture (112)? Can a regular rotation ve fricelicend in most kinds of intenstre farming? Why is land benelitul by being "rested" in clover or some other crop? Explain how land may be benefited sometimes even by "resting" in wereds. What are the two values of green-manure erops (114)? Is it true that green-manures may bo valuable even when more platut-foor is not needed? Apply this to fruit-growing erops. How may a system of green-manure eropping be inaugurated on hard and poor lands? Where are cover-crops most useful, and why? How early should the cover-crop in owhands he plowed under? May weels ever bo useful in orchards late in the season? Why should they not he allowed to grow early in the season? What are the disadvantages of allowing weeds to grow even late in the season?

What does the application of stable manure do for the land? Ipon what does its value depend (119)? How should stable manures be protected or stored! Explain what you understand by a covered barnyard (120r). How ares stahle manures affected by exposure to the weather? What is the value of thoroughly rotted manure? What is the philosophy of composting manures? When the manures cannot bo sheltered or protected, what disposition may be made of them? What precautions?

What is the value of muck? What is peat, and what is its value? Discuss marl; also sawhust, straw, leaves, pomace, and the like. Lnder what combitions do you think it would pay to plow under straw?

In chapter VI the general discussion of fertilizer substaneres is comtinmerl, hut in this cases the subject is rommerebal plant-foorls. This is a subject of very great importance, palticularly 
in the older states, and it will be of increasing importance as the comntry grows older. It is at technical sulject, for the complete understanding of which much cheminal knowledge is needer. Pepons who desire to study the sulpget in detail shouhl consult special works and bulletins. Howerel, the general philosophy of the application of commeredial plant-fools may be mulerstood from this brief chapter.

It will be notioed that the chapter has six (oördinate parts: (1) what the elements of plantfood are in the soil, and which ones are most likely to be exhansterl; (2) the nitrogen supply; (3) phosphoric ar.iel supply; (4) potash; (5) amemdments, or those substancess that act beneficially on the structure or physical condition of the soil; (b) discussion of eommereial fertilizers.

What is a chemically fertile soil? What is an element (1:Ta)? How many elements are supposed to be necessary to the plants (1ㄴ. : mates 11,-117)? Which of these elements are wost likely to be depleted by the growing of erops? In order that these elements may he useful to the plants, what must be their relation to water? Do plants use these elements in their original or uncombined forms? What is meant by a compound in the chemical sense $(1: 31,1)$ ? What is meant by "available" plant-food? Ioes the soil contain much unarailable food of the elements that plants need? What makes plant-food available? What is the influence of tillage in this respect? Do roots themselves make plant-foods arailable (131 $\%$, review also paragraphs 30 and $30 a)$ ? What are the disadrantages in the use of barn manures?

What is the office of nitrogen? How does it affect the plant? How maly the lack of nitrogen be discovered? Explain what 
nitrogen is and what its sources are. What is ammonia? Nitrie acid? Nitrate? What is the relation of humus to nitrogen? What is nitrification? How is it hrought about? Is the nitrogen of the atmosphere used by plants? If so, through what parts of the plants is it taken up? How may we atd commercial nitrogen to the soil?

What is the chief office of phosphoric acid? What crops use liberally of it? What are sources of phosphoric acid? What is meant by the term phosphate! What is an acid phosphate? Superphosphate (143a)? Explain the relationships of phosphoric acid to lime. What is a "reverted" phosphate? In what forms are the phosphates found in commercial fertilizers?

What is the office of potash? What are the sources of supply? Whence came the commercial potash salts? Explain what muriate and sulfate of potash are.

What is an amendment? Give examples. How does an amendment affect the soil? What effect may lime have on land? In what form may it be applied? What do you understand by an aciu? Alkali? How many substances may be tested with regard to acility or alkalinity (153a)? Make the test with vinegar and with lye.

What is a commereial fertilizer? What is meant by a "complete" fertilizer? What is meant by "guaranteed analysis?" What is meant by the "brand?" What are the relative commercial values of nitrogen, phosphoric acid and potash? Figure out the commercial or estimated value of a ton of eommercial fertilizer when the guaranteed analysis is given. How may you determine what is the value of commercial fertilizer?

Would you alvise using a complete fertilizer, or only one of the fertilizing elements? Explain under what conditions. In what kind of crops is nitrogen ehiefly needed? Is there danger of losing nitroen from the soil? Do potash and phosphoric acid tend to leach out as rapidly as nitrogen? In what soils is leaching least pronounced? When are fertilizers applied, before or after fitting the land? Explain the six conditions that govern the application of commercial fertilizers 11 165). ('an definite rules be given for the application of surh fertilizers? Why? 


\section{PAR'T II.-THE PLAN'T AND CROPS}

Wo have now eompleted a cermeral review of the chandeteristies of the soil, the means of intproving its eomlition and of arlenge to its rish-

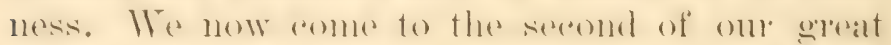
sulpjects-the enowing of plants. 'The enowing of many plants together lesults in the serming of

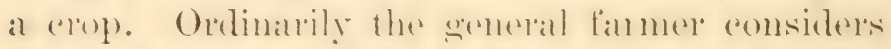
the erepe lather than the individual plant, whereats

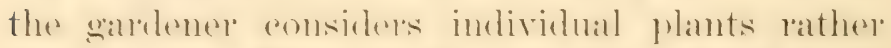

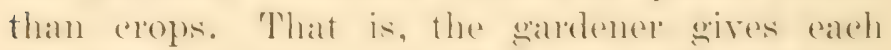
plant spereial calle. He often creows the plant in

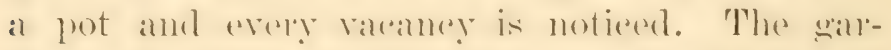
demere, therefore, is likely to seremes greater results from eareh plant than the eremeral firmere is.

It will be serent that this Part ll is latid out in six ehapters: (Vit) what the oftiers of the phant

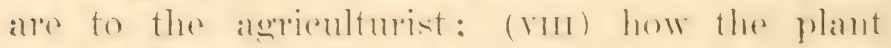

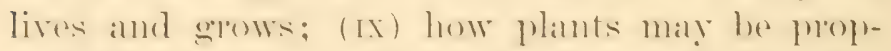
agated: (x) how lamel may he preparest in order.

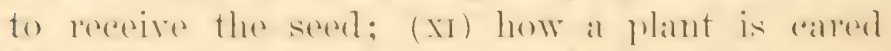
for after it has exerminaterl; (XII) a discossion of a few fumlamental cropse, as pasturager, niteatdow, and forage.

\section{Chapter $r$}

The followine ynestions will surdiate the rangere of the offices of the plant. Note that the 
chapter is divided into fivo comprlinate hearlis, disatssing the plant and the rople in its enemeral agricultural bearings; the plant in its relation to the soil; the plant in its relation to climale; the plant in relation fo animal life; and the plant in relation to man.

Name the general officess of the plant, as indicated in paragraph 167. What is meant by "erop"? Name a dozen crops. For what purpose may crops be grown?

How does the plant influence or modify the soil? How does it supply humus? How does it protect the soil? What value may a tap-root have (170)a)! How may plants be utilized to prevent drifting of sands and other loose lands?

Name four witys in which the plan influences the supply of moisture. How does it render the surface of the earth more inhabitable and enjoyable? What influence have forests on rainfall $(172 a)$ ?

What is the relation of plants to animals? Can it be said that "all flesh is grass?" What is the "rouml of life?" Let the class read aloud and in concert paragraph 175 .

Name some of the direct uses of plants to man. What are staple proluets? What are semi-staples? What are luxuries or acessories? What are condiments? What are beverages? What "lasses of piant produets eontribute to the food of animals? How are plants or their products used in the arts or manufactures? How are plants useful as objects of ornament? In what ways do they gratify our esthetic tastes and sentiments? What is floriculture? Landscape horticulture?

\section{Chapter 8}

This chapter, on how the plant lives, is intencles to give an ontline of some of the most important aretivities of plants. If the reader 


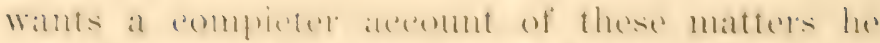

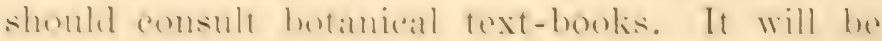

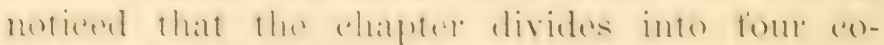
melinate heads: (1) what the platht antivities alle;

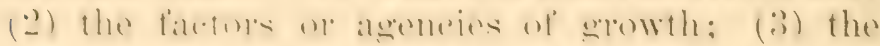

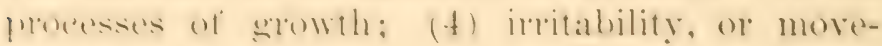
ment in plinuts.

What is meant by the phrase that the plant is a "deprendent structure?" With what must the plant bo supplied in order that it shall live and grow? What is meant by the sensitiveness or irritability of a plant?

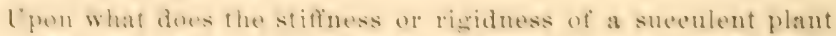
depend? Why dues sueh a shout wile when it is severed from the plant? What is meant by the turgidity of the cells? How does the soil-water pass from cell to eell? Explain or illustrate turgridity (litu). What are root-hairs, and what is their othice? How is it that these root-hairs absorb the soil water? What does the soil-water en tain? The pupil should atotnally see and examine root-hairs. Compare 1s.5b and figures 35-37. How much water do plants eontain? lo plants absold mere water than they need for purpeses of ford? It so, what beremes of the surplus? What are stomata? What is their altion? Illustrate transpiration fees tignres 40 and 10$)$. What is root pressure? Through what part of the plant does the suit water aseend? How may the path of ascent bo traced $(1,6)(1)$ ?

What is absorbed with tho soil-water? 'l'o what part of the plant does this soil-water, with its eontents. ge? lows the plant ahsorb only these substances that are use in building up its tissue? How may soil sulderanees that are not in solution be brought into that eondition? Name some of the leating substances that are brought in with the soil-water, particularly those that are of primary interest to the firmer? What is meant by the "ssh"?

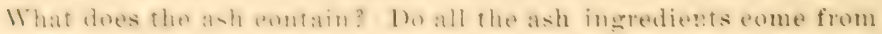
the soil? Do any of the non-ash ingredients come from the soil? 
Where dores the plant so "ure ity oxyen? What is meant by respiration in plants? How is it eompared with respiration in animals? When doess respiration chiofly take place? How way respiration be demonstrated (19tu)? How else is oxygen securenl than through the aërial parts? Do roots need air? Why?

What element is most aburnant in plants? Whence is it de. rived? How does it becerme plant-food? Irefines phostosynthesis. Compare it with reppiration. What is assimilation (198a)? What is chlorphyl (19sen? What is plant-food (198c)? In what sense may it be said that plants "purify the air?"

Jow does beat affect plants? What degree of heat is necessary for certain activitirs? In what parts of the world do green or sureoulent plant tissues most abound? Are all plants equally affected by similar temperature?

What substance results from photosynthesis? What becomes of it? Illustrate how starch may he detected (2033)? What are thes internal and external evidences of growth? Note that when a plant ceases to grow it begins to die. In what parts do young stems e.longate? How does the ront hehave in this respect? How may these differences be shown? How is increase in diameter effecterls Why does the external bark hecome furrowed and crack and break away? What is mwant by the word "sap" (20ia)?

How is irritability expressed? Name some visible movements of plants. IIow do plants move with reforence to light? With reference to sratitation? What is meant by the phrase "reaction of plants to their environment"?

\section{Chapter 9}

We now discuss the propagation of plants. Note that the chapter is dividorl inter threese coordinate parts: (1) a discussion of the gerereal means by which plants are propagated; (2) propagution by moans of serols; (3) propagation by means of burks. 
What ale the two erreat elasses of methods by means of which platuts are propatanted? What three ohjects hats the farmer in mind when he propagates plants? What do you understand by the term " propasation" as applied to plants? Why are not seeds always employed as a means of propatyation? What is meant by the term "to eome true to seed?" Fixplain why it is that plants that are hahitually proparated by buds usually do not come true from seeds ( $215 \pi)$.

What are furr ercueral requisites or proper conditions for the germination of seed? What is meant by the "vitality" of seeds? How do secels valy in vitality, and why? What is a "seed-hed?" In what ammlition shomhl it be? What eaution is sugerested for the hamdling of old and weak sereds? What is the reason for the soaking of sereds? How is oxysen applicd to germinate seeds? How may this smpply he incerased in a simple experimental way? What is meant hy the proper temperature for the sermination of serels? (ive examples of temperatures that are best for certain kinds.

What is the ideal soil for a seed-bed, and why? How is the depth of planting molitied by the kind of soil? Why is the earth packed ahout serels? What caution is given resperting the cover ing of very small sechs? What is meant by "res-serminating?" llow are very hat and hony seeds sometimes treated? What do you understand by the term "stratification?"

What do you understand by the phrase "propagation by means

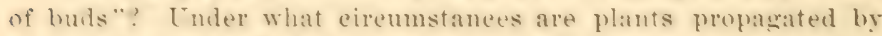
means of buds? What are the two general types of propagation by buds?

Explain what a lager is. Bring a shoot into the sehoolroom and show how layering is pertormed, or make a layer from some bush or tree nearby. What plants are proparated by means of layers? When are the layers separated from the parent plants? When may the operation be performed?

What are the two kimls of propasation by means of detached or separated buds? What is a eutting? A slip? A graft? 'Tell what softwood or greenwood enttings are, and explain how they are made and handled. What are hardrood and dormant cut- 
tincrs? How made and how handled? Name plants that are propagated by means of softwood cuttings and hardwood cuttings. What is a "single eye" cutting, and how planted?

What do you understand by the term grafting? ('ion? Stock? What is meant by the word "bud" as used by grafters or budders? Why do the cion and stock unite? Why is it necessaty to bind up the wounds or to cover them with wax? Explain the operation of cleft grafting. Of shield-budding. Under what circumstances and on what plants are these methods commonly userl? Of what age of wood is the cion usually made? When is grafting performed? Budding? Inw are plants made to be dwarf by means of grafting or budding $(2+16 b)$ ?

\section{Chapter 10}

The prepuration of the land for seed will now lw consislered. Having learned how plants ales Horuagated by the gardener, we may taki a moader view of the subject, and see how thro. ares started in the fields of the farmer. We shall now have to do with (1) the general factors that determine the preparation of the seed-berl; (2) the demands made by the plants on the soil; (:3) the actual making of the seed-bed; (4) the application of the foregoing principles to such funclamental srops as wheat, Indian corn and potatoes.

What is said about the loss from faulty preparation of land? Why is it so very important that the farmer should know what the

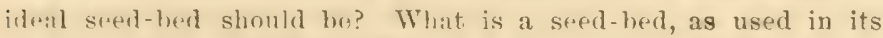
anrieultural sense (24:k)? What are the two factors that govern the preparation of the land for the seed-bed?

Io fine seexls de-mand a different kind of seerd-herl from wery 
latre seeds or from cuttiugs of potatmes? Why? How may plants chatnge their root system to alint themselves to different kinds of seced-heds? How is the seed provided with food to start it ofl before it ean seenes a foothold on the soil? Explain the diflerent chasaner of seed-hed demanded hy cherer and sugar beets. From what part of the soil do most of the farm plants derive their nourishment? How does a well prepared seed led conduce to the earliness of the cropl? How do plants differ in regatrd to the wharater of seed-bed that they require (Explain by contrasting winter wheat and Indian corn)?

Explain the importance of moisture to the germination of seeds. What kind of seed-hed is best for the preservation of soil moisture? lieview the remarks on the earth-muleh in Chapters III and IV, and make an applieation to the present disenssion. What is meant by the "suhsoil," "surface soil," and "sub-surface" soil? What is the value of rolling the seed-bed? Explain why the seed-bed should contain no free water. If it is desired to plant seeds unusually early, what must be the preparation of the seed-bed, - that is, how may the soil be warmed up? What effect has under-drainage on the germination of seeds (251 $(1)$ ? What can rou say ahout soils that tend to bake? What is the alrantage of sowing seeds very early? Do all seeds that germinate make gond plants? Are those that fail to make goond plants necessarily a total loss to the farmer? Inder what conditions are seeds sown on the surface of the soil without the actual preparation of a seed-bed? What cautions are given respeeting the making of seed-heds on clay lands? Why is summer-fallowing practiced as a preparation for wheat growing (255b)?

Discuss the sped-hed that is best for winter wheat. Inder what system of tillage mat this seed-bed best be seenled? What effect does this seed-bed have on the ront srstem of the wheat Whant? Why is it best that wheat roots should not go directly Anwmwards deep into the soil? Is it mobable that the ront system of the wheat plant tends to change somewhat as spring adrances?

What is the ideal seed-bed for maize or Indian corn? How dues it differ from that of wheat? What are the best machines for planting corn? When may the young corn be tilled? 
What is the proper seed-bed for potatoes? Should they be yinted deep or shallow? Should they be grown in level cultue or on ridges?

\section{Chapter 11}

Having now discussed the preparation of the seed-berl and the starting of the crop, we may give attention to some of the principles that muderlie the subsequent care of the plant. This care falls under three general categories: (1) the care given by means of tillage; (2) the care given by means of pruning and training; (3) the care given by keeping insects and fungi and other enemies in check.

What is the first consideration in the care of the plant? What are the objects of tillage? What can you say about weeds? Name some of the general means of keeping weeds in check. How often should surface tillage be given? Is it ever practicable to till sowed crops? How late may it be advisable to till corn by means of harrows?

Is tillage advisable in fruit plantations? Why is it that fruit plantations may do better without tillage than corn or potatoes do? Why is it very important to till fruit plantations early in life? May the orchard need clean tillage throughout its whole lifte? May sod ever be employed in an orchard to adrantage? should fruit plantations be tilled uniformly throughout the entire season? Explain a good general method for the tillage of fruit lands.

What is pruning? Training? Is pruning unnatural? Explain by reference to a tree top what is meant by the phrase "struggle for existence."

Explain how wounds heal. What are some of the factors that determine the proper healing of wounds? IIow does the serison of the year in which they are marle influence the healing? What 
should be the length and form of stub or stump when a large limn is ent away? What is the value of dressings on wounds? Ilen tion one or two good dressings.

Explain why we prune. What is the result of heary pruning of the top? Heary pruning of roots? What are watersprouts? What influence has the checking of growth? How may this checking of growth be brought about? What is the philosophy of heating-in yomur shouts? Evplatin the eflects of pruning every year versus heary pruning in ocensional years.

What are the leading kinds of enemies of plants? Explain thes two general types of insects with references to their methods of feeding. Give illustrations in each. What are some of the ablsses of fungens pests with referemee to their manner of livingr? What is meant by physiologieal or constitutional trombles? How are these troubles to he distinguished? What is a fungus (20) $a)$ ? What is a host $(2926)$ ?

What are the first requisites to keeping plants free of insects and fungi? What is meant by prophylaxis (2!)ta)? Name the thee seneral ways in which insedets are killed. What are the caustic applientions? Discuss the poisonous applieations. What plasses of materials are used as fungrediles! What is Bordeanx mixture? What is meant by the term "sprayinge" Explain how spraying shouhl be performed. How are you to determine what is the hest spuy pmmp? Is spraying alome sufticient to keep plants henlthy? Explain the different formulas.

\section{Chapter 12}

Wh now biss to a disemssion of pastures,

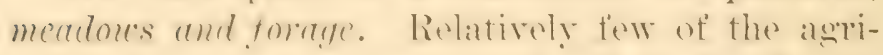

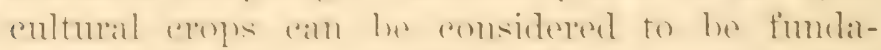
montal. that is. to molerlie the wermeral system

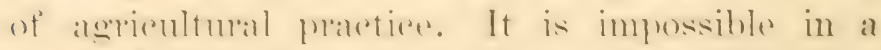
work of limited sonper to lisemss the rultivation af many ropse hut somm at the prineiples that 
monderlie colol cultivation (:an be well illustraterl with a few examples. Since grasses aml other forage rops arr of such miversal nse, these have been chosen for illustration. Note that the "hapter begrins with (1) a gesnelal discussion of the importance of grasses; (2) permanent pastures; (3) mearlows; (4) other forage plants.

Why is grass said to be the fundamental crop? What is meant by the term "grass" as used in its popular or general-language sense (304t-304e)? What do you understand by the term "rotation of crops?" What are the advantages of rotation? How important is grass in such a system? Give one or two examples of good rotation of erops $(305 b)$. Explain how the number of grass plants to a square foot may be modified by the uses to which the plants are to be put.

What is a "pasture?" What is a "permanent pasture" (307 $(l)$ ? How shnuld the land he prepared for the making of a permanent pasture? Explain how pastures may be made on different kinds of soil. Explain how a good pasture may he secured on land thit has been eropped too continually and failed to produce well under rotation. Why is it necessary to prepare the soil for permanent pasture very thoroughly? Why does the pasture tend to fail with age?

Name some of the kinds of grasses that may be employed in the making of a permanent pasture. Why are elovers said to be "host plants" to the grasses $(312,312(\iota)$ ? How may clovers be maintained in pastures? As pastures begin to fail for lack of plant-food, how may they be revived? Explain how important constant watchfulness is to the maintenance of a permanent pasture. What is the necessity of keeping the ground constantly and evenly covered with swarl? What ean you say about pasturing too elose? About letting the grisses run to sperl? What is said ahout the importanee of shade on the surface of the masture lands and how it may be secured? Recapitulate (as in parafraph 317) the essentials in the making and keepiner of pastures. 
What is a "meadow?" How does it differ from a pasture? What is an aremge yichl for a meahow? What is the importane of a mendow in the wotation? In what kinds of meadows are the aracest yedis usually seeured? What is the abantage of mixing vleve: with the grasses? What are the atvantages of mived and momived meatows for hay? What is the howest average yeld at which a mendow ean be considered to be protitable?

What is a "premanent meadow?" When may sueh meadows be advisable? What is the problem wish howland meadews? How should the namber of phants per square fout differ between meahows and pastures? Hhw may modows be tilled or prevented from beeming "hide bound?"

Name some of the grasses that are best mapted to merdews. How mueh seed may be sown of grasses and elorer? Xame some of the grasses of soevmary special importanee. Sugrest how much seed may be required to an acre.

What is menut by the term "ierage plants?" ly "roughage" (scee ghossary" What are "soiling" plants? What general remakks ean you make about the growing or tilling of forage plants? What sre the two leading forage plants of the Cuitci states? leseribe them and tell where their greatest areas of produetion are. Name some of the annul forage plants of secondary value.

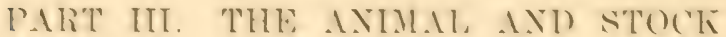

Sote that there are two sumeral subjerts emesileverd in this part of the hook. These subjects are: the anmal as an indiridual, and an angeregation of animals known als live-stopk. Befores one eam hamble animats in epoups or berome a stock farmer. he must kmow the eharateteristies of the imlividual animals and how to fered and treat them. 'This palt of the hook is divided into four aeneral parts: (1111) the eneneral oftiens 
of the arimal to agriculture; (xw) anirnal physiologry, or how the animal lives and grows and

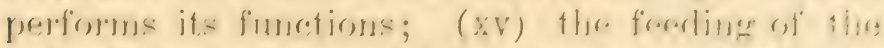
ammal at a mattore of farm prartion; (XVI) thes general managenent of the strok.

\section{Chapter 1:3}

We first discuss the offices of the animal. Nofes that the offices of the aninal as leslated to the farm are thrown into several general learls. Cite what these heards are.

Explain the offices of the animal as outlined in paragraph s:36. What is strek? Nams sorno of the animals that ares includerl under this trerm. How dores the animal haves relation to thes groil in resperet to maintaining and incereasing fortility? What rwatar,n has stoek to the disyersition of the cropes of thes farm? Explain hesw the animal itself has intrimsie value to marn. Classify the

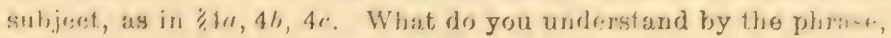
"Hore animal as a berast of burdern?" In what ways dores the animal perform labor for the farmer? Jow may thre animal aret as a destroyer of pests? What influenes has thes streck irslustry or th.. divorsificalion of labor? What is meant by thes phrase "diversification of latuor?"

\section{Cllapter 14}

Notr that there arr six roiridinate parts in this rlatpher on how the aninal liees. Crive theses six parts in their ordere or write them on the blacklonard.

This chaptor is somewhat technireal, and 


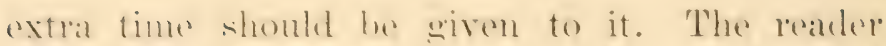
will he well to stuly it motil he feols at semse of mastery of the subject as here presented.

What is a cell? Why does this disenssion begin with the cell?

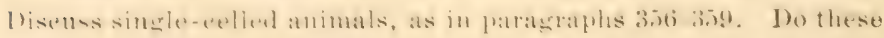
lowly animals have distinet organs? What is meant by "manycelled animals?" What are the ontices of individual cells in these many-celled animals, as compared with that of singlo-celled animals? What is meant by the "process of nutrition?" By the "nervous processes?" By the "processes of secretion" ( $363 a)$ ? What are glamds (363h), and what are some of their oftices? What are the ofteres of the eorpuseles of the bleod? With what may these eorpuseles be eompared? What is the lymph and the lymphatie system (atis, atich)? What is meant by a speceialized and a generalized organ or organism (360/2)?

What are the kinds of food as outlined in 367 ? What are herhivorons animals? C'amivorous? How to the digestive organs of the herivivorous animals differ from others? Compare the dienstive apparatus of the horse with that of the ox. How does artiticial eare and selection molify the siae of the digestive organs? What must all fords eontain in order to be of use to the animal? Name nitrogenous foods. Name non-nitrogeneus foods. What is the speredal othee of the lattr.r? Are the non-nitrogenous foods ever formed from the nitrogenous? How? What is meant by fat (:3i, la)? What are the mincral salts? What is the eonstitution of ideal food? What is meant by a well-balanced ration? C'an a detinite mathematieal ration be construeted that will be of eyual value for all animals? Explain.

What is digestion? What is the alimentary canal? What are the digestive secretions? Disenss saliva. What is the active principle of saliva, and what is its offlee? What are the ofliees of the rarious stomachs in ruminating animals? What is the othee of the ehewing of the end? How do the salivary glands differ between youth and age? What relation has this to the kind of fond that an animal should have? What are the three digestive prineiples produced by the stomath? Deseribe them. What is 
an antiseptic (3xia)? What is prepsin and peptonw? How ane peptomes distinguisherl? What is their offire? What is tha milkcurdling ferment? What is a ferment (379re? What is renmet, and for what is it used? Where is the gastric juire srereterl in birls?

What digestion takes place in the intertines? Jescribe thr, fluids there serereted. What is biles and where serreted? What is its olfire? 1)iscuss pancentic juice. What is monnt ly an emulsion $(396 a)$ ? What is the intestinal juice?

The varions foods having been digested, they are now to be aberbed or taken into the hodily system. Describe how they are absorbed by means of villi. Deseribe what a villus is. Into what fluids do these digestive matters pass?

'The blood having reneived the digested forols, these materials now go to varions parts of the borly to build up the tissues and repair waste. What is one of the most important new produrets resulting from digestion? What transformation takes place in the liver? What are ptomaines and toxins $(409 a)$ ?

What is breathing? What is the relative erostitution of inbaled and exhaled air? How is tho air brought into contaret with the blood? How is the blood cirrulated in the warm-bloculed animals? What is the nature of blood as it goes from the heart and returns to it? What beecomes of the exress of oxyern in the new or pure blood? Where does the real effect of breathing take plarer? How is the amount of needed air modified by the condition or aretivity of the animal? How does the amount vary between different spereies of animals? At what point does air hes. eome unable to support life becanse of carbon dioxid? What is the value of good ventilation? Give any practical hints.

What is meant by "waste of tissue?" Under what eonditions does waste proceed most rapidly? Under what conditions is wasto repaired? Does the waste take place in exact proportion to the energy or work expended by the individual? When will the animal lay up fat? Under what conditions are milk-produeing animals profitable to their owners? What are the most favorablo conditions for the fattening of animals? What are the dangers of too close confinement? Is the animal body to be likened to a mere machine (426)? 


\section{Chapter 15}

Note the four co-ordinate parts into which this chapter on the feeding of the animal is divided; namely, somres from which animal food is secmed, how the animal uses the food, the composition of fodlers, and the practice of feeding.

What is the nature of animal food? What is a fodder? What must fodder contain in order to be useful?

How is it that the animal is able to secure energy from the materials stored in plants? How does the animal first expend energy on the fool? How may the profit in forlder be represented? Why is it that some substances that contain an ahundance of plant-fool may still be unprofitable for feeding? Name the five ways in which the animal uses fodder. When the food is seant and insuflicient, how is it used? That is meant by "food of maintenance," "food of support," and "food of production?" Is all the food or material consumed by the animal of use to it in building up animal tissue? Why? How does the proportion of food digested vary in different animals? How does it rary with the character of the food itself?

Name the various clatses of substances which compose fodders. To what extent is water present in fodders? What is a byproduct (4:Tin? What is the use of the water to animals? How does the water content increase the value of fodder in general? What is ash? From what sources do animals secure all the ash that they need? What is the importance of albuminoids as fodder constituents? What elements do they contain? How does the "omposition of albuminoids vary? What are carbohydrates? What is the signifieation of the term from the chemical point of view $(445,1)$ ? What is the particular office of carbohydrates? What is meant by fiber? Discuss the importance of fats in fodders. How is the feeding value of fat expressed (449)?

What are the classes of follier that are of distinct use to the 
animal? What are they called collectively? What is a ration? That is a balanced ration? What is a nutritive ration? What is a "wille" and a "narrow" nutritive ration? Give an example (as sugrested by $453 a)$. What is the value of the nutritive ration in actual feeding practice? Which of the food constituents is most likely to bo lacking and is most needful, therefore, to be supplied? ()n what does the quantity of food required by an animal depend (4ik, 4ikn, 459)? How does the amount vary between youth and ade? How is the profit secmed from feeding? Lpon what does the amount of "food for production" depend? Give an illustration (462). Is the food that an animal actually eats a measure of the amount that it actually noeds? Fxplain. What is a feeding standard? Give an example. How may these feeding standards be varied? What is the advantage of mere bulk in ration? What are the substances that give bulk to a ration? That is meant by the term "coarse" as applied to fodders? What by the term "concentrated folders?" What is the danger in providing a too bulky ration? About what proportion of dried matter should a particular ration contain for eud-chewing animals? For horses? What is meant by palatableness? What is its value in fodders? Give one reason why silage is a grood fodder. What is silage $(469 b)$ ? If there is any adrantage in cooking foods, explain what it is. What is the advantage of eutting or shredding fodders? What is the advantage of variety or chauge in the food given to an animal?

\section{Chapter 16}

A brief discussion of the management of stock may now be undertaken. Note the four divisions into which this chapter falls: as, the breeding of stock, where stock raising is adrisable, how much stock can be kept on a given area, and the care of stock in general.

What is meant by the propazation or increase of the race? What is necessary beyond the mere propagation of stnek? What 
is breeding and what are its two objects? What is a breed? Name breeds in various classes of stock. When may a man be said to be a stock-breeder? What is meint by the "mental" ideal, and what is its value in stock-breeding? When may the ideal be impracticable? How does the ideal vary with different classes of stock? How are animals judged in regard to their excellence? What is meant by the judging or the seoring of animals (481a)? If po-sible, apply the score cards on pages 276 and 277 to animals for which they are intended. What is the first practice in breeding for an ideal? What is the second point? What is meant by a "prepotent" animal? Give some of the common characteristics of a prepotent animal. What is a "sport"? What importance do these sports usually have in the improvement of the race? What is meant by the term "fixed" as applied to breeding? What is a pedigree? What are the advantages of a pedigree $(486,486 a)$ ? What is meant by pure-blooded stock? Is pure stock always to be advised for the general farmer, and why? How may the farmer secure the advintages of good breeding $(487,487 a)$ ?

In what regions and under what conditions is live-stock growing particularly advantageous? Discuss the advantages of the West and Sonth where the range areas are large. Discuss the narrow and sheltered valleys of the North. What is the general tendency respecting the extent of stock raising? Name some conditions under which a large quantity of stock can not be kept with the most profit. Let the class read paragraph 491 in concert.

How much stock may be profitably kept on an acre in the rich prairie countries? How much on farms in the East? What are the two theories or principles controlling the quantity of stock a farm can keep with profit? Explain the practice of buying stock to feed. What are the economies of this practice when figured on the basis of whent bran $(496,497)$ ? When is this practice of stoek-feeding likely to be profitable? What is one reason for the growth of this practice ( 499 ? What is the value of stock feeding in respect to maintaining the fertility of the land $(500,500 a)$ ?

What is the general importance of making animals comfortable? Discuss ventilation, and how secured. Discuss the tem- 
perature at which stables should be maintained. Discuss the importance of light, and how it may be controlled. Discuss also the means of storing the manure. Discuss some principles that underlie the watering of animals. How does the ration vary with the animal, its age, and the conditions under which it is kept? How should the ration and time of feeding be governed? What is the danger of feeding too much at any one time? Let the class read in concert paragraph $510 a$, at the bottom of page 279 . 



\section{INDEX}

Accessories, 109.

Acid phosphate, 94, 95.

Acir soils, 97, 98, 104, 189.

Acidity, 234.

Asthetic tastes, 109.

Agassiz, referred to, 35 .

Agricultural chemistry, 9, 113.

Agricultural colleges, 2.

Agricultural physics, 6.

Agriculture, 1, 11, 14.

Air in soils, 38, 72 .

Albumin, 213, 219, 255.

Albuminoirls, 245, 246, 248, 257.

Alfalfa, 192, 199.

Alimentary canal, 215, 233.

Alkaline, '2:34.

Alluvial lands, 24.

Alps, denundation of, 30 .

Amendments, 40, 97.

Ammonia, 90, 91.

Amoba, 231.

Amylopsin, 221.

Anacharis Canadensis, 128.

Analysis of soil, 42 .

Angleworms, 17.

[271.

Animal, feeding of, 240, 247, 266,

Animal, how it lives, 208.

Animal industry, 2, 3 .

Animal locomotion, 7 .

Animal, the, 201.

Animals and soil-building, 16 .

Animals, species and breeds, 14 .

Animai-kuowierge, 8.
Antiseptic, 164, 173, 218, 234

A piculture, 3.

Apple, propagation, 144.

Apple, varieties of, 14.

Apples, 108.

Apples, tilling, 161, 162.

Apple-scab, 167, 175.

A pple-worm, 205.

Aquatic plants, 19.

Arthur \& MacDougal, 128, 129, 131

Arts, animals in, 203.

Ash in foods, 212, 243.

Ashes, 96.

Assimilation in plants, 118, 128.

Astronomy, 15.

Atkinson, referred to, 124, 128, 131.

Availability, 88, 104 .

Babcock test, 278.

Bacillus ubiquitus, 35.

Bacteria, 35, 167.

Bailey, quoted, 31, 33, 45, 76, 84 , $111,129,130,131,140,157,171$.

Banana, 1.

Barley, 106.

Barley and pastures, 181.

Barley, wild, 191.

Barn, 268, 269.

Barnes, referred to, 131.

Barn-yard, 82, 85, 86.

Bayous, 23.

Bean, germination, 124.

Bean soil, 42. 
Beans, 5, 92, 108.

Beans and moisture, 57.

Bedding, 267.

Bee-culture, 3, 11.

Beef, 11, 203.

Beet, sugar, 147 .

Beetles, 166.

Bermuda grass, 181.

Bererage, 108, 109.

Bicjcle, 204.

Bile, 220, 236.

Birds, digestion in, 220.

Birds, tame, 204.

Black-knot, 167.

Blights, 167, 17t.

Blood, 210, 211, 222, 226.

Blood, dried, 92, 203, 206.

Blue grass, 181, 190, 195, 197.

Bogs, 20, 181.

Bone, 93, 207.

Bordeaux mixture, 169, 173, 177.

Borers, 167, 168.

Botany, 7, 15 .

Boulders, 24.

Bran for feeding, 266.

Breathing in animals, 224.

Breeding, 8, 259.

Breeds, 15.

Brisket, 272, 276.

Buckwheat, 79, 108, 136, 181.

Bud propagation, 136.

Budding, 139, 140, 144.

Buds, opening, 130.

Bulk in ration, 252.

Burning of solls, 29.

Business, 4, 9.

Butter, 1, 11, 202.

Buttermilk, 255.

By-products, 255. 266.

Cabbage, club-root, 175.
Calcium, 87, 116.

California Experiment Station, 63.

Callus, 138.

Cambium, 121, 139.

Canned fruits, 11.

Cavacity of soil, 50, 59, $15 \overline{\text {. }}$.

Capillary water, $48,55,58,150,157$.

Carbohydrate, 127, 243, 246, 256.

Carbon dioxid, 104, 117, 118, 127.

$129,224,235$.

Carbonate of copper, $169,17 i$.

Care of stock, 258.

Carex, 194.

Carnation, 14, 106.

Carnirorous animals, 108, 212

Casein, 213, 218, 219, 256.

Catch-crops, $78,80$.

Cats, 108, 204.

Cattle, 3, 14, 108, 201, 212, 272.

Cauliflowers, 109.

Caranaugh, chapter by, 87 .

Cereals, 181, 263.

Charcoal, 104.

Chautauqua belt, 14 .

Checking growth, 165.

Cheese, 1, 11, 219, 235.

Chemical action, 32 .

Chemicals in schools, 105.

Chemistry, 8, 13, 15.

Chester, quoted, 34.

Chicken, 3, 235.

Chine, 272.

Chlorophyll, 118.

Chrysanthemum, 14.

Chyle, 235.

Cider, 1, 109.

Cion, 139, 144.

Civil engineering, 7 .

Cla5, moisture in, 51

Climatology, 9 .

Climate, 3, 9, 107, 111. 
Clinton L. A., chapter by, 47.

Clinton, L. A., referred to, 76.

Clod-crushers, 69.

Clothing, 1.

$[80,81,84$.

Clover, green-crop, 22, 67, 78, 79,

Clorer in meadows, 181, 186, 189 ,

Ciover roots, 110.

[193, 199.

Clover, plant-food in, 203, 206.

Clover, seed-bed for, 151.

Clovers and nitrogen, 92

Club-root, 175.

Cobbett's 'Tull, 72.

Colleges, 2.

Come true, 136, 140.

Comfrey, 191.

Commercial fertilizer, 95, 98, 203.

Compost, 34, 82 .

Compounds, 88, 103.

Condiments, 109.

Conservation of moisture, 56,65 ,

Constituents of food, 213, 242, 266.

Constitutional troubles, 166, 167,

Cooking food, 254. $[170,174$.

Copper fungicide, 169.

Corn. See maize.

Cornell Experiment Station, 63.

Cotton, 109, 120.

Cotton-seed meal, 267.

Cover-crops, 52, 79, 80, 162.

Covered yard, 82, 85, 86 .

Cow; air required by, 228, 269

Cow, points of, 273.

Cows, feeding, 267.

Cows, standard for, 252.

Cow-peas, 79.

Crabs, 206.

Crop of fowl, 220, 235.

Crops, 106, 202.

Cultivators, 69.

Culture, 72.

Currant bug, 174.
Currants, cuttings, 138.

Cut-flowers, 109.

Cuttings, 138, 142.

Cypress knees, 127.

Dairy husbandry, 3.

Daisies in meadows, 31, 170.

Darwin, quoted, 13, 33 .

Davy, work of, 13.

DeCandolle, quoted, 14.

Delta, 35.

Department of Agriculture, 13.

Dewlap, 273, 277.

Dicalcic phosphate, 95 .

Digestion, 215, 240.

Discovery, 12.

Diseases, 8, 10, 162.

Ditches, 53, 60 .

Diversification of Iabor, 205, 207 .

Dogs, 108, 204.

[265, 278.

Drag, 76.

Drainage, 53, 60 .

Drains, 48, 53, 60 .

Dressings, 83 .

Dressings for wounds, 164 .

Dried blood, 92, 203, 206.

Dried meat, 206.

Droughts, 49, 24.

Dueks, 3, 200.

Duggar, B. M., chapter by, 112.

Dust in air, 35.

Dwarfing, 137, 144.

Dyes, 109.

Earth-mulch, 57, 65, 69, 71, 149.

Earthworms, 17, 33.

Ecology, 8, 13.

Eel-grass, 19.

Egg, white of, 213, 256.

Eggs, 1, 11, 202.

Elements, 87, 103. 
Elodea Canadensis, 128.

Emulsions, 168, 175, 221, 235.

Enemies of plants, 166.

Energy, 24n

Engineering, 7.

Enriehing land, 77.

Ensilage. See silage.

Entomology, 15.

Environment, 8, 13.

Escutcheon, 273, 276.

Evaporated fruits, 1

Evaporation from plants, 113, 114,

Fxhausted lands, 27.

Experiment stations, 2, 13.

Exploration, 12.

Extensive farming, 86.

Factorr. 11.

Fallowing, 158.

Fall-plowing, 40.

Farming, 1, 11.

Farm-manures, 41.

Farm-practice, 4, 28.

Farm resources, 77 .

Fats in food, 213, 229, 243, 247, 256 .

Feed-mills, 7 .

Feeding of animal, $240,247,266$,

Feeding standards, 252.

$[271$.

Ferment, 233.

Fertility, real, 77

Fertilizer, 41, 43, 95, 98, 203.

Fertilizers, brands of, 15 .

Fescue, 190, 191.

Fiber in foods, 243, 246.

Fibers, 2, 28, 109.

Fibrin, 219.

Film moisture, 49, 59.

Fish, 3, 201, 203.

Fish, ground, 204, 206, 207.

Flax, 109.

Flesh is grass, 108.
Float, 71.

Floating islands, 20.

Floriculture, 3, 109.

Florists' plants, 46.

Flour, 11.

Flower-pot experiment, 57, 59.

Flowers, varieties, 15.

Fodder, 109, 239.

Food constituents, 213, 243, 267.

Food, cooking, 255.

Food of animals, 108, 212, 240, 213

Food, quantity of, 250, 258, 266.

Forage, 109, 191.

Forcing-house, 86.

Forest a crop, 106.

Forestry, 2, 3, 12, 111.

Fowls, 3, 259.

Fowls, digestion in, 220.

Foxes, 212.

Free water, $48,50$.

Freezing pulverizes soil, 68.

Frigid zones, plants in, 119.

Fruit-evaporating machinery, $\boldsymbol{7}$.

Fruit-growing, 3, 11, 80, 96.

Fruit plantations, tilling, 16 .

Fuchsias, cuttings, 138.

Fungi, 166, 167, 169, 173.

Fungicides, 169 .

Furrow, 72.

Furrow-slice, 74 .

Gang-plows, 163, 171.

Ganong, quoted, 33.

Garden, 12.

Gastric juice, 215, 218.

Gaye, quoted, 33, 36, 129

Geese, 3.

Geike, referred to, 30 .

Geology, 9, 14.

Geraniums, cuttings, 138.

German peasants, 206 . 
Germination, 116, 124, 133, 135.

Germs, 21, 35, 91.

Gills, 225.

Ginger, 109.

Gizzard, 220, 235.

Glaciers, 24, 35.

Glands, 210, 232.

Gluten, 213, 218, 219.

Gluten-meal, 267.

Glycogen, 211, 213, 232.

Grafting, 137, 138, 139, 144 .

Grain-feeders, 212.

Grains, 2, 109.

Grains and phosphoric acid, 93.

Graminero, 193.

Granite, wearing away, 30.

Grape districts, $27 \%$.

Grape mildew, 167 .

Grapes, cuttings, 138, 142.

Grass, 179, 189, 193.

Grass and daisies, 31.

Grass-feeders, 212.

Gravitation and growth, 122.

Green-crops, plowing under, 60, 65.

Green-manures, 21, 41, 52, 78, 79.

Growth and nitrogen, 89.

Growth, in plants, 113, 120, 121.

Growth processes, 120, 121.

Grub, white, 205.

Gypsum, 95, 105, 123.

Habltableness, 107.

Hair-waste, 204.

Half-way stone, 32 .

Happiness, 6.

Hard-pan, 67, 74.

Harrows, 69, 155, 160.

Harvesting machinery, 7 .

Hay raising, 185.

Heading-in, 166.

Heart, 225, 228, 238.
Heat and germination, 133.

Heat and plants, 119.

Heat-producing, 229, 246, 256.

Hellebore, 169.

Hemp, 109.

Herbage and plowing, 67, 68 .

Herbivorous animals, 108, 212.

Hogs. See pigs and swine.

Hoes, 69 .

Honeysuckle, layering, 142.

Hoof-meal, 20t, 206.

Hop districts, 277 .

Horn, 204.

Horse, air required by, 269.

Horse, intestine of, 212.

Horse, trotting, 275.

Horses, 3, 108, 201, 212.

Horses, food of, 212, 272.

Horses, standards for, 252.

Horticulture, 2, 3, 12.

Hortus, 12.

Host, 167, 174, 183, 197.

Housing of animals, 258, 266, 272.

Hudson, palisades of, 30 .

Humus, 20, 22, 34, 41, 51, 52, 77. $78,81,91,93,96,149,194,264$.

Hungarian grass, 193.

Hunting, 12.

Husbandry, 2, 11, 28.

Hydraulic rams, 7.

Hydrochloric acid in stomach, 218.

Hydrogen, 96.

Hydroseopic water, 48, 49.

Implements, $66,69,71,74,75,76$, $158,160,162,171$.

Indian corn. See maize.

Inorganic matter, 16, 28.

Insalivation, 216.

Insecticides, 168.

Insects, fighting, 15, 161, 166, 168. 
Intensive farming, $79,84,265$.

Internole, 121.

Inter-tillage, 64, 72.

Intestimal juice, $21 \%, 220,2 \cdot 21$.

Intestines, sizes of, 21:.

lodine, $130,233$.

Iron, 87.

Irrigation, 48,58 .

Irritability, 1:2.

lslunds, floating, 20.

Japan clover, $79,15:, 194,197$.

.Tellies, 11.

Tudging animals, 261, 273. 275.

.Tuno grass, 181, 190, 195, 197.

Jute, 109.

Kansas Experiment Station, bi:.

Kerosene and emulsion, 16s, 17.5.

King, quoted, $13,33,35,36,43,45$, $63,72,111$.

Kitchen-grarden vegetables, 3, 12.

Lagoons, 19, 2:1, 107.

Lakes snd soil, 19.

I sand detimed, 1 ti.

Landscape horticulture, 3, 109.

Law, James, chapter by, a as.

Laтก, 3. 109.

Layers, 13\%, 14:.

Leachy soils, 38, 39, 50, 91.

Leaf-blights, 174 .

Leaf-hoppers, 168.

Leares, $8 t$.

Leguminous plants, 79 , so 181, 192.

Lespedeza bicolor, 194.

Lichen, :31.

Liebig, work of, 13.

Lilnes, layering, 14:.

Lime, $45,87,97$.

Lime and phosphorus, 94.
Limo and sulfuric acid, 33

Litmus paper, $98,104,234$.

Liver, 200, 20.2.

Live-stock, $26,3$.

Loam, :20, 51 .

Locomotion, animal, $\bar{\tau}$.

Lodeman, referred to, 177 .

Loin, 273, 27t, 27\%.

London purple, 168, 176.

Longevity of seels, 133, 141.

Lubbock, quoted, 30.

Lncerne, 199.

L,umber, 1:, 109.

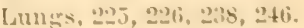

Luxuries, 5. 109.

Lymph, 211, 22:2, 23:2, 236.

Machinery, 7 .

Маize, 5, 26, 31, 47, 57, 58, 79.

Maize and live-stock, 264, 266.

Maize and oxygen, 11\%.

Maize, food in, 278.

Maize fornge, 19:.

Maize, regermination, 136.

Maize, seed-bed for, 148,152 .

Maize, tilling, 160, 170.

Ial-mutrition, 8 .

Mammals, 3.

Management of stoek, 259.

Mangrove, 19, 33.

Manufacture, 2., 11, 15.

Manures, 21, 41, 52. 65, 81, 8*, 8?. $93,201,206,265,268$.

Many-celled animals, oos.

Marble, wearing nway, 30, 32.

Market-gardening, 86, 265.

Market problems, 5 .

Marl, 83.

Marsh grasses, 19.

Mateh, 104.

Mathematics, 15 
Meadows, harrowing, 160.

Meadows, making, 185.

Meal for feeding, 267.

Meat, 5, 202.

Meat, dried, 206.

Mechanics, 7.

Medicine, 2, 8 .

Medicines, 109.

Nellow soils, 38, 39.

Melon and cold, 120.

Merrill, referred to, 36 .

Meteorology, 9.

Mlicrobe, 35.

Micro-organisms, 22, 34.

Micro-organisms and ferment, $2: 32$.

Micro organisms and nitrogen, 91.

Milch cow, care of, 230.

Mildews, 167, 174.

Milk, 1.

Milk-curdling ferment, 218, 221.

Milk machinery, 7 .

Milk secreted, 211.

Mining, 12.

Mixed husbandry, 11, 28, 279.

Moisture and germination, 133, 141 .

Moisture, conservation, 56, 65, 71 .

Moisture in soils, 38,47 .

Mold, 20, 51.

Molds, 173.

Molecules, 32.

Monocalcic phosphate, 95 .

Monuments, wearing away, 30 .

Moss, 31, 33.

Mountains, 16, 29.

Muck, 83.

Mulch of soil, $57,65,69,71,149$.

Muley, 262.

Mullein, 36.

Muriate of potash, 96, 123.

Muriatic acid in stomach, 218.

Muscle cell, 231
Mustard, 79.

Muzzle, 273, 276, 277.

Nebraska Experiment Station, 63.

Nervous processes, 210.

Nicholson, quoted, 14.

Nile, 24.

Nitrate of soda, $90,92$.

Nitrates, 90, 91, 104.

Nitrification, $38,65,91$.

Nitrites, 104.

Nitrogen, 87, 89, 98, 101, 116, 203.

Nitrogen, amount in soil, 25.

Nitrogen-gatherers, 79, 80, 181, 192.

Nitrogen in food, 213, 245.

Numbers of species, 14.

Nurserymen's moss, 33.

Nutrition in cells, 210.

Nutritive ratio, 247, 257.

Oats, 47,79 .

Oats for forage, 193.

Oats, regermination, 136.

Oats, water in, 47 .

Offices of the plant, 106.

Oil-meal, 267.

Oil of vitriol, 92, 94.

Olericulture, 3.

Onion seeds, 133, 136.

Opium, 109.

Optimum temperature, 119, 134.

Orange, buclding, 144.

Oranges, 108.

[197.

Orchard-grass, $110,181,190,196$,

Orchards, tilling, 161. [66.

Organic matter, 16, 19, 28, 33, 34,

Organic matter removed by burn-

Organisms, 21.

[ing, 29.

Ornamental plants, 3, 109.

Ornithology, 8, 15.

Osmosis, 113. 
Ostreaculture, 3.

Ox, 212.

Oxen, standards for, 252.

Oxygen, 90, 116, 129.

Oxygen and germination, 133, 134.

Oxygen in blood, 211, 223, 246.

Oxygen in breathing, 224.

Oyster-raising, 3.

Palatability, 244, 254.

Palisades, 30.

Pancreatic juice, 215, 221.

Paradise, 12.

Parasitic fungi, 166, 173.

Paris green, 168, 176.

Parkinson's book, 13.

Parsnip seeds, 133.

Particles of soil, size of, $39,43,44$.

Pastures, harrowing. 160, 181.

Pastures, permanent, 180, 197.

Pathology, 8.

Pea family, 79.

Pea mildew, 167.

Pea, regermination, 136.

Peach, budding, 144.

Peaches, 106.

Pear-blight, 167.

Pear, propagating, 144.

Pears, tilling, 162.

Peas, 92, 193.

Peas, to prevent erosion, 51.

Peat, 20, 83.

Pedigree, 262, 263, 278.

Pepsin, 218.

Peptones, 219, 223.

Perennials, 146.

Perfumery, 109.

Pests, 10, 167.

Pests and stock, 205.

Pets, 204.

Phleum pratense, 195.
I'hospluate, 88, 94, 95, 104.

Phosphatic rocks, 94.

Phosphoric acid, 25, 93, 98, 101.

Phosphorus, 87, 88, 104, 116, 203.

Physics, 6.

$[170,174$.

Physiological troubles, 166, 167,

Physiology, 8.

Pigs. See also swine.

Pigs, standards for, 252.

Pin-bone, 273, 276, 278.

Planker, 71, 75, 76.

Plant-food defined, 128.

Plant-food elements, 87.

Plant, how it lives, 112.

Plant-knowledge, 7.

Plant-lice, 166, 168.

Plants, species and rarieties, 14 .

Plaster, 95.

Plowing, 66, 162, 171.

Plowing green-crops, 60, 65.

Plowing to dry the land, 68.

Plows, 73, 74.

Plum, budding, 144.

Plum-rot, 175.

Poa pratensis, 195.

Points of animals, 26., 273, 275.

Poisons for insects, 168.

Pomace, 84, 256.

Pomology, 3.

Ponds and soil, 19.

Pork. 203.

Pot, with plant, 46.

Potash, 95, 98, 101.

Potash, amount in soil, 25.

Potassium, 87, 104, 116.

Potato-bugs, 169.

Potato mildew, 167.

Potato, propagation, 146, 155.

Potato refuse, 78.

Potato, seed-bed for, 154, 15.5.

Potato tuber, 121. 
Potato, varieties of, 14 .

Potatoes, 1, 96, 108.

Potatoes and muriate, 96.

Potatoes, tilling, 160.

Potatoes, water in, 47.

Potential plant-food, 36.

Poultry, breeds of, 260.

Poultry-raising, 3, 203.

Prairies, stock on, 266.

Preeipices, 30.

Precipitate, 235.

Precipitation, 59.

Prepotent, 261.

Preventives for pests, 167.

Principles, 15.

Principles of pruning, 165.

Propagation of plants, 13:.

Prophylaxis, 175.

Proteids, 247, 248.

Protein, 243, 244, 248.

Protoplasm, 113, 127.

Proventriculus, 220, 235.

Pruning, 163.

Ptomaines, 224, 236.

Ptyalin, 216, 233.

Puddling, 68.

Pump, 7, 169, 170, 177.

Pumpkin, germination, 124.

Pure-blood stock, 263.

Purse, 278.

Quack-grass, 31.

Quadrupeds, 201.

Quantity of food, 250, 258, 266.

Quarries, 30.

Quarter, 273.

Quick-lime, 40, 97.

Quixce, propagation, 144.

Quinces, 109.

Quinine, 109.

Rabbits, 204.
Ragweed, 31.

Rain drops, 35.

Rainfall, 48, 50, 59, 63, 107.

Rakes, 69.

Range, 263.

Rape, 79.

Ratio, nutritive, 247, 357 .

Ration, 214, 250, 271.

Red-clover is tap-rooted, 146,147

Red-top, 181, 190.

Refuse, 78.

Regermination, 136.

Remedies for pests, $16 \pi$.

Rennet, 235.

Reservoir for water, 54, 6:3, 67 .

Resources of soil, 25.

Respiration in animals, 224.

Respiration in plants, 117.

Rest of animals, 228 .

Resting the land, 80 .

Retentive soils, 38, 39.

Reverted phosphate, 95.

Ribs, 273.

Rice, 108.

Rill, 35.

$[179,259$.

Roberts, I. P., chapters by, 145,

Roberts, quoted, 25, 35, 36, 45, 63, $72,74,76,84,86,105,207$.

Rock and soil, 16, 42.

Roller, 71, 76, 155.

Root crops, 96.

Root, evolution of, 31 .

Root, growth of, 121, 131.

Root-hairs, 113, 124.

Root-pressure, 115, 125.

Root-pruning, $165 . \quad[32,88,104$.

Roots and soil formation, 16. 21.

Rose-bug, 175.

Rot of plum, 175.

Rotation, 79, 179, 197, 207.

Rotation and pests, 168. 
Rotten stones, 23.

Roughage, 191.

Ruminants, 216, 253.

Rump, 273, 274, 278.

Rusts, 174.

Rye and pastures, 181.

Rye for forage, 192.

Rye to plow under, 67, 79.

Rye, to prevent erosion, 51.

Saliva, 215, 232.

Saltpetre, 90.

Salts, 115, 123, 214.

Sand-bars, 35.

Sand, moisture in, 51.

Sand-storms, 25.

Sands held by plants, 111 .

Sap, 114, 115, 124, 126, 131.

Saprophyte, 173.

Sawdust, 83.

Scab, 167.

Scale insects, 166, 168.

Scales, experiment with, 59.

Sciences, 5.

Sea crabs, 206.

Sea margins, 19.

Seaweed, 31.

Sea-wrack, 19.

Season to prune, 164.

Secretion, 210.

Sedges, 19, 193.

Seed, 155.

Seedage, 133, 135.

Seed-bed, 70, i1, 134, 145, 155.

Seedlings, raising of, 135 .

Seeds, germination, 133, 142, 145.

Semi-etaples, 108.

Shade, 108.

Shaler, referred to, 36 .

Sheep, 3, 108, 201, 212.

Sheep stomach, 233.
Sheltering manure, 82 .

Ships dusty at sea, 36 .

Shower, 35.

Silage, 254, 258.

Silicon, 87.

Silo, 258, 265.

Single-celled animals, 208.

Slips, 138.

Smuts, 170, 178.

Snowballs, layering, 140 .

Soaking seeds, 134.

Soap washes, 168.

Sod, influence on soil, 21, 68.

Sod in orchards, 161.

Sodium, 116.

Soil and stock, 202.

Soil, contents of, 16,42 .

Soil, moisture in, 50 .

Soil-mulch, 57, 65, 69, 71, 149.

Soil particles, size of, $39,43,44$.

Soil, texture of, 37.

Soiling crops, 191.

Sorauer, referred to, 124, 126, 127.

Specialized, 232.

Specialty-farming, 11, 279.

Species, number of in cultivation,

Speculation, 12. [by, 37.

Spencer, J. W., quoted 35; chapter

Sphagnum, 20, 33.

Spices, 109.

Spittle, 232.

Spores, 169, 218, 234.

Sport, 262.

Spraying, 165, 169.

Springs, 48, 50.

Squash-bug, 167.

Squash, seedling of, 131 .

Squashes and moisture, 57.

Stable-manure, 21, 41.

Stable-manures, 65, 81, 82, 89, 93, 201, 265, 268. 
Stables, 82, 86, 258, 269, 272.

Standards, feeding, 252.

Staples, 5, 108.

Starch, 28, 118, 127, 129, 130, 233.

Starch equivalent, 247.

Starch in food, 213, 246.

Steer, score of, 277.

Stem, growth of, 121, 130.

Stifle, 273.

Stink-bug, 167.

Stock, 3, 201.

Stock and pastures, 181.

Stock, care of, 259.

Stock, in grafting, 139 .

Stockbridge, referred to, 36 .

Stomach, 212, 233.

Stomata, 114, 117, 124.

Stones grow smaller, 30.

Stones, rotten, 23.

Stratification, 136.

Straw, 83.

Streams, action of, 35 .

Streams carry soil, 23.

Struggle for existence in tree-top, $163,173$.

Stubble and plowing, 68 .

Stubble refuse, 78,80 .

Sturterant, quoted, 14.

Subsoil, 74.

Subsoiling, 68.

Subsurface, 155.

Sulfate of ammonia, 92.

Sulfate of potash, 96 .

Sulfur, 87, 116.

Sulfur fungicide, 169.

Sulfuric acid, 33, 92, 94, 95.

Sugar, 28.

Sugar-beet, 147.

Sugar-cane and muriate, 96, 146.

Sugar in plant, 120, 127, 131.

Sugar in digestion, 223.
Sugars in food, $213,246$.

Summer-fallowing, 158.

Sunlight and growth, 118.

Superphosphate, 104.

Surgery, 8.

Swamps, 20.

Sweat, 211.

Sweet potatoes, 148.

Sweet vernal grass, 191.

Swine, 201.

Swine and pests, 205.

Swine, feeding, 272.

Switch, 273.

Symbols of elements, 103.

Syringe, 169.

Tankage, 203, 206.

Tap-roots, 110, 147.

Tarr, referred to, 14, 35, 36 .

Teats, 273, 276.

Temperature for barns, 270.

Temperature for germination, 134.

Temperature of soil, 38.

Texas steer, 212.

Textiles, 109.

Texture of soil, 31 .

Thawing, influence on soils, 68 .

Thinning, 166.

Threshers, 7.

Thrips, 168.

Thurl, 273, 276, 278.

Tillage and water capacity, 54, 63 .

Tillage defined, 64, 72 .

Tillage of the soil, 64, 159.

Timber, 2, 3, 109.

Timothy for meadows, 186, 189, 199.

Timothy, picture of, 195, 196.

Toadstools, 173.

Tobace and muriate, 96.

Tobacco insecticide, 168.

Tomatoes, 106. 
Tools, 66, 6!, 71, 74, 75, 76, 158, Toxins, 22t, $236 . \quad[160,162,171$. Training, 163.

Transpiration, 114, 120, 125.

Transportation, 11, 15.

Transportation of soils, 2.2.

Tricalcic phosphate, 94.

Trifolium hybridum, inearuatum, medium, pratense, repens, 193,

Trimming, 163.

[194.

Tropical plants, 119.

'Trypsin, 221.

Tull, Jethro, 44, 72.

'Turgidity, 113, 127.

'I'urkeys, 3, 201.

Udder, 273, 276.

Underdrainage, 40, 53, 60.

Valleys, 16.

Vegetables, 3, 11, 109.

Ventilation, 228, 269.

Viability, 133.

Vilmorin, quoted, 14.

Villus, 222, 235, 236.

Vineyards and rose-bugs, 175.

Vitality of seeds, 133.

Vitriol, oil of, 92, 94.

$[206$.

Voorhees, referred to, 84, 86, 105 ,

Waste in animals, 228, 229.

Water, amount soil will hold, 47, 59.

Water, driving off by heat, 29 .

Water for stock, 271.

Water in foods, 243.

Water in the plant, 113, 114.

Water-lily, 19.

Water moves lands, 23.

WVater plants, 19.

Water-sprouts, 165.
Water-table, $40,46$.

Water used by plants, 63, 74 .

Weather, 9, 10.

Weathering, 16, 30 .

Weeds, 69, 70, 76, 81, 159, 160, 170,

Weeds and stock, 205.

$[179$.

Weeds, kinds, 15.

Weevils, 175.

Weight of water on acre, 63.

Wells, 48.

Wheat, 1, 4, 26, 108, 198.

Wheat and mullein, 36 .

Wheat and pastures, 181.

Wheat, germination, 124, 136.

Wheat, propagation, 132.

Wheat, seed-bed for, 148, 152, 155,

Wheat, tilling, 160.

[158.

Wheeler, referred to, 45 .

White hellebore, 169.

Willow, 31, 146.

Windbreaks, 107, 111.

IVindmills, 7 .

Winds and soils, 24.

Wine, 11, 109.

Wing, H. H., chapter by, 240.

Wing, H. H., referred to, 378.

Wiscousin, University of, 13, 277.

Wither's, 273, 276.

Wolves, 212.

TVood or timber, 2, 3.

Wood products, 109.

WVool, 1.

Wool-waste, 204.

Work of animals, 228.

Worms, 166, 169.

Worn-out lands, 21.

Wounds, healing, 163, 164.

Zoölogy, 8. 


\title{
CYCLOPEDIA OF AMERICAN AGRICULTURE
}

\author{
Edited by L. H. BAILEY
}

Of Cornell University, Editor of "Cyclopedia of American Horticulture," Author of "Plant Breeding," "Principles of Agriculture," etc.

WITH 100 FULL-PAGE PLATES AND MORE THAN 2,000 ILLUS-

TRATIONS IN THE TEXT-FOUR VOLUMES-THE SET :

CLOTH, \$2O NET-HALF-MOROCCO,\$32 NET-CARRIAGE EXTRA

\section{Volume I-Farms}

The Agricultural Regions-The Projecting of a Farm-The Soil Environment-The Atmosphere Environment.

\section{Volume II-Crops}

The Plant and Its Relations-The Manufacture of Crop ProductsNorth Americun Field Crops.

\section{Volume III-Animals}

The Animal and Its Relations-The Mannfacture of Animal Produets-North American Furm Animals.

\section{Volume IV-The Farm and the Community}

Economics-Social Questions-Organizations-History-Literature, etc.

"Indispensable to public and reference libraries . . readily comprebensible to any person of average edueation." -The Nation.

"The completest existing thesaurus of up-to-date facts and opinions on modern agricultural methods. It is safe to say that many years must pass before it can be surpassed in comprehensiveness, accuracy. practical valne, and mechanical excellenre. It ought to be in every library in the country.

- Kecord Herald, Chieago.

\section{Published by \\ THE MACMILLAN COMPANY}




\section{BOOKS ON AGRICULTURE}

On Selection of Land, etc.

Thomas F. Hunt's How to Choose a Farm . . . \$1 75 net

E. W. Hilgard's Soils : Their Formation, and Rela-

tions to Climate and Plant Growth .... 400 net Isaac P. Roberts' The Farmstead . . . . . 150 net

On Tillage, Crops, etc.

F. H. King's The Soil . . . . . . . 150 net

Isaac P. Roberts' The Fertility of the Land . . . 150 net

Elwood Mead's Irrigation Institutions . . . . . 125 net

F. H. King's Irrigation and Drainage ...... 150 net

Wm. E. Smythe's The Conquest of Arid America . . 150 net

Edward B. Voorhees' Fertilizers . . . . . . . 125 net

Edward B. Voorhees' Forage Crops ..... . . 150 net

H. Snyder's Chemistry of Plant and Animal Life . . 125 net

H. Snyder's Soils and Fertilizers. Third edition . . 125 net,

L. H. Bailey's Principles of Agriculture . . . . . . $125 \mathrm{ne}^{4}$

W. C. Welborn's Elements of Agriculture; Southern and Western............ 75 net

J. F. Duggar's Agriculture for Southern Schools . . 75 net

On Plant Diseases, etc.

George Massee's Plant Diseases. . . . . . 160 net

J. G. Lipman's Bacteria in Relation to Country Life . 150 net

E. C. Lodeman's The Spraying of Plants . . . . 125 het

H. M. Ward's Disease in Plants (English) . . . . 160 net

A. S. Packard's A 'Text-book on Entomology ... . 450 net

00 Production of New Plants

L. H. Bailey's Plant-Breeding . . . . . . 125 net

L. H. Bailey's The Survival of the Unlike . . . 200 net

L. H. Bailey's The Evolution of our Native Fruits . 200 net

W. S. Harwood's New Creations in Plant Life . . . 175 net

On Garden Making

L. H. Bailey's Practical Garden-Book ...... 100 net

L. H Bailey's Garden-Making ........ 150 net

L. H. Bailey's Vegetable-Gardering ....... 150 net

L. H. Bailey's Horticulturist's Rule Book ..... 75 net

L. H. Bailey's Forcing-Book ......... 125 net

A. French's Book of Vegetables ........ 175 net 


\section{BOOKS ON AGRICULTURE, continued}

On Fruit-growing, etc.

L. H. Bailey's Nursery-Book ........\$1 50 net

L. H. Bailey's Fruit-growing ......... 150 net

L. H. Bailey's The Pruning-Book ....... 150 net

F. W. Card's Bush Fruits ......... 150 net

On the Care of Live Stock

Nelson S. Mayo's The Diseases of Animals . . . 150 net W. H. Jordan's The Feeding of Animals ..... 150 net

I. P. Roberts' The Horse .......... 125 net

George C. Watson's Farm Poultry ........ 125 net

\section{On Dairy Work}

Henry H. Wing's Milk and Its Products ..... 150 net

C. M. Aikman's Milk . . . . . . . . . 125 net

Harry Snyder's Dairy Chemistry ....... 100 net

W. D. Frost's Laboratory Guide in Elementary

Bacteriology .... ...... 160 net

I. P. Sheldon's The Farm and the Dairy..... 100 net

On Economics and Organization

L. H. Bailey's The State and the Farmer . . . . 125 net

Henry C. Taylor's Agricultural Economies . . . . 125 net

I. P. Roberts' The Farmer's Business Handbook . . 125 net

George T. Fairchild's Rural Wealth and Welfare.. 125 net

S. E. Sparling's Business Organization...... 125 net

In the Citizen's Library. Includes a chapter on Farming.

Kate V.St. Maur's A Self-Supporting Home . . 175 net

Kate V. St. Maur's The Earth's Bounty ....... 175 net

On Everything Agricultural

L. II. Bailey's Cyclopedia of American Agriculture:

Vol. 1. Farms, Climates, and Soils.

Vol. II. Farm Crops.

Vol. III. Farm Animals.

Vol. IV. The Farm and the Community.

Price of sets: Cloth, $\$ 20$ net; half-moroceo, $\$ 32$ net.

For further information as to any of the above, address the publishers

THE MACMILLAN COMPANY

64-66 Fifth Avenue

NEW YORK 


\section{By HARRY SNYDER, B.S.}

Prolessor of Agricultural Chemistry, University of Minnesota, and Chemise of the Minnesota Agricultural Experiment Station

\section{The Chemistry of Plant and Animal Life}

llustrated. Cloth. $12 \mathrm{mo}$. 406 pages. $\$ 1.25$; by mail, $\$ 1.35$.

"The language is, as it should be, plain and simple, free from all needless technicality, and the story thus told is of absorbing interest to every one, man or woman, hoy or girl, who takes an intelligent interest in farm life." - The New England Farmer.

"Although the book is highly technical, it is put in popular form and made eomprehensible from the standpoint of the farmer: it deals largely with those questions which arise in his experience, and will prove an invaluable aid in countless directions."-The Farmer's Voice.

\section{Dairy Chemistry}

Illustrated. 190 pages. $\$ 1$ net; by mail, $\$ 1.10$. "The book is a valuble one which any duiry farmer, or, indeed, any one handling stock, man read with probit."-Kural New Yorker.

\section{Soils and Fertilizers}

Third Edition. lllustrated. $\$ 1.25$ net; by mail, $\$ 1.38$

A book which presents in a concise form the principles of soil fer. tility and discusses all of the topies relating to soils as outlined by the Committee on Methods of 'leaching Agriculture. It contains 350 pages, with illustrations, and treats of a great variety of subjects, such as Physical Properties of Soils; Geological Formation, etc.: Nitrogen of the Soil and Air; Farm Manures: Commereial Fiertilizers, several chapters; Rotation of Crops; Prepuration of Soil for Crops, etc.

\section{THE MACMILLAN COMPANY}







\section{LIBRARY OF CONGRESS}

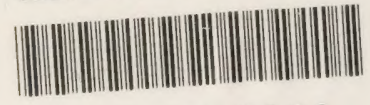
00027733116 